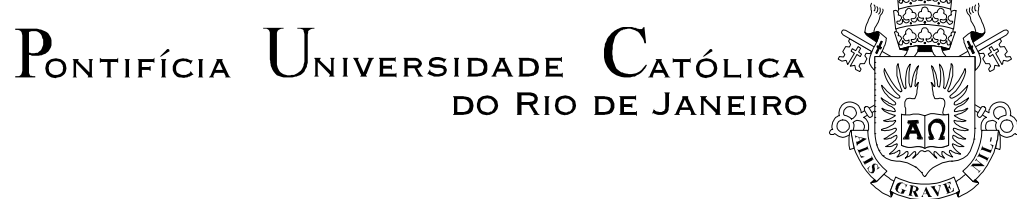

Carla Mirelle de Oliveira Matos Lisboa

O TRABALHO VOLUNTÁRIO DE REINSERÇÃO SOCIAL JUNTO A PESSOAS EM SITUAÇÃO DE RUA: Um estudo sob a perspectiva da Análise da Conversa

\title{
Tese de Doutorado
}

Tese apresentada ao Programa de Pós-graduação em Estudos da Linguagem do Departamento de Letras da PUC-Rio como requisito parcial para obtenção do grau de Doutora em Letras.

Orientadora: Profa. Maria do Carmo Leite de Oliveira

Coorientador: Michel Gustave Joseph Binet

Rio de Janeiro

Junho de 2019 


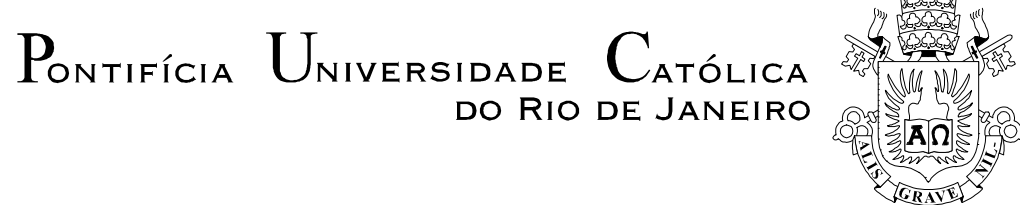

\title{
Carla Mirelle de Oliveira Matos Lisboa
}

O trabalho voluntário de reinserção social junto a pessoas em situação de rua: um estudo sob a perspectiva da Análise da Conversa

Tese apresentada como requisito parcial para obtenção do grau de Doutora pelo Programa de Pós-graduação em Estudos da Linguagem da PUC-Rio. Aprovada pela Comissão Examinadora abaixo.

\author{
Profa. Maria do Carmo Leite de Oliveira \\ Orientadora e presidente \\ Departamento de Letras- PUC-Rio
}
Prof. Michel Gustave Joseph Binet Coorientador Universidade Lusíada de Lisboa - ULL

Profa. Liana de Andrade Biar Departamento de Letras - PUC-Rio

Profa. Maria da Graças Dias Pereira Departamento de Letras - PUC-Rio

Prof. Paulo Cortes Gago Universidade Federal do Rio de Janeiro - UFRJ

Profa. Maria Isabel de Jesus Sousa Universidade Lusíada de Lisboa - ULL

Rio de Janeiro, 18 de junho de 2019. 
Todos os direitos reservados. É proibida a reprodução total ou parcial do trabalho sem autorização da universidade, da autora e da orientadora.

\section{Carla Mirelle de Oliveira Matos Lisboa}

Graduou-se em Letras Português pela Universidade Federal de Sergipe (UFS), em 2011. Tornou-se Mestra em Estudos de Linguagem pela Universidade Federal Fluminense (UFF), onde foi bolsista nota 10 da FAPERJ (Fundação Carlos Chagas Filho de Amparo à Pesquisa do Estado do Rio de Janeiro), em 2015.

Ficha

Catalográfica

Matos Lisboa, Carla Mirelle de Oliveira

O trabalho voluntário de reinserção social junto a pessoas em situação de rua : um estudo sob a perspectiva da análise da conversa / Carla Mirelle de Oliveira Matos Lisboa ; orientadora: Maria do Carmo Leite de Oliveira ; co-orientador: Michel Gustave Joseph Binet. - 2019.

$173 \mathrm{f.} ; 30 \mathrm{~cm}$

Tese (doutorado)-Pontifícia Universidade Católica do Rio de Janeiro, Departamento de Letras, 2019.

Inclui bibliografia

1. Letras - Teses. 2. Trabalho voluntário. 3. Oferta. 4. Interação. 5. Pessoas em situação de rua. 6. Análise da conversa. I. Oliveira, Maria do Carmo Leite de. II. Binet, Michel. III. Pontifícia Universidade Católica do Rio de Janeiro. Departamento de Letras. IV. Título. 
A todas as pessoas que (sobre)vivem ou (sobre)viveram em situação de rua. 


\section{Agradecimentos}

Registro, aqui, meus sinceros agradecimentos:

A Deus, por ser minha Luz maior, por ser a fonte da minha crença de que, com força, foco e fé, conseguiria concluir essa etapa da minha vida com êxito. Por cuidar tão bem de mim, em todos os momentos da minha vida, bons e ruins. Inclusive, colocando pessoas muito especiais em meu caminho, as quais tornaram a minha trajetória mais leve e agradável, e serão, por isso, destacadas a seguir.

A Carmo, por ser a melhor orientadora que eu poderia ter! Sua intuição certeira me ajudou a ver caminhos que, até então, não haviam sido observados por mim, muito devido à minha total imersão na realidade do tema abordado na tese. Agradeço por toda a confiança, amor, respeito, paciência, carinho e por aguentar minhas angústias e ansiedades. O doutorado foi muito (lê-se muito!) desgastante. Mas, nos momentos em que eu estava com minha saúde emocional mais fragilizada, a Carmo teve todo o cuidado em me passar a tranquilidade e a segurança de que eu precisava para seguir em frente. Atitudes de uma boa mãe. Afinal, como dizemos no Grupo de Pesquisa: ela é nossa mãe acadêmica! Suas ações ultrapassam às de orientadora da pesquisa; ela assume várias outras comuns às das nossas mães. Ainda, por ser uma pesquisadora excepcional, sempre preocupada com o retorno social de nossas pesquisas! Meu enorme e sincero agradecimento por TUDO!

A Michel Binet, por ter aceitado ser coorientador desta tese. Por nossas ricas sessões de análise conjunta de dados que potencializaram profundamente o meu interesse pelo campo do Serviço Social, a qualidade do meu estágio doutoral e por todas as suas contribuições, que foram muito importantes para minha formação e para esta tese. Sempre acolhedor, solícito, com uma ótima intuição de analista da conversa e disposto a compartilhar seus conhecimentos e amizade.

À professora Ana Cristina Ostermann, pelas sugestões/orientações preciosas durante a qualificação, bem como em outros momentos do doutorado, pelo carinho e atenção a cada encontro virtual ou físico. 
Às professoras e ao professor, integrantes da banca de defesa, pela leitura atenta, pelas produtivas críticas, reflexões e sugestões de melhoramento.

À professora Liana Biar, pelos cursos e debates maravilhosos, pelas ricas contribuições na qualificação, durante as disciplinas que tive a alegria de cursar, pelo afeto e atenção de sempre.

À professora Maria das Graças Dias Pereira, por toda sua generosidade, pelas referências indicadas, pela acolhida única e calorosa quando eu cheguei à PUC e por todas as contribuições.

Ao professor Paulo Gago, por ter me permitido participar de seu curso de Introdução à Análise da Conversa (AC), na UFRJ. Agradeço, ainda, pelas ótimas contribuições para o melhoramento desta tese.

À professora Isabel de Souza, por ter me indicado a Comunidade vida e paz, em Lisboa, pela acolhida, carinho e pelas ricas contribuições para esse trabalho.

Às maravilhosas professoras do Programa de Pós-Graduação em Estudos da Linguagem da PUC-Rio, pelos ensinamentos e pelas discussões proporcionadas em suas aulas ou nos eventos, em especial Liliana Bastos, Adriana Nóbrega e Erica Rodrigues.

À mulher da minha vida, minha mãe, Joseni, por seu amor incondicional, por me apoiar em todos os meus sonhos e ser minha companheira de vida, sempre disposta a aprender e a ensinar. Gratidão pelo amor, por todas as orações, por toda reciprocidade em nossa relação, por cada leitura atenta dos meus textos; por enfrentar seus medos, para que eu seja forte e também enfrente os meus; por se fazer sempre presente, independentemente da distância geográfica.

Ao meu esposo, Lucivanio, por ser o melhor companheiro de vida que eu poderia ter! Por evoluirmos e amadurecermos juntos, fortalecendo o nosso amor e a nossa cumplicidade. Por ler textos escritos por mim, sempre apresentando seu ponto de vista sobre eles, por me ouvir e contribuir para que eu pudesse lidar melhor com os problemas da tese e da vida. Por (não sei como) conseguirmos revezar entre estarmos fortes e frágeis, um para o outro, nos momentos mais delicados de nossa trajetória, conseguindo estabelecer um equilíbrio que nos faz tão bem.

A toda minha família, pelas orações e torcida, em especial, aos meus amados irmãos, Marcos Alberto e Júlio Cézar, por entenderem as minhas ausências físicas, torcerem sempre por mim, apoiando os meus sonhos e se fazendo presentes, independente da distância. Às minhas cunhadas, Mônica, Fabiana e Lucivânia, pelo carinho e pela torcida. Fabiana, sempre disposta a ler e revisar alguns de meus textos, inclusive capítulos da tese. 
Aos/às queridos/as sobrinhos/a e afilhado/as Erick, Mayrla, Marlyssom, Kauãn, Igor Victor, Joice, Eloísa, Mariana, por serem luz e amor em minha vida! A Victor, pela tradução do resumo.

Ao meu pai, João Araújo, pela torcida, pelas orações e pelo carinho!

À tia Evaldina e ao tio Tonho, meus segundos pais, pelas orações, pela torcida e pelo apoio, de sempre!

Aos/às amigos/as, por compreenderem as minhas ausências, pela torcida e por tornarem cada momento compartilhado único, sejam os bons ou os mais difíceis em que era/é preciso resistência e luta, em especial, Liliane Mello (Lili), Milene Leite, Nícolas, Cecília Heredia, Manolo Rodriguez, Aldi Nestor, Cléa, Makson, Fabíula Abreu, Caroline Mori, Tamires, Nancy, Rodrigo, Jaqueline e Juciara.

À Milene Leite, ainda, pela revisão final do texto e pela formatação desta tese, feitas com tanto carinho.

Aos/às colegas de curso da PUC-Rio, em especial a Naomi, Cláudia, Diego, Mayara, Renata e Glauber, pela amizade, pelos debates, conversas e pelos materiais e momentos compartilhados.

Aos queridos/as amigos/as do grupo de pesquisa DIPP: Rony Ron-Rén, Carolina Valente, Amanda Dinucci, Amanda Costa e Carlos Alves, por serem MA-RA-VILHO-SOS/AS, generosos/as, sempre dispostos/as a compartilhar conhecimento, afeto e uma boa comida. Cada um/a ao seu modo se tornou muito importante, melhor grupo de pesquisa da vida! Rony, em especial, teve que me aguentar mesmo quando eu estava no PDSE. Não sei o que seria de mim sem nossa troca de mensagens constante, querido.

À querida Cristiane Cavalcante, pelas constantes trocas de materiais sobre a população em situação de rua, de conhecimentos e de afeto.

Aos/às funcionários/as da PUC-Rio, pela atenção e pelos excelentes serviços prestados, em especial à super Chiquinha, sempre atenta, prestativa, solícita e gentil!

Aos/às amigos/as, pós-graduandos do GEACC: Victor Braga, David Monteiro, Cristina Coelho e Tânia Pinto pelas contribuições nas análises conjuntas dos meus dados e por tornarem minha estadia em Lisboa mais proveitosa e feliz.

Às amigas que tornaram a trajetória do PDSE ainda mais feliz, em especial à Lili (Liliane de Oliveira), Rosa Margarida e Mônica Baêta, que se tornaram grandes amigas e parceiras, por todos os momentos maravilhosos e únicos que compartilhamos.

Aos/às assistidos/as da TSN, pessoas queridas, que gentilmente aceitaram fazer parte da minha pesquisa e, sem as quais, esse trabalho não seria possível. Espero 
ter conseguido, ao menos um pouco, transformar suas histórias em matéria-prima que possa ser usada em favor de vocês.

Às/aos crianças/adolescentes amadas/os da Roda de Leitura TSN e suas responsáveis, por tornarem os meus sábados únicos, mais alegres e valiosos. Como também a todos/as os/as voluntários/as da Roda, pela dedicação, troca de energia, amor envolvido e sonhos compartilhados.

À Turma da Sopa de Niterói (TSN) por me acolher e se tornar minha família em Niterói À diretoria da TSN, por ter recebido com entusiasmo a proposta dessa pesquisa e por ter apoiado todo seu desenvolvimento. Como representante dessa direção, agradeço à nossa querida dona Geralda Rodrigues, ser de luz e sabedoria, que transmite paz, compartilha sonhos e me ensina muito, sempre. Do mesmo modo, aos/às amigos/as voluntários/as queridos/as de todas as equipes, pela amizade. Em especial, aos membros da equipe de Abordagem Social, por aceitarem fazer parte da pesquisa e estarem sempre dispostos/as a contribuir para a realização deste trabalho.

À Comunidade Vida e Paz, ONG de Lisboa, seus/suas assistidos/as e amigos/as voluntários/as, que me acolheram e estiveram sempre dispostos/as a compartilhar experiências e conhecimentos.

À Coordenação de Aperfeiçoamento de Pessoal de Nível Superior (CAPES), pelo apoio financeiro, tanto no Brasil quanto no exterior, PDSE/CAPES:88881.133011/2016-01(Migrado- SICAPES3), sem o qual não seria possível a concretização deste estudo. 


\section{Resumo}

Lisboa, Carla Mirelle de Oliveira Matos; Oliveira, Maria do Carmo Leite. $O$ trabalho voluntário de reinserção social junto a pessoas em situação de rua: um estudo sob a perspectiva da Análise da Conversa. Rio de Janeiro, 2019. 173 p. Tese de doutorado - Departamento de Letras, Pontifícia Universidade Católica do Rio de Janeiro.

Os estudos da prática de assistência social têm tido como foco a ação dos profissionais da área de Serviço Social. No entanto, especialmente a partir da segunda metade dos anos 70, com a entrada do terceiro setor, a luta para diminuir as desigualdades sociais abriu espaço para o trabalho voluntário do/a cidadão/ã no atendimento àqueles que vivem em condições de vulnerabilidade social. No intuito de preencher essa lacuna, este estudo tem por objetivo contribuir para o entendimento das práticas de ofertas de ajuda, realizadas por voluntários. Para tanto, são analisadas, à luz do aparato teórico-metodológico da Análise da Conversa (Sacks, 1992; Sacks; Schegloff; Jefferson, 1974), as interações entre voluntários/as da Equipe de Abordagem Social da Turma da Sopa de Niterói, que tem como objetivo institucional tentar contribuir para o processo de reinserção/reintegração social de pessoas em situação de rua ou vulnerabilidade social, atendidas por eles/elas. Os resultados revelam a organização estrutural global das interações que constituem a abordagem social, identificando as etapas desse trabalho (início da abordagem, escuta e/ou sondagem, condução propositiva e fechamento), bem como as (micro) ações que ocorrem em cada fase. A pesquisa aponta também para a centralidade das ofertas nas conduções propositivas, diferenciando as ofertas delicadas, que apresentam formato despreferido, das não-deliciadas, realizadas em formato preferido. Com base nas análises, é possível identificar que práticas se mostraram mais ou menos eficazes para o atingimento dos objetivos institucionais.

\section{Palavras-chave}

Trabalho voluntário; oferta; interação; pessoas em situação de rua; Análise da Conversa. 


\section{Abstract}

Lisboa, Carla Mirelle de Oliveira Matos; Oliveira; Oliveira, Maria do Carmo Leite (Advisor). The volunteer work of social reintegration of people experiencing homelessness: a study through the conversation analysis perspective. Rio de Janeiro, 2019. 173 p. Tese de doutorado - Departamento de Letras, Pontifícia Universidade Católica do Rio de Janeiro.

The study of professional practice in the field of social work focuses on the action of those trained in social services. However, particularly from the second half of the 1970s, along side the emergence of the third sector, the struggle for social care provision has opened up the possibility for citizens to engage in community service projects by supporting those who are socially vulnerable. Intending to fulfill this gap, this study focus is contributing to improving the comprehension of social reintegration practices performed by volunteers. In order to do so, the interaction between volunteers from the Social Approach Group of the Soup Group of Niterói and people experiencing homelessness was analyzed through the theoretical-methodological approach of Conversation Analysis. The results reveal the overall structural organization of the interaction, identifying the steps of this work (beginning of the approach, probing, propositional conduction, and closure) as well as the (micro) actions that occur in each step. The research also points to the centralization of the offers in propositional conductions, separating the delicate offers, which present unpreferred format, from the non-delicate ones, which are performed in a preferred format. Based on the analysis, it is possible to identify some practices that are more or less effective to achieve the interactional goals.

\section{Keywords}

Voluntary work; offer; interaction; people experiencing homelessness; Conversation Analysis. 


\section{Sumário}

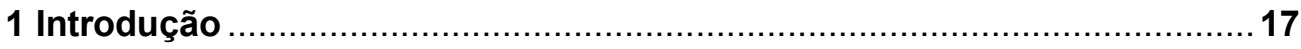

1.1. A construção da questão de pesquisa .......................................... 22

1.2. Objetivos e relevância da pesquisa .................................................. 27

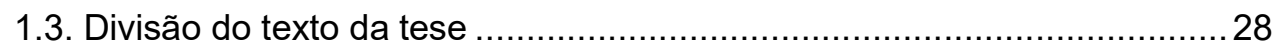

2 A população em situação de rua no Brasil .............................................29

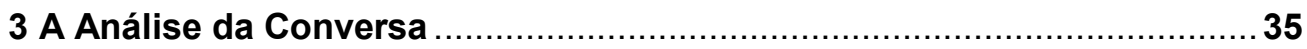

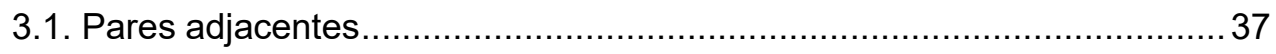

3.2. Organização de preferência ....................................................... 42

3.3. A ação da oferta ........................................................................ 44

3.4. Organização Estrutural Global das interações......................................50

4 Pressupostos metodológicos ...................................................... 55

4.1. A abordagem (auto)etnográfica .................................................... 56

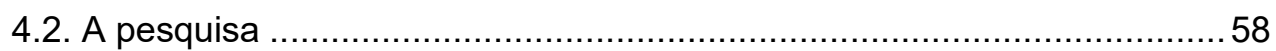

4.2.1. O universo da pesquisa ......................................................58

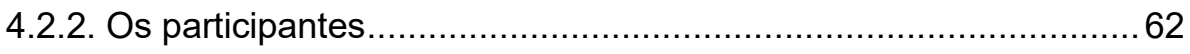

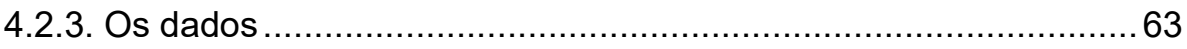

5 Notas de campo sobre o trabalho da equipe de abordagem social: o complexo processo de intervenção social ...........................................67

5.1. As fases do trabalho da intervenção social.......................................67

5.2. Os diferentes tempos do processo de reinserção social .........................69

5.2.1. O caso de Dona Joana .......................................................... 70

5.2.2. O caso de Acácia ............................................................ 72

6 Organização estrutural global da abordagem social TSN ....................77

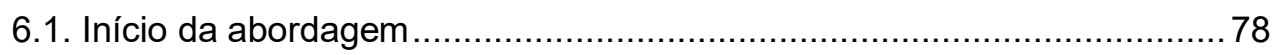

6.1.1. Convocação (Summons)-resposta ....................................... 79

6.1.2. Saudação-saudação/apresentação-apresentação....................... 81

6.1.3. Oferta de alimento ou produtos - aceite/recusa.......................... 86

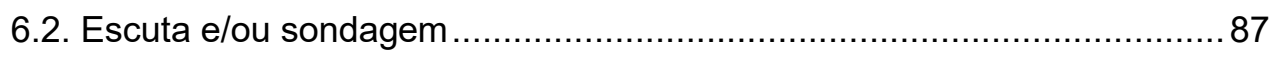

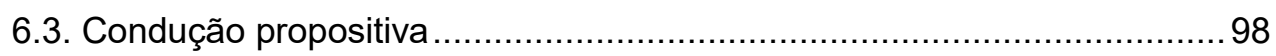

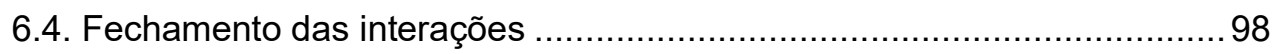

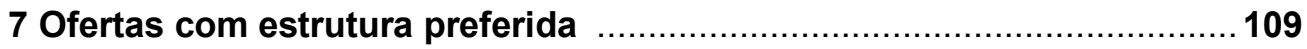

7.1. Ofertas de participação em curso de chocolates .................................. 109

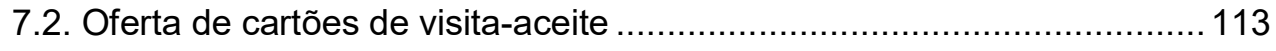

8 Ofertas com estrutura despreferida: atendimento psicológico .............. 117

8.1. Anúncio da oferta de atendimento psicológico-aceite ........................... 119

8.2. O par Oferta-Aceite ........................................................................ 121 
8.3. O par Oferta-Resistência ............................................................... 130

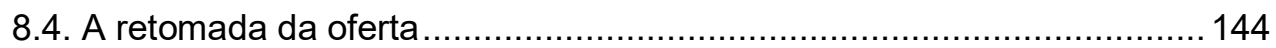

8.4.1. Retomada de ofertas anunciadas: aceite e recusa ................... 145

8.4.2. Retomada de Oferta em que a SPP foi adiada ......................... 150

8.4.2.1. Retomada de oferta-Aceite .................................... 150

8.4.2.2. A retomada de ofertas e novo adiamento da SPP ....... 152

9 Ofertas com estrutura despreferida: atendimento psicológico .............. 158

9.1. Contribuições teóricas da tese ........................................................ 159

9.2. Contribuições aplicadas da tese ...................................................... 160

10 Referências bibliográficas ............................................................ 163

Anexos 


\section{Lista de abreviaturas e siglas}

AC Análise da Conversa

BPC Benefício da Prestação Continuada

CAPS Centro de Atenção Psicossocial

CEP Comitê de Ética e Pesquisa

CLISSIS Centro Lusíada de Investigação em Serviço Social e Intervenção Social

CRAS Centros de Referência de Assistência Social

CREAS Centros de Referência Especializados de Assistência Social

CREPOP Centro de Referência Especializado para População de Rua

CrêSer Programa Acreditando no Ser humano

CVP Comunidade Vida e Paz

DIPP Grupo Discurso, Interação e Práticas Profissionais

DPU Defensoria Pública da União

ENEM Exame Nacional do Ensino Médio

IBGE Instituto Brasileiro de Geografia e Estatística

LOAS Lei Orgânica da Assistência Social

LRT Local Relevante de Transição do turno

MDS Ministério de Desenvolvimento Social e Combate à Fome

MNPSR Movimento Nacional de População em Situação de Rua

OEG Organização Estrutural Global

ONGs Organizações Não Governamentais

ONU Organização das Nações Unidas

PDSE Programa de Doutorado Sanduíche no Exterior

PPP Primeira Parte do Par

PR Pergunta-Resposta

REDLAD Rede Latino-americana de Análise do Discurso da Pobreza

SMASDH Secretaria Municipal de Assistência Social do Rio de Janeiro

SPP Segunda Parte do Par

SUAS Sistema Único de Assistência Social 
TCLE Termo de Consentimento Livre e Esclarecido

TSN Turma da Sopa de Niterói

UCT Unidade de Construção do Turno 


\section{Lista de quadros}

Quadro 1 - Síntese da Tipificação Nacional de Serviços

Socioassistenciais

Quadro 2 - Esquema das situações de permanência na rua

32

Quadro 3 - Possibilidades de expansão do par adjacente

Quadro 4 - Síntese de Questões Interacionais Importantes na análise da oferta de atendimento 
"A rua, concreta, discreta Nos mostra a frieza da sociedade E a tristeza de um povo esquecido. A rua, cinza, prateada, concreta, discreta, Esconde o brilho da lua Através da escuridão solitária Nos mostra o pouco caso dos governantes

E a tristeza de um povo esquecido. A rua, vazia, fria, Cinza, prateada, Concreta, discreta,

Sufoca os sentimentos,

Entristece a felicidade do sorriso,

Apaga o brilho do olhar, Nos mostra as drogas da vida $E$ a tristeza de um povo esquecido. A rua, violenta, imponente, vazia, fria, Cinza, prateada, concreta, discreta, Acaba com a alma infantil, A brincadeira com a bola

E a roupa colorida Que caracterizam as crianças. Assim, mais uma vez, a rua nos mostra A frieza da sociedade, O pouco caso dos governantes,

As drogas da vida

E a tristeza de um povo esquecido". (Mariana Zayat Chammas, grifos nossos) 


\section{Introdução 1}

Viver no meio da rua não é um problema novo. Se não é tão antigo quanto a própria existência das ruas, da vida urbana, remonta, pelo menos, ao renascimento das cidades, no início do capitalismo. A existência de hordas de miseráveis nas cidades pré-industriais - e pelo menos após a revolução industrial - chamou atenção de pensadores e de romancistas. Influenciou Charles Dickens e Victor Hugo, na literatura, e Marx e Engels, no pensamento político (Bursztyn, 2003, p. 19).

Como aponta Bursztyn (2003), as desigualdades sociais estão presentes no mundo inteiro, e uma de suas consequências, bastante antiga, é o drama vivenciado por pessoas que moram nas ruas, principalmente nas grandes metrópoles. As causas que levam alguém a viver na rua podem ser muitas. Dentre essas, cito aquelas que levaram pessoas com quem tive contato a ir para a rua. São elas: desemprego; problemas financeiros, psicológicos, familiares ou com tráfico de drogas/milícias; violência doméstica; vícios; desastres naturais que provocaram a perda da casa, localizada em área de risco; perda de entes queridos e, no caso de migração interna - especialmente de nordestinos ou de pessoas oriundas de cidades interioranas do Brasil -, o insucesso na busca de trabalho, de meios para uma vida melhor.

A população que toma as ruas como moradas, temporariamente ou não, é expressiva. Há, inclusive, os que já nascem na rua, onde - sem perspectiva nem vontade de sair - acabam por morrer, sem nem mesmo entrarem para as estatísticas ou serem notados. A morte é um dos meios de saída da rua. Na maioria das vezes, o Estado não cumpre o seu papel no que diz respeito a políticas públicas que garantam os direitos sociais, enquanto cidadãos/ãs, previstos na Constituição Federal de 1988:

Art. $6^{\circ}$ São direitos sociais a educação, a saúde, a alimentação, o trabalho, a moradia, o transporte, o lazer, a segurança, a previdência social, a proteção à maternidade e à infância, a assistência aos desamparados, na forma desta Constituição. (Redação dada pela Emenda Constitucional $\mathrm{n}^{\mathrm{o}}$ 90, de 2015).

\footnotetext{
${ }^{1}$ Uma vez que este capítulo possui relatos dos caminhos da pesquisa e de experiências pessoais, algumas de suas subseções foram escritas em primeira pessoa do singular, diferentemente do que ocorre nos demais capítulos.
} 
Há, contudo, Organizações Não Governamentais (ONGs) ${ }^{2}$ voltadas para prestar assistência a essa população, que, em geral, se torna "invisível". O impacto desse trabalho assistencial ainda é muito pequeno, considerando-se a drástica realidade brasileira, mas, por meio do trabalho dessas Organizações, se torna possível dar visibilidade a essas pessoas, escutando-as, acolhendo-as, atendendo algumas de suas necessidades básicas e, em alguns casos, abrindo possibilidades de saída das ruas.

É preciso, porém, esclarecer os limites com que estamos empregando, aqui, a expressão 'reinserção social'. Em primeiro lugar, é equivocado pensar em reinserção, uma vez que os moradores em situação de rua são parte da população do país. No entanto, como segundo ponto, esse pertencimento deve ser colocado em suspeição, se considerarmos que os moradores em situação de rua ainda não constam no censo demográfico realizado pelo Instituto Brasileiro de Geografia e Estatística (IBGE). Soma-se a isso o fato de que, de um modo geral, essa população é tratada como invisível pela sociedade. Isto quando não é tratada como "lixo" humano, o que é ratificado por políticas públicas de higienização que buscam, esconder essa população, arrancando-as, especialmente, dos lugares frequentados por turistas.

Considerando-se o trabalho realizado pela ONG aqui em estudo, a Turma da Sopa de Niterói, (TSN), que atua junto à população em situação de rua ou vulnerabilidade social, também é equivocado pensar que o trabalho realizado é, estritamente falando, de reinserção social. A expressão, no presente trabalho, é usada no sentido de intervenção social para o atendimento a algumas necessidades básicas relacionadas aos muitos direitos que são garantidos, na Constituição Federal de 1988, a esses cidadãos/ãs, mas que, na prática, lhes são negados. Nas palavras da assistente social Maralice dos Santos $^{3}$, que morou três anos na rua e hoje é coordenadora estadual do Movimento Nacional de População em Situação de Rua (MNPSR), no Rio de Janeiro: "Somos pessoas que temos apenas o direito de não

\footnotetext{
${ }^{2}$ Além das ONGs, há também entidades governamentais que têm a função de prestar auxílio a essas pessoas, porém, elas não dão conta do contingente de rua e, muitas vezes, funcionam precariamente. ${ }^{3}$ Disponível em: http://agenciabrasil.ebc.com.br/geral/noticia/2017-06/numero-de-pessoas-emsituacao-de-rua-aumenta-mais-de-150-em-3-anos-no-rio . Data de acesso:03 /04/2018
} 
ter direitos. Somos o lixo da sociedade, que nossos governantes querem colocar debaixo do tapete".

Apesar da drástica realidade da situação de rua, é possível ratificar que houve marcos históricos no que diz respeito à organização da política de Assistência Social no Brasil, a nível nacional bem como municipal, com a implantação dos Centros de Referência de Assistência Social (CRAS) e dos Centros de Referência Especializado de Assistência Social (CREAS), desde a criação do Sistema Único de Assistência Social (SUAS) - instituído como lei, em 2011, cuja função é a da Assistência Social no campo da proteção social brasileira, direito de todos/as os/as cidadãos/ãs brasileiros/as desde a Constituição Federal de 1988. Foi nesse cenário que houve a aprovação pelo Conselho Nacional de Assistência Social (CNAS), mediante a Resolução $n^{\circ}$ 109, de 11 de novembro de 2009, da Tipificação Nacional dos Serviços Socioassistenciais. Por meio dessa normativa, foi possível a padronização dos serviços de proteção social básica e especial, no Brasil, com o estabelecimento de seus conteúdos essenciais, público a ser atendido, seus propósitos, bem como os resultados almejados para a garantia dos direitos socioassistenciais. Essa padronização já inclui a população em situação de rua como um dos seus públicos e pode ser resumida no quadro a seguir:

Quadro 1- Síntese da Tipificação Nacional de Serviços Socioassistenciais

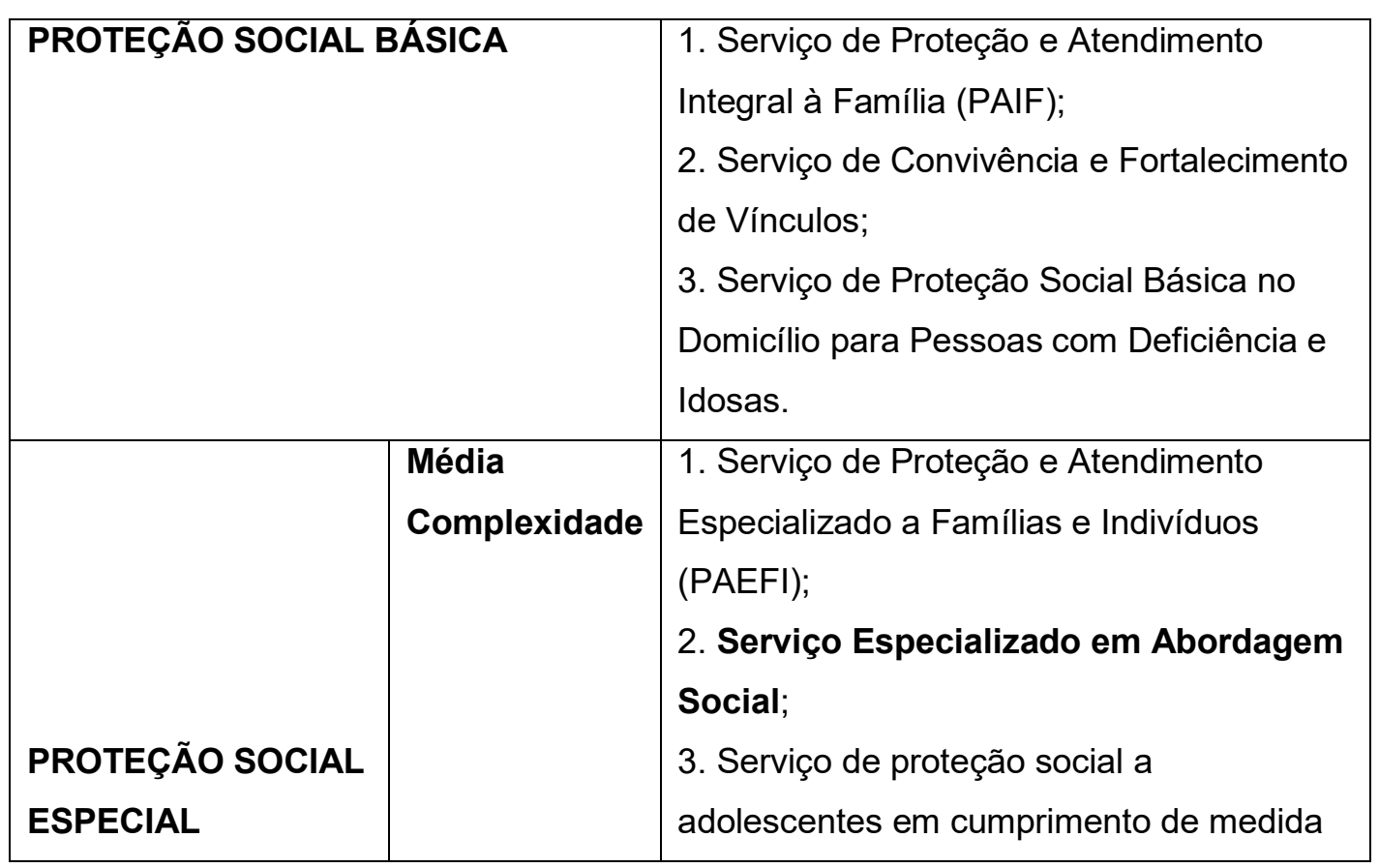




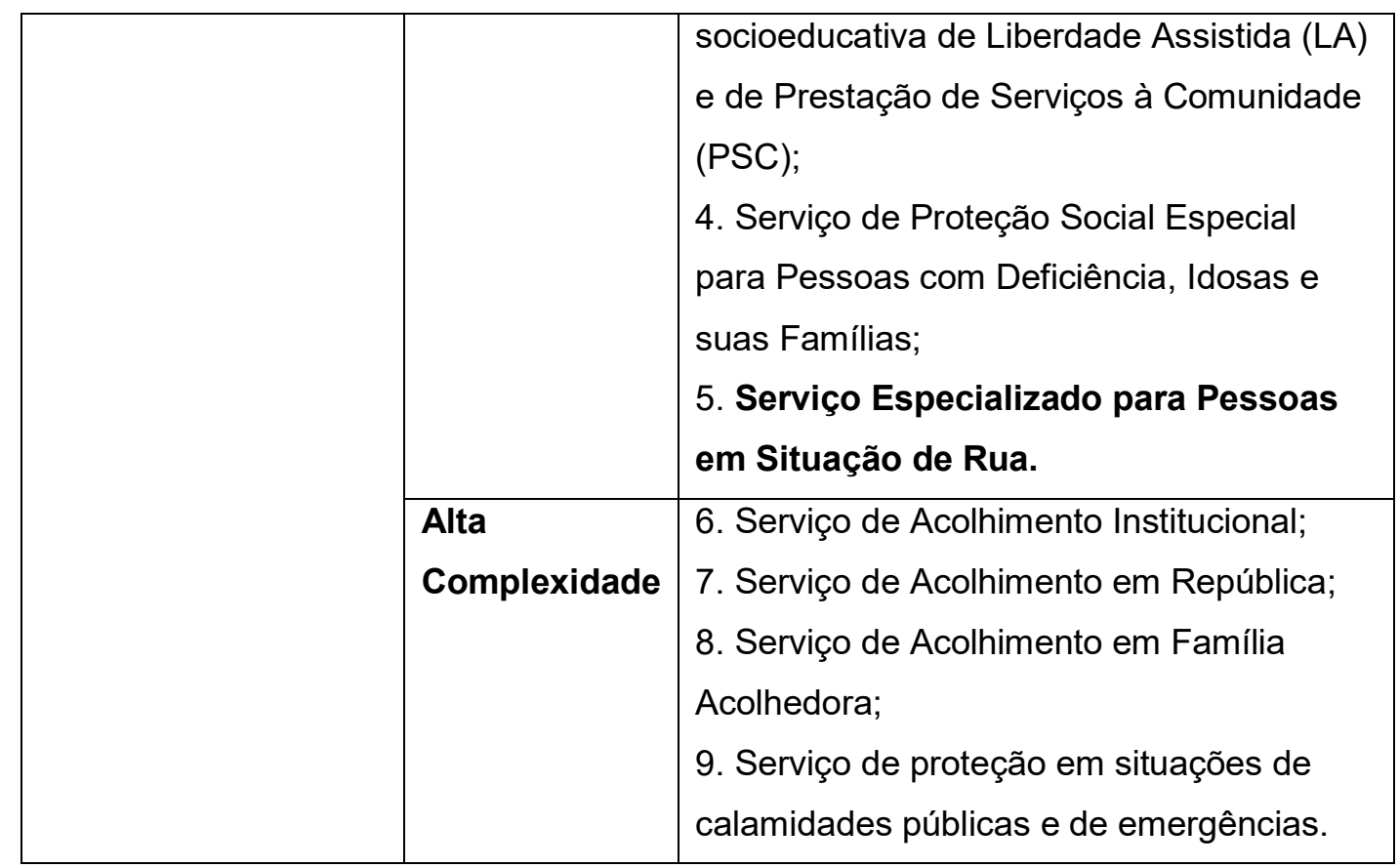

Fonte: Brasil, 2014, p. 10, grifos nossos.

Assim, a Assistência social às pessoas em situação de rua se enquadra dentro da proteção social especial, de média complexidade.

O trabalho de uma ONG, por sua vez, não, necessariamente, envolve profissionais com formação em Serviço Social. O trabalho é realizado por pessoas da sociedade civil que desejam contribuir para a melhoria das condições de vida da população de rua e, se possível, encontrar meios para satisfazer desejos como os de sair da rua, voltar para a família, ser reinserido/a no mercado de trabalho, ou simplesmente atender a necessidades imediatas como encaminhamento à assistência médica, atendimento psicológico. A expressão reinserção social é vista, portanto, como um ideal do qual a intervenção social é a parte real, aquela que busca reduzir os danos - desde a autoestima à garantia de alguns dos direitos sociais daquela população. A entrada do terceiro setor vem somar na luta para reduzir a desigualdade social da sociedade brasileira, sem desresponsabilizar o Estado de cumprir suas obrigações no que diz respeito à proteção social.

Essas práticas consistem em atividades de reintegração, no sentido de ser um trabalho que busca: 1) dar visibilidade às pessoas em situação de rua e 2) encontrar maneiras de que elas sejam vistas não só pelos/as integrantes da $\mathrm{ONG}$, mas pela sociedade, como um todo, e de que seja promovida a autonomia delas, por meio de 
orientações sobre acesso aos seus direitos, contribuição para aquisição de trabalhos formais ou informais, retorno à casa ou à família, encaminhamento para abrigo ou assistência psicológica, oftalmológica, odontológica, etc.

Considerando-se esse cenário, a proposta desta pesquisa é a de investigar o modo como voluntários/as da equipe de abordagem social da ONG Turma da Sopa de Niterói (TSN) realizam atividade de assistência a moradores/as em situação de rua. É interessante destacar que a Secretaria Municipal de Desenvolvimento Social (SMDS) do Rio de Janeiro publicou a resolução n ${ }^{\circ} 64$ de 12 de abril de 2016, que cria e regulamenta o protocolo do serviço especializado em abordagem social a ser desenvolvido pela SMDS, mas não nos referimos aqui a essa abordagem social especializada, pois, embora possamos encontrar algumas similaridades, não se trata do serviço de proteção social especializado. Além disso, essa nomenclatura trata-se de uma categorização dada pela ONG estudada, sem necessariamente conhecer, antecipadamente, de forma aprofundada, o serviço e as normativas da SMDS.

É importante destacar que há estudos aplicados de Análise da Conversa (AC) que tratam de interações em contexto profissional do serviço social, dentre eles, podemos citar Monteiro (2011; 2016); Binet (2013); De Montigny (2018) e o conjunto de estudos de iniciativa do Observatório do Samu social de Paris, que incidem sobre a intervenção emergencial junto à população em situação de rua (Gardella et al., 2006), todos desenvolvidos fora do Brasil. A quantidade desses trabalhos na interface Análise da Conversa e saúde ${ }^{4}$ também é expressiva (Gafaranga e Britten, 2005; Heritage e Robinson, 2011; Stivers, 2002; Ostermann e Silva, 2009; Ostermann e Souza, 2009), bem como no ambiente escolar (Seedhouse, 1996; Seedhouse, 2004; Garcez, P. M. et al., 2012); ou no meio coorporativo (Vinkhuyzen; Szymanski, 2005; Walker, 1994), apenas para citar alguns.

No entanto, pouco se sabe sobre estudos de fala em interação envolvendo atividades profissionais realizadas por voluntários em contexto de/no campo de assistência social. Dado o alcance da abordagem da AC para o entendimento do que ocorre na interação, acreditamos que este estudo poderá vir a contribuir não só para

\footnotetext{
${ }^{4}$ Para uma revisão da literatura da dimensão aplicada da Análise da Conversa, seu potencial e sua viabilidade, no contexto institucional de prestação de serviços de atendimento em saúde, tanto em âmbito internacional quanto nacional, ver Ostermann; Andrade e Silva, 2013.
} 
descrever e aperfeiçoar a prática de oferecimento de ajuda/serviços realizada por voluntários/as junto aos/às assistidos/as em situação de rua, como também para fornecer insumos para a formação de voluntários envolvidos em práticas de assistência social.

Diante do grande número de pessoas em situação de rua e da urgência de programas de reinserção social dessa população, alinho-me a Schneider e Remillard (2013) na defesa de que um exame atento da conversa sobre a condição de uma pessoa sem moradia permanente é tão importante quanto estudos de aspectos práticos dessa condição, uma vez que aí encontramos informações valiosas sobre como os problemas de desigualdade social e da exclusão social são manifestados, vividos e amplificados em atos cotidianos e interações.

Nesse sentido, defendemos que o estudo da interação poderá nos ajudar a compreender um pouco melhor o universo da rua e a preencher lacunas também urgentes, como a escassez de estudos sobre o terceiro setor, sobre o trabalho voluntário e sobre a assistência social voltada para a reinserção social de pessoas em situação de rua.

Em termos aplicados, as discussões de dados produzidas a partir das trocas acadêmicas aqui elencadas contribuem de forma relevante para o desenvolvimento de um programa de capacitação interacional de voluntários/as da Equipe de Abordagem Social e também para a formação de voluntários em assistência social de outras entidades. Acreditamos que a análise proposta traz à luz problemas na interação assistente-assistido/a e, consequentemente, torna possível embasar orientações que terão impacto na tarefa de reinserção social de assistidos/as.

Nas próximas subseções, é detalhada a questão de pesquisa, assim como os objetivos e a relevância da tese.

\section{1.}

\section{A construção da questão de pesquisa}

\footnotetext{
Alguns anos atrás, ao citar a família de pobres que vivia debaixo de papelão em frente ao prédio da Faculdade onde falava, fui surpreendido pelo espanto de alunos e professores que não tinham percebido a existência daqueles pobres. Era como se eles fossem tão excluídos do mundo dos universitários que tivessem ficado invisíveis. De tão acostumados à paisagem, estes deixaram de vê-la. [...] Com o olho dos salões acadêmicos não é fácil ver quem vive no meio da rua. Só um treinamento diferente permite esta nova visão. Esse treinamento exige aliar sentimento às análises teóricas, coisa que a universidade se nega a fazer (Buarque, 2003, p. 7).
} 
Este estudo tenta fazer isto: aliar sentimento às análises teóricas. Nesta primeira parte, será descrita a construção desse elo, da trajetória desta pesquisa.

Saber que pessoas vivem em situação de rua sempre me causou uma grande tristeza e uma sensação de impotência enorme, embora o máximo que eu conseguisse fazer fosse dar alguma comida, roupa ou cobertor a alguma dessas pessoas e conversar um pouco, quando tinha oportunidade. Mas, muitas vezes, nem isso conseguia fazer, pois embora "os visse", não sabia como abordar ou oferecer algo, além de ter o receio de abordar alguém do sexo oposto, o que causava uma insegurança ainda maior, por causa da sociedade machista, da qual fazemos parte.

Em julho de 2013, porém, comecei a ver informações sobre a TSN no Facebook; ao acompanhar o grupo virtualmente, passei a ter a certeza de que gostaria de fazer parte dele. Mesmo estando consciente de que o trabalho desenvolvido pelo grupo é um "trabalho de formiguinha", dada a realidade brasileira, considerei as ações muito importantes e vi ali uma oportunidade de fazer algo. Em setembro daquele mesmo ano, tive a oportunidade de fazer o curso de voluntários e ingressar no grupo. Comecei participando do grupo de preparação da sopa, à tarde; depois, quando me senti preparada, comecei a ir também para a entrega nas ruas. Posteriormente, por questões de tempo, passei a ir apenas para as ruas. Comecei fazendo parte da equipe de entrega dos alimentos - assim como todos os que ingressam na ONG - e, algum tempo depois, fui convidada para fazer parte da equipe do Social, responsável pelo trabalho de interagir com as pessoas, buscando conhecê-las, e identificar meios e modos de reinserção social. Com o passar do tempo, fui me identificando e gostando muito do que fazia; fiquei cada vez mais envolvida e conhecendo mais o universo da população em situação de rua. Muitos/as voluntários/as entraram e saíram do grupo, que passou por modificações nas equipes. Em 2016, ajudei a montar a Equipe de Abordagem Social e passei a estar cada vez mais envolvida com todo o trabalho desenvolvido pela ONG.

Até aquele momento, o meu envolvimento com a TSN se dava apenas no âmbito pessoal. Mas, ao cursar a disciplina "Análise da Narrativa”, no Doutorado, na PUC, resolvi fazer um trabalho sobre esse universo e minha orientadora, a professora Doutora Maria do Carmo Leite de Oliveira, sugeriu entrevistar alguém que esteve ou estivesse em situação de rua. Então, entrevistei uma assistida, que 
não estava mais em situação de rua e com a qual eu havia criado um vínculo. Foi uma experiência muito rica, acadêmica e pessoalmente. Meus/minhas colegas de curso começaram a sugerir a possibilidade de eu fazer a tese naquele universo tão interessante, com o qual eu tinha tanta familiaridade. Aproximadamente na mesma época, eu descobria os estudos de Análise da Conversa aplicada e suas contribuições aos contextos institucionais, tendo acesso aos trabalhos do Grupo "A Fala-em-interação em Contextos Institucionais e Não-Institucionais", da UNISINOS, coordenado pela professora Doutora Ana Cristina Ostermann. A partir de então, comecei a vislumbrar quanto poderia trazer de contribuições para o trabalho de assistência social prestado pela $\mathrm{ONG}$, ao estudar as interações entre voluntários/as e assistidos/as. Motivou-me também o caráter inovador da pesquisa, visto que há uma vasta literatura estrangeira sobre interação em práticas de assistência social, mas não há trabalhos que abordem como isso é feito por voluntários, especialmente como é aqui o caso, no qual os que fazem parte da equipe do social possuem profissões variadas, sem necessariamente a formação em Serviço social. Soma-se a isso o fato de que estamos aqui contemplando o atendimento a pessoas em situação de rua, grupo muito específico, a partir de uma análise da falaem-interação.

Ainda em 2016, consultei à diretoria - sobre a abertura de campo na TSN que ficou animada com a possibilidade de pesquisa. Fiz, então, a proposta de mudança do projeto de pesquisa à minha orientadora; como ela sempre demonstrou bastante preocupação com o retorno social das pesquisas, aprovou a ideia e deu todo o apoio e os estímulos necessários. Assim, surgiu a ideia desta pesquisa, que foi amadurecida e incentivada, pela professora Dra. Liana Biar, na disciplina "Metodologia de Pesquisa", quando ganhou mais forma e teve sua primeira versão de pré-projeto concretizada, a qual foi sendo modificada, até que chegássemos a esta tese.

Com o objetivo de entender melhor o universo do Serviço Social, cursei, durante o primeiro semestre de 2016, a disciplina: "Proteção social e sujeitos sociais", na Universidade Federal Fluminense, no Programa de Pós Graduação de Política Social, do Departamento de Serviço Social. No final daquele ano - com o estímulo incansável de minha orientadora -, concorri ao edital do Programa de Doutorado Sanduíche no Exterior (PDSE), após encontrar o meu coorientador, 
professor Dr. Michel Binet, do Centro Lusíada de Investigação em Serviço Social e Intervenção Social (CLISSIS), que também viria a contribuir nas reflexões e análises dos dados do corpus desta tese. Ao conseguir participar do PDSE estive em Lisboa, de agosto de 2016 a fevereiro de 2017, aperfeiçoando minha formação, transcrevendo, analisando dados e conhecendo mais o universo do Serviço Social em Portugal.

Devido aos meus interesses pessoais e acadêmicos, vivenciei aprendizados e descobertas, durante o PDSE, que extrapolaram o mundo acadêmico. Em Portugal, conheci e me surpreendi com uma parcela da população vítima da miséria e da desigualdade social bem semelhante à existente no Brasil: muitas pessoas vivendo em situação de rua e/ou de grande vulnerabilidade social. Também conheci várias organizações sociais que estão preocupadas com essas pessoas e que querem, na medida do possível, fazer a diferença e amenizar seus sofrimentos sociais ${ }^{5}$ (Carreteiro, 2003). Os grupos que lá conheci, por meio de minha participação como voluntária, foram a Comunidade Vida e Paz (CVP) e o "Serve the City".

A CVP assemelha-se à TSN, mas com uma estrutura muito maior, mais amadurecida e mais completa, pois teve seu início de abordagens sociais em 1988 e continua a crescer. Ligada à igreja católica, a Comunidade Vida e Paz tem, a meu ver, um papel muito importante na reinserção social das pessoas em situação de rua (ou em condição de sem abrigo, termo do português de Portugal usado para designar tal situação), em Lisboa. Tive oportunidade de ser voluntária na referida ONG, de outubro de 2017 a fevereiro de 2018. Durante esse período, pude acompanhar diversas equipes, inclusive a Equipe Técnica - que seria correspondente à Equipe de Abordagem Social da TSN - formada por uma psicóloga contratada e por voluntários/as mais antigos/as. Com essas equipes, pude aprender muito sobre a população em situação de rua, de Portugal, bem como sobre a prática de abordagem social realizada por pessoas que também não têm formação acadêmica em Serviço Social. Além disso, cheguei a gerar dados - referentes a algumas das abordagens feitas pela CVP - que serão analisados e divulgados, em trabalhos posteriores, no formato de artigos.

\footnotetext{
5“'O sofrimento social é tema que vem sendo discutido por pesquisadores brasileiros em diferentes contextos, normalmente associando esta condição às populações socialmente excluídas vítimas de violência, seja esta originada no Estado ou mesmo na família, com atenção especial para sua repercussão nos lugares sociais e nos corpos desses grupos." (Carvalho, 2008, p. 10).
} 
A Organização Serve the City também me chamou atenção, não somente pelo cuidado e respeito às pessoas atendidas, mas, principalmente, por um tratamento mais igualitário dos/as assistidos/as, o que favorece um convívio mais simétrico, por meio do jantar mensal, que reúne voluntários/as e assistidos/as convidados/as. Nesse jantar, as pessoas recebem um adesivo com seu nome e ceiam juntos, sentadas à mesa, onde podem conversar livremente, conhecer-se e dar atenção umas às outras. Minha participação em um desses jantares foi muito gratificante. Duas das pessoas que se sentaram à mesma mesa que eu falaram muito sobre a vida, o mundo e suas revoltas, que eram as mesmas que as minhas. Percebi que o que nos distinguia era o fato de que elas estavam enfrentando, em suas próprias realidades, aqueles desafios sobre os quais estávamos conversando e, por isso, falavam com mais propriedade sobre o assunto. Um deles, que vivia em situação de rua há anos, brincou que "a aula iria acabar" quando nos despedíssemos, afinal ele estava dando uma aula sobre a vida e sobre Portugal. De fato, estava mesmo. Também rimos, falamos das belezas de Portugal e do Brasil, bem como das mazelas e desigualdades sociais em ambos os países. Fomos tratados de forma igual, como deveria ser em todos os lugares: recebemos tratamento respeitoso, digno e humanizado. Tal situação me trouxe à lembrança a fala de uma assistida em Niterói-RJ. Em conversa sobre sua documentação, ela apresentou receios de ir sozinha a uma repartição pública para retirada dos documentos, por isso, eu disse que poderia acompanhá-la, caso ela quisesse, para ajudar que ela fosse tratada como merece, neste processo. Ela, por sua vez, respondeu que nem lembrava o que é e como é ser tratada da forma que merece.

Com meu retorno ao Brasil, em março de 2018, retomei as minhas atividades na TSN e continuei o desenvolvimento desta pesquisa, sem preocupações em gerar muitos dados a mais. Porém, permaneci em constante reflexão a respeito da nossa prática e continuei alimentando minhas notas de campo sobre o objeto de estudo deste trabalho: a investigação da prática de assistência social realizada por voluntários da equipe de abordagem social, da TSN, aos/às moradores/as em situação de rua.

Após discorrer sobre o meu percurso na construção da questão de pesquisa, chego aos seguintes questionamentos desta tese: Como se dá a prática da equipe de abordagem social? Como pessoas que não têm formação em Serviço Social 
realizam o trabalho de abordagem social? Que tipo de oferta costuma ser aceita ou recusada e de que forma isso ocorre? Estas são as perguntas que tentaremos responder, ao longo das discussões apresentadas nos capítulos de análise de dados.

Por fim, considero válido reconhecer que, apesar de os profissionais da área de Serviço Social não terem uma formação nos estudos da interação, eles são preparados para praticar a assistência social e lidar com assistidos/as ou usuários/as, termo utilizado no Serviço Social brasileiro para se referir àqueles/as que chamamos de assistidos/as. Já os/as voluntários/as contam apenas com sua intuição, boa vontade e orientações gerais oferecidas pelas ONGs, para realizarem seu trabalho. Logo, é de se supor que possam ter problemas de diferentes ordens na sua interação com o/a assistido/a, o que justifica o gesto de descrever as microações sociais (Sacks, 1992; Sacks; Schegloff; Jefferson, 1974), como propomos na presente pesquisa.

\section{2 .}

\section{Objetivos e relevância da pesquisa}

O objetivo geral desta tese é contribuir para o entendimento da prática da assistência social realizada por voluntários/as e orientada para o processo de reinserção social de moradores/as em situação de rua.

\section{Objetivos específicos:}

i) Descrever as etapas do processo de intervenção social realizado pela equipe de abordagem junto a moradores/as em situação de rua ou de vulnerabilidade social;

ii) Apresentar a Organização Estrutural Global das abordagens sociais TSN;

iii) Descrever as microações interacionais realizadas em cada etapa da abordagem;

iv) Descrever quais recursos interacionais os/as voluntários/as mobilizam para fazer ofertas de ajuda/serviços; 
v) Examinar as respostas aos oferecimentos produzidos pelos/as assistidos/as, de modo a identificar que práticas se mostram bemsucedidas ou não.

\section{3}

\section{Divisão do texto da tese}

Esta tese foi dividida em nove capítulos. Os quatro primeiros são norteadores do estudo: $1^{\circ}$ ) introdução, $2^{\circ}$ ) breve revisão sobre a população em situação de rua no Brasil; $3^{\circ}$ ) exposição da perspectiva teórica da Análise da Conversa e $4^{\circ}$ ) descrição da metodologia de pesquisa utilizada. Na sequência, temos quatro capítulos de análise de dados: $5^{\circ}$ ) notas de campo sobre o complexo processo de abordagem social; $6^{\circ}$ ) Organização da Estrutura Geral da abordagem social, com identificação de (micro)ações realizadas em cada etapa do processo; $7^{\circ}$ ) descrição das ofertas com estrutura preferida; $8^{\circ}$ ) discussão das ofertas com estrutura despreferida; e, por fim, no $9^{\circ}$ ), fazemos as considerações finais, apresentando as principais contribuições teóricas e aplicadas deste estudo. 


\title{
A população em situação de rua no Brasil
}

\begin{abstract}
Cores, ruídos e pessoas: a cidade se movimenta, alternando também seus protagonistas e figurantes. Quanto maior a cidade, mais movimentada é, sobretudo quando nos aproximamos dos centros comerciais. As pessoas, de forma acelerada, correm para dar conta de demandas e compromissos. Nesse vaivém, pouco se conhece e se observa. Em geral, a cidade não deixa transparecer tudo o que existe; muito menos se observam as contradições expostas.

Um papelão, uma trempe, um chinelo, uma mochila... Possivelmente, esse é um dos muitos locais por onde pessoas que não têm casa para morar, chamadas hoje população em situação de rua, passaram, vivem ou viveram; melhor dito, sobrevivem ou sobreviveram. (Bove; Figueiredo, 2015, grifos nossos).
\end{abstract}

No Brasil, o número de pessoas que (sobre)vive nas ruas é imenso, mas faltam dados oficiais precisos e atualizados sobre esse grupo, pois essa parte da população é excluída dos censos do Instituto Brasileiro de Geografia e Estatística - IBGE, fato que contraria a missão institucional desse órgão: "Retratar o Brasil com informações necessárias ao conhecimento de sua realidade e ao exercício da cidadania ${ }^{6 "}$. Logo, tal situação invisibiliza as pessoas em situação de rua e dificulta a criação de políticas públicas voltadas para elas.

A única pesquisa nacional ampla ${ }^{7}$ sobre essa população foi realizada pelo Ministério de Desenvolvimento Social e Combate à Fome (MDS $)^{8}$, concretizando a I Pesquisa Nacional sobre a População em Situação de Rua, realizada em 2008 e publicada em 2009. Este estudo apresenta dados e discussões importantes sobre diferentes questões: a trajetória da construção desse censo, com seus desafios metodológicos; a saúde das pessoas em situação de rua; suas dinâmicas sociais, estratégias de adaptação e sobrevivência diante da escassez em que vivem no meio urbano; questões de gênero; caminhos de reconhecimento de seus direitos e a atuação do MDS no atendimento a essa população, entre outras. Há de se considerar, também, os levantamentos realizados pelas Secretarias de Assistência Social de alguns municípios, embora haja divergências de conceitos e

\footnotetext{
${ }^{6}$ Disponível em: https://www.ibge.gov.br/institucional/o-ibge.html Data de acesso: 20/05/2019.

${ }^{7}$ Apesar de ter sido a mais ampla, ela não atingiu todo o território brasileiro. Levou em consideração um público composto por pessoas com 18 anos completos ou mais e compreendeu 71 cidades, sendo 48 municípios com mais de 300 mil habitantes e 23 capitais. Ficaram fora cidades que já estavam desenvolvendo pesquisas semelhantes, dentre elas: São Paulo, Belo Horizonte e Recife. O levantamento do MDS registrou 31,9 mil adultos em situação de rua. Somando-se os resultados de pesquisas feitas à parte nas cidades citadas, esse contingente foi ampliado para 44 mil pessoas. ${ }^{8}$ Atualmente, transformado em secretaria vinculada ao Ministério da Cidadania.
} 
metodologias, para realizar contagens, amostras ou mesmo pesquisas qualitativas, o que dificulta o conhecimento de um panorama geral no país.

Natalino (2016) discute a pesquisa realizada pelo Instituto de Pesquisa Econômica Aplicada - IPEA, do Brasil, e ratifica o quanto a falta de dados oficiais sobre a população em situação de rua prejudica a implementação de políticas públicas voltadas para essa população e contribui para a manutenção de sua invisibilidade. Dados desse estudo estimaram ${ }^{9}$ que haveria, em 2015, um total de 101.854 pessoas em situação de rua no Brasil. Essa população se concentra, majoritariamente, nas grandes capitais, como o Rio de Janeiro. Embora não tenhamos dados do IBGE ou estimativas mais recentes, acreditamos que essa população tem aumentado consideravelmente. Dados locais ratificam isso: de acordo com a planilha de atendimento da Secretaria Municipal de Assistência Social do Rio de Janeiro (SMASDH) ${ }^{10}$, havia, no ano de 2017, 15 mil pessoas vivendo somente nas ruas da cidade do Rio de Janeiro; esse é um número três vezes maior do que o registrado em 2013. Isso sem contar com as cidades vizinhas, que também apresentam um número cada vez maior de pessoas em situação de rua, como é o caso da cidade de Niterói-RJ.

Segundo o jornal "O Globo"11, conforme balanço encaminhado pela prefeitura de Niterói à Comissão de Direitos Humanos da Câmara, o total de abordagens realizadas pela Secretaria Municipal de Assistência Social e Direitos Humanos de Niterói, cidade em que foi realizada esta pesquisa, mais do que duplicou em 2017, em relação a 2016, e já crescia nesse ritmo, nos primeiros meses de 2018.

\footnotetext{
9 Trata-se de uma "estimativa da população em situação de rua no Brasil utilizando-se de dados disponibilizados por 1.924 municípios via Censo do Sistema Único de Assistência Social (Censo SUAS). Com base nessas informações, realizou-se um modelo linear generalizado, com a variável de resposta assumindo uma distribuição de Poisson, considerando o tamanho da população municipal como variável de exposição ao fenômeno, ou offset, para estimar a população em situação de rua para as demais municipalidades brasileiras. O modelo teórico considera variáveis de crescimento demográfico, centralidade e dinamismo urbano, vulnerabilidade social e serviços voltados à população de rua, bem como o número de pessoas em situação de rua cadastradas no Cadastro Único para Programas Sociais do governo federal (Cadastro Único)" (Natalino, 2016, p. 5).

${ }^{10}$ Disponível em: http://www.rio.rj.gov.br/web/guest/exibeconteudo?id=6982189. Data de acesso: 03/04/2018

${ }^{11}$ Isso não é novidade, vários especialistas defendem isso para que possamos ter ações mais eficazes na redução da questão social da população em situação de rua. A respeito, ver: $<$ https://oglobo.globo.com/rio/bairros/abordagens-populacao-de-rua-em-niteroi-mais-que-dobramem-um-ano-23257280> Data de acesso: 10/01/2019.
} 
Como nos mostra a reportagem supracitada, há clareza de que o problema é complexo, de que há necessidade de opções de acolhimento que não se restrinjam aos abrigos e de que a assistência social precisa ser integrada a outras políticas sociais, como saúde, educação, habitação e emprego. Mas há clareza também de que o tamanho dessa desse segmento social exige mais mãos para o trabalho de assistência social.

No dia 22 de fevereiro de 2019, ocorreu o I Seminário de Fortalecimento do Movimento Nacional da População em Situação de Rua do Rio de Janeiro ${ }^{12}$, no auditório da Defensoria Pública da União (DPU), tendo como tema "Direito à habitação e geração de renda", aberto com o debate sobre a exclusão da população em situação de rua dos censos do IBGE, por meio da fala do defensor regional de direitos humanos da DPU/RJ, Thales Arcoverde Treiger. De acordo com ele:

\begin{abstract}
é imprescindível que o Poder Público tenha especial atenção às pessoas em situação de rua. A omissão estatal estrutural fica evidente na medida em que essas pessoas sequer têm respeitado o seu direito de ser mapeadas pelo Censo da população brasileira. [...] A ausência de estatísticas confiáveis perpetua a relação histórica de negligência. O IBGE ocupa papel relevante na efetivação de políticas públicas que dizem respeito à consecução dos direitos humanos. É por meio do Censo que a União define as prioridades a serem atendidas e é inadmissível que se tenha dados referentes a cabeças de gado e a animais de estimação, mas não da população em situação de rua. [...] Sem a contagem desta parcela da população, fica impossível estabelecer qualquer amparo significativamente razoável a fim da implementação de políticas públicas realmente eficazes voltadas especificamente para este segmento, por isso, a DPU vem tentando fazer valer a decisão na ação civil pública que impõe ao IBGE a inclusão destas pessoas no Censo 2020.
\end{abstract}

Não restam dúvidas da urgência de inclusão das pessoas em situação de rua nos censos do IBGE, bem como da importância de políticas públicas amplas que possam atingir esse segmento social e amenizar a desigualdade social no país.

Uma vez que este estudo se insere em um Programa de Estudos da Linguagem, é imprescindível esclarecer a opção e ênfase da nossa escolha pela expressão "população/pessoa em situação de rua". Tal expressão traduz "as condições de 'fragilidade', 'incerteza', 'provisoriedade' e 'precariedade' nas quais vivem indivíduos e grupos sem-lugar que, regra geral, não utilizam 'moradia

\footnotetext{
12 O seminário reuniu defensores públicos federais e estaduais, pessoas em situação de rua e representantes do Estado e de movimentos da sociedade civil que atuam em defesa dos direitos deste segmento social. Enquanto membro da TSN e cidadã, eu tive a oportunidade de participar do evento e também ouvir as próprias pessoas em situação de rua a respeito do descaso do Poder Público com elas, bem como sobre a organização do Movimento Nacional da População em Situação de rua, na luta pelos seus direitos. Informações sobre $o$ evento podem ser encontradas em: $<$ http://dpurj.blogspot.com/2019/02/?m=1 > Data de acesso: 01/03/2019.
} 
convencional regular"” (Nonato; Raiol, 2016, p. 82). É importante dizer, porém, que vemos a situação de rua como uma questão social, que vai muito além de fatores subjetivos individuais.

No Decreto Presidencial 7053, de 31 de dezembro de 2009, que institui a Política Nacional para a População em Situação de Rua e seu Comitê Intersetorial de Acompanhamento e Monitoramento, no artigo $1^{\circ}$, há uma definição sobre esse grupo, a quem o decreto se destina:

[...] a população em situação de rua é um grupo populacional heterogêneo que possui em comum a pobreza extrema, os vínculos familiares interrompidos ou fragilizados e a inexistência de moradia convencional regular, e que utiliza os logradouros públicos e as áreas degradadas como espaço de moradia e de sustento, de forma temporária ou permanente, bem como as unidades de acolhimento para pernoite temporário ou como moradia provisória.

É possível dizer que a situação de rua funciona como uma espécie de areia movediça ${ }^{13}$, pois, quanto mais tempo a pessoa (sobre)vive nela, mais difícil se torna a sua saída. Ao falar sobre o processo de saída da rua, Vieira, Bezerra e Rosa (2004, p. 94) afirmam:

Este processo torna-se mais difícil à proporção que aumenta o tempo de rua. De forma geral, o indivíduo vai sofrendo um processo de depauperamento físico e mental em função da má alimentação, precárias condições de higiene e pelo seu constante uso do álcool ${ }^{14}$.

As autoras defendem que seria possível identificar três situações diferentes em relação à permanência na rua: ficar na rua (circunstancialmente); estar na rua (recentemente) e ser de rua (permanentemente), que podem ser resumidas no quadro a seguir:

Quadro 2 - Esquema das situações de permanência na rua

\begin{tabular}{|l|l|l|l|}
\cline { 2 - 4 } \multicolumn{1}{c|}{} & FICAR NA RUA & ESTAR NA RUA & SER NA RUA \\
\hline Moradia & $\begin{array}{l}\text { pensões, } \\
\text { albergues, } \\
\text { alojamentos }\end{array}$ & $\begin{array}{l}\text { rua, albergues } \\
\text { pensões } \\
\text { (alternadamente) }\end{array}$ & $\begin{array}{l}\text { rua, mocós } \\
\text { (eventualmente } \\
\text { albergues, } \\
\text { pensões) }\end{array}$ \\
\hline
\end{tabular}

${ }^{13}$ Metáfora ouvida no curso de formação de voluntários da Turma da Sopa de Niterói e constatada ao conhecer, um pouco mais de perto, as histórias e vidas de pessoas em situação de rua.

${ }^{14}$ Nota nossa: Estudos mostram que a bebida é o meio de socialização mais comum em meio à população em situação de rua e que, para o indivíduo ser aceito pelos pares e aguentar os sofrimentos sociais impostos por essa realidade, tende a beber (cf. Trubilhano, 2011; Vieira et. all., [1994] 2004). 


\begin{tabular}{|c|c|c|c|}
\hline & $\begin{array}{l}\text { (eventualmente } \\
\text { rua) }\end{array}$ & & \\
\hline Trabalho & $\begin{array}{lr}\text { construção } & \text { civil, } \\
\text { empresas } & \text { de } \\
\text { conservação } & \text { e } \\
\text { vigilância } & \end{array}$ & $\begin{array}{lr}\text { bicos } & \text { na } \\
\text { construção } & \text { civil, } \\
\text { ajudante } & \text { geral, } \\
\text { entregador/a } & \text { de } \\
\text { jornal } & \text { ou } \\
\text { panfletos, } & \\
\text { catador/a } & \text { de } \\
\text { papel } & \text { ou } \\
\text { recicláveis, } & \text { em } \\
\text { geral } & \end{array}$ & $\begin{array}{l}\text { bicos, } \\
\text { especialmente, de } \\
\text { catador de papel } \\
\text { ou recicláveis, em } \\
\text { geral, } \\
\text { guardador/a de } \\
\text { carros, } \\
\text { entregador/a de } \\
\text { jornal ou panfletos }\end{array}$ \\
\hline $\begin{array}{l}\text { Grupo de } \\
\text { referência }\end{array}$ & $\begin{array}{l}\text { companheiros/as } \\
\text { de trabalho, } \\
\text { parentes }\end{array}$ & $\begin{array}{l}\text { companheiros/as } \\
\text { de rua e de } \\
\text { trabalho }\end{array}$ & grupos de rua \\
\hline
\end{tabular}

Fonte: Reproduzido de Vieira, Bezerra e Rosa, 2004, p. 95, com adaptações.

Esse esquema é bem representativo da situação de rua e essa diferenciação aparece também no discurso ${ }^{15}$ das pessoas que (sobre)vivem ou (sobre)viveram em situação de rua.

Praticamente todos os trabalhos que estudam essa população reconhecem a extrema pobreza, a heterogeneidade e a invisibilização como características desse segmento social. Algo que também costuma ser destacado é o estigma e as diferentes formas de violência às quais essas pessoas são submetidas. Como afirmam Vieira, Bezerra e Rosa (2004, p. 18), além de se encontrar em situação de extrema pobreza, a população de rua tem seu lugar social demarcado, sendo avaliada negativamente pela classe trabalhadora e pela sociedade como um todo.

É possível encontrar estudos sobre a população de rua em diversas áreas. Destacamos algumas obras com grandes contribuições, para melhor entender esse segmento social e o problema da exclusão social. "No meio da rua: Nômades, Excluídos e viradores”, organizado por Bursztyn (2003), reúne oito textos que

${ }^{15}$ A respeito, ver De Oliveira e Lisboa, 2017. 
discutem questões tais como: estratégias de sobrevivência dessa população, os impasses das políticas públicas, suas relações com o meio urbano e desafios teóricoconceituais da explicação do drama de viver nas ruas. "População de rua: quem é, como vive, como é vista”, organizado por Vieira, Bezerra e Rosa (2004), é fruto do esforço conjunto entre a Secretaria de Bem-Estar Social de São Paulo, em 1991, e organizações não governamentais, fazendo o primeiro levantamento sobre pessoas em situação de rua em São Paulo, mas, infelizmente, com discussões contemporâneas que se assemelham à realidade vivida em vários locais do país. Outro estudo importante é o de Silva (2009), “Trabalho e população em situação de rua no Brasil", reprodução de sua dissertação de mestrado que debate as mudanças no mundo moderno do trabalho e esse segmento social entre os anos de 1995-2005, abordando esse fenômeno como uma síntese de várias determinações da sociedade capitalista.

Para finalizar, é interessante observar que, no âmbito dos estudos da linguagem, encontramos pesquisas a partir de diferentes abordagens teóricas, mas nenhuma a partir da perspectiva da Análise da Conversa. Com base na análise crítica do discurso, é possível encontrar estudos sobre situação de rua sendo desenvolvidos na esfera da Rede Latino-americana de Análise do Discurso da Pobreza (REDLAD) ${ }^{16}$. Também encontramos trabalhos sobre esse grupo social em estudos amparados teórico-metodologicamente na Análise do Discurso francesa. Como, por exemplo, o estudo de Lysardo-Dias (2016), em que a autora analisa o uso das novas tecnologias da web por moradores em situação de rua como expressão para narrativas autobiográficas, que servem como testemunho de experiências individuais representativas da situação de exclusão, pelas quais muitas dessas pessoas passam.

\footnotetext{
${ }^{16}$ A respeito, ver Pardo (2008), Montecino (2010), Coracini (2011) e Resende e Marshese (2001).
} 


\section{3}

\section{A análise da Conversa}

Esta tese tem como base os pressupostos teóricos da Análise da Conversa (AC) fundada por Harvey Sacks e amplamente desenvolvida com a colaboração de Emanuel Schegloff e Gail Jefferson (Sacks, 1992; Sacks; Shegloff; Jefferson, 1974), com base na etnometodologia de Harold Garfinkel (1967). Segundo Heritage (1999), a AC talvez seja a corrente que mais se ocupa da análise direta da ação social, dentre todas as correntes de pesquisa da etnometodologia.

A Análise da Conversa estuda a ação humana, por meio da análise da falaem-interação, situada no aqui e agora da interação, com o objetivo de revelar os procedimentos implícitos e a organização do raciocínio prático da produção de fala, em que o nível micro é visto como universo de significação da ação social. Uma vez que as interações são socialmente organizadas/estruturadas, por meio da AC, é possível fazer descrições dos métodos que os interagentes utilizam para agir interacionalmente, por exemplo, para dar explicações; cumprimentar/saudar; fazer um pedido; solicitar algo-responder a uma solicitação; aconselhar; fazer alguma oferta - aceitá-la ou recusá-la, etc. Desta maneira, "ações realizadas por conversas são feitas em turnos de fala" (Shegloff, 2007, p.3).

De acordo com Shegloff (2007, p.1), "uma das organizações mais fundamentais da prática de fala-em-interação é a organização da tomada de turnos" da conversa. Em Sacks; Schegloff e Jefferson (2003 [1974]), é possível encontrar uma descrição detalhada do modelo dessa organização sistemática, que os atores sociais usam para tomar o turno de fala, por meio de fatos amplamente observáveis em conversas, mediante o estudo de gravações em áudio de conversas de ocorrência natural. Esses autores (idem, ibidem, p.1) nos mostram que esse modelo é “caracterizado, no mínimo, como gerenciado localmente, administrado pelas partes, controlado interacionalmente e sensível a ajuste ao interlocutor (recipient desing)" e destacam os seguintes fatos gerais:

(1) A troca de falante se repete, ou pelo menos ocorre (cf. $\S 4.1$, abaixo).

(2) Na grande maioria dos casos, fala um de cada vez (cf. § 4.2).

(3) Ocorrências de mais de um falante por vez são comuns, mas breves (cf. § 4.3). 
(4) Transições (de um turno para o próximo) sem intervalos e sem sobreposições são comuns. Junto com as transições caracterizadas por breves intervalos ou ligeiras sobreposições, elas perfazem a grande maioria das transições (cf. $\S 4.4$ ).

(5) A ordem dos turnos não é fixa, mas variável (cf. § 4.5).

(6) O tamanho dos turnos não é fixo, mas variável (cf. § 4.6).

(7) A extensão da conversa não é previamente especificada (cf. § 4.7).

(8) O que cada um diz não é previamente especificado (cf. § 4.8).

(9) A distribuição relativa dos turnos não é previamente especificada (cf. § 4.9).

(10) O número de participantes pode variar (cf. § 4.10).

(11) A fala pode ser contínua ou descontínua (cf. § 4.11).

(12) Técnicas de alocação de turno são obviamente usadas. Um falante corrente pode selecionar um falante seguinte (como quando ele dirige uma pergunta à outra parte) ou as partes podem se auto-selecionar para começarem a falar (cf. § 4.12).

(13) Várias 'unidades de construção de turnos' são empregadas; por exemplo, os turnos podem ser projetadamente a 'extensão de uma palavra' ou podem ter a extensão de uma sentença (cf. § 4.13).

(14) Mecanismos de reparo existem para lidar com erros e violações da tomada de turnos; por exemplo, se duas partes encontram-se falando ao mesmo tempo, uma delas irá parar prematuramente, reparando, assim, o problema (cf. § 4.14). (Sacks; Schegloff e Jefferson, 2003 [1974], p.13-14)

Em seguida, eles trazem observações importantes a respeito desses fatos gerais: a) sistemas de troca de falas que não seja a conversa cotidiana costumam ter diferenças prontamente perceptíveis, como o tamanho e a ordenação dos turnos, diferenças que sugerem o funcionamento de diferentes sistemas de troca de falas; b) a organização social da troca de turnos distribui os turnos entre as partes, de forma que eles são valorizados, procurados ou evitados. Depois seguem para a descrição detalhada da sistemática elementar da troca de turnos.

Outra questão crucial no estudo da fala-em-interação na $\mathrm{AC}$ é a sequencialidade, propriedade constituinte fundamental das ações sociais e da interação (Sacks, 1992). Como afirma Shegloff (2007), a base da fala-em-interação é melhor examinada com relação ao curso das ações do que à topicalidade (tópico/tema/assunto) da conversa, isto porque os atores sociais se orientam para sequências de ações em seus turnos de fala. Ao pensarmos nesses turnos em termos de ação, estamos lidando com cursos de ação. Isso leva o autor a fazer uma importante distinção entre "organização sequencial" e "organização de sequências" (Shegloff, 2007, p.1-3).

Segundo o autor, a organização sequencial é o termo mais geral, usado para se referir a qualquer tipo de organização que diz respeito ao posicionamento relativo das elocuções ou ações, uma após outra. Dessa forma, Shegloff (2007) nos mostra que a tomada de turnos é um tipo de organização sequencial porque diz respeito à relativa ordenação dos interagentes, de Unidades de Construção de Turnos (UCT) 
e de diferentes tipos de elocuções, bem como a Organização Estrutural Global também é um tipo de organização sequencial; por alusão à sua forma, alguns tipos de ações/elocuções são posicionados no início de uma conversa (por exemplo, saudações), enquanto outros no final de conversas (por exemplo, arranjos, despedidas). Por sua vez, a organização de sequências é um termo mais específico, por se tratar de um dos tipos de organização sequencial, que tem como escopo a organização de cursos de ação desempenhados na fala, sucessões ou sequências de ações ou movimentos coerentes, ordenados e significativos ou sequências de ações ou movimentos.

Assim, é principalmente através das sequências interacionais de fala que se torna possível identificar quais ações os/as interagentes estão engajados/as em realizar. Como apontam Loder, Salimen e Müller (2008), somente conseguimos analisar e interpretar o significado das ações por meio das sequências interacionais; por exemplo: só conseguimos diferenciar um “oi" que realiza uma saudação de um “oi" que tem por função a solicitação de repetição (início de reparo), observando a sequência em que essa elocução foi utilizada. Cada turno realizado, portanto, traz uma ação orientada para a ação produzida anteriormente, influenciando a ação a ser desenvolvida no turno subsequente, daí o termo sequencialidade. Dessa maneira, a unidade básica da construção de sequências é o par adjacente, recurso para construção de sequências abordado na próxima seção.

\section{1.}

\section{Pares adjacentes}

Sacks (1992) aborda a questão da sequencialidade e introduz também um tipo de objeto organizacional da conversa: pares de elocuções, especificando os pares adjacentes, que se referem às ações interacionais que vêm em pares. Isto é, uma ação em um primeiro turno de fala projeta outra ação considerada relevante para os participantes no próximo turno.

Shegloff (2007, p.13) faz referência ao texto de Sacks (1992) e a outros autores que abordam os recursos dos pares adjacentes. Além de analisar a forma básica, não expandida, o autor elenca as características de um par adjacente:

\section{(a) ser composto por dois turnos;}


(b) ser realizado por diferentes interagentes;

(c) ser colocado de maneira adjacente, ou seja, um após o outro;

(d) possuir dois turnos relativamente ordenados, isto é, são diferenciados em "Primeira Partes dos Pares" (PPP) ${ }^{17}$ e "Segunda Parte dos Pares" (SPP) ${ }^{18}$. As PPP são tipos de elocução/ação, como pergunta, pedido, oferta, convite, anúncio, etc. - tipos que iniciam o turno e projetam a necessidade de uma ação responsiva. As SPP são tipos de elocução/ação, como resposta, concessão, rejeição, aceitação, recusa, concordância/discordância, reconhecimento, etc. - tipos que são sensíveis à ação de um turno anterior;

(e) ser de tipos específicos, ou seja, nem toda segunda parte do par pode seguir-se de forma adequada a qualquer parte do primeiro par: cada PPP será seguida de uma SPP específica adequada à PPP. Os pares adjacentes compõem tipos de pares como, por exemplo: saudação-saudação, pergunta-resposta, ofertaaceite/recusa, e assim por diante. Para compor um par adjacente, a PPP e a SPP vêm do mesmo tipo de par. Considere as PPP "Olá", ou "Você sabe que horas são?", ou "Você gostaria de uma xícara de café?", e tais SPP: "Oi", ou "Quatro horas", ou "Não, obrigado", respectivamente (Shegloff, 2007, p.13-14).

Após, Shegloff (2007) ratifica a regra de operação do par adjacente, de acordo com a qual, dada a PPP, em sua finalização, um próximo falante (geralmente, alguém selecionado como próximo falante pela PPP) deve começar a falar e produzir uma SPP do mesmo tipo de par. Essa regra também é chamada de relevância condicional (cf. Shegloff, 1968). Loder et al. (2008) afirmam que, embora a relevância condicional sintetize a relação entre as duas partes do par adjacente, essa noção também está presente na organização de sequências maiores.

Segundo Shegloff (2007), nenhuma das características do par adjacente apresentada (a-e) é rígida ou invariável, e todas elas requerem alguma elaboração, as sequências baseadas em pares adjacentes podem vir a ter mais de dois turnos (embora ainda duas partes básicas); podem ser separadas por conversas intervenientes (caso das expansões abordadas pelo autor); podem ocasionalmente ser articuladas pelo mesmo interagente, como forma de transmitir duas "vozes", a exemplo de quando a pessoa fala consigo mesma e responde (embora esse uso se

\footnotetext{
17“first pair parts" (FPPs).

18“"second pair parts" (SPPs).
} 
baseie na propriedade básica de que a PPP e a SPP são produzidas por interagentes diferentes); podem ser usadas, em alguns tipos de elocuções, tanto como PPP quanto como SPP (por exemplo, a reclamação, que pode ser usada não só para iniciar uma sequência, mas também em resposta a uma consulta; uma oferta pode ser uma PPP, mas também uma resposta a uma reclamação), e, sob circunstâncias específicas, podem ser articuladas como PPP e SPP ao mesmo tempo, a exemplo de quando alguém the pede para repetir uma pergunta e você faz - produzindo, assim, uma SPP, ao conceder seu pedido, e um PPP, já que, ao fazê-lo, você re-fez sua pergunta), entre outros.

Nos excertos a seguir, vemos dois exemplos simples de pares adjacentes, do corpus desta tese:

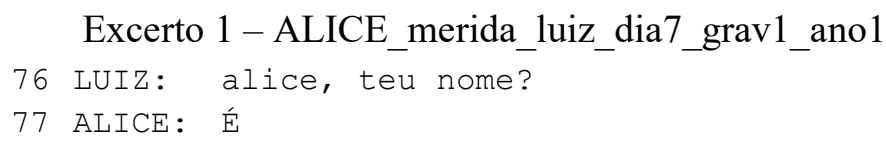

No primeiro excerto, no primeiro turno, o voluntário Luiz faz um pedido de confirmação à voluntária Alice, que, em segundo turno, responde com uma confirmação. No segundo, a voluntária Merida cumprimenta os assistidos, na PPP, e tem como SPP o mesmo cumprimento. Aqui, podemos ratificar algumas características dos pares adjacentes: eles se dão em dois turnos; são realizados por interagentes diferentes; ocorrem em posição adjacente; por meio de falas sucessivas; de tipos específicos e composição de primeira e segunda partes.

Os pares adjacentes, portanto, são formados por duas elocuções, em que a PPP, geralmente direcionada a um/a interagente selecionado/a, é seguida da SPP, que se constitui como um retorno à primeira parte e apresenta uma adequação sequencial como regra de operação, embora haja casos em que essa regra pode não ser seguida. Esses casos, em que a regra não ocorre, costumam causar estranheza por parte do primeiro interagente, que pode produzir uma solicitação de reparo ou, simplesmente, insistir em sua fala anterior, até que haja uma produção que leve em consideração a fala anterior. Trata-se de situações interacionais em que o segundo falante pode estar tentando não ter que produzir a SPP e, por isso, não apresentar 
em sua fala ligação com o turno anterior, como veremos alguns exemplos em nossos dados. Essas afirmações podem ser observadas no excerto a seguir, que faz parte do nosso corpus e é parte da interação entre uma voluntária da ONG estudada e uma assistida:

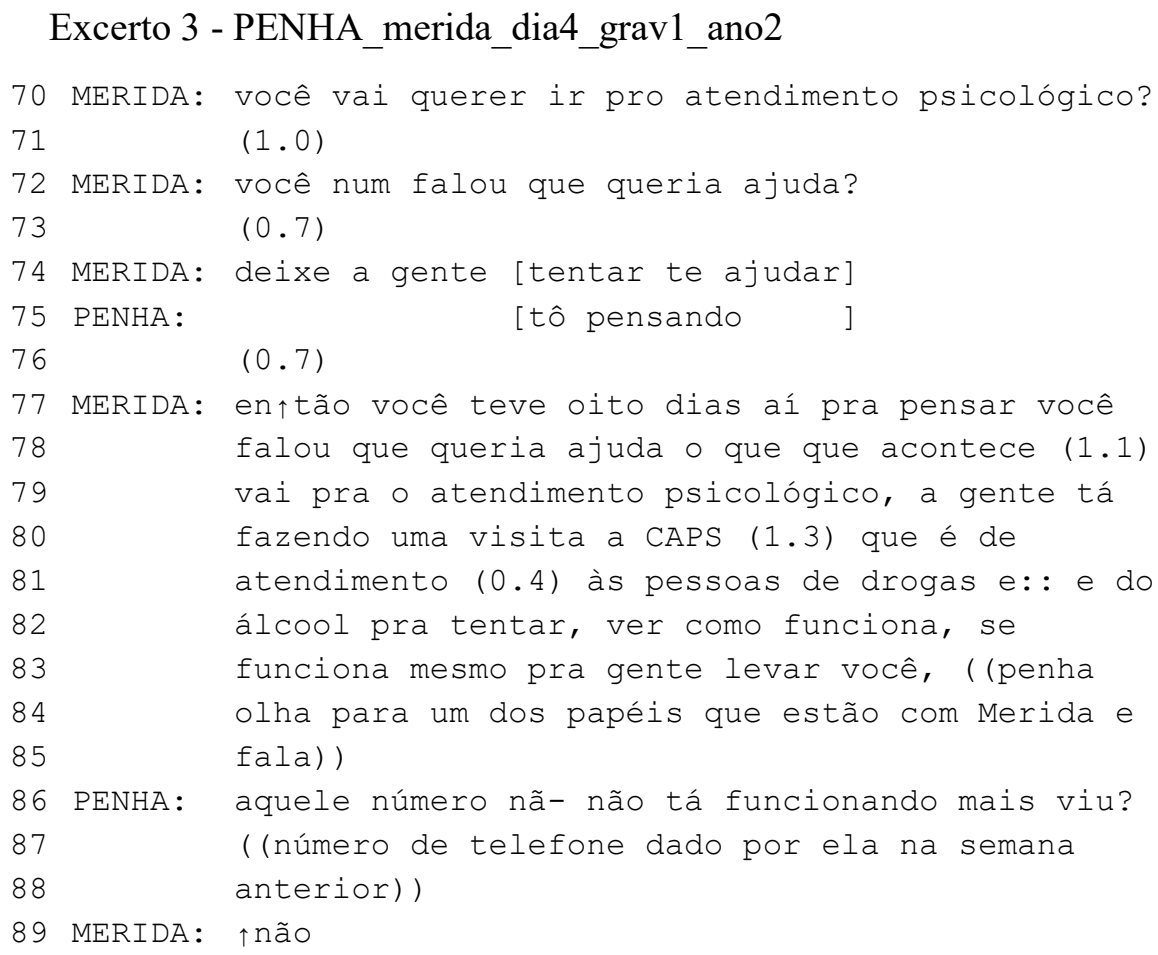

Vemos, na linha 70, uma pergunta que tem como função a retomada de uma oferta e não obtém resposta imediata (1.71), o que gera reformulações por parte de Merida (1.71), que só obtém retorno após a reformulação no formato de pedido "deixe a gente [tentar te ajudar]" (1.74), de forma imprecisa "[tô pensando]" (1.75), seguida de insistência (1.77-83) com uma série de ações propositivas, que são ignoradas por meio da mudança de tópico de Penha, ao fornecer uma informação nova que nada tem a ver diretamente com as ações em primeira posição da voluntária Merida (1.86).

As implicações interacionais desse excerto são discutidas de forma detalhada na seção 8.4.2.2. No entanto, nos interessa mostrar a possibilidade de, por opção, o falante em segunda posição ignorar as PPP, embora essa não seja uma conduta interacional comum para vários outros contextos. Além disso, no mesmo excerto, vemos que a informação fornecida por Penha (1.86), não é ignorada por Merida, que 
faz um pedido de confirmação, em sequência (1.89), que também poderia ter fornecido algum marcador de recebimento simples da informação.

Shegloff (2007) ratifica que, uma vez registrada, em interações, a presença robusta de sequências totalmente constituídas por um par adjacente mínimo, simples e básico, é necessário observar, em seguida, que muitas sequências envolvem expansão dessa unidade básica (de base). Tais expansões se constituem de turnos adicionais das partes, além dos dois que compõem a versão mínima da sequência, e ocorrem nos três lugares possíveis em uma sequência de dois turnos: antes da primeira parte do par, chamadas de pré-expansões; entre a primeira parte e a segunda parte do par projetado, conhecidas como expansões por inserção (ou inseridas); e depois da segunda parte do par, quando são chamadas de pósexpansões. É necessário observar, contudo, que cada tipo de expansão ocorre em par adjacente. Os tipos de expansão descritos podem ser ilustrados no quadro a seguir:

Quadro 3: Possibilidades de expansão do par adjacente

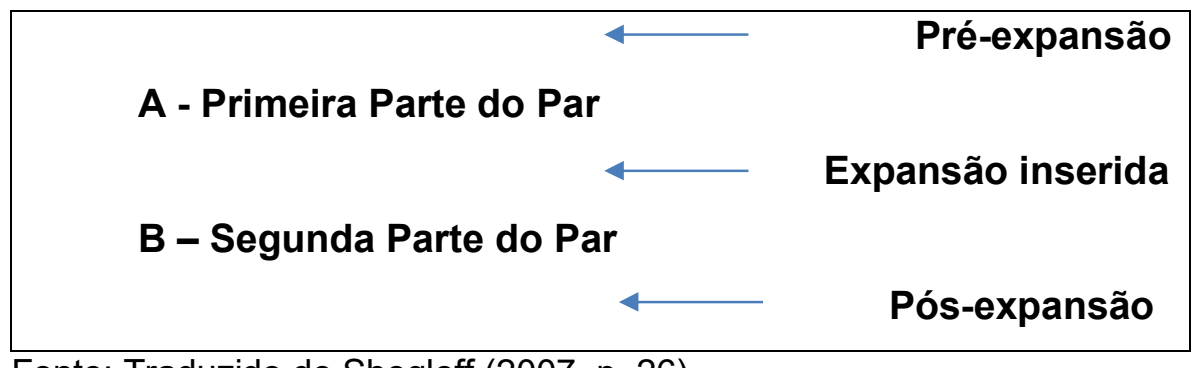

Fonte: Traduzido de Shegloff (2007, p. 26).

Focaremos aqui o tipo de expansão que mais chamou atenção em nossos dados: as pré-expansões. Estas, em praticamente todas as ocorrências, são construídas a partir de pares de proximidade - portanto, regularmente chamadas "pré-sequências" (Shegloff, 2007). Como o nome indica, são sequências que vêm antes das sequências base, reconhecidamente "pré", isto é, antecessoras da sequência principal. Mais especificamente, são um primeiro par de um tipo específico: um convite, um pedido, um anúncio, uma oferta.

As pré-sequências são preliminares e projetam tais PPP iminentes de pares específicos. Por exemplo: pré-convites, pré-pedidos, pré-anúncios e pré-ofertas. Uma pré-sequência tem duas características importantes: torna relevante a 
ocorrência de uma ação responsiva a partir de uma SPP e, por conta disso, verifica a possibilidade de prosseguir com a PPP de base. As SPPs das pré-sequências podem ser do tipo encorajadoras - que levam o produtor da PPP da pré-expansão a se orientar para a produção da PPP base - ou, ao contrário, ser do tipo bloqueadoras, ao projetarem o bloqueio da realização da PPP base. Dessa forma, as ações responsivas de uma pré-sequência podem se configurar favoráveis ou não a uma sequência de base.

É importante destacar que, de acordo com Shegloff (2007), as présequências parecem, em grande parte, serem projetadas para evitar vários tipos de problemas na sequência que uma PPP em perspectiva poderia iniciar. Dessa maneira, pré-sequências parecem construídas para antecipar e contornar é rejeição ou desacordo, ou, em termos mais específicos, "respostas despreferidas"19/desalinhadas. Assim, pré-sequências contribuem para evitar um possível "fracasso" da PPP de base pretendida, por exemplo, pré-ofertas podem verificar a possibilidade de interesse do/a destinatário/a ou mesmo a viabilidade para aceite da oferta pretendida criando a possibilidade de contornar uma possível rejeição.

\section{2 .}

\section{Organização de preferência}

A noção de organização de preferência está diretamente relacionada à questão dos pares adjacentes. Pomerantz (1984) já havia descrito o sistema dessa organização, em que ações preferidas são fornecidas sem demora, e em formato direto. Em contrapartida, a autora caracteriza as ações despreferidas como aquelas que são dadas com hesitações, que podem ocorrer por meio de pausa antes de uma resposta, de um desordenamento ou de sequências inseridas. Comumente, com prefácios, como o uso de marcadores discursivos, por exemplo: “ah”, “bom”, "olha", isto é, ações desse tipo possuem um trabalho interacional maior que as ações preferidas.

\footnotetext{
${ }^{19}$ Na próxima seção abordamos especificamente a questão da organização de (des)preferência.
} 
Pomerantz e Heritage (2013, p. 2010) mostram que a organização de preferência pode ser encontrada tanto em ações iniciais quanto em ações responsivas e afirmam que

A ideia central de preferência é a de que os participantes sigam princípios, frequentemente implícitos, quando atuam e reagem a uma variedade de situações interacionais. No entanto, apesar do núcleo comum, o conceito de preferência é usado para descrever diferentes tipos de princípios que operam em diferentes domínios e envolvem diferentes ordens e tipos de restrições (Pomerantz; Heritage, 2013, p. 210).

O autor e a autora nos mostram que os princípios da organização preferencial desempenham um papel na produção e interpretação das PPP e SPP, embora as pesquisas sobre esse tipo de organização para iniciar ações (PPP) tenham sido menos desenvolvidas e foquem mais em estratégias de "evitação". Nesse estudo, é fornecido um mapa aproximado de como os participantes orientam esses princípios em alguns domínios da interação, revisando as pesquisas já existentes na literatura da Análise da Conversa, com foco em três grandes domínios: princípios de preferência relacionados a referências; relacionados às ações da conversa (tanto ações de resposta quanto iniciais); e às circunstâncias nas quais vários princípios de preferência conflitantes operam e como eles são gerenciados.

Shegloff (2007), por sua vez, reserva o capítulo cinco para discutir sobre a organização de (des)preferência. É importante destacar que essa organização é uma característica sociointeracional das sequências e de orientações a elas. Trata-se de uma relação estrutural de partes de uma sequência, não tendo relação psicológica com a real preferência, do senso comum, dos/as interagentes- seja quem realiza a PPP, seja seu/sua interagente. Como defende o autor (2007), não é uma questão dos seus motivos, desejos ou gostos pela primeira parte do par ou segunda, embora, em qualquer caso - talvez, até na maioria deles -, a preferência sequencial e as inclinações individuais possam coincidir.

De acordo com Shegloff (2007), a questão-chave no estudo da (des)preferência diz respeito ao alinhamento de como uma segunda ação está para a primeira. Esse alinhamento é de dois tipos, que podemos chamar de "mais" $(+)$ e "menos" (-). Para ofertas e convites, "aceitar" parece ser a ação mais apta para a resposta +, e "declinar" junta-se a "rejeitar" como mais apropriado para a resposta -. A resposta +, então, incorpora um alinhamento com a parte do primeiro par, e a resposta -, um distanciamento dela. No entanto, existem complicações e exceções 
a essa estrutura geral de preferências: apesar de o aceite ser a resposta preferida das ofertas, essa pode ser uma resposta contingente, condicionada ao item oferecido e ao contexto. Algumas ofertas podem ser mais convincentemente entendidas como tendo rejeições preferenciais, tal qual, por exemplo, a oferta "Você gostaria do último pedaço de torta?”. Essa oferta pode ser denominada "pró-forma", e terá rejeição como resposta preferida.

No que diz respeito à organização de preferência às SPP de ofertas, é importante destacar que as possíveis ações responsivas a elas, aceite ou recusa, também possuem organização preferencial, pois, como nos mostra Schegloff (2007, p. 59), os tipos alternativos de SPP que uma PPP faz relevantes não são equivalentes ou igualmente valorizados, ou seja, os tipos de SPP não são "alternativas simétricas"20 (Schegloff e Sacks, 1973: 314). Isso se dá porque, como argumenta o autor, as sequências são o meio para a obtenção de alguma ação realizada (PPP), e, quando a resposta a essa primeira parte do par incorpora ou favorece a promoção ou a realização projetada, a SPP é considerada preferida.

Uma das questões que analisaremos nesta tese é como os aceites e as recusas às ofertas são formatados/as e quais as implicações interacionais dessas respostas às ofertas. Essa análise pode não só contribuir para uma descrição dessa ação, como também ajudar os/as voluntários/as a conhecer melhor a cultura do grupo e a rever os modos de realizar oferecimentos naquele contexto.

\section{3.}

\section{A ação da oferta}

São muitas as possibilidades de ações realizadas por meio da linguagem, mas uma das centrais nesta tese é a oferta, classicamente, seguida de aceite ou recusa. Por conseguinte, nesta seção, nos debruçamos sobre essa ação.

A maior parte da literatura traz a oferta no mesmo grupo de ações como pedido ou convite, fazendo distinções entre elas. Dessa maneira, essas outras ações também são citadas nesta seção, quando os/as autores/as apresentados/as aqui as analisam conjuntamente, embora nosso principal enfoque desta seção continue sendo a oferta. Couper-Kuhlen e Selting (2018), por exemplo, colocam as ofertas

20 "Symmetricalalternatives". 
no mesmo grupo dos pedidos, como pertencentes a uma família de ações que ErvinTripp tem chamado de movimentos de controle ${ }^{21}$ : ações da conversa por meio das quais um/a falante tenta influenciar as atividades do/a interagente.

Em consonância ao apresentado por Shegloff (2007), Couper-Kuhlen e Selting (2018) ressaltam que as ações iniciais de oferta e de pedido têm em comum o fato de que elas fazem tipos similares de ação de alinhamento $(+)$ e de desalinhamento (-), podendo a oferta ser aceita ou recusada e o pedido, cumprido ou recusado. As autoras mostram, a partir de observações iniciais, que as ofertas na conversa cotidiana, em inglês, especialmente quando feitas com o formato "você quer X", são aceitas com relutância - isso quando o são. Por outro lado, os pedidos têm maior probabilidade de receber respostas positivas (em conformidade). Os ingleses, ao fazerem pedidos, sinalizam verbalmente que cumprirão um pedido de baixo custo, quando dizem "ok/certo/claro", ou comprometem-se, explicitamente, a realizar uma ação de alto custo, quando adiam, dizendo "eu vou fazer X/ Y”, em que $\mathrm{X}$ e $\mathrm{Y}$ representam uma reutilização ou uma paráfrase do texto do pedido. Descrições de outras línguas indicam que esse é o padrão mais difundido. As autoras ratificam que, nos casos de recusa, fatos ou circunstâncias objetivas são relatados como uma maneira de afirmar, implicitamente, que não há necessidade do que o/a ofertante está propondo. Elas mostram que foram observadas práticas recorrentes em relação à recusa: quando a oferta é feita em um formato que enfatiza a necessidade do destinatário, a rejeição, muitas vezes, evidencia a sua não necessidade, e não se realiza apenas por meio de um "não".

Shegloff (2007) coloca as ofertas no mesmo grupo dos pedidos e dos convites, pois, segundo ele, elas formam um conjunto de ações que possuem tipos de sequência associados e pode ser difícil de distinguir umas das outras. Convites, por exemplo, podem, muitas vezes, parecer uma subclasse particular de ofertas, com similaridade em vários aspectos, inclusive em suas pré-sequências, ainda que as formas das elocuções e a colocação do tipo de sequência em sua ocasião social possam diferir. Assim como pessoas que desejam fazer convites podem, por meio de pré-convites, buscar evidências de sua recusa ou aceitação - caso resolvam colocá-los em prática -, da mesma forma, é possível que indivíduos que tenham

21 "Control moves". 
algo a oferecer avaliem se sua oferta será bem-vinda ou não, de modo que o oferecimento real pode ser subordinado ao resultado dessa ação, feita por meio da sequência de pré-oferta, como já apresentado na seção dos pares adjacentes.

Couper-Kuhlen e Selting (2018) nos mostram, ainda, que o que distingue ofertas e pedidos de outras ações de movimentos de controle é a preocupação, nesses primeiros, com a transferência de um objeto ou serviço. A associação de ambas as ações pelas autoras é feita também, porque, quando bem-sucedidas, elas conduzem ao mesmo resultado, e uma tem sido vista como alternativa à outra, embora não sejam alternativas simétricas. Isso porque, quando se trata de coisas iguais, afirma-se que os/as interagentes preferirão realizar a transferência de um objeto ou serviço por meio de uma oferta, não de um pedido. Evidências disso vêm de pesquisas de $\mathrm{AC}$ que demonstram que:

a) sequências de pré-pedido são frequentemente usadas para buscar ofertas;

b) as ofertas surgem no início da sequência, ocasionalmente através da conclusão de turnos antecipatórios, mas os pedidos são adiados e concluídos apenas se não surgir nenhuma oferta; c) os pedidos, geralmente, são mascarados como ofertas (Lerner 1996b; Schegloff 2007 a p. 83-4); (Couper-Kuhlen e Selting, 2018, p. 249).

É válido destacar que uma grande diferença entre o pedido e a oferta diz respeito a quem é beneficiado/a com a realização da ação futura do/a outro/a. No caso do pedido, geralmente quem pede é quem precisa da ação ou de algo, enquanto, na oferta, o/a beneficiado/a é quem recebe.

Para finalizar esta seção, apresentaremos o estudo de Curl (2006), que analisa ofertas de ajuda produzidas em interações de ligações telefônicas, em língua inglesa, oriundas de gravações feitas nos Estados Unidos e na Inglaterra. Essa oferta de ajuda é a ação de oferecimento de um/a falante (o/a ofertante) para satisfazer algo que o/a destinatário/a quer ou precisa, ou para ajudar na resolução de uma dificuldade ou infortúnio vivido pelo/a destinatário/a, após este/a ter demonstrado ou não que estaria necessitando de ajuda. Os vários desejos, necessidades e experiências ruins, relacionados ao ato de ofertar, foram indexados com o substantivo coletivo "problema" em todo seu artigo.

Segundo o autor (2006), seu estudo segue a metodologia da Análise da Conversa informada pela linguística ${ }^{22}$, talvez mais conhecida como linguística

\footnotetext{
22 “Linguistics-informed Conversation Analysis, Walker, 2004: 18-20” (Curl, 2006, p. 1258).
} 
interacional (p. 1258). Embora a análise faça referência a determinadas restrições sequenciais resultantes dessas interações (isto é, aberturas de chamada e fechamentos de chamada), a análise das várias ofertas produzidas em contextos face-a-face sugere que elas seguem um padrão semelhante. Para a atividade de oferecer assistência a algum problema, são vistos diferentes tipos de construções sintáticas utilizadas na oferta.

Curl (2006) defende que fazer uma oferta é uma atividade bastante comum na conversa cotidiana, e que ela pode ter diferentes formatos gramaticais. Em seu estudo, foram identificados certos formatos sintáticos dentro de determinados grupos de interações. Não buscaremos, aqui, fazer uma descrição exaustiva dos fenômenos observados nas interações analisadas por Curl (2006), mas, ao invés disso, descrever suas divisões, bem como as estruturas sintáticas características das partes. As ofertas apresentadas dividem-se em dois grupos: o primeiro é nomeado por ele de "ofertas em sequências de ligações motivadas pelo problema" 23; e o segundo, composto por dois subgrupos, é nomeado de "ofertas geradas internacionalmente". Cada um desses dois grupos possui características e estruturas lexicais específicas as quais passamos a descrever.

No primeiro grupo (ofertas em sequências de ligações motivadas pelo problema), as ofertas são feitas pela pessoa que liga e são posicionadas na seção de abertura, depois da identificação e saudação inicial. Geralmente, passa por uma referência a uma conversa anterior ou a um conhecimento adquirido sobre o problema daquele/a que recebe a ligação, possivelmente vindo de uma terceira pessoa. Sendo assim, as ofertas não são geradas interacionalmente, no sentido usado em Sacks (1992).

As sequências deste grupo possuíam três partes: além da oferta, já referida, há também a abertura e a contextualização ${ }^{24}$. Na abertura, poderia aparecer um account, para justificar a realização da ligação, ou poderia ser identificada a presença de expressões como "veja..." (look) ou "escuta..." (listen), utilizadas para seguir adiante com a conversa, após o ato de abertura. Na parte da contextualização, a pessoa que liga explica como e o que ela sabe sobre o problema de quem recebe a ligação, começando a projetar a oferta que está por vir.

\footnotetext{
${ }^{23}$ Offers in reason-for-calling sequences.

${ }^{24}$ Background.
} 
As ofertas analisadas nesta categoria assumiram um mesmo padrão sintático, que foi denotado por [[se X]Y], isto é, começa com a elocução 'se'-, que é seguida por uma elocução principal. Em uma das transcrições analisadas no texto e usadas para exemplificar esse formato, Leslie liga para Philip, cuja mãe acaba de falecer. Após realizar as outras partes desse tipo de oferta, Leslie produz o padrão sintático mencionado pelo autor, que foi simplificado, pelo próprio autor, como “[[se tiver algo que possamos fazer] é só nos dizer]” (Sacks, 1992, p. 1264)²5.

$\mathrm{Na}$ sequência do artigo, há a descrição das ofertas geradas interacionalmente, ou seja, o segundo grupo já referido, começando com as ofertas elaboradas a partir de conversas relevantes. Nesse caso, a oferta é feita em um ponto que é sequencialmente e temporariamente distanciado do problema. E o problema, em si, é latente ou possui "existência meramente potencial" na conversa prévia (Curl, 2006, p. 1259).

Além disso, o turno da oferta é inserido no fechamento e sua estrutura sintática se configura como uma pergunta polar do tipo sim/não, no formato Você Quer (que eu faça) algo ${ }^{26}$, também referida como ofertas $\mathrm{VQ}^{27}$. Por meio da utilização dessa forma sintática, os/as ofertantes mostram que estão propondo fornecer algo que entendem ser necessário ou desejado pelos seus destinatários. Esses tipos de ofertas condicionam o destinatário "a fornecer uma resposta de confirmação ou rejeição no próximo turno" (Raymond, 2003, p. 944). Esse formato sintático torna os destinatários agentes de um querer. Apesar de essas ofertas VQ terem variações, o que elas têm em comum é justamente o primeiro plano do destinatário como o sujeito da elocução.

Para ilustrar esse padrão sintático, trazemos uma simplificação da elocução produzida por uma falante, Claire, enquanto ela fala com sua amiga Zoe ${ }^{28}$. Claire e Zoe estão conversando sobre os eventos que aconteceram e os eventos que estão por vir (party bridge=jogo de bridge), dos quais Zoe será anfitriã. A oferta é feita dentro do turno de fechamento da chamada, após Claire já ter feito um préfechamento, ao dizer "até mais, vejo você sábado", que é seguido por um acréscimo feito por Zoe, que diz "sábado à noite". Neste momento, Claire faz a oferta: "Você

\footnotetext{
${ }^{25}$ [[if's anything we can do] let us know] (p.1264).

${ }^{26}$ DYW (Do You Want (me to) X).

${ }^{27}$ DYW offers.

${ }^{28}$ Essa simplificação é baseada no excerto 6 de Curl (2006, p.1266).
} 
quer que eu traga as cadeiras?". O interessante aqui é que essa estrutura ocorre aproximadamente quatro minutos e meio depois de Zoe pedir para Claire trazer tally sheets para o jogo de bridge, pedido que foi aceito por Claire, mas, até então, nada havia sido dito sobre trazer cadeiras.

$\mathrm{O}$ autor menciona, ainda, vale destacar, que as sequências [[if $\mathrm{X}] \mathrm{Y}]$ são formatadas para serem seguidas por "muito gentil da sua parte" ou algum tipo de agradecimento, enquanto o VQ é seguido por sim ou não.

No banco de dados de ofertas do estudo de Curl (2006), as ofertas VQ são encontradas somente quando o problema que eles se propõem a remediar ou a resolver é inferido, quando ele não é abertamente exposto como tal pelo eventual destinatário da oferta. Cumpre destacar, porém, que nem todas as ofertas geradas interacionalmente surgem a partir de indução de um falante de um problema na fala anterior, que é o segundo grupo gerado internacionalmente: II) ofertas em resposta a problemas compartilhados. Este tipo de oferta pode ser realizado tanto por quem faz a chamada, quanto por quem a recebe. A pessoa que possui o problema passa a ser o/a receptor/a da oferta, a qual é feita no momento em que o problema é compartilhado, ou muito próximo desse momento, podendo ser realizadas as ofertas não apenas em potenciais seções de fechamento.

Dos seis fragmentos utilizados pelo autor para ilustrar esse último tipo de oferta, em cinco, a oferta é projetada de tal forma que o/a ofertante é o/a agente da atividade oferecida (por exemplo, “eu a levo", "eu te levo”, “o que posso trazer").

O padrão sintático deste tipo de oferta é mais diversificado que o das demais. Ainda assim, podem-se encontrar alguns padrões, um deles é que as ofertas desse grupo nunca serão no formato VQ. Esse fenômeno é bem ilustrado pelo autor mediante o único fragmento em que esse padrão ocorre. Nele ${ }^{29}$, Emma está falando com Nancy sobre uma operação que realizou em seu dedão, como um motivo para rejeitar o convite de Nancy para ir ao shopping. Embora Emma recuse o convite, ela revela o desejo em adquirir um par de $\operatorname{chinelos}^{30}$, mas afirma que ir ao shopping poderia não ser bom para ela. Após um pouco de conversa, Nancy, enfim, faz a oferta, a qual possui o formato VQ (“bem, você quer..."), mas não conclui a frase com (que eu pegue um par para você). Após um pouco mais de conversa, ela faz

29 Essa simplificação é baseada no excerto 16 de Curl (2006, p. 1274).

${ }^{30}$ little slippers. 
um reparo de formato sintático (quero dizer... ${ }^{31}$ ); reiniciando a oferta, desta vez com "posso te trazer alguma coisa ${ }^{32}$ ", faz um reparo refazendo a oferta.

Em suma, três grupos de ofertas de assistência foram produzidas em conversas ao telefone e descritas por Curl (2006): 1) ofertas em que as ligações são realizadas motivadas pelo problema, duas geradas interacionalmente, 2) ofertas elaboradas a partir de conversas relevantes e 3) ofertas em resposta a problemas compartilhados. O autor (2006) nos mostra que as distintas construções sintáticas utilizadas nessas ofertas estão relacionadas à situação social e à posição sequencial em que esse oferecimento é feito. Dessa forma, esses oferecimentos são compreendidos pelos/as interagentes também pelo tipo de atividade na qual eles/elas estão engajados/as.

No caso desta tese, nos capítulos sete e oito, descrevemos o formato dos tipos de ofertas-aceite/recusa analisados, mas com foco na organização de (des)preferência e suas implicações interacionais.

\section{4 .}

Organização Estrutural Global das interações

As interações possuem Organizações Estruturais Globais passíveis de serem descritas. Isso se torna possível porque a fala é também organizada estruturalmente, isto é, em sequências múltiplas de turnos de ações. Desta forma, essa Organização Estrutural Global (OEG) é uma questão cara à Análise da Conversa, o que pode ser reforçado por meio da metáfora de Robinson (2013, p. 257), ao afirmar que, se a disciplina Análise da Conversa fosse uma árvore, o tópico da organização da estrutura geral representaria um dos seus primeiros anéis de crescimento. Apesar disso, o autor afirma que, embora essa tenha sido uma questão estudada por Schegloff (1967), desde sua tese, e Sacks tenha dedicado várias de suas aulas, no inverno de 1970, com o título "Organização estrutural global da conversa ${ }^{33}$ ", a estrutura geral recebeu pouca atenção desde aquela época e, por isso, ainda não era bem compreendida, no período em que escrevia seu texto.

\footnotetext{
31 "I mean".

32 "can I get you something” (p.1274).

${ }^{33}$ Overall Structural Organization of Conversation, (Sacks, 1992 [1970a], p. 157).
} 
Ainda segundo Robinson (2013, p.258), Sacks (1992 [1971a]) prefigurou a conceitualização da Organização Estrutural Global como fonte relativamente externa de coerência interacional, o que, além de abarcar a organização sequencial, transforma a construção e as oportunidades de participação na conversa. Essa coerência é um produto de múltiplas sequências de ação, que possuem uma Organização Estrutural Global (OEG).

É importante destacar o caráter êmico dos estudos de AC, que olham para OEG e observam como os interagentes mostram uma orientação para essa organização da interação em que os analistas tentam demonstrar como uma OGE reivindicada é relevante e, consequentemente, processual para os participantes (Schegloff, 1992C apud Robinson, 2013, p. 260).

Os/as analistas da conversa reconhecem que os aspectos das organizações estruturais gerais podem variar em termos da intersubjetividade dos/as participantes. Alguns aspectos podem ser familiares a todos/as os/as interagentes, enquanto outros podem estar familiarizados apenas com um (Jefferson e Lee, 1980; Lerner, 1998 apud Robinson, 2013, p. 260).

É válido ressaltar que as interações possuem pelo menos três fases, as quais têm estruturas sequenciais distintas, a saber: abertura, desenvolvimento e encerramento (Schegloff, 1972; Schegloff; Sacks, 1974). O desenvolvimento costuma variar muito e pode ter várias fases, a depender do tipo de interação.

De acordo com Robinson (2013), a abertura ou início da conversa é a atividade conversacional mais estudada. Seu estudo pode responder a questão de: “como iniciamos uma interação?”. Mas o autor ressalta que questões organizacionais irão depender da natureza da interação. Geralmente, as aberturas se encerram em posição âncora, que costuma ser ocupada com o primeiro tópico, normalmente, o motivo da interação, que se estende no desenvolvimento. Conforme ele destaca, as interações podem ocorrer em torno de um ou mais tópicos, bem como se estruturar a partir de um tópico específico. O fechamento, como o nome nos diz, se refere ao encerramento da interação.

É válido destacar que a OEG das interações pode ser estudada tanto na falaem-interação cotidiana, pedra fundamental da sociedade (Garcez, 2008), quanto em interações institucionais. O estudo de Drew e Heritage (1992) é referência para os 
analistas da conversa, no que diz respeito à diferenciação entre esses tipos de interações e à caracterização da conversa institucional.

Drew e Heritage (1992, p.4) ratificam que a fala institucional se dá, principalmente, pelo fato de que a identidade institucional ou profissional dos/as participantes se faz relevante, de alguma forma, para as atividades de trabalho nas quais estejam engajados. Os autores elencam aspectos que caracterizariam as interações intitucionais e destacam três de suas principais características:

1) Orientação dos participantes para o cumprimento de mandato institucional, isto é, uma meta institucional;

2) Restrições às contribuições aceitas;

3) Inferências de enquadres e procedimentos.

Estes aspectos são ratificados por Garcez (2002, p. 22), ao trazer a definição de fala ou conversa institucional desse estudo de Drew e Heritage (1992) e descrever essas características:

1 A interação institucional envolve uma orientação por parte de pelo menos um dos interagentes para alguma meta, tarefa ou identidade fulcral (ou conjunto delas), convencionalmente associada com a instituição em questão. Em suma, a conversa institucional é, normalmente, informada por orientações para metas, de caráter convencional relativamente restrito.

2 A interação institucional pode amiúde envolver limites especiais e particulares quanto àquilo que um ou ambos os participantes vão tratar como contribuições admissíveis ao que está sendo tratado na ordem do dia.

3 A interação institucional pode estar associada a arcabouços inferenciais e procedimentos que são peculiares a contextos institucionais específicos. (Garcez, 2002, p.57).

Em interações cotidianas, a OEG das conversas inclui atividades de abertura

e de fechamento da conversa, o desenvolvimento não possui uma ordem predeterminada, é coconstruído com os interagentes, conforme o contexto. Por sua vez, as interações institucionais costumam ter uma OEG específica, com fases ou ações que emergem em uma ordem particular, na qual os papéis sociais dos interagentes também emergem, no curso da interação.

Como nos mostra Drew e Heritage (1992), o espaço físico da interação não é determinante para dizer se uma conversa é institucional ou não, para tanto, torna-se indispensável a configuração da própria conversa e as identidades ressaltadas interacionalmente. Os autores usam o contexto médico para exemplificar essa ratificação: médico e paciente podem conversar informalmente e essas identidades se tornarem irrelevantes para o diagnóstico em uma consulta médica; enquanto, em 
outra situação, podem estar à beira da praia e conversarem sobre algum problema de saúde, discutindo sintomas de uma doença, o que seria característico de uma consulta médica.

Heritage (1997) propõe seis locais básicos para a investigação da institucionalidade na interação: 1) organização da tomada de turnos; 2) organização estrutural global da interação; 3) organização sequencial; 4) desenho do turno; 5) escolha lexical; 6) assimetria epistemológica e outros tipos de assimetria.

Como já foi dito aqui, durante a seção 3, Sacks; Schegloff e Jefferson (2003 [1974]) já previam que sistemas de troca de turnos que não sejam da conversa cotidiana teriam suas particularidades, a exemplo do tamanho e da ordenação dos turnos de fala, e o item 1 segue nessa linha. Heritage (1997) ratifica que, embora muitos tipos de interações institucionais possam fazer uso da organização de tomada de turnos da conversa cotidiana, alguns tipos envolvem transformações muito específicas e sistemáticas em procedimentos de tomada de turno. A organização da tomada de turnos envolve a seleção da ação que um turno de fala irá desempenhar (por exemplo, concordar, discordar ofertar algo, pedir, perguntar), e a seleção de como essa ação será performada (por exemplo, se será feita de forma direta ou indireta, se desenvolvida em um ou mais turnos de fala, se com accounts ou atenuadores, etc.). Em algumas interações institucionais, há um sistema de tomada de turnos muito específico e rígido quanto ao momento em que cada interagente pode tomar o turno; é o caso, por exemplo, das audiências em tribunais.

O item 2, a dimensão da Organização Estrutural Global, diferencia uma interação institucional de uma conversa cotidiana, pois, na primeira, há uma organização em fases específicas, que correspondem a tarefas institucionais, enquanto, na segunda, isso não ocorre. Desta forma, podemos dizer que as interações institucionais costumam ter algum tipo de script a ser seguido; ainda que esse não seja muito rígido, pelo menos uma das partes vai estar voltada para o cumprimento do mandato institucional, como já foi dito.

A organização sequencial diz respeito ao tipo de sequências que caracterizam a interação. Por exemplo, uma das sequências importantes que distingue as abordagens sociais, discutidas nesta tese, das conversas cotidianas é que, no primeiro caso, quando ocorrem ofertas, elas são feitas apenas por uma das partes, os/as voluntários/as, cabendo às pessoas atendidas aceitar ou recusar tais 
ofertas. Por sua vez, em conversas cotidianas, quando há ofertas, não há uma predeterminação de qual parte irá oferecê-las ou recebê-las.

Com o quarto nível, desenho do turno, o autor se refere aos recursos utilizados para formatar a ação, à seleção de elementos sintáticos, prosódicos, lexicais, entre outros, para formatar o que se pretende executar na ação almejada.

A escolha lexical torna possível invocar a institucionalidade, por meio da seleção das palavras ou termos empregados, o que pode marcar um conhecimento especializado e identidades institucionais (por exemplo, vocabulário técnico $\mathrm{x}$ leigo).

A última dimensão de análise mencionada por Heritage (1997), assimetria epistemológica e outros tipos de assimetria, está relacionada ao conhecimento de mundo que os interagentes possuem sobre os eventos sociais nos quais estão envolvidos como participantes ou como observadores, isto é a epistemologia social.

Nesta tese, direcionamos nossas análises às dimensões 2 e 3, a Organização Estrutural Global das abordagens sociais a pessoas em situação de rua, realizadas por voluntários/as de uma $\mathrm{ONG}$, e a organização sequencial dessas interações. 


\title{
Pressupostos metodológicos
}

Os pressupostos metodológicos que guiam este estudo, conforme já apontado, são os da Análise da Conversa (AC). Dessa forma, as interações foram registradas por meio de gravações de áudio e transcritas a partir de convenções de transcrição que marcam fenômenos da sequência conversacional e da fala, como: volume, entonação, duração das pausas (em centésimos de segundos), hesitações, reparos, falsos começos, interrupções, fala colada (quando alguém inicia o turno imediatamente após o outro terminar de falar), sobreposição, dentre outros.

As unidades de análise da $\mathrm{AC}$ são as ações sociais humanas pelo uso da linguagem em interação social. A AC tem como foco a articulação dos métodos dessas ações, como atribuir responsabilidade, explicar-se, iniciar reparo, etc., tudo isso segundo a perspectiva êmica, isto é, dos participantes, demonstrada uns aos outros na interação. Conforme ratificam Heritage e Atkinson (1984, p. 1):

\begin{abstract}
O objetivo central de pesquisas em Análise da Conversa é a descrição e a explicação das competências que os falantes comuns usam e de que se valem para participar de interações inteligíveis e socialmente organizadas. Em sua forma mais básica, esse objetivo é descrever os procedimentos por meio dos quais os participantes produzem seus próprios comportamentos e entendimentos e por meio dos quais lidam com o comportamento dos outros. Uma concepção básica é a proposta de Garfinkel (1967: 1) de que essas atividades - produzir comportamento e entendimento e lidar com isso - são realizadas como produtos de um conjunto de procedimentos passíveis de serem explicados ${ }^{34}$.
\end{abstract}

Além dos pressupostos metodológicos da $\mathrm{AC}$, fazemos uso de uma abordagem etnográfica. Então, para realizar uma melhor caracterização metodológica desta tese, apresentamos, nas subseções seguintes, o que concerne a essa abordagem e apresentamos, na sequência, informações específicas a respeito da pesquisa, como o universo em que ela se desenvolveu e a descrição dos dados.

\footnotetext{
34 Tradução reproduzida de Silva, Andrade e Ostermann (2009, p. 4). Texto original: “The central goal of conversation analytic research is the description and explication of the competences that ordinary speakers use and rely on in participating in intelligible, socially organized interaction. At its most basic, this objective is one of describing the procedures by which conversationalists produce their own behavior and understand and deal with the behavior of others. A basic assumption throughout is Garfinkel's (1967: 1) proposal that these activities - producing conduct and understanding and dealing with it -are accomplished as the accountable products of common sets of procedures."
} 


\section{1.}

\section{A abordagem (auto)etnográfica}

Já existe uma literatura que reconhece a contribuição da etnografia para pesquisas. A antropologia é um exemplo clássico. Mas também, no campo da linguagem, há estudiosos/as, como Garcez e Schulz (2015), que discutem a etnografia como escolha teórico-metodológica para a pesquisa em Linguística Aplicada, no Brasil. Nesse artigo, o autor e a autora defendem que a articulação da observação de base etnográfica com a AC pode potencializar o entendimento das ações de linguagem e permitir uma aproximação da perspectiva dos participantes a respeito do que ocorre em dada situação. Em suas palavras: "uma mirada estendida a outros momentos e cenários, evitando conclusões precipitadas e estabelecendo conexões com estruturas sociais menos facilmente observáveis" (Garcez e Schulz, 2015, p. 1).

A nossa proposta é articular a análise de dados de fala-em-interação com o trabalho de campo de natureza etnográfica, com o objetivo de potencializar o entendimento adequado de ações situadas. Segundo Severino (2007, p. 119), "a pesquisa etnográfica visa compreender, na sua cotidianidade, os processos do diaa-dia em suas diversas modalidades. Trata-se de um mergulho no microssocial, olhando com uma lente de aumento".

Vale dizer, ainda, que deve haver diferentes contribuições para uma investigação quando o/a pesquisador/a se socializa em um campo por um dado período e quando a pessoa é, de certo modo, membro desse campo. É o caso da pesquisa autoetnográfica, em que a pessoa que pesquisa "participa em termos mais ou menos iguais com outros participantes" (Coghlan e Brannick, 2005, p. 49).

Reed-Danahay (1997) traz uma revisão da literatura sobre a autoetnografia e defende que o conceito de autoetnografia, que guia o livro Auto/Ethnography: Rewriting the Self and the Social, reflete uma mudança de concepção do self e da sociedade depois do século XX, sintetizando tanto a etnografia quanto a autobiografia pós-modernas. Reed-Danahay (1997) afirma que o termo autoetnografia tem um duplo sentido, refletindo tanto a etnografia do próprio grupo - que é o caso desta tese - quanto a autobiografia escrita, que tem a etnografia como interesse. 
Ainda de acordo com Reed-Danahay (1997), há diferentes modos de tratar o conceito de autoetnografia em campos como os da antropologia, da crítica literária e da sociologia. Apesar das diferenças, uma das principais características da perspectiva autoetnográfica é que o autoetnógrafo exerce um papel que pode ser caracterizado como o de uma identidade dual: como pesquisador e como membro do grupo investigado. Para alguns autores, mas não para todos, essa condição de insider confere ao etnógrafo um status de autenticidade.

Dessa forma, no que concerne a este estudo, podemos ratificar que ele envolve também autoetnografia, na medida em que a autora é membro do grupo estudado, de voluntários/as que presta assistência às pessoas em situação de rua ou vulnerabilidade social estudado. Sua participação no grupo não é temporária, isto é, não se restringe ao tempo da pesquisa. Seu engajamento não tem prazo limitado; sua socialização é contínua, o que propicia certa familiaridade com o estilo de vida em questão neste estudo.

Apesar disso, apenas a escrita do capítulo cinco leva em conta uma escrita autobiográfica; os demais capítulos de análise não têm essa característica. Embora a perspectiva (auto)etnográfica tenha contribuído para um melhor entendimento dos dados, o foco é em uma perspectica êmica, característica dos trabalhos em Análise da Conversa, a qual não visa realizar análises psicológicas ou intencionais, mas, sim, a interpretação dos participantes da interação. Desta forma, sempre que na análise for feita referência à participante-pesquisadora, faremos uso da terceira pessoa do singular, uma vez que há o exercício de dois papéis que precisam ser, na medida do possível, separados: o de participante da pesquisa e o de pesquisadora. Assim, optou-se também por atribuir pseudônimo não somente aos/às outros/as participantes da pesquisa como também à própria autora.

Concordamos com Velho (1981) que nem sempre o que é familiar é conhecido. Por conseguinte, cumpre destacar que, como foi considerada a questão do autoconfronto com a identidade dual da autora desta tese - assim como o cuidado e respeito à perspectiva êmica, já mencionada - prevaleceu a preocupação com o que aconteceu no aqui e no agora das interações. Inclusive, é importante ressaltar que essa separação se tornou visível, à proporção que houve um autoconfronto com a própria prática, pois, enquanto voluntária da $\mathrm{ONG}$, a preocupação era com a 
abordagem social. Somente depois se tornava possível o olhar analítico de pesquisadora, que se surpreendeu com muito do que foi encontrado.

\section{2.}

\section{A pesquisa}

Esta pesquisa atende às normativas éticas e teve seu projeto aprovado pelo Comitê de Ética e Pesquisa (CEP), através da Pontifícia Universidade Católica do Rio de Janeiro (CI.VRAc. 59/2016), e, em seguida, pelo CEP selecionado pela Plataforma Brasil (CAAE: 65098416.1.0000.5289). Antes das participações, em geral, foram esclarecidos sobre os termos de participação, bem como elucidadas todas as dúvidas que surgiram. Nos casos de aceite, foi assinado o Termo de Consentimento Livre e Esclarecido ${ }^{35}$ (TCLE), em duas vias; uma ficou de posse da investigadora e a outra do/a participante. No único caso em que tivemos participante que não assina o próprio nome, houve a gravação de áudio da leitura do TCLE e da concordância do participante, por áudio.

De acordo com os preceitos da $\mathrm{AC}$, os fenômenos interacionais analisados foram eleitos conforme emergiram nos dados, isto é, data-driven.

\subsection{1.}

\section{$O$ universo da pesquisa}

A Turma da Sopa de Niterói atua no estado do Rio de Janeiro, município de Niterói. O referido município localiza-se às margens da Baía de Guanabara e de frente para a cidade do Rio de Janeiro. As cidades se ligam pela ponte Rio-Niterói, que tem quase 14 quilômetros de extensão. Dados do IBGE estimaram, em 2015, que a população de Niterói é de 496.696 habitantes.

A Turma da Sopa de Niterói teve início há mais de 10 anos. Embora não atuasse com esse nome, era formada por um grupo de Kardecistas que entregava alimentos, roupas e cobertores, nas ruas de Niterói, durante as noites de terça-feira, com a finalidade inicial de diminuir a fome e o frio dos moradores em situação de rua. No final do ano de 2012, esse grupo montou o que eles chamam de "rede do

\footnotetext{
${ }^{35}$ Os dois modelos de TCLE utilizados se encontram em anexo.
} 
bem”, com voluntários de várias religiões, sem vínculos partidários ou religiosos. Foi mantida a entrega de alimentos, como maneira de aproximação e de acompanhamento, além de ser realizado um trabalho mais social junto aos/às assistidos/as.

Mas o que é ser um voluntário? E de que forma essa atuação voluntária é formalizada na TSN? Conforme definição da Organização das Nações Unidas (ONU), "voluntário é o jovem, adulto ou idoso que, devido a seu interesse pessoal e seu espírito cívico, dedica parte do seu tempo, sem remuneração, a diversas formas de atividades de bem estar social ou outros campos". Assim como em todo trabalho voluntário formal, na TSN, cada voluntário/a assina um termo de adesão ao iniciar qualquer atividade voluntária, por meio do qual reconhece que seu trabalho não se dá mediante remuneração ou gratificação financeira de qualquer espécie e possui caráter exclusivamente voluntário, sem vínculo empregatício.

Atualmente, a TSN tem um projeto de trabalho com pessoas em situação de rua ou vulnerabilidade social, com estrutura e metodologia que têm como escopo promover a reinserção social de pessoas em situação de rua e apoiar famílias e indivíduos vulneráveis socialmente, na sua ascensão social. Desde janeiro de 2013, as pessoas que fundaram esse grupo começaram a chamar essa nossa formação de "Turma da Sopa de Niterói" (TSN). O ponto de encontro dos voluntários para preparação do alimento e para entrega na rua era, primeiramente, na Igreja Metodista do Ingá, numa cozinha emprestada pelo pastor, e no salão da Igreja do Colégio Salesiano Santa Rosa, numa cozinha também cedida pelos padres salesianos.

Durante os anos de 2013 e de 2014, as saídas à rua eram feitas às terças e às quintas-feiras; para cada dia havia o grupo de voluntários responsável pela realização do trabalho. O grupo correspondente a cada dia de trabalho se dividia, por sua vez, em dois grupos: um para a preparação dos alimentos (sopa, pães, frutas), no período da tarde, e outro para a entrega desses alimentos, cobertores, roupas, chinelos, materiais de higiene, leite em pó e de atendimentos de orientações e encaminhamentos sociais, conforme as necessidades, nas ruas de Niterói, à noite. Em 2014 e em 2015, eram prestados também outros tipos de assistência, como a retirada gratuita de documentação. Esse serviço era prestado com maior brevidade, pois uma Defensora Pública se tornou voluntária e passou a acompanhar/auxiliar a 
TSN. Todavia, atualmente, esse serviço não é oferecido diretamente pela ONG, que encaminha e orienta as pessoas sobre a retirada de documentos via Defensoria Pública ou Centro de Referência Especializado para População de Rua (CREPOP), de Niterói.

Em agosto de 2014, foi oficialmente fundada a Associação Turma da Sopa de Niterói. Nessa ocasião, como já era voluntária, me tornei uma das sóciafundadoras da Associação, constituída por meio de Assembleia que marcou o início da Associação TSN. Em abril de 2014, havíamos estruturado nossa sede própria e, a partir de então, nossa ida às ruas passou a ocorrer às segundas-feiras. Há também o encontro aos sábados, para recolher doações de frutas e de legumes, em um Hortifruti, e, eventualmente, realizar encontros para organizar eventos públicos que tenham o intuito de arrecadar fundos, para organizar algo que esteja pendente e não possa ser feito na segunda-feira. Oficialmente, há quatro pontos de entrega: três deles são em locais em que as pessoas assistidas dormem, e um deles é em um local aonde elas vão para nos encontrar, bem como para encontrar outras Organizações que fazem algum tipo de doação. Quando o alimento excede ao necessário, em determinada noite, estende-se o percurso a um ou mais pontos.

A Equipe de Abordagem Social é responsável pela escuta contínua enquanto há uma equipe responsável pela entrega dos alimentos. É por meio das conversas com os assistidos, dessa escuta e das entregas e encontros de todas as segundasfeiras, que estabelecemos um vínculo de confiança com os assistidos. O alimento serve de instrumento para chegarmos até eles, pois é uma das necessidades biológicas do ser humano, e a assiduidade na entrega, durante todas as segundasfeiras, cria um laço de credibilidade entre os assistidos e a TSN. Essa escuta, bem como as sondagens são muito importantes, porque, por meio delas, criamos vínculos e conhecemos melhor cada assistido/a. Eles/as demonstram bastante alegria quando os/as chamamos pelo seu nome próprio, pois se sentem reconhecidos/as, lembrados/as e individualizados/as. Todo o processo também consiste num resgate da esperança e da autoestima do/a assistido/a.

A reintegração à vida social acaba por ser feita em um espectro que varia da visibilidade por meio da conversa semanal - em que as pessoas atendidas podem desabafar e se sentir visíveis e estimulados/as a algum tipo de mudança - até às ofertas de ajuda mais concretas, como: orientações para a retirada de segunda via 
de documentos; oferta de panfletos ou currículos que facilitem o retorno ao mercado de trabalho; instruções ou passagens para entrevistas de emprego; oferta de atendimento psicológico, de encaminhamento a abrigo e/ou de aulas de reforço.

Algumas dessas ofertas são respostas a pedidos; outras são oferecidas a partir da suposição de necessidade, derivada da escuta/sondagem. Uma vez que alguém está na rua, supõe-se que a pessoa possa querer alguma ajuda que a permita sair daquela condição. É com essa disposição que se inicia a conversa, por meio da qual é comum o surgimento de condução propositiva, que vai desde sondagens até oferecimentos explícitos e arranjos para a execução de alguma proposta de reinserção e/ou negociações que demonstrem sua pertinência.

É interessante dizer que não há um script por escrito que oriente como começar a abordagem social, nem um formulário específico a ser preenchido com as informações de quem é atendido, diferentemente do que costuma acontecer em setores do atendimento social. É possível, todavia, dizer que existem scripts implícitos, uma vez que a equipe tem um mandato institucional a ser cumprido. Além disso, os/as membros/as da equipe de abordagem da TSN fazem anotações, eles/elas procuram anotar o nome das pessoas que atendem e detalhes do atendimento, como dia e informações que julgarem importantes, porém, é diferente do uso de formulários prontos, que são usados somente para casos específicos, como preparação de currículo, por exemplo.

Atualmente, temos o Programa Acreditando no Ser humano (CrêSer), que tem como função apoiar o crescimento e o fortalecimento social da família e do indivíduo em situação de vulnerabilidade social. Desse Programa, fazem parte os projetos de roda de leitura e dança (jazz), que ocorrem aos sábados, na sede da turma, além do reforço escolar para crianças e adolescentes, que acontece durante a semana; bem como cursos de artesanato e curso iniciante em inglês, para as responsáveis que levam as crianças à roda de leitura e ao jazz. As famílias cadastradas no Programa que tenham filhos ou netos na faixa etária de 6 meses a 7 anos de idade recebem 1 pacote de leite em pó, por semana. Além disso, conforme as doações, são entregues cestas básicas, roupas, calçados, itens de higiene, etc.

O cadastro para participação nas atividades citadas é efetuado por meio de apresentação da certidão de nascimento da criança, do documento de identidade do responsável que comprove o vínculo com a criança, do cartão de vacina da mesma, 
bem como do comprovante de matrícula escolar na rede pública de ensino. $\mathrm{O}$ Programa faz também a entrega de enxoval a grávidas que se encontrem na mesma situação vulnerável. O enxoval é entregue depois da apresentação de comprovante de acompanhamento médico por meio do pré-natal; essa foi uma maneira de estimular essas mães a terem o devido cuidado com a própria saúde e com a saúde do bebê. Também é estimulado às mulheres acompanhadas que tenham algum planejamento familiar, com orientações no sentido de evitar gravidez indesejada.

Em resumo, a TSN é composta por um grupo de voluntários/as, que objetiva - por meio da entrega de alimento, do carinho, da atenção e da conversa constante - criar um ambiente de escuta para identificar anseios de mudança do/a morador/a em situação de rua ou vulnerabilidade social, estabelecendo vínculos de confiança e de respeito junto aos assistidos, para que se ofereçam, ao mesmo tempo, oportunidades e possibilidades para o processo de reintegração à sociedade. No momento, a Associação não recebe nenhuma verba pública; ela é mantida somente por meio de doações de pessoas físicas ou jurídicas que acreditam e apoiam os projetos da ONG.

\subsection{2. Os participantes}

Os/as participantes desta pesquisa são pessoas em situação de rua ou de vulnerabilidade social e os/as voluntários/as da TSN da equipe de abordagem social, bem como alguns outros que acabaram atuando na gravação de alguma interação. $\mathrm{O}$ fato de a pesquisadora ser parte do grupo estudado facilitou os aceites aos convites para participação da pesquisa; dentre as pessoas convidadas, todos/as os/as voluntários/as aceitaram e, dentre as pessoas assistidas, apenas duas não quiseram participar e preferiram não ter seus atendimentos gravados. Totalizam-se, assim, 23 assistidos/as (14 mulheres e 9 homens) e 18 voluntários/as (13 mulheres e 5 homens), com formações diversas, dentre elas havia: assistente social, professora, administrador, psicóloga, advogado/a, médica, enfermeira, farmacêutico e funcionário/a público/a, tratando-se de uma equipe bem diversificada, sendo que as suas formações profissionais não foram o motivo pelo qual essas pessoas foram convidadas a fazer parte da equipe. 
No início, o convite foi feito a todas as pessoas que se mostraram disponíveis a aceitar, mas algumas delas não chegaram a ter interações gravadas, pois várias interações ocorriam ao mesmo tempo, em locais diferentes, na rua, sendo que havia apenas um gravador usado para registros da pesquisa. Vale ressaltar que tanto os nomes dos/as participantes quanto os nomes citados por eles/as foram trocados por pseudônimos ${ }^{36}$, para garantir o anonimato. Também houve um apagamento das informações pessoais que pudessem servir de identificação dos/as envolvidos/as, ao fazer as transcrições.

\subsection{3. \\ Os dados}

Para a AC, é importante que os dados analisados sejam de origem naturalística, ou seja, de ocorrência natural, interações reais e não simuladas, que ocorram independente do desenvolvimento da pesquisa. Este é o caso do nosso corpus. As abordagens sociais analisadas aqui não foram geradas para que fossem analisadas. Independentemente da pesquisa, elas iriam ocorrer.

A geração de dados contou com gravações em áudio ${ }^{37}$ de interações reais de atendimento aos/às assistidos/as, que contabilizam quase 14 horas de gravação. Antes dos objetivos bem delimitados, algumas gravações tiveram uma primeira transcrição completa, para podermos visualizar melhor os fenômenos, mas, depois dos objetivos bem delimitados, houve uma escuta exaustiva dos dados, para identificar as gravações e as partes que seriam analisadas nesse estudo e serem transcritas ou terem sua transcrição refinada, observando-se as convenções de transcrição a serem utilizadas.

O foco dessa escuta foi em interações completas, para identificar partes da interação que se repetiam e podermos escrever sobre a organização global das

\footnotetext{
${ }^{36}$ Garcez (2002) mostra que a prática de atribuir nomes próprios (reais ou pseudônimos) aos participantes da pesquisa é usada academicamente para a identificação dos falantes nos textos (transcrição e análise) em AC, e defende essa opção de identificação dos participantes da pesquisa. ${ }^{37}$ Também gravamos duas reuniões entre a equipe de atendimento, com sessões de análise conjunta de dados, o que possibilitou uma reflexão sobre a prática do grupo e trouxe ricas reflexões, semelhantes às que chegamos enquanto analistas da conversa, mas que podem ser aceitas mais facilmente por se tratar de reflexões dos próprios membros e podem ajudar bastante a aperfeiçoar as suas práticas. Porém, para a tese, não chegamos a analisar esses dados.
} 
interações. Além disso, buscamos identificar as microações que ocorriam em cada etapa da interação e também de ofertas e seus desenvolvimentos, já que essa ação se mostrou uma das principais da abordagem.

Os arquivos de áudio e de transcrição foram salvos com a seguinte codificação para facilitar o manuseio: nome do assistido, em caixa alta, seguido dos nomes dos/as voluntários/as participantes da interação, em caixa baixa, do dia, do número da gravação, seguido do ano. Cada informação foi separada por underline. Os dias, faz-se relevante destacar, foram registrados por dia de gravação e não por data, os anos seguiram a mesma lógica, de forma que os dados gerados em 2016 foram nomeados com ano 1, 2017 como ano 2 e assim sucessivamente. Exemplo da codificação: ALICE_merida_dia19_grav1_ano1, em que as interagentes são Alice, assistida, e Merida, voluntária; o dado foi gravado no décimo nono dia de geração de dados; sendo a primeira gravação da noite, ocorrida no ano de 2016. Além disso, para facilitar a localização de fenômenos interacionais, bem como das próprias interações usadas e a soma dos tempos de gravação, fizemos uma planilha de Excel com as seguintes colunas: dia, número, data, local de atendimento, duração em segundos, duração em minutos e segundos, participantes principais, conteúdo do atendimento e observações.

Ademais, contamos com notas de campo feitas pela pesquisadora/voluntária, tomadas entre os anos de 2016 e $2019^{38}$. Essas interações ocorreram nos locais de entrega e de atendimentos da TSN, isto é, nas ruas ${ }^{39}$ de Niterói. Dada a particularidade do contexto da pesquisa, não optamos por fazer gravações de vídeo, pois, embora saibamos que uma análise multimodal enriquece bastante a investigação e esteja sendo cada vez mais utilizada, esse tipo de registro poderia dificultar a própria tarefa de aproximação da equipe de atendimento à população em estudo. Nesse contexto, a gravação em áudio e as notas de campo se mostraram eficazes para os propósitos desta pesquisa.

\footnotetext{
${ }^{38}$ Durante esse período, apenas de agosto de 2017 a março de 2018, a pesquisadora não estava em campo, pois participava do Programa de Doutorado Sanduíche no Exterior (PDSE), em Lisboa, onde teve a oportunidade de conhecer a realidade da população em situação de rua de lá. Mas ao retornar, voltou a campo.

${ }^{39}$ Apenas um dos atendimentos gravados ocorreu na sede da ONG. Vale ressaltar, ademais, que também foram geradas entrevistas com assistidas mulheres, pois temos pretensões de usar esses dados para trabalhos futuros sobre o que é viver nas ruas, enquanto mulher, bem como com os/as voluntários/as integrantes da equipe de abordagem, embora esses dados tenham acabado não fazendo parte desta tese.
} 
A respeito dessa abordagem, Del Corona (2011, p. 58) defende que:

O material obtido através das gravações é analisado, juntamente com outros recursos, como notas de campo, entrevistas e documentação relativa ao evento. $\mathrm{O}$ fato de o pesquisador ter a oportunidade de rever o material gravado com os participantes e obter suas percepções do que fora coconstruído naquela interação diminui as chances de os achados serem reduzidos a análises psicológicas e/ou sociológicas (Del Corona, 2011, p. 58).

As gravações foram transcritas conforme as notações da AC, com base nas convenções propostas por Jefferson (1974), usando a fonte courrier new, amplamente utilizada em transcrições de AC, porque todos os caracteres ocupam a mesma quantidade de espaço, o que torna mais fácil o alinhamento das falas sobrepostas, registradas em linhas diferentes. Como ratifica Gago (2002, p. 95), ao trazer reflexões acerca da transcrição em AC, "A literatura reporta a existência de dois sistemas, que podem ser utilizados complementarmente ou de forma excludente: a escrita padrão e a escrita modificada".

Cientes da necessidade de tomar decisões na hora de transcrever (Gago, 2002), optamos por fazer uso do sistema misto de ortografia padrão da norma culta e grafia modificada. Isso resultou nas seguintes escolhas: uso de alguns registros da oralidade como "pra" ao invés de "para", bem como variantes das formas de tratamento, por exemplo, "cê" equivalente a "você", mas não marcação do apagamento do "r" final dos verbos no infinitivo, nem da falta de concordâncias verbal ou nominal. Essa escolha não se deu de forma aleatória; ela foi fruto de vasta reflexão a respeito do fato de as pessoas em situação de rua ou vulnerabilidade social já serem bastante estigmatizadas e termos o receio de contribuir para a manutenção de tais estigmas. É sabido que alguns casos - como o apagamento do "r" - são comuns em português brasileiro, nas diversas classes sociais (Bagno, 2011) e estaria presente também na fala dos/as voluntários/as. Mas, quando ocorrem na fala de assistidos/as, esses fenômenos podem contribuir para a construção de uma imagem negativa dessas pessoas. Enquanto linguistas que somos e como pesquisadoras que querem contribuir para diminuir/acabar com o preconceito linguístico (Bagno, 1999), somos tentadas a optar apenas pela grafia modificada, na tentativa de normalizar esses usos da oralidade. Em contrapartida, por conta da preocupação social em evitar estereótipos, tomamos essa decisão, pois, como defende Chimamanda (2009), “o problema com os estereótipos não é que eles não são verdade, mas é que eles são incompletos. Eles fazem uma história se tornar 
a única história" ${ }^{40}$. Afinal, como aponta Ribeiro (1994), estudos como o de Preston (1985 apud Ribeiro, 1994) abordam a repercussão da grafia modificada no leitor e mostram que profissionais que não são linguistas (de áreas distintas, como médicos, advogados e empresários) tendem a construir uma imagem negativa das pessoas que têm sua fala representada pela escrita modificada, tendendo a rebaixar a classe social ou o nível de escolaridade dessas pessoas. Gago (2002) chegou a resultados semelhantes aos de Preston.

Nessa linha, a posição assumida aqui é a de que as tomadas de decisão não estão livres das crenças e das impressões de mundo da autora, o que nos afasta da tentativa de apresentação de uma verdade absoluta e objetiva do fenômeno estudado. Alinhamo-nos, ainda, à perspectiva de que o produto da pesquisa é sempre parcial, incompleto e provisório (Moerman, 1992, p. 26) e que a pesquisa é uma leitura social, sempre aberta a releituras, inclusive pelos próprios autores e leitores. Como lembra Silva et a. (2009, p. 6), ao terem contato com análises,

os pesquisadores têm a oportunidade de 'voltar aos dados' sobre os quais uma determinada asserção foi feita e chegar a suas próprias conclusões (que podem coincidir ou não com a análise previamente feita), sem precisar tomar a análise apresentada como verdade absoluta e incontestável (SILVA et al., 2009, p. 6).

Quando é possível disponibilizar, publicamente, as próprias gravações é melhor, mas, para isso, seria preciso consentimento prévio dos participantes da pesquisa e, infelizmente, esse tipo de consentimento não chegou a ser solicitado.

\footnotetext{
${ }^{40}$ Tradução livre de: "the problem with stereotypes is not that they are untrue, but that they are incomplete. They make one story become the only story." Disponível em: https://www.ted.com/talks/chimamanda adichie the danger_of_a single story .
} 


\section{Notas de campo sobre o trabalho da equipe de abordagem social: o complexo processo de intervenção social}

\footnotetext{
"Uma das maiores provações que passei na rua foi comer comida do lixo. Nas primeiras vezes, eu esperava todo mundo sair da rua para ir catar no lixo, depois eu passei a pegar à vontade, na frente de todo mundo".
}

A fala acima é um desabafo do Augusto, assistido que esteve em situação de rua. Ele se categoriza como uma pessoa muito tímida, que sofreu bastante assim que foi levado a morar nas ruas, pois não gostava de pedir nada a ninguém. No início, ele disse que não conhecia os grupos de assistência social da prefeitura ou ONG's e instituições religiosas que pudessem ajudá-lo, de alguma forma. No entanto, depois de um tempo, ele conheceu várias Organizações, dentre elas a TSN e, aos poucos, surgiram oportunidades que possibilitaram a sua saída da rua.

O trabalho de intervenção social realizado pela TSN é inicialmente construído pelas ações da Equipe de Atendimento Social, daqui para frente EAS. Trata-se de uma prática em que a linguagem assume importância central, uma vez que todas as ações se realizam por meio da fala-em-interação dos/as voluntários/as com as pessoas em situação de rua ou vulnerabilidade social. O objetivo deste capítulo é apresentar o trabalho da EAS, tendo como base as notas de campo realizadas durante o período de pesquisa.

Para um entendimento mais aprofundado da dimensão e da complexidade da dinâmica e do universo micro das interações das abordagens sociais da TSN, é importante pensar o macro. E, por isso, este capítulo tem como escopo descrever as etapas que constituem as intervenções sociais, que são orientadas para a reinserção social.

$\mathrm{Na}$ seção 5.1, apresentamos as etapas que constituem o processo de intervenção social. Na 5.2, por sua vez, relatamos dois casos que ilustram diferentes tentativas do processo de intervenção social.

\section{1.}

\section{As fases do trabalho da intervenção social}


O trabalho de intervenção social é desenvolvido em três etapas: 1) aproximação; 2) escuta e sondagem; e 3) condução propositiva ${ }^{41}$, que envolve diferentes tipos de oferta de ajuda. Neste capítulo, estamos tratando da intervenção em sentido amplo, com uma perspectiva longitudinal, não apenas pensando em atendimentos individuais, ocorridos em um mesmo dia.

Tais etapas foram apreendidas ao longo desta pesquisa: por mais que a EAS siga, ainda que intuitivamente, esse processo, a ONG ainda não desenvolveu uma capacitação que preveja cada uma dessas etapas, que oriente a equipe em sua condução. Porém, as notas de campo, juntamente com as gravações, suas transcrições e análises, nos forneceu a identificação das fases desse processo, que representam um contínuo. Mais que isso, há momentos em que essas fases são uma espécie de engrenagem importante para a concretização da reinserção social dos/as assistidos/as, visto que elas podem se entrelaçar, de forma que haja uma concomitância, um hibridismo entre as fases. A imagem que segue ilustra isso. Note que as etapas estão um pouco separadas, mas, ao se aproximar duas delas ou mais, elas podem "girar"/acontecer concomitantemente.

Imagem 1 - Etapas do processo da intervenção social em uma engrenagem

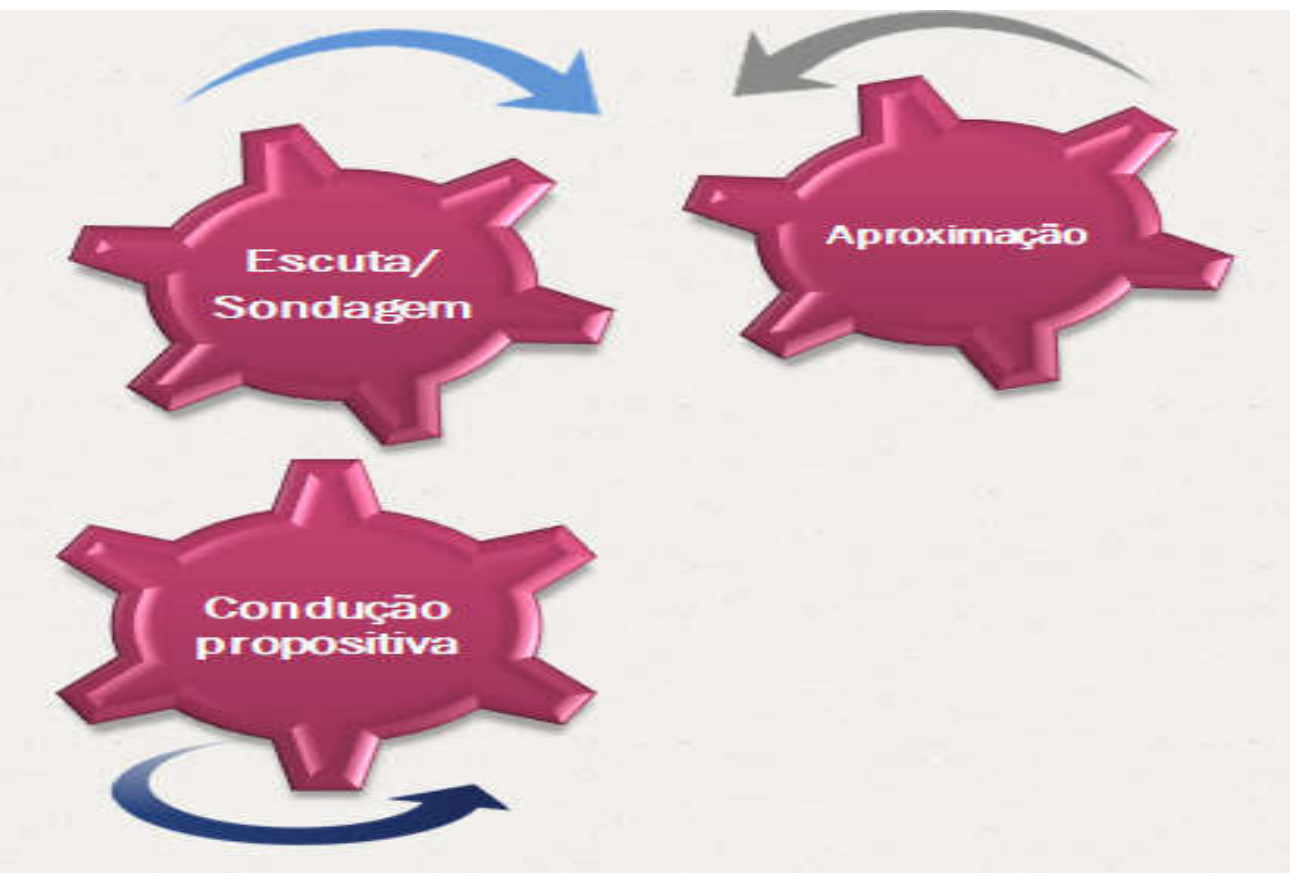

Fonte: Elaborado pela autora.

\footnotetext{
${ }^{41}$ Este termo foi uma contribuição do colega Victor Braga, em uma das sessões de análise conjunta de dados realizadas no seio do GEACC, em Lisboa.
} 
Em síntese, a aproximação consiste tanto na aproximação física quanto na construção e manutenção do vínculo entre os/as voluntários/as e assistidos/as. É por meio dessa etapa que se consegue conquistar a confiança das pessoas atendidas, para que elas se abram e compartilhem seus problemas. Esse compartilhamento ocorre na fase da escuta e sondagem, em que os/as voluntários passam a conhecer melhor essas pessoas e suas demandas, por meio de uma escuta ativa e de sondagens, fase muito importante, pois pode, inclusive, criar serviços específicos, conforme a necessidade e dificuldade compartilhadas pelas pessoas atendidas. Por sua vez, a condução propositiva é a etapa em que ocorrem as ofertas de ajuda, que podem ser de tipos variados, a depender da sondagem/escuta, por exemplo: a falta de documentos leva ao oferecimento de orientações sobre como retirar segunda via; questões emocionais/psicológicas podem levar os/as voluntários/as a oferecerem atendimento psicológico; vontade de sair da rua pode gerar ofertas de ida para abrigos ou orientações a respeito, bem como ofertas de retorno à terra natal, ou de cursos geradores de renda, cartões, panfletos ou currículos que possam contribuir para o retorno ao mercado de trabalho e a possível saída da rua, etc.. Depois de essas três fases serem cumpridas com êxito, caso a pessoa atendida queira, tenta-se criar um plano de ação junto com ela, em que há uma retroalimentação dessas fases.

Assim, essas três etapas se complementam e são fundamentais para o processo de intervenção social. É importante mencionar, porém, que essa divisão não é rígida, já que a aproximação pode ser reforçada em todas as fases, por meio da demonstração de interesse pelo/a outro/a. Apesar disso, essa divisão, para fins didáticos, torna possível entender melhor a intervenção social.

\section{2.}

\section{Os diferentes tempos do processo de reinserção social}

Nesta seção, relatamos dois casos que mostram o fluxo das etapas do processo. Na seção 5.2.1., apresentamos o caso de Dona Joana, cuja etapa de aproximação precisou ser constantemente alimentada, e a etapa de sondagem e escuta, embora alcançada, não levou ainda à concretização de nenhuma condução propositiva tentada. Na seção 5.2.2., apresentamos o caso de Acácia que ilustra o fluxo de todas as etapas do processo (seção 5.1.) e como se deu a sua saída da rua. 


\subsection{1.}

\section{O caso de Dona Joana}

Conhecemos Dona Joana em 2016. Ela está na rua há alguns ${ }^{42}$ anos, e, já nas primeiras conversas, nos disse ter passado por abrigo, mas não desejar voltar. Sondamos se ela teria interesse em um novo abrigo, em outro local, e oferecemos atendimento psicológico e ajuda para regularizar seus documentos e dar entrada no Benefício da Prestação Continuada (BPC), da Lei Orgânica da Assistência Social (LOAS). Tudo isso ao longo de diferentes encontros, sempre que aparecia uma oportunidade. No entanto, Dona Joana afirmava repetidas vezes não precisar de nada do que era oferecido.

Diante da recusa de todas as tentativas, as voluntárias apenas se colocaram à sua disposição, sem emitir avaliações negativas, mas explicando que, se ela precisasse de algo, só precisaria dizer. A assistida agradeceu, mas permaneceu sem dizer muito. Mesmo assim, todas as segundas-feiras em que Joana estava em algum dos nossos pontos de entrega, ${ }^{43}$ íamos até ela e verificávamos se já tinha recebido o alimento e/ou o produto de higiene, de que estivesse precisando. Nas primeiras semanas, a assistida se manteve desconfiada, pensativa e quase não falou. Com o passar do tempo, vez ou outra, quando o nosso veículo de transporte chegava, ela saía de seu local e ia ao nosso encontro, desejando nos cumprimentar. Quando ela não vinha, éramos nós que íamos até ela, invariavelmente recebidas com um abraço. Costumamos tentar estimular que as pessoas assistidas passem a ter a iniciativa de ir ao nosso encontro quando chegamos aos locais pretendidos, ao invés de esperar no local exato em que elas dormem, como uma pequena forma de aumentar a autonomia e a mobilização dessas pessoas.

É fato que a aproximação foi atingida com sucesso, pois houve a construção da relação de confiança. A evolução da relação foi notável: começamos a conhecer um pouco mais sobre ela, a saber suas preferências, e até descobrimos que estudava inglês sozinha, por exemplo. Enfim, a cada segunda, uma descoberta e um

\footnotetext{
42 Tal imprecisão se dá por conta de ela nunca ter dito ao certo a quantidade de anos em que vive nas ruas.

${ }^{43}$ Não só Dona Joana mas a maioria das pessoas que vivem em situação de rua migram de um local a outro, pelos mais diversos motivos. Por isso, muitas vezes, elas se estabelecem em pontos distintos. Essa é uma das vantagens de não ficarmos em um único local, ao aguardo dos assistidos, mas nos deslocando até eles.
} 
fortalecimento do vínculo. Mas foi só em abril de 2018, mais ou menos dois anos depois de conhecê-la, que ela se abriu de maneira mais profunda e contou "todas" as suas verdades sobre si. Tive a sorte de ser uma das voluntárias presentes: éramos Rejane e eu, mas acredito que poderia ter sido qualquer pessoa da EAS que foi se familiarizando com ela.

Naquele dia, Dona Joana falou por quase quarenta minutos, no que Rejane, que é psicóloga, chamou de "uma verdadeira catarse". Dona Joana chorava ao nos contar fatos de sua história de vida. Logo no início, quando fizemos alguma pergunta, ela disse que não queria falar sobre o assunto, porque a deixaria triste; então, propusemos mudar de assunto e iniciamos outro tópico. Entretanto, ela precisava falar e retornou ao suposto assunto, e não parava de contar detalhes e de nos pedir desculpas por não aceitar ajuda, isto é, ofertas de abrigo, documentos ou de ir ao médico. Dissemos que entendíamos, que era direito dela. Contou-nos que não queria reaver seus documentos, nem tratar de sua saúde, porque Deus tinha aparecido para ela e dito que a buscaria em algum momento, para que pudesse nascer novamente - só que, então, em uma família que a merecesse, que the proporcionasse o amor e os cuidados que uma criança merece, ao contrário do que tinha acontecido em suas outras vidas. Dona Joana dizia que não era justo ter passado por todas as coisas ruins que nos descrevera, nem pelas várias famílias da qual fizera parte. Naquele dia, atrasamos um pouco nossa saída: quando algum/a assistido/a está disposto a se abrir e a falar mais, não saímos do ponto sem que haja oportunidade de fechamento da conversa. O contrário poderia ser brusco e desagradável, além de prejudicar a oportunidade da sondagem, de conhecer melhor as pessoas que atendemos.

A narração de Dona Joana parecia um delírio. Muitas informações (algumas das quais omitidas aqui, de modo deliberado) desconexas e aparentemente fantasiosas ou surreais eram - e isso estava muito claro - a sua verdade, que, enfim, ela sentira necessidade de compartilhar conosco. Tratava-se de mais um caso de manifestação de problemas mentais, em que não há muito o que possamos fazer. Ainda assim, oferecemos levá-la a um psiquiatra, visto que ela tem muitas dores de cabeça, mas ela recusou. Recusa justificável, uma vez que Dona Joana dizia ter medo de cuidar-se e de viver, então, estava, há muitos anos, atrasando a tão sonhada vida merecida. Restaram-nos o contato semanal mantido e a disposição sempre 
reafirmada de encaminhá-la a uma psicóloga e/ou psiquiatra, para que pudesse se cuidar, caso fosse de sua vontade. Na semana seguinte, ela nos procurou e pediu desculpas por todo o "desabafo" (palavra dela). Agimos com naturalidade e mostramo-nos solícitas, na esperança de que, um dia, Dona Joana deseje ser atendida por algum/a especialista, bem como de que nosso contato constante amenize um pouco a dor de seus sofrimentos sociais. Nosso reencontro acontece todas as segundas-feiras. Então, podemos dizer que, no que se refere à aproximação e às sondagens, o sucesso foi atingindo, e, embora, nenhuma condução propositiva de reinserção social tenha sido aceita, resta à EAS acolhê-la, como pessoa que traz o sentimento de não ter sido acolhida nem pela própria família.

\subsection{2.}

\section{O caso de Acácia}

Acácia, diferentemente de Dona Joana, teve conosco um processo de aproximação mais rápido. Nós a conhecemos em fevereiro de 2017, quando estava na rua apenas há alguns meses. Ela logo nos disse que sentia muita vontade de sair da rua e de voltar a estudar, para tentar ingressar na Universidade, pois já tinha o Ensino Médio. Aparentava não ter vícios e afirmava ter muita vontade de mudar. Percebemos sem demora que poderia ser uma assistida encaminhada ao abrigo parceiro, que fica na Região Metropolitana do Rio de Janeiro, próximo a Niterói. Sondamos seu interesse, caso houvesse vaga, e a EAS seguiu fazendo sondagens, buscando obter o máximo de informações sobre ela. No segundo encontro, Acácia nos contou que tinha voltado a estudar: ela se inscrevera no pré-vestibular comunitário da Universidade Federal Fluminense, aos sábados. Ainda nesse encontro, nós lhe oferecemos atendimento psicológico, que ela aceitou, comprometendo-se a ir à sede para a primeira sessão. Lá, haveria mais tempo para uma boa conversa, que nos permitisse conhecê-la melhor e acertar os detalhes de sua possível ida ao abrigo.

Depois de cerca de três semanas, combinamos de levá-la ao abrigo. No dia marcado, Helena e eu, voluntárias da EAS, e Roberto, voluntário que faz parte do Apoio TSN, buscamos Acácia de carro, acertamos que ela continuaria indo ao atendimento psicológico e às aulas do pré-vestibular, em Niterói, e que a TSN 
arcaria com o custo das passagens, uma vez que sua única fonte de renda era o programa Bolsa Família. Ao chegarmos ao abrigo, Helena e eu fomos ao quarto mostrar-lhe o espaço e ajudá-la a ambientar-se ao novo local. Ainda um pouco tensa, ela nos disse que tinha algo a revelar: seu nome não era Acácia; ela se chamava Mariana. Pediu-nos desculpas por mentir sobre seu nome e mostrou-nos sua carteira de identidade. Explicou-nos que uma das maneiras de se defender na rua era ter um nome diferente do verdadeiro, principalmente no seu caso, porque Mariana temia que seu ex-companheiro a encontrasse. O medo advinha de sua vivência de relacionamento abusivo com ele, sobre o qual ela já havia nos contado.

A descoberta tardia de seu nome real deixa ver mais uma faceta da complexidade das relações de que tratamos aqui, bem como da importância dada ao seu nome, à sua identidade social, que veio à tona, apenas, quando Mariana estava fora das ruas e poderia sentir, novamente, que fazia parte da sociedade com seu verdadeiro nome. Talvez o fato de que teria mesmo que mostrar seus documentos, no momento de formalizar sua entrada no abrigo, foi encorajador para a revelação, pois seria preciso assinar um termo em que constassem as informações da abrigada. Explicamos que compreendíamos sua situação, mas lhe pedimos que fosse muito sincera conosco a partir daquele momento, pois uma relação de confiança seria imprescindível para o recebimento de qualquer ajuda que a TSN pudesse lhe dar. Nossa interação seria de cooperação, troca e proximidade: continuaríamos, juntamente com ela, a fazer um plano de ação para que ela pudesse, no futuro, não precisar estar mais no abrigo e conseguisse meios de se sustentar. Desde o início do planejamento de ida ao abrigo, conversamos que o objetivo era justamente esse.

Nas primeiras semanas no abrigo, Mariana estudava lá e se deslocava para as aulas do pré-vestibular, aos sábados, em Niterói: sempre pontual, caso chovesse ou fizesse sol, e demonstrando-se muito dedicada. A responsável pelo abrigo também compartilhava conosco informações sobre seu comportamento enquanto abrigada. Depois de uma das sessões de atendimento psicológico, conversamos com ela sobre o plano de ação de sua reinserção social. Como ficara evidente seu empenho e interesse em relação aos estudos, propusemos que ela passasse o ano de 2017 dedicando-se exclusivamente ao aprendizado, desde que continuasse a fazer o que lhe cabia, esforçando-se. Além do acompanhamento psicológico, contaria 
com aulas particulares de biologia, química, matemática, redação, literatura e espanhol, ministradas por professores/as voluntários/as, durante a semana. Aos sábados, continuaria indo às aulas do pré-vestibular. Mariana concordou com tudo, de imediato, e mostrou-se bastante empolgada com a oportunidade.

Apesar das dificuldades conhecidas e vividas, sua aprovação em uma universidade pública parecia uma ótima opção: se passasse para uma universidade federal que oferecesse o mínimo de assistência social, ela poderia morar em residência universitária, receber auxílios sociais e ter sua chance de recomeço, a partir de seu próprio sonho. Caso não passasse, no ano seguinte, poderia começar a trabalhar de dia e a estudar de noite, prosseguindo com as tentativas e perseguindo seu objetivo maior. Foi combinado que ela poderia ficar sem trabalhar apenas até a prova do Exame Nacional do Ensino Médio (ENEM). Passada essa fase, Mariana e a TSN buscariam um emprego que lhe garantisse a sua independência. Nesse ínterim, a assistida foi inserida também no programa de acompanhamento oftalmológico e odontológico, desenvolvido com profissionais parceiros/as da TSN, e ganhou os óculos de uma ótica também parceira.

O ano de 2017 foi de contato intenso com Mariana e de muito esforço e dedicação de todos - tanto da assistida quanto de muitos/as voluntários/as e parceiros/as que lhe atenderam. As dificuldades apareceram, mas foram superadas, uma a uma. Após o ENEM, realizado em novembro de 2017, teve início a busca do emprego, pois o resultado da prova só sairia em janeiro. Apesar das tentativas, currículos entregues por ela, pessoalmente, e cadastrados em sites, pela TSN, nada aparecia.

Em janeiro de 2018, saíram as notas do ENEM, e, em seguida, a data de inscrição no Sistema de Seleção Unificada - SISU. Começou-se a estudar as possibilidades de aprovação nos cursos que ela desejava, levando-se em consideração as universidades que oferecessem residência universitária. Sua nota possibilitaria a aprovação no curso mais desejado - turismo -, em uma universidade em outro estado do Brasil ${ }^{44}$, que proporcionava as condições mínimas necessárias de assistência social.

\footnotetext{
${ }^{44} \mathrm{~A}$ omissão do nome do estado faz parte dos cuidados de proteção à identidade da assistida.
} 
A diretoria da TSN estava disposta a investir na ida de Mariana para lá, se ela assim o desejasse. A partir de então, iniciou-se uma fase de muito diálogo: era preciso saber de seu real interesse de mudar de estado, para perseguir seu objetivo e fazer o curso desejado. Como almejava um recomeço, a ideia de mudar-se para outra localidade pareceu muito atrativa a Mariana. Afinal, não havia perspectiva de muito progresso no Rio de Janeiro, e ela não possuía vínculos familiares que a segurassem aqui, pelo contrário, havia o histórico de um relacionamento abusivo que a levou à rua. $\mathrm{O}$ primeiro resultado saiu, e seu nome não constava na lista de aprovados. Foi quando o entusiasmo começou a diminuir, embora ainda houvesse esperança de ter seu nome nas chamadas seguintes. Mas sucedeu a segunda chamada, e Mariana estava dentro! Conversou-se novamente, e ela estava disposta a ir. A TSN a alertou sobre as novas dificuldades que surgiriam, os novos desafios a serem superados, mas sua disposição de aproveitar a oportunidade continuava lá.

Foi grande a correria empregada no esforço de fazer os documentos chegarem a tempo da matrícula por procuração. Contudo, uma grande equipe de voluntários/as empenhados/as, tanto no Rio de Janeiro quanto no estado da universidade, fez com que tudo desse certo, e a matrícula foi efetuada. Em uma nova sessão de atendimento psicológico, trabalhou-se com Mariana sua real condição: ela não estava recebendo alta; haveria apenas uma interrupção no acompanhamento, mas ela deveria tentar continuar o tratamento, lá no seu novo estado. Verificou-se, ainda, se ela teria condições/vontade de viajar de avião, o que ela nunca tinha feito, e se realmente estava disposta a essa mudança de vida e ao enfrentamento dos novos desafios vindouros.

Sua passagem aérea foi comprada, e tudo o mais foi providenciado. Em acordo com a universidade, permitiu-se que ela, como caso extraordinário, já entrasse na Casa do Estudante, e só depois concorresse nos termos do edital. Duas semanas depois de iniciadas as aulas, Mariana concorreu à vaga e conseguiu efetivar a sua permanência na residência universitária da instituição, pelo edital corrente. Também obteve o auxílio-alimentação (um valor simbólico para ajudar no custo das refeições, pois a universidade não possui restaurante universitário).

Em março de 2018, Mariana já era uma universitária cheia de sonhos. O contato com a TSN permanece, bem como um pequeno apoio financeiro. $\mathrm{O}$ combinado foi de que ela tivesse um tempo para se organizar e buscar um trabalho 
em meio período que pudesse contribuir para o seu sustento, juntamente com o auxílio-alimentação e o Bolsa Família. Não há como garantir que ela se formará nem que terá qualquer outra conquista relacionada ao seu futuro, mas é fato que Mariana está tendo uma nova oportunidade, socialmente reinserida.

Os casos descritos anteriormente ilustram o trabalho desenvolvido pela TSN e demonstram a complexidade das relações e interações entre as partes envolvidas em um trabalho de reinserção social. Há, como se pôde verificar, inúmeras peculiaridades e possibilidades muito diversas, de acordo com o retorno e as escolhas do/a assistido/a. É fato também que as possibilidades de proporcionar a saída da rua às pessoas em situação de rua interessadas, via TSN, ainda encontram limitações e esbarram na dificuldade social de insuficientes políticas públicas voltadas para a população em situação de rua, por parte do Estado.

Como em todas e quaisquer interações, resta-nos a certeza de que o "sucesso" só é alcançado com a contribuição e o envolvimento das duas partes: voluntários/as da TSN e assistidos/as. Há momentos em que uma não pode agir pela outra pessoa. Ao narrarmos esses dois casos e relermos as notas de campo, fica evidente a importância do princípio da ética no serviço social, chamado de respeito ao "eu soberano". Esse princípio defende a prevalência da autonomia de quem é atendido: nenhuma mudança de estado ou plano de ação podem ser impostos sem o seu consentimento e interesse. É preciso um coenvolvimento de quem atende com quem é atendido/a e uma coconstrução da agenda interventiva centrada na pessoa e em sua autonomia. Os únicos casos em que pode haver medidas compulsórias são os relacionados a problemas mentais. Nesses casos, só os órgãos responsáveis por tal incumbência podem atuar e, mesmo assim, desde que guardadas as devidas medidas de proteção dos direitos humanos.

No próximo capítulo, nos debruçamos, especificamente, sobre a Organização Estrutural Global da interação de abordagem social da TSN e das microações que ocorrem nessas interações. 


\section{Organização estrutural global da abordagem social TSN}

De acordo com as características das interações institucionais (Drew; Heritage, 1992) citadas na subseção 3.4., podemos ratificar que as interações de abordagem social, objeto de estudo desta tese, se configuram como interações institucionais, uma vez que os/as voluntários/as estão engajados/as no mandato institucional de se aproximar, conhecer, ouvir e conduzir proposições que possam propiciar algum tipo de reinserção social aos/às assistidos/as, ainda que também tenham marcas da conversa cotidiana, já que não são interações marcadas pela formalidade.

Por meio da análise de dados, encontramos as seguintes etapas da abordagem social da TSN: 1) início da abordagem, 2) escuta e/ou sondagem, 3) condução propositiva e 4) encerramento. Os nomes escolhidos para as etapas 2 e 3 coincidem com a nomenclatura dada ao que apresentamos no capítulo anterior como as fases 2 e 3 da intervenção social, o que não é de se surpreender, já que a intervenção social é feita por meio da prática de abordagem social.

Algumas abordagens possuem todas as quatro etapas supracitadas em uma mesma interação, mas, apesar da recorrência, essa estrutura não é rígida, há também abordagens que têm apenas as etapas 1,2 e 4 ou 1, 3 e 4 . Além disso, em todos os primeiros encontros, a etapa de sondagem e/ou escuta está presente.

Apresentaremos, nas próximas seções, uma descrição de como os/as interagentes constroem essas etapas interacionais, por meio de excertos que ilustram as microações que ocorrem em cada uma delas. No esforço de manter a relação entre as partes, há ações orientadas para: i) a visibilidade e valorização do outro; ii) a escuta/sondagem e iii) as ofertas do que foi inferido como necessário ou desejado pelo/a assistido/a ou do que foi compartilhado pela própria pessoa atendida.

Como já foi dito, a Turma da Sopa de Niterói tem como objetivo principal a reinserção social, a entrega do alimento é apenas uma forma de criar vínculo com seus/suas assistidos/as. Sendo assim, possui duas equipes: a do alimento e a de Atendimento Social (EAS). Os/as voluntários/as já estão habituados com a rotina dessa divisão e com o fato de a principal atividade da EAS estar focada na conversa, 
embora nem todas as pessoas atendidas tenham essa noção, por não estarem familiarizadas com o processo (Drew; Heritage, 1992). Aqui, nos detemos às (micro)ações realizadas pela EAS.

\section{1.}

Início da abordagem

Schegloff (1968) observa que as aberturas das interações costumam ser uma entrada gradual para o tópico da conversa. Em nosso corpus não é diferente. Nas interações da EAS, a equipe e as pessoas atendidas não iniciam suas interações direcionando-se diretamente ao tópico principal da conversa, salvo nos casos em que se dispensa uma aproximação, por exemplo, pode ocorrer isso quando o/a assistido/a procura o/a voluntário/a para verificar se algo que foi solicitado vai ser conseguido.

No começo da abordagem, há o início da fase de aproximação, identificada e apresentada no capítulo anterior, em que os/as voluntários/as tentam criar um espaço para, na sequência, poderem conhecer melhor a pessoa atendida e poder dar prosseguimento às abordagens. Essa primeira etapa também poderia receber outros nomes como: abertura ou aproximação, mas optamos por "início da abordagem" por considerar um termo mais amplo, que parece se enquadrar melhor ao contexto das interações analisadas.

Os/as participantes da EAS costumam se deslocar até os lugares em que os/as assistidos/as se encontram, para iniciar uma conversa cujo início da abordagem pode ter as seguintes microações: i) chamado-resposta; ii) saudaçãosaudação/apresentação-apresentação e iii) (pré-)oferta de produtos-aceite/recusa ${ }^{45}$. Diante da recorrência dessas ações, nessa primeira etapa, optamos por dividir esta seção de acordo com essas microações, para apresentar como elas podem ocorrer.

\footnotetext{
45 Esta ação encontra-se no início da abordagem por se tratar da EAS, caso a análise fosse das interações da equipe do alimento, ela faria parte do desenvolvimento, uma vez que é o objetivo principal da equipe. Além disso, tais ofertas de itens podem aparecer no meio ou fim das interações caso surja necessidade, mas, em geral, ocorrem no início das abordagens e em alguns fechamentos como veremos na seção 6.4 .
} 


\subsection{1.}

\section{Convocação (Summons)-resposta}

A partir do segundo encontro, as interações tendem a fluir mais, pois os/as interagentes já se conhecem um pouco e podem resgatar informações de seu histórico de conversa, para retomar e fortalecer o vínculo relacional. O par adjacente convocação-resposta, característico de aberturas da conversa telefônica (Schegloff, 1968), também apareceu em nosso corpus, na etapa do início da abordagem, embora não se configure como "obrigatório". Além de a convocação servir para chamar o/a outro/a para uma conversa, pode ter igualmente a função de demonstrar interesse pelos/as assistidos/as, nos casos em que os/as voluntários/as vão ao encontro deles. Nessas situações, essa convocação costuma ser feita usando o nome ou apelido do/a assistido/a ou alguma categorização da pessoa, construída a partir de encontros anteriores, podendo ser considerada uma estratégia de abordagem. "A sequência convocação-resposta é construída e implementada para estabelecer a disponibilidade e o alinhamento do destinatário como destinatário da fala a ser feita" (Shegloff, 2007, p. 58).

No excerto que segue, temos o início da abordagem de um segundo encontro entre a voluntária Merida, ao se deslocar até o assistido Cláudio. Na semana anterior, o assistido havia apresentado alguns de seus trabalhos artesanais e um deles chamou muita atenção, por sua beleza, qualidade e cuidado com cada detalhe: tratava-se de um caminhão produzido com material de reciclagem de latinhas de refrigerante. Foi com base nesse contato inicial que Merida se dirige a ele como "o artista".

\footnotetext{
Excerto 4 - CLÁUDIO_merida_meire_dia13_grav1_ano2

É possível observar que Merida realiza - ainda a certa distância, em volume de voz mais alto - uma convocação ao assistido, por meio de uma categorização que remete ao reconhecimento de seu trabalho como artesão: "OLHA O ARTISTA Aí" 
(1.1). Ele, por sua vez, responde por meio do gesto de voltar sua atenção para ela, aguardando-a chegar mais perto, demonstrando-se disponível para a interação (1.2).

Há, ainda, "convocações" que partem de assistidos/as, seja para convidar algum/a voluntário/a para conversar, verificar alguma solicitação anterior ou encaminhar outro/a assistido/a que possa receber algum tipo de ajuda da TSN. Esse último caso pode ser ilustrado por meio do excerto que se segue, em que a assistida, Luiza, convoca seu companheiro, Luiz Alfredo, para participar da conversa com as voluntárias com as quais ela está interagindo. Depois de ter compartilhado com elas o problema do desemprego de seu companheiro, surge a possibilidade de a ONG fazer cartões para divulgação do trabalho dele, na tentativa de contribuir para que o assistido possa conseguir algum trabalho, mesmo que informal.

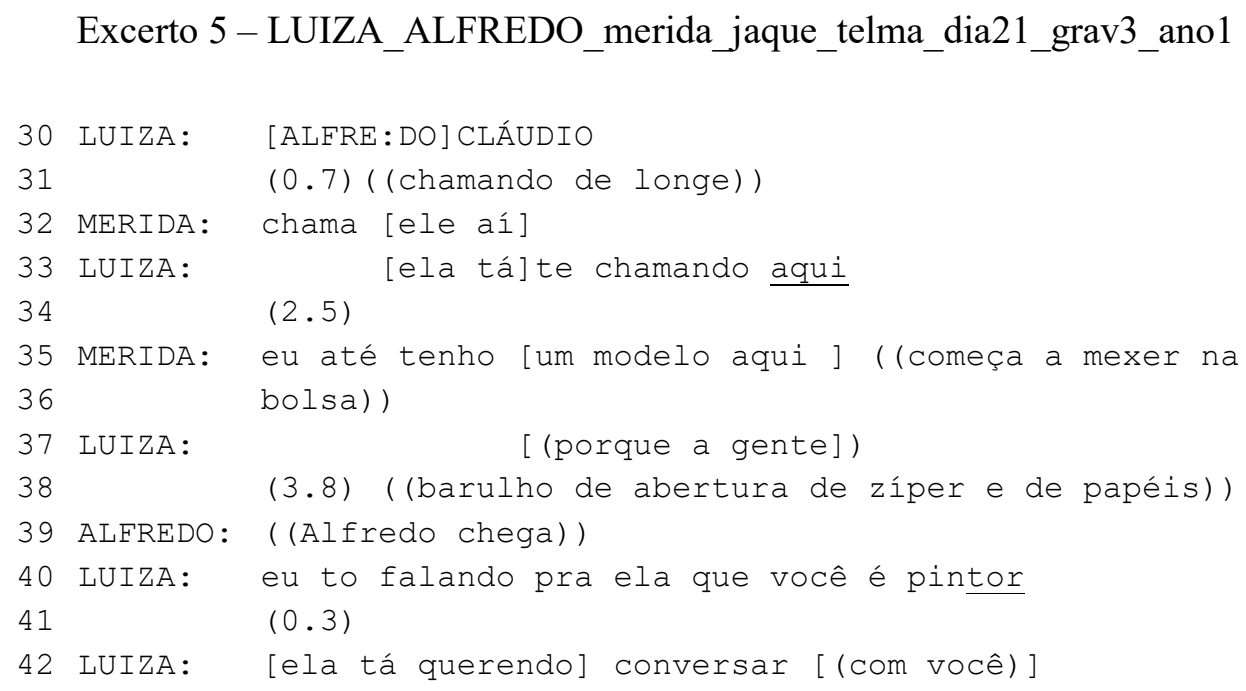

Nota-se, por meio dos comentários de transcrição (1.31) e do chamado, em caixa alta (1.30), que Luiza chama Alfredo em volume de voz mais alto, ainda à distância dele, antes mesmo de a voluntária formalizar o pedido para que ela faça isso (1.32). Para Alfredo, a interação começa quando ele é convocado por Luiza (1.30) e responde com o seu deslocamento, indo ao encontro das voluntárias e de sua companheira, que faz accounts para justificar seu chamado: “[ela tá] te chamando aqui" (1.33); "eu tô falando pra ela que você é pintor" "[ela tá querendo] conversar com você=" $(1.40,42)$, desempenhando um papel de coagente da inclusão de Alfredo na interação. Quando um/a assistido/a se torna esse coagente inclusivo do/a outro/a, costuma facilitar a aproximação, pois se trata de 
um encaminhamento de alguém que já é conhecido/a da pessoa e está indicando a ONG, seja para uma simples conversa/desabafo ou para ajudar na resolução de algum problema.

\subsection{2.}

\section{Saudação-saudação/apresentação-apresentação}

O movimento que pode vir logo após o par chamado-resposta, quando houver, e que costuma iniciar as abordagens sociais ocorre a partir do par saudaçãosaudação, como pode ser observado no excerto 4, linhas 3 ("tudo bem") e 4 ("beleza").

Quando as pessoas ainda não se conhecem, costuma haver, também, apresentações, assim como ocorre na continuação da abordagem ao Alfredo, cujo início foi apresentado no excerto anterior:

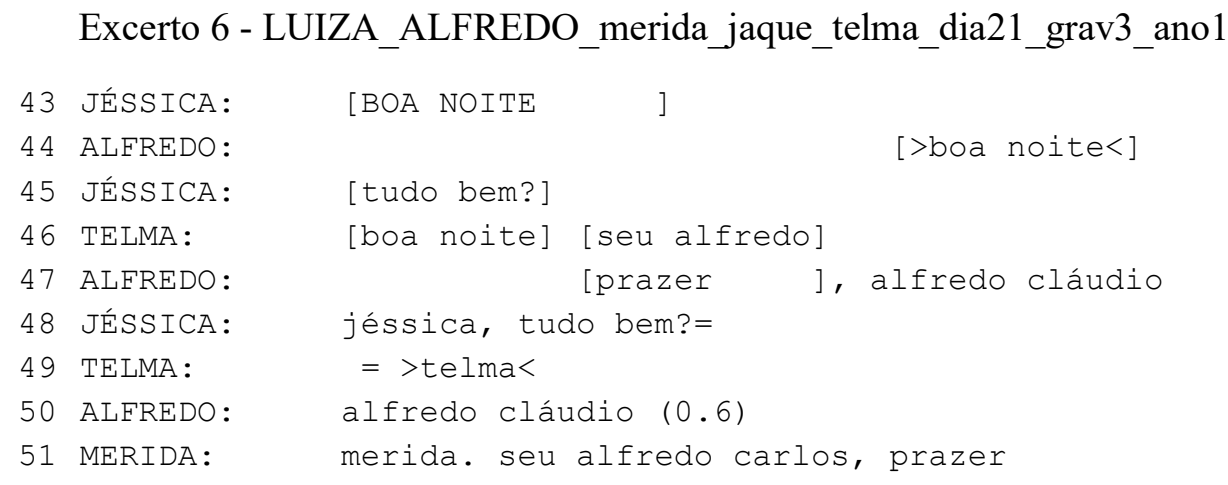

Trata-se de uma conversa com múltiplos participantes e várias sobreposições, que tem um início típico de apresentação entre os/as interagentes. Nesse primeiro contato, entre as voluntárias e Alfredo, há uma sequência multiturnos de troca de cortesias, que se dão por meio das saudações respondidas com saudações (1. 43-48) e das autoapresentações, que se configuram como apresentação de cada um/a (1.4751). Todas as pessoas que ainda não se conheciam dizem os seus nomes e se cumprimentam. É interessante observar que o assistido é quem inicia o ritual de apresentação, mesmo já tendo sido chamado por sua companheira pelo seu nome, usando a clássica expressão "prazer" (1.47), o que desencadeia a resposta das voluntárias, que também se apresentam, embora apenas Merida repita o uso dessa expressão, ao se apresentar (1.51). O uso de “tudo bem” por Jéssica, duas vezes (1. 
$45,48)$, também tem a função de saudação, não chega a ser, emicamente, um questionamento sobre o estado de Luiz Alfredo.

A forma de tratamento usada para as voluntárias se dirigirem ao assistido, em todos os momentos desse primeiro contato $^{46}$, foi "senhor", por meio de sua contração na forma "seu", anteposta ao nome dele (Cunha; Cintra, 1985): "seu luiz (Alfredo)" $(1.46,51)$. Essa forma de tratamento costuma ser usada com pessoas mais velhas, como forma de deferência ou quando as partes não têm muita familiaridade (Brown e Gilman, 1960), conforme aconteceu na interação supracitada, o que demonstra respeito ao Alfredo, pois sua situação de rua não impediu que ele fosse tratado com deferência, necessária nesse primeiro contato.

Mesmo nesse contexto de abordagem às pessoas em situação de rua - que passam por tantas dificuldades e se encontram em situação de vulnerabilidade social -, o cumprimento/saudação comum nos inícios de interações "tudo bem" e suas variações ("tudo joia", "tudo bom”, etc.) é frequente, como consta no próximo excerto, em que as voluntárias Laura e Meire iniciam uma abordagem ao assistido João e à assistida Alice. Esta última não se manifesta, oralmente, no início da interação.

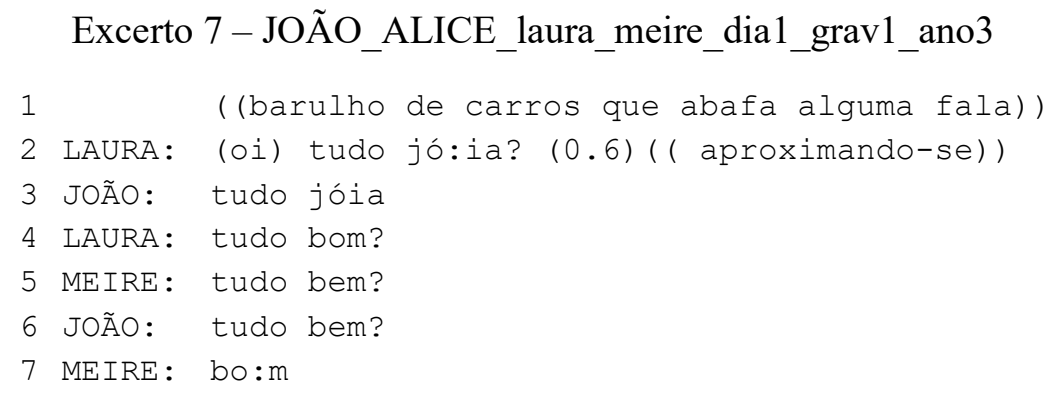

É possível perceber que, ainda distante, Laura chama atenção de João com a saudação: “tudo jó:ia?”, em entonação ascendente, e obtém a repetição da saudação como resposta. Como Aline não responde, ao se aproximar, Laura repete a saudação com outra variação (1.4), seguida de uso similar por Meire (1.5), que, após ter mais uma vez a resposta de João (1.6), faz uma avaliação positiva (1.7). A inicial não manifestação oral de Alice parece ter causado estranheza, já que as

46 Depois de um tempo de contado com o assistido Alfredo Cláudio, a maioria das(os) voluntários(as) o chamava apenas pelo seu nome, sem a forma "seu", o que reforça a justificativa do uso quando se tem pouca familiaridade. 
voluntárias repetiram o cumprimento após ela também não produzir a SPP. Contudo, não podemos dizer que depois da repetição não houve resposta, pois Alice pode ter produzido a SPP a partir de um cumprimento gestual ou de movimento de seu corpo ou olhar, cujo registro não foi possível, por conta de a gravação captar apenas áudio e não haver nenhum registro sobre isso nas notas de campo. É válido dizer que, na sequência da interação, Alice participa ativamente.

Em seguida, trazemos mais um movimento de início de abordagem com saudações, entre a assistida Luiza e a voluntária Merida. Desta vez, quem fala no primeiro turno é a Luiza:

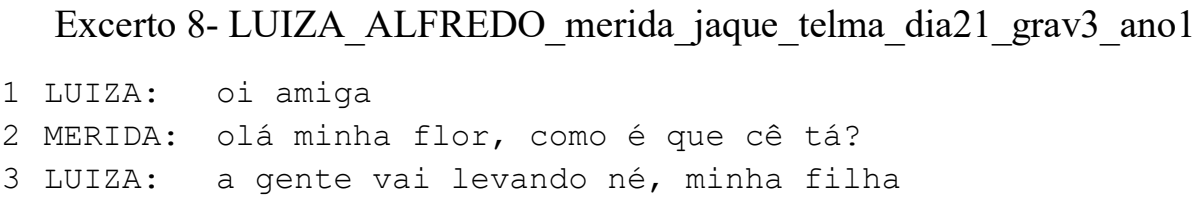

O tipo de saudação produzido como PPP influencia diretamente no tipo de saudação a ser recebida como resposta na SPP e, por isso, nessa interação, há uma troca de formas de tratamento afetivas. Na ocasião, a PPP é realizada por Luiza, com a saudação "oi", seguida da categorização de Merida como "amiga"47 (1.1), que na SPP responde também com afeto, por meio da saudação "olá" seguida da forma de tratamento "minha flor" (1.2). Desta vez, seguida de uma variação da sequência “how are you" (Sacks, 1975): “como é que cê tá?" (1.3), no primeiro turno. Ao responder, Luiza não chega a dar informações precisas de como se sente ou de como sua vida realmente está, mas responde de forma genérica ("a gente vai levando né, minha filha"). Isso não causa estranhamento, pois, como nota Sacks (1975), geralmente, quando as pessoas dizem "how are you" ou variações dessa sequência, não esperamos que, ao responder, a pessoa comece a descrever o seu estado, de fato, salvo em contextos específicos, como em uma consulta médica, por exemplo. O autor defende que, na maioria das vezes, essa expressão e suas variações desempenham exclusivamente a função de saudação. Daí a razão de sua defesa da proposição de que "todo mundo mente", seja por não querer, de fato, saber como a outra pessoa está, ou por não dizer realmente como estamos.

\footnotetext{
${ }^{47}$ A equipe de abordagem já atendeu a uma assistida que disse para a chamarem de "amiga", quando questionada sobre o seu nome. Mas esse não é o caso da interação em questão.
} 
Para finalizar esta seção, apresentamos o início da interação com Penha, fruto de um segundo encontro e do deslocamento da voluntária até a assistida, que se encontrava mais distante, embaixo da marquise que, à época, utilizava como local de dormida. O território em que se dá o início dessa abordagem se distingue dos anteriores. Trata-se de um espaço mais privado, em que as pessoas em situação de rua estão mais afastadas do local onde o transporte da Turma fica estacionado. Ali, os territórios se dividem por meio de papelões. É naquele lugar que Penha dorme, em cima de um papelão, seu espaço, sua "casa".

No primeiro encontro com Penha, estavam várias voluntárias, mas, depois de ser questionada por Merida, em volume mais baixo, se ela era usuária de drogas, a assistida pediu para falar sozinha com ela e respondeu que sim. Mas pediu para que Merida não contasse a ninguém, embora tenha dado permissão para dizer apenas a alguém que pudesse ajudá-la, de alguma forma. Neste mesmo dia, a voluntária já ficou sabendo o motivo de Penha ter ido para a rua e a sua principal demanda, que seria o principal tópico da intervenção, no encontro seguinte.

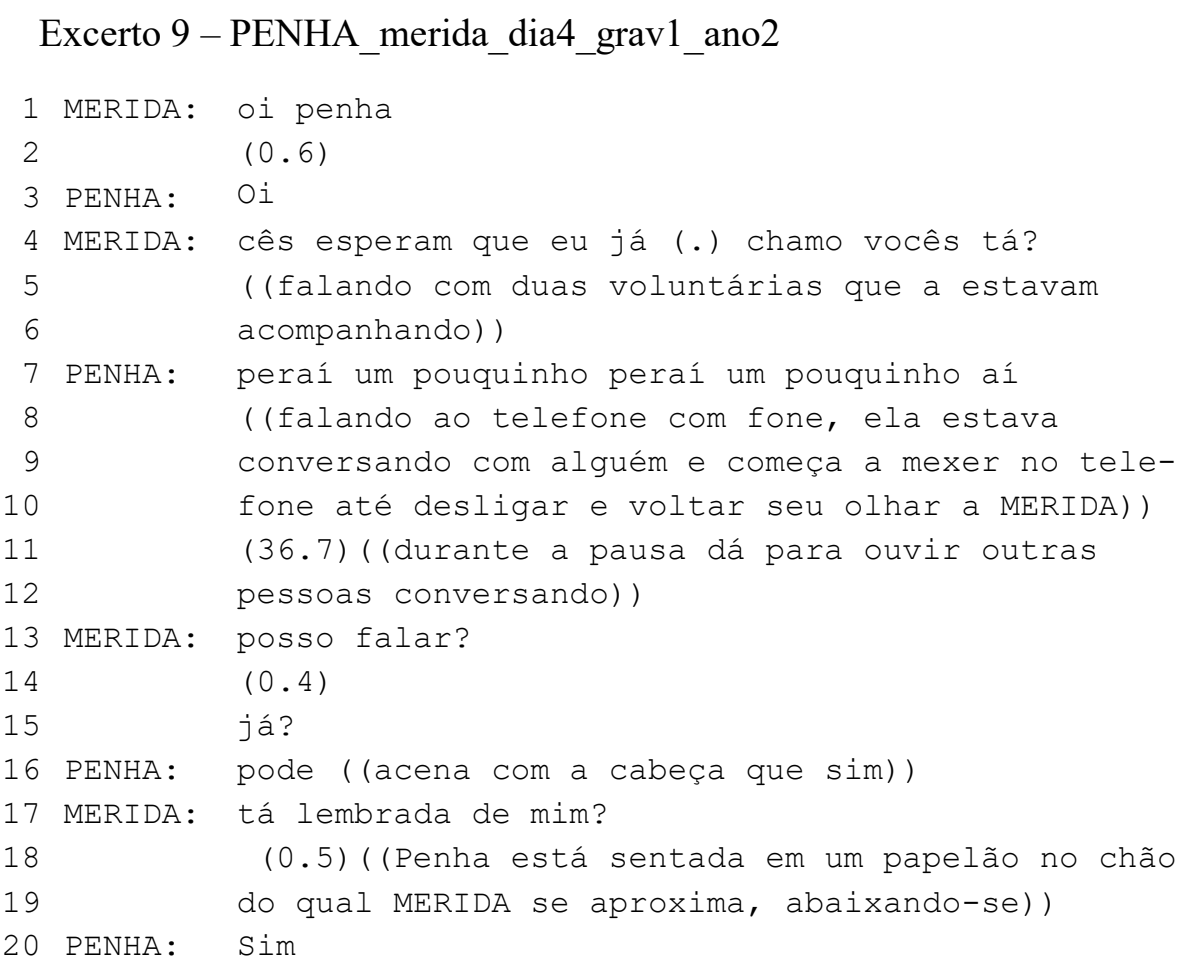

A interação com Penha também se inicia com uma saudação acompanhada do nome dela: “○i penha” (1.1), a qual é respondida após um slot de 6 décimos de 
segundos: “○i” (1.3). Depois disso, há uma mudança de enquadre: Merida se dirige às colegas voluntárias, pedindo que elas aguardem até serem chamadas. Isso permite certa privacidade na interação com a assistida, o que é necessário, por conta do histórico da conversa do primeiro encontro. A identificação de Penha pelo seu nome demonstra que a voluntária sabe quem ela está abordando e a trata em sua individualidade.

Penha estava em outra interação ao telefone cujo encerramento se dá por meio da seguinte fala: "peraí um pouquinho peraí um pouquinho aí" (1.7), como consta na descrição das linhas 8-11. Ela leva 36,7 segundos até voltar sua atenção para Merida, que, em seguida, pede autorização para falar: "posso falar?", "já?" $(1.13,14)$ e a recebe: "pode ( (acena com a cabeça que sim))" (1.15). Na sequência, Merida abaixa-se, para ficar no mesmo nível que ela.

O cuidado e a espera pela autorização de Penha para que Merida pudesse falar pode ser lido como um reconhecimento da não imposição da presença da voluntária naquele local, já que, desta vez, estavam onde a assistida dorme.

É válido destacar, através desse último início interacional, a importante diferença entre um atendimento em algum espaço fechado (gabinete, sede ou domicílio) e na rua, principalmente, quando é no local onde a pessoa dorme. Aqui, o papelão é o que limita o território de Penha. Logo, equivale a uma visita em domicílio, mas "sem porta e sem teto", pois, embora ela esteja em um espaço público, este corresponde ao seu espaço individual. Este necessita de autorização para entrada, tanto que Merida só se abaixa para ficar no mesmo nível que Penha (1.19) depois de esta demonstrar-se disponível, por meio do aceno com a cabeça e da verbalização "pode" (1.16). A linguagem corporal também comunica e o gesto de abaixar-se possibilita que ambas estejam na mesma altura, impede que, fisicamente, a voluntária fale de cima para baixo.

Através do excerto de início de abordagem na interação com Penha, é possível observar mais uma entrada gradual, embora esta seja mais contida do que as anteriores e se prolongue um pouco mais para interagentes que já se conhecem, uma vez que a questão territorial é diferente. Além disso, é válido destacar que, no caso das saudações, quem costuma realizar a PPP é a pessoa que se desloca para iniciar o contato, seja o/a assistido/a, como no excerto 8 , ou as voluntárias, a exemplo dos fragmentos 7 e 9; o 6 poderia ser considerado a única exceção, nesse sentido, mas 
há de se considerar que houve várias sobreposições e o assistido havia sido convocado a ingressar na conversa, de forma que todas as interagentes estavam a sua espera.

\subsection{3.}

\section{Oferta de alimento ou produtos - aceite/recusa}

Dadas as condições da situação de rua, o apoio alimentar é fundamental tanto para a nutrição dos/as assistidos/as quanto para a aproximação das pessoas atendidas. Por isso, mesmo havendo uma equipe responsável pelo alimento, como já dissemos, muitas vezes, o alimento é usado pela EAS na etapa de início de abordagem, inclusive para estabelecer a conversa, até porque fica difícil manter uma interação com alguém que esteja sentido fome. Então, a comida costuma fazer parte da fase inicial, como pode ser ilustrado por meio do excerto que segue.

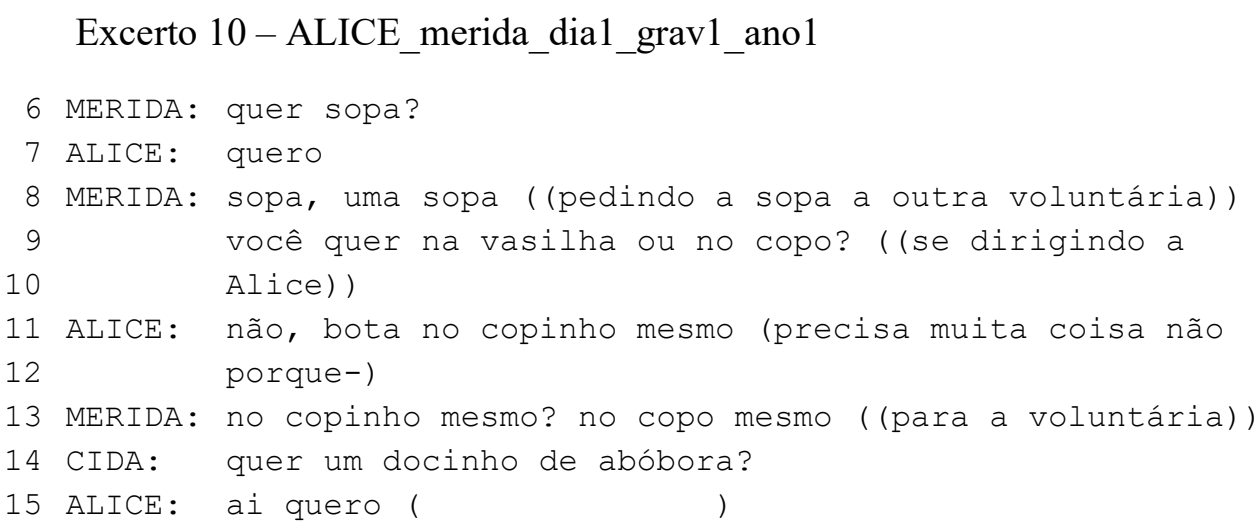

O fragmento dessa oferta ocorreu logo após o reencontro entre a assistida Alice e a voluntária Merida, primeiro elas se cumprimentaram e, na sequência, Merida oferece sopa a ela, por meio de oferta direta (1.6), do tipo "quer X", a qual verifica a vontade/necessidade da assistida em relação ao alimento. Prontamente, ela aceita (1.7). Após negociarem em que recipiente ela receberia a sopa e Merida repassar a informação para algum/a voluntário/a (1.9-13), a voluntária Cida, da equipe do alimento, oferece doce, com o mesmo formato (1.14), também obtendo a aceitação de Alice (1.15). Depois disso, Alice recebe o alimento e começa a comer, continuando a conversar com Merida. Uma vez que a assistida esteja alimentada e 
elas já se conhecem, a aproximação está estabelecida e a interação consegue passar para as próximas fases.

Por fim, destacamos algo que ocorre em praticamente todas as microações: tratar os/as assistidos/as por seus nomes. Essa postura parece ser algo muito importante para os interagentes. Chamar os/as assistidos/as pelos seus nomes faz parte das estratégias de aproximação que são usadas nas abordagens sociais da TSN, tanto que vemos o uso do nome do/a assistido/a nos excertos 5, 6 e 9; nos excertos 4, 8 e 10 os nomes não aparecem, mas, no decorrer da interação, eles surgem, antes e/ou depois dos excertos.

Essa costuma ser uma conduta comum assim que se descobre o nome da pessoa atendida, na primeira interação, salvo em casos de esquecimentos. Os/as próprios/as assistidos/as já demonstraram, interacionalmente, a relevância de serem identificados pelos seus nomes, manifestando-se tanto em relação à presença de sua identificação quanto pela ausência dela. No diário de campo constam exemplos de registros de ambos os casos. No primeiro, um dos moradores em situação de rua, após ser cumprimentado com seu nome, gritou, sorridente: "Você lembra de mim? Lembrou do meu nome! Ela sabe quem eu sou!”. Seu entusiasmo demonstrou surpresa e emoção. No segundo, em uma das interações, uma assistida reclamou que já tinha dito o nome dela à voluntária mais de duas vezes, e que, portanto, seria a última vez que diria. Esses relatos mostram o quanto esse tipo de identificação é importante, pois, ao serem chamados/as pelos seus nomes, os/as assistidos/as percebem que sua individualidade é notada, deixando de ser invisíveis, ainda que por alguns instantes.

\section{2.}

\section{Escuta e/ou sondagem}

A primeira questão relevante aqui é diferenciar a escuta da sondagem, embora façam parte de uma mesma fase e possam ocorrem em uma mesma sequência. $\mathrm{Na}$ escuta, o/a assistido/a é que voluntaria o tópico ou a narrativa, enquanto na sondagem é o voluntário/a que faz isso, por meio de pedidos de informações, como poderá ser observado nos dados. Nos dois casos, há uma ratificação do "eu" do/a outro/a e a obtenção de informações sobre o/a assistido/a orientada para condução propositiva. 
Após o início da abordagem, em que podem ocorrer as microações apresentadas na seção anterior, entra-se no tópico da conversa (algo da vida do/a assistido/a), o que pode ser introduzido pelo assistido ou pelo voluntário. Em qualquer dos casos, são momentos muito importantes para o/a voluntário/a, pois é assim que se torna possível conhecer melhor a situação do/a assistido/a, suas demandas e o seu desejo ou não de sair das ruas ou de voltar para casa, bem como o que os impede. É com base nessa escuta que ações propositivas são projetadas, na mesma interação ou em outras.

Assim, por meio desta etapa, é que se tenta conhecer mais sobre a pessoa atendida, suas necessidades, seus sofrimentos, sua história de vida. Para isso, é muito importante estabelecer algum vínculo com o/a assistido/a e reforçar aqueles que já existam. Essa escuta e/ou sondagem pode ocorrer não só na passagem para o tópico da conversa, mas ao longo da interação, isto é, entre as ofertas de ajuda, que se caracterizam como conduções propositivas. Aqui, mostramos apenas alguns fragmentos que ilustram como se dá essa fase logo após o início da abordagem e um deles, o último excerto, quase no final dela.

A sondagem pode ter como tópico inicial algum conhecimento anterior sobre quem é o assistido. Nesses casos, pode haver uma sequência de Pergunta-Resposta (PR), que, além de obter informações, serve para demonstrar interesse pelo outro, enaltecer algum aspecto pessoal, alguma experiência, criando condições para o estabelecimento de uma relação de confiança. É o caso do fragmento que segue, da abordagem ao Cláudio, em encontro posterior à apresentação de seus trabalhos artesanais com materiais recicláveis.

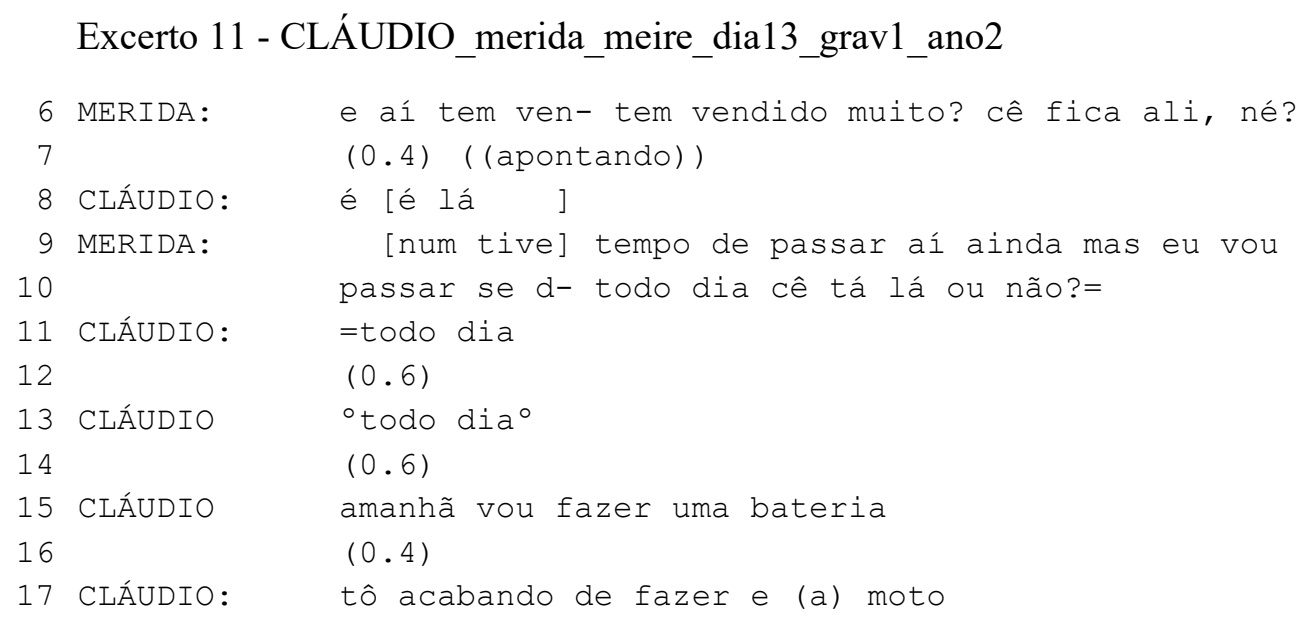




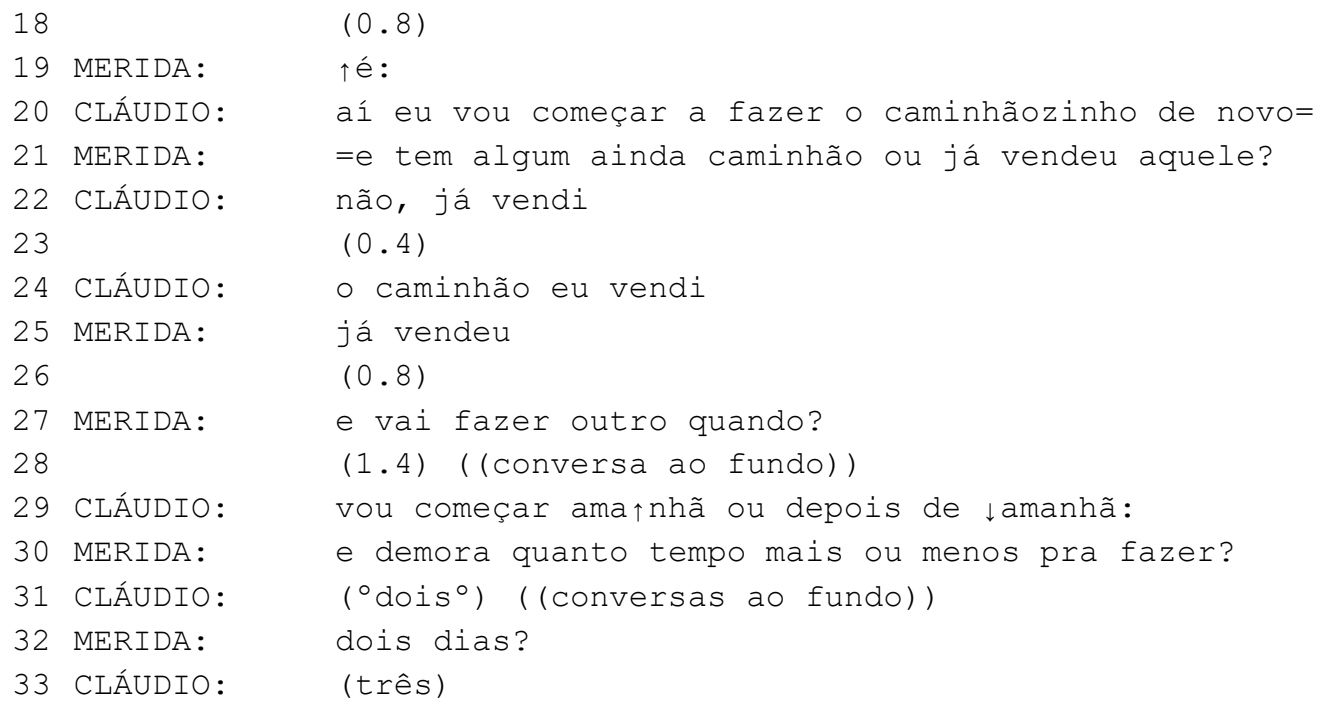

O excerto apresentado ocorreu logo após a abertura da conversa entre Cláudio e a voluntária Merida. Há uma tentativa de demonstração de interesse, reafirmada por meio de multiturnos de Pergunta-Resposta (PR) sobre o trabalho desenvolvido por Cláudio, que se estende da linha 6 à 32, em busca de informação sobre a produção de Cláudio, que pode contribuir para uma ação propositiva, em outro momento e, principalmente, demonstra interesse pelo assistido. Todas as PPP foram realizadas pela voluntária e as SPP pelo assistido.

Merida faz uma sequência de perguntas polares ${ }^{48}$ relacionadas ao seu ofício e aos produtos feitos por ele, que poderiam ser respondidas com "sim", "não" ou equivalente: "e aí tem ven- tem vendido muito? cê fica ali, né?" (1.6), “todo dia cê tá lá ou não?" (1.10), "=e tem algum ainda caminhão ou já vendeu aquele?" (1.21) e perguntas $Q U$ - de Tipo Específico ${ }^{49}$, que buscam resposta contendo informações específicas: “vai fazer outro quando?” (1.27) "e demora quanto tempo mais ou menos pra fazer?" (1. 30). Todas essas perguntas foram respondidas por Cláudio, fornecendo não só as informações solicitadas, mas também acrescentando elementos que não tinham sido solicitados ("amanhã vou fazer uma bateria", "tô acabando de fazer e (a) moto") $(1.15,17)$, o que demonstra engajamento entre assistido e voluntária. Note que a maioria das vezes em que houve atraso das SPP há anotações de campo que

\footnotetext{
${ }^{48}$ Heritage (2010) define a pergunta polar como uma pergunta declarativa de "sim" e "não".

49 Fox e Thompson (2010) definem esse tipo de pergunta como aquela que busca elementos específicos de informação.
} 
poderiam justificar esses atrasos $(1.7,28)$, sem se configurar em desalinhamento por parte do assistido. Além disso, mesmo quando há pequenos espaços relevantes de transição após pequenas falas de Cláudio (1.12,14,16,23), Merida não toma o turno, dando oportunidade de ele acrescentar mais informações.

A demonstração de interesse por parte da voluntária é reforçada, logo depois de uma pausa ocorrida após o acréscimo de informação de Cláudio, pelo sinal de retorno dado por meio do “†é:” (1.19) prolongado e ascendente, que serve como convite para prolongar a fala de Cláudio, que continua a narrar: "aí eu vou começar a fazer o caminhãozinho de novo=" (1.20) e a responder às perguntas que surgem. Essas sequências de pares adjacentes de Pergunta-Resposta que ocorrem até a linha 33, além de demonstrarem interesse pelo assistido, trazem informações que podem contribuir para uma ação propositiva, em outro momento.

Em meio a essa sequência de PR, Merida introduz uma prestação de contas: “[num tive] tempo de passar aí ainda” (1. 9). Dessa forma, a voluntária se posiciona como alguém que tem contas a prestar, já que conheceu o trabalho do assistido, mas não voltou ao local onde ele vende os produtos. A ação reparadora da possível ofensa se completa com a promessa indireta de corrigir o erro, indo futuramente ao encontro do morador: "mas eu vou passar [...]" (1.9-10).

É válido notar que, quando já houve um contato anterior, os/as voluntários/as da equipe de abordagem já têm informações do/a assistido/a e podem usá-las para criar um vínculo maior e identificá-lo/a por seus nomes e por suas características pessoais, assim como no excerto apresentado. Tanto que Merida utiliza informações do encontro anterior para demonstrar que se lembra dele como indivíduo, inclusive chamando-o pelo nome (excerto 4, 1.3), e a categorização é estabelecida por meio dos pontos fortes dele (excerto 4, 1.1). É dessa relação anterior que resultam todas as Perguntas-Respostas que aparecem e as primeiras sondagens da abordagem, daquela noite, ao Cláudio.

Essa etapa da abordagem pode ser de tamanho variado, durar instantes ou, praticamente, toda uma interação. No excerto seguinte, o tópico - profissão do assistido - foi introduzido pela esposa de Alfredo, Luiza, que compartilhou o problema do desemprego de seu marido e as dificuldades financeiras do casal com as voluntárias Merida, Jaque e Telma. Neste caso, ao ouvir Luiza, o esposo dela 
também foi convidado para participar da interação. A escuta apresentada abaixo foi provocada por meio de uma sequência de pedido de informação-resposta:

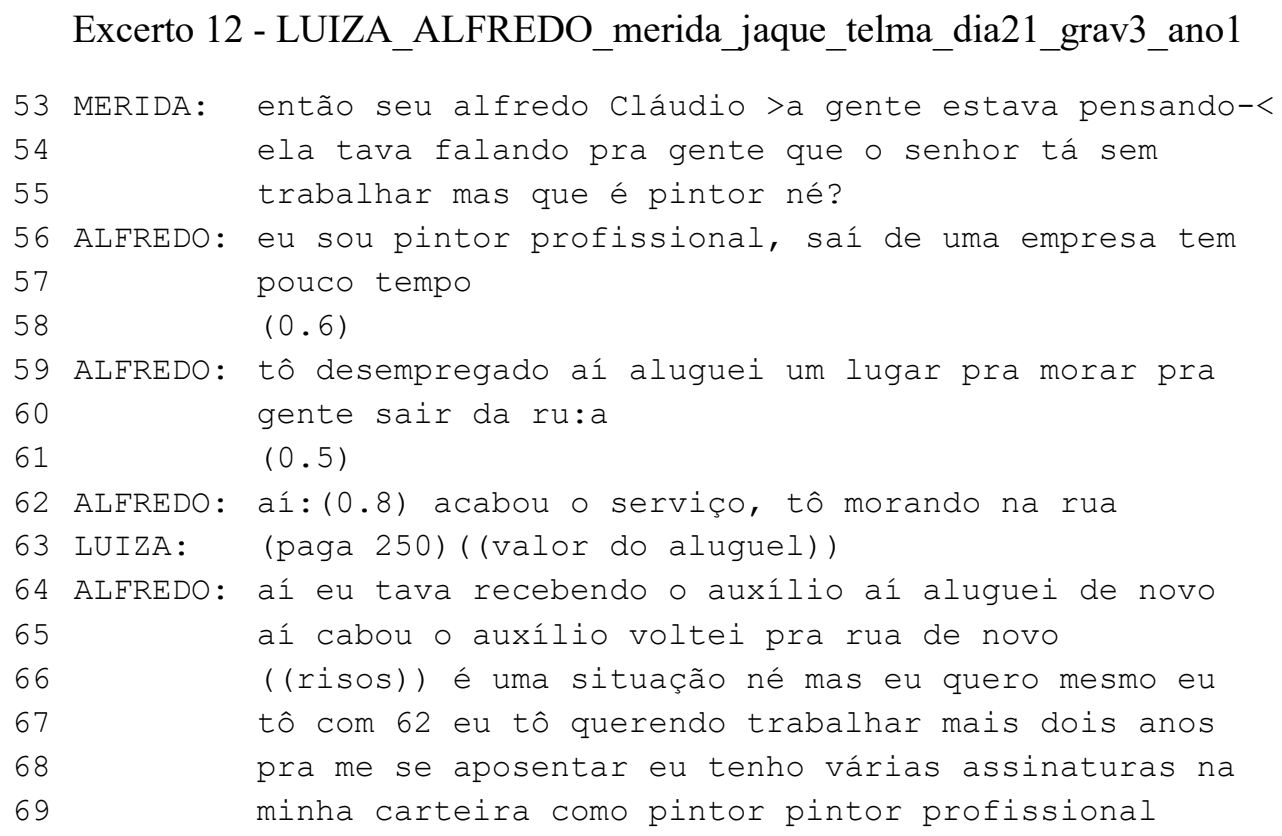

É possível notar que, dessa vez, Merida começa com uma sondagem: pedido de confirmação da situação profissional do assistido, recuperando informações passadas pela companheira do assistido (1.53-55) e, depois, o assistido traz uma sequência de vários turnos de narrativa, que as voluntárias escutam atentas. Desta forma, além da confirmação ("eu sou pintor profissional” 1.56), Alfredo compartilha com as voluntárias os detalhes do problema pelo qual estão passando, respondendo à Merida com acréscimos que se configuram em uma pequena narrativa sobre sua situação ("saí de uma empresa tem pouco tempo"1. 56-57 e 1. 59-60, 1.62, 1.64-69). As voluntárias não interrompem o assistido, mesmo nos pequenos locais relevantes de transição $(1.58,61)$, elas não tomam o turno, permitindo que Alfredo compartilhe seus problemas, algo muito importante para as próximas etapas da abordagem. Inclusive, Luiza contribui (1.63) com acréscimo de informação à fala de seu companheiro.

É importante dizer, ainda, que o primeiro turno de Merida (1.53-55) também funciona como um pré-anúncio sobre a possibilidade de a TSN fazer cartão de visitas ao assistido, como poderá ser visto no primeiro excerto da seção 7.2. 
Apresentamos, a seguir, um excerto da abordagem à assistida Ester, em que há uma sondagem muito comum em abordagens nas quais o/a voluntário/a ainda não ouviu nenhuma narrativa sobre os motivos que levaram a pessoa para a rua. Isso é feito por meio de pedido de informações:

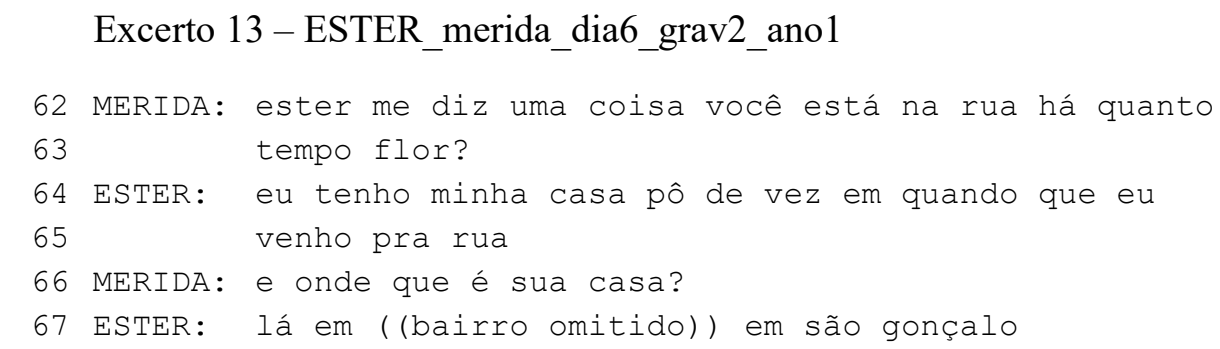

No excerto acima, vemos que, por meio da sequência de PR, Merida consegue obter mais informações sobre a assistida. Na PPP, ela faz uma pergunta $Q U$ - de Tipo Específico, muito comum nas abordagens sociais para saber há quanto tempo a pessoa se encontra em situação de rua (1.62-63). Para isso, usa o nome da assistida e uma categorização afetiva "flor", como SPP obtém uma explicação sobre a sua condição, informando que tem para onde ir e que só vai para a rua de vez em quando (1.64), o que gera um novo pedido de informação de Merida, também com outra pergunta $Q U$ - de Tipo Especifico (1.66), a qual é respondida concedendo a informação (1.67). De posse das respostas de Ester, a voluntária vai sabendo mais sobre ela, a conversa flui, é possível tentar descobrir seus pontos fortes para usar nessa e em outras interações e, posteriormente, fazer as conduções propositivas que julgar convenientes.

Destarte, durante as diferentes sequências de PR comuns à sondagem, as voluntárias vão obtendo mais informações sobre a situação dos/as assistidos/as e demonstrando interesse sobre as pessoas atendidas e suas vidas. No atendimento que segue, as voluntárias Meire e Laura estavam conversando com Alice e buscando mais informações sobre a situação da sua inscrição no Programa Minha Casa Minha Vida, no qual a assistida havia dito, em outro momento, estar inscrita.

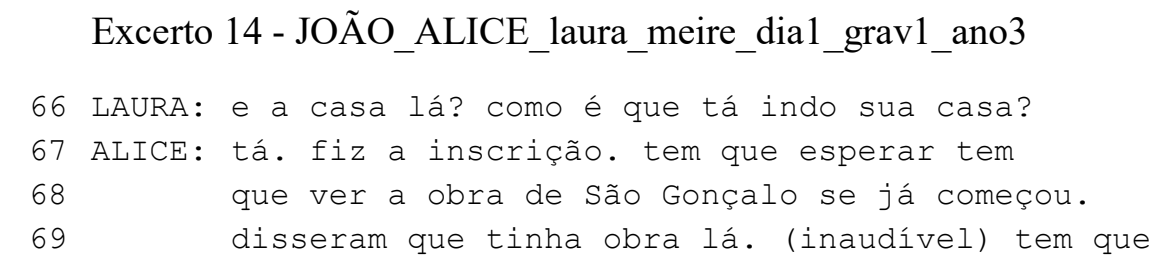




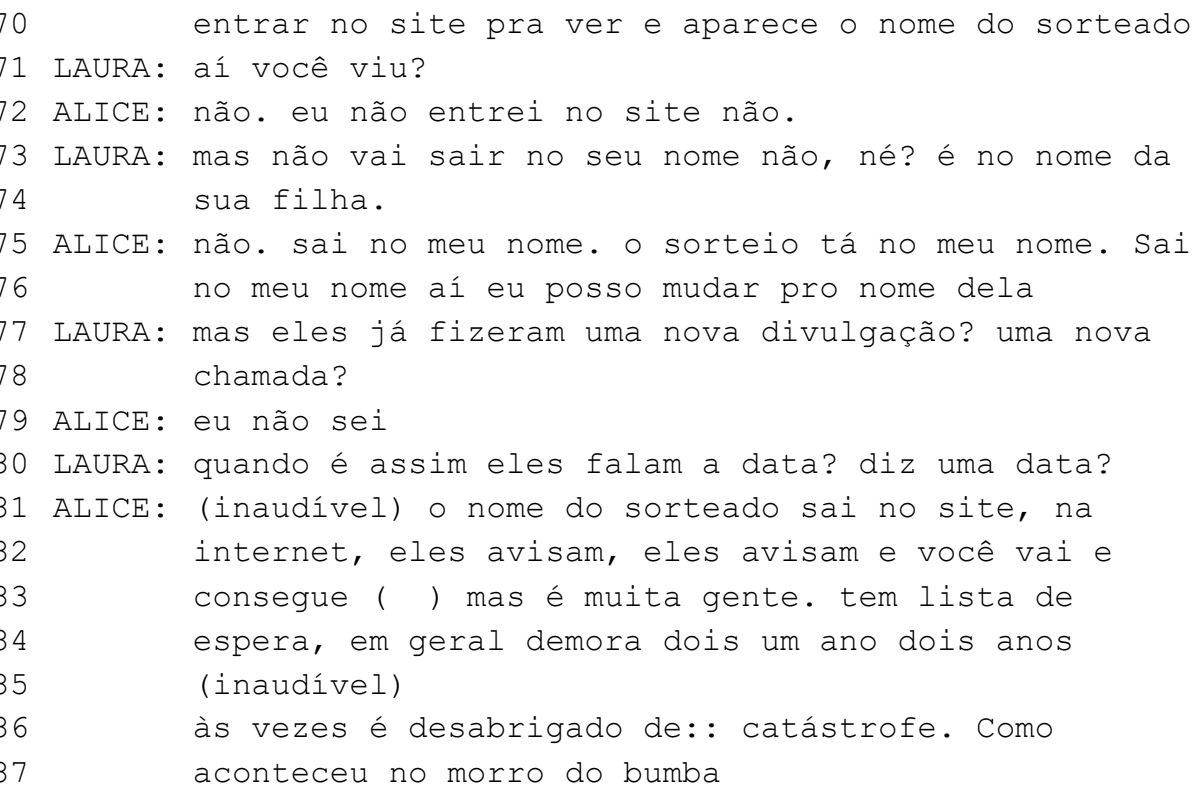

Todo esse excerto de PR acima consiste, basicamente, em pares de pedidos de informação-informação, em que a voluntária Laura é responsável por realizar as PPPs $(1.66,71,73,77-78,80)$, enquanto Alice é responsável pelas SPPs. Podemos notar que apenas a primeira pergunta de Laura foi mais aberta e a que teve uma resposta com mais informações. As outras perguntas feitas por ela foram polares $(1.71,73,77-78,80)$, consequentemente, a maioria das respostas foram curtas e rápidas, tendo como exceção a última, respondida com bem mais informações do que as solicitadas. No caso da assistida em questão, como ela costuma falar bastante, mesmo nas respostas mais curtas, ela seguia acrescentando informações a mais do que as solicitadas, o que proporciona que as voluntárias saibam mais da assistida.

Quando se trata de busca de informações sobre um tópico específico, como nos excertos 13 e 14, é comum que ocorram perguntas polares, o que, a depender do/a assistido/a, pode diminuir a quantidade de suas contribuições e de possíveis compartilhamentos de problemas.

Trazemos, em seguida, um excerto de mais uma sondagem que, além da sequência de PR, traz ações afiliativas, que desencadeiam turnos maiores por parte da assistida e leva ao que chamamos de escuta ao assistido. Essas ações são muito importantes nessa etapa, justamente para que a pessoa atendida fique à vontade para partilhar seus problemas. Trata-se da interação entre Penha e Merida, no momento 
em que elas estão falando sobre a vontade de Penha parar de usar drogas e suas dificuldades para isso; a questão das drogas surgiu na abordagem anterior à Penha. Antes do fragmento abaixo, elas conversaram sobre a possibilidade de Penha começar atendimento psicológico e a equipe do alimento havia acabado de entregar refrigerante a Penha e se despedido.

Excerto 15 - PENHA_merida_dia4_grav1_ano2

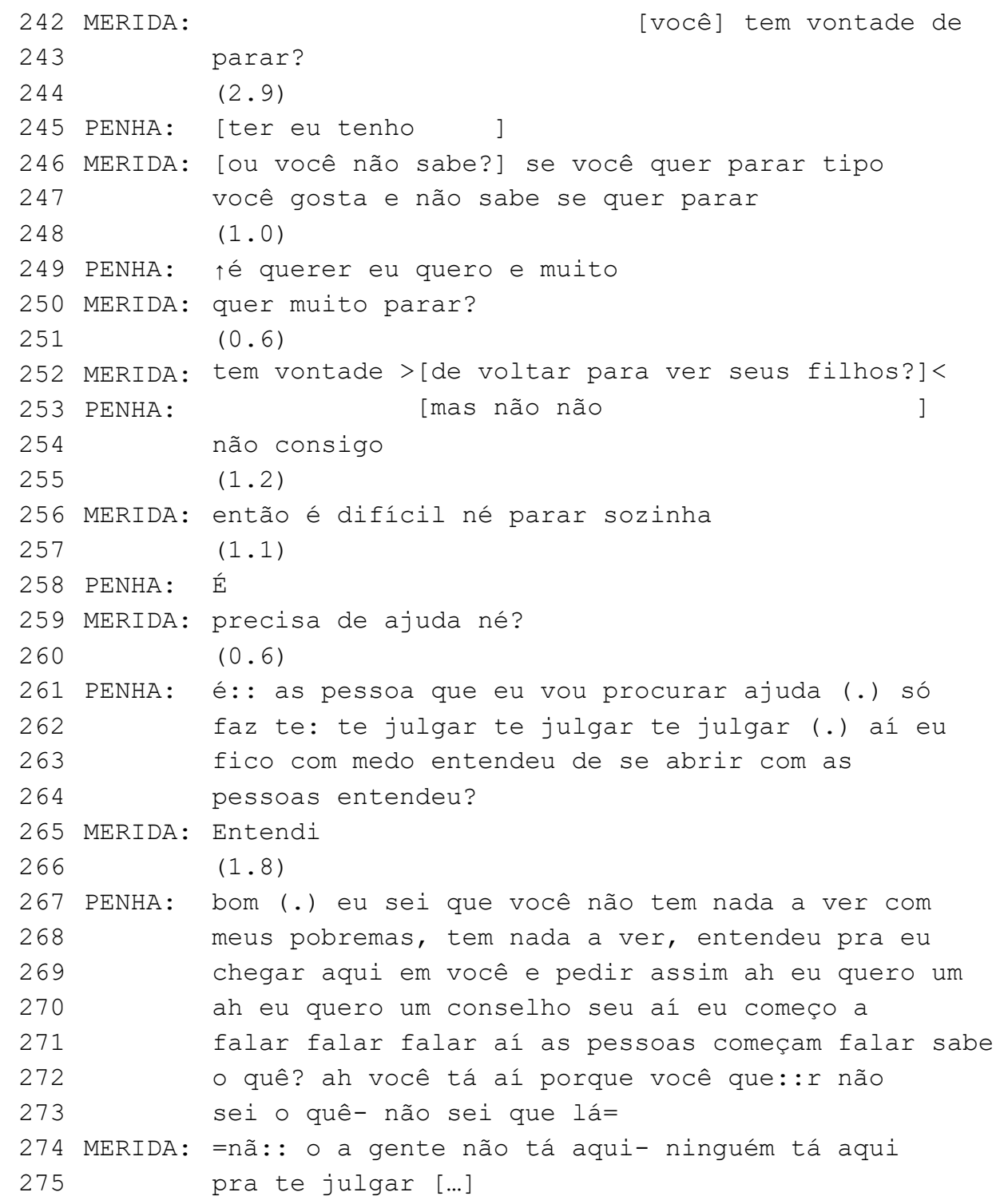

A escolha desse excerto também serve para mostrar o quanto a aproximação é fluida, construída e reforçada a cada atendimento social, pois, na maior parte dessa interação com Penha, suas contribuições eram mínimas, elas foram aumentando com o desenvolver da interação até que tiveram desabafos como os apresentados 
nesse excerto. O tópico do uso de drogas é delicado (Ostermann e Rosa, 2012), o que pode ser confirmado por meio das longas pausas em Locais Relevantes de Transição $(1.244,248,251)$, quando o tópico é tornado relevante nas perguntas feitas pela voluntária sobre parar de usar drogas. Apesar disso, como Merida não toma o turno novamente, a cada PPP realizada, ela espera que Penha realize as SPP, o que ocorre com atraso. Em outras palavras, devido à demora de quase três segundos por parte da assistida para responder a pergunta polar sobre sua vontade de deixar de ser usuária de drogas, Merida expande a sequência interacional, recorrendo à pós-expansão não mínima (Schegloff, 2007), em que ela reformula a pergunta ("[ou você não sabe?] se você quer parar tipo você gosta e não sabe se quer parar" 1.246-247), em sobreposição com a resposta em atraso de penha: “[ter eu tenho]" (1245), que, após um segundo, é fortalecida “†é querer eu quero e muito" (1.249) com declaração de desejo de sua parte, que parece estar faltando alguma concessão, a qual é concluída após a repetição da fala dela por Merida, com entonação de pergunta (1.250), um LRT e mais uma reformulação a respeito "tem vontade >[de voltar para ver seus filhos?]<", por meio da seguinte fala concessiva: “[mas não não] não consigo" (1.253-254). Essas declarações por parte da assistida são de extrema importância para a abordagem social, pois, para que tenha sentido qualquer tipo de condução propositiva, é importante que a pessoa atendida expresse interesse em mudar sua situação.

Toda a fala da voluntária é feita com recuperação de informações já sabidas por ela: de que a assistida é usuária de drogas e de que tem filhos em outra cidade, os quais não são vistos há algum tempo, por conta do problema com seu vício. Daí as perguntas em cascata (Clayman; Heritage, 2002), isto é, em um único turno de fala e relacionados ao mesmo tópico ("quer muito parar?", “tem vontade [de voltar para ver seus filhos?]" 1.250,252) que possibilitaram que a assistida expressasse sua dificuldade em mudar sua condição.

Desse excerto de sondagem, ainda é importante destacar a afiliação da voluntária ao problema compartilhado ("então é difícil né parar sozinha" 1.256), incrementado de forma atenuada por meio do pedido de confirmação mediante a tag interrogativa sobre a necessidade de ajuda da assistida "precisa de ajuda né?" (1.259). Só depois desse movimento afiliativo é que Penha produz um 
turno maior, trazendo um desabafo que é também o compartilhamento de seu problema, iniciado por uma confirmação fraca por intermédio do alongamento do “é: :" seguido de possíveis justificativas que fazem com que ela não busque ajuda (1.261-264, 267-273). Em cada oportunidade, Merida segue demonstrando afiliação (1.265 e 274-275) e, em fala colada, tenta afastar a ONG, representada por ela, daqueles que só a julgam; na sequência da fala da voluntária, omitida, ela valoriza o fato de a assistida confiar nela para compartilhar seus problemas e ter confiança, já que aceitou que essa interação estivesse sendo gravada. Assim, a escuta à assistida se concretiza e há um estreitamento dos laços de confiança entre as interagentes, que podem ser constatados no final dessa interação e nas próximas abordagens à Penha.

Para finalizar, apresentamos um fragmento da abordagem ao Cláudio, em que foram surgindo vários assuntos, inclusive uma autodescrição profissional da parte dele, quando emergiu o tópico sobre mercado de trabalho $\mathrm{e} o$ compartilhamento de um problema: não ter nenhum documento, como veremos a seguir.

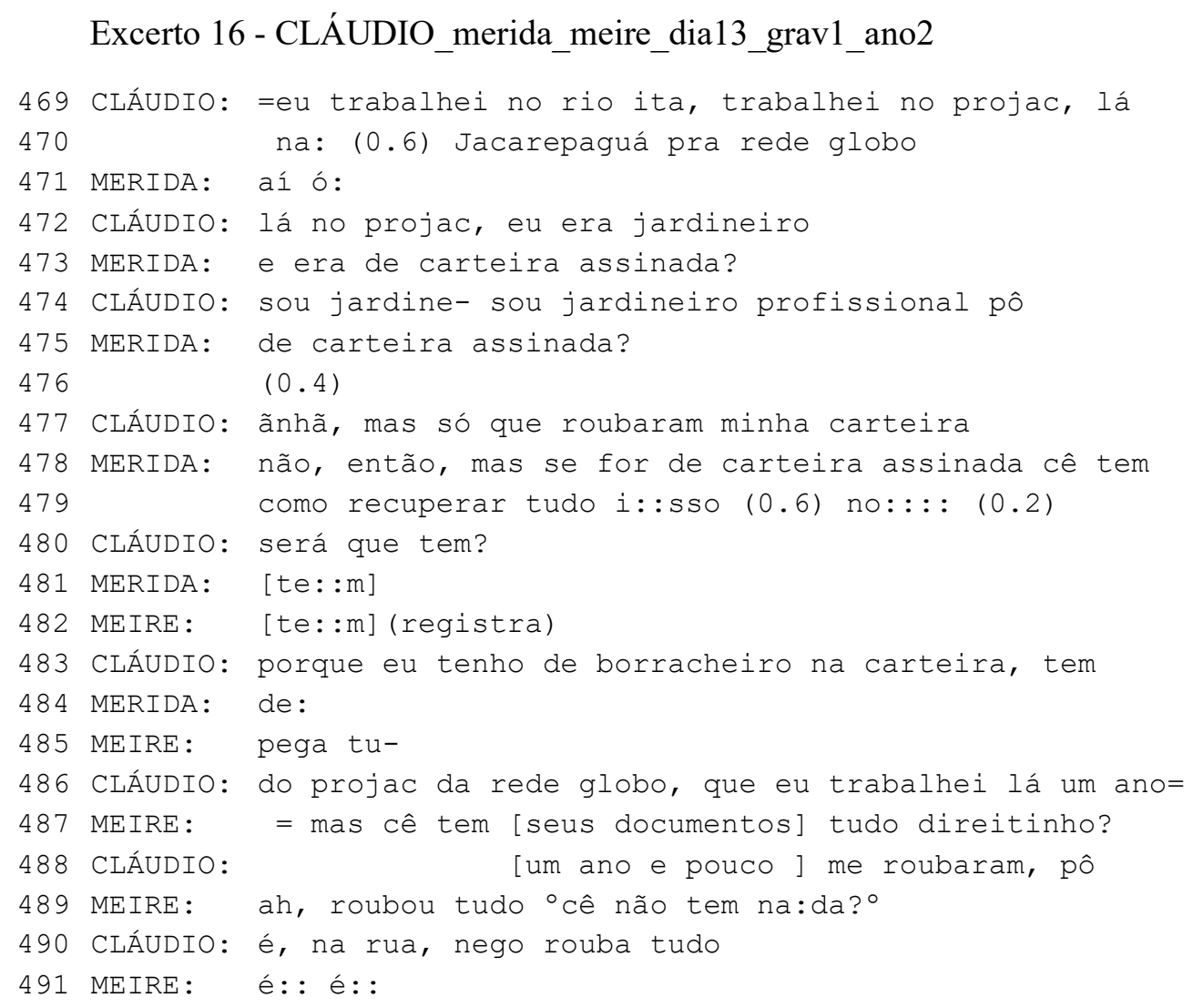




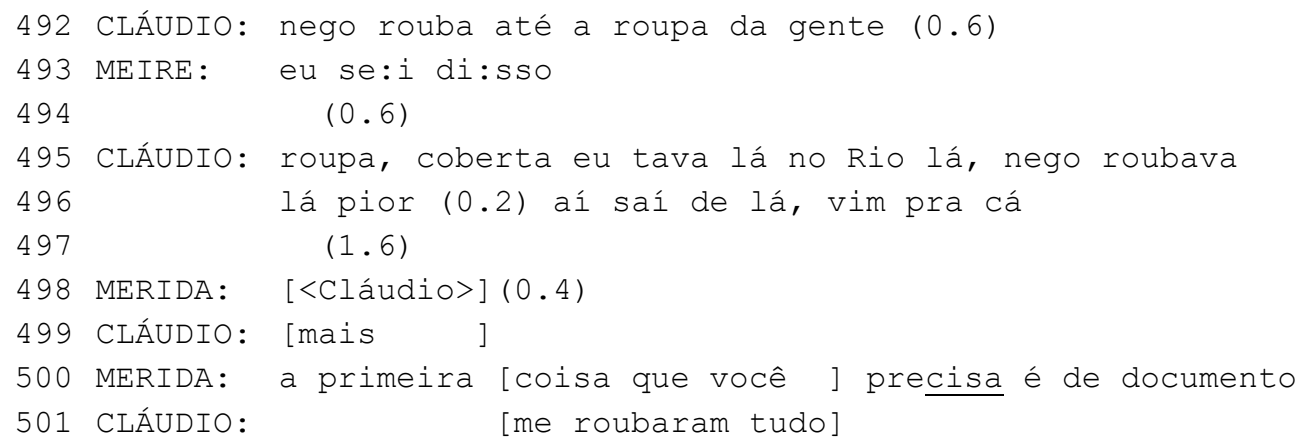

Cláudio narra parte de sua vida profissional, algo que não havia feito, até então. Ele conta, inclusive, ter trabalhado em um complexo de estúdios da $T V$ Globo, muito conhecido no Brasil, o Projac (1.469-470). Na sequência, Merida faz uso de um continuador, incentivando-o a prosseguir com sua história: "aí ó:" (1.471). Enquanto Cláudio segue, as voluntárias ouvem atentas, e fazem pequenas interferências visando a obterem mais esclarecimentos. Podemos dizer que trata-se de uma sondagem de pesquisa na qual Merida busca mais informações sobre a atuação profissional citada, questiona se os ofícios foram registrados na carteira de trabalho do assistido mediante um pedido de informação por meio de uma pergunta polar (1.475), ao que recebe, a princípio, uma resposta indireta. A partir da ênfase dada em sua categorização profissional, poderia ser analisada como uma resposta afirmativa (1.474). Apesar disso, a voluntária insiste no pedido de informação (1. 475), buscando fazer com que Cláudio produzisse a segunda parte do par adjacente com "sim"/"não" ou equivalente, resposta dada e acrescida da informação de que o documento havia sido roubado (1.477).

Vemos, mais uma vez, que a pergunta polar costuma ser eficiente quando se procura uma informação especifica que possa ser importante para o desenvolvimento da abordagem. Quando os assistidos estão engajados na abordagem, eles contribuem acrescentando informações que podem servir para fundamentar conduções propositivas a posteriori, de modo que as voluntárias descobriram que Cláudio não tem nenhum documento, tornando clara a necessidade imediata do assistido: a retirada de documentos que possibilitem a busca de um trabalho ou algo do gênero, imprescindível à sua reinserção social. Ao ficarem sabendo que ele foi roubado e não tem mais nenhum documento $(1.488,501)$, Meire usa marcadores de concordância $(1.491,493)$ que demonstram afiliação 
(Mandelbaum, 2013) ao que ele está narrando e servem como continuadores da narrativa; também podem reforçar o vínculo entre as partes e conquistar ainda mais a confiança do assistido. Depois de uma descoberta desse tipo, o passo seguinte é a orientação de como o Cláudio poderia retirar a segunda via de todos os documentos, foi o que ocorreu na sequência da interação.

Assim sendo, as microações na etapa de escuta e/ou sondagem têm em comum a demonstração de interesse pelo outro e a busca de informações do/a assistido/a, mediante sequências de Pergunta-Resposta e, sempre que possível, demonstrações de afiliação. Com essa etapa, os/as voluntários/as passam a conhecer mais sobre aqueles/as que atendem para que proponham ofertas de ajuda que, de alguma forma, possam ser relevantes para as pessoas atendidas.

\section{3. \\ Condução propositiva}

Em termos de ação, a condução propositiva é o nome dado à fase em que há uma grande variedade de ofertas de ajuda. Em resumo, as conduções propositivas referem-se às ofertas que os/as voluntários/as entendem que podem ser necessárias ou desejadas pelas pessoas atendidas. Já que as ofertas de ajuda se mostraram uma ação quase que central nas abordagens sociais, reservamos os dois próximos capítulos para tratar apenas dessas ofertas e apresentar dados que ilustram a sua recorrência, separando-as conforme a organização preferencial, mostrando suas implicações interacionais. Assim, apresentamos algumas possibilidades de ofertas que possuem formato preferido, no capítulo 7, e despreferido, no 8.

\section{4 .}

\section{Fechamento das interações}

Como parte de um programa de trabalho realizado por vários anos para explorar a possibilidade de alcançar uma disciplina naturalística passível de observação, que pudesse lidar com os detalhes da(s) ação(ões) social(is) de maneira rigorosa, empírica e formal, Schegloff e Sacks (1974) abordam a Organização Estrutural Global das conversas, com ênfase no fechamento das interações, ocasião 
em que uma conversa cotidiana é encerrada ${ }^{50}$. Assim, descrevem características/técnicas de encerramento dos/as interagentes e afirmam que há dois elementos estruturais obrigatórios e dois não-obrigatórios, mas muito comuns.

Os obrigatórios são:

1) troca entre os/as interagentes de um ou vários pares de elementos de préfechamento ${ }^{51}$, tais como “tá bom então", "então tá”, “tá certo então", “ok”, “tá" e "tá bem/bom” ou anúncios explícitos de fechamento que interrompem/suspendem o tópico, como: “ eu preciso ir" e respectivo aceite;

2) uma troca final de elementos de encerramento, por exemplo: "tchau", "até logo", "a gente se vê depois então" ou equivalentes.

Os não obrigatórios são:

1) encerramento de um tópico, tipicamente um tópico implicativo de fechamento, como, por exemplo, planejar/citar encontros futuros, retomar o primeiro tópico discutido na interação, mandar abraços para a familiares, etc.;

2) uso de componentes de tipificação da interação, quando apropriado, tais como: "obrigado/a", "muito obrigado/a" e "de nada" ou equivalentes.

A descrição de Schegloff e Sacks (1974) corresponde a um modelo de encerramento clássico das interações cotidianas/mundanas, que tende a ser mais elaborado do que nas interações institucionais. Estas costumam ter suas particularidades por estarem voltadas para o cumprimento de seu mandato institucional. Dessa maneira, suas sequências de fechamento tendem a estar relacionadas com o tipo de serviço que as instituições fornecem e, às vezes, com posicionamentos dos/as profissionais de cada estabelecimento (Ostermann, 2000a, 2000b).

O estudo de Ostermann (2002) também corrobora essas afirmações, ao nos mostrar, por meio de seus dados, que o tipo de serviço fornecido pela Delegacia da Mulher às vítimas, no primeiro contato, é o boletim de ocorrência, o que parece

\footnotetext{
50 "a conversation that ends a state of talk" (p.111). Por exemplo, um telefonema, um encontro de amigos, não valendo para, por exemplo, os membros de uma família em sua sala de estar, funcionários que estejam compartilhando um escritório, passageiros juntos em um meio de transporte, etc.

${ }^{51} \mathrm{O}$ pré-encerramento deixa de ser 'pré-' se aceito, pois a aceitação estabelece o mandado de realizar o fechamento da conversa naquele momento.
} 
dispensar a necessidade de um fechamento mais elaborado ou, como ela nos mostrou, fechamento algum. Em contrapartida, o Centro Feminista de Intervenção na Violência contra a mulher, analisado por ela, proporciona, no primeiro atendimento, o início de um relacionamento com a vítima e produz um documento interno, espécie de ficha, cujo objetivo é informar as outras profissionais no estabelecimento (advogadas e psicólogas) sobre o histórico da vítima e a razão pela qual ela procurou o Centro. As suas sequências de fechamento, por sua vez, são desenvolvidas em sua integridade, mais elaboradas, negociadas e com frequentes movimentos de abandono da sequência de fechamento até que o encerramento do encontro seja mutuamente realizado. Ambas as instituições analisadas estão localizadas em cidades da região Sudeste do Brasil.

Baldock e Prior (1981 apud Ostermann, 2002) comparam sua análise de entrevistas entre assistentes sociais e clientes com os resultados da pesquisa de Byrne e Long (1976), que demonstram que a classe dos/as médicos/as parece não apresentar dificuldade em fechar interações com pacientes, por conta de sua pista contextual típica do fechamento de uma consulta: a ação de destacar a prescrição médica do bloco impresso, fazendo com que os pacientes tendam a responder a essa ação praticamente de maneira condicionada. Baldock e Prior (1981) demonstram que as interações com assistentes sociais têm uma estrutura bem mais flexível quando comparadas a essa estrutura de interações médicos/as-pacientes. Nas interações assistentes sociais-clientes, os/as profissionais apresentam muito mais dificuldade em fechar seus encontros e, em consequência, os fechamentos daquele tipo de interação tendem a ser mais negociados e elaborados.

Monteiro (2011) também apresenta como se dá a organização de interações de atendimentos de ação social, em geral feitos por técnicos, que podem ser assistentes sociais ou psicólogos, e seus/suas atendidos/as são chamados de utentes $^{52}$, em português de Portugal. $\mathrm{O}$ autor afirma que o fechamento é a etapa mais ritualizada do atendimento, em que ocorre uma reorganização do espaço onde o atendimento teve lugar: há uma troca das últimas informações e são arrumados documentos e pertences. Tais ações são seguidas de cumprimentos e, no caso dos

\footnotetext{
${ }^{52}$ No Brasil os/as utentes são chamados de usuários/as pelos setores de assistência social do Estado e de assistidos/as pelas ONGs e pela Defensoria Pública. É o tipo de interação que poderia ser classificada dentro da categoria de interagentes profissionais-clientes.
} 
atendimentos realizados em gabinete, o utente sai desse espaço. Em resumo, no encerramento prototípico dos dados analisados por ele, há as seguintes tarefas/ações: a profissional chama a pessoa atendida pelo nome e usa elementos de pré-fechamento (por exemplo, “vamos então ficar por aqui?”), que são aceitos pela utente "vamos ficar por aqui doutora"; em seguida, a técnica faz referência à sua disponibilidade futura, passando à fase de recapitulação das ações a serem realizadas e referência ao próximo encontro.

As abordagens sociais da TSN como interações de "trabalho" têm como interagentes voluntários/as e assistidos/as e têm como objetivo a criação de uma relação com essas pessoas atendidas, de forma que, se houver algo que possa ser feito pela ONG para sua reinserção social, seja feito, bem como a criação de um ambiente de escuta para aqueles/as que, muitas vezes, não têm com quem compartilhar seus problemas e precisam apenas ser ouvidos/as. Assim, são semelhantes às interações entre profissional-cliente, já que a equipe possui um mandato institucional, porém também às conversas cotidianas, devido à tentativa de construção de vínculos. Essas similaridades são marcadas interacionalmente, como mostraremos nesta seção.

É importante destacar que, salvo raras exceções, que geralmente ocorrem em atendimentos a mais de uma pessoa ao mesmo tempo, o/a voluntário/a é quem inicia o fechamento. Esse pode ser um fenômeno decorrente da limitação de tempo dos atendimentos aos/às assistidos/as e de ser a pessoa responsável por conduzir a interação visando seu mandato institucional. A limitação de tempo se dá porque o transporte dos voluntários da TSN tem pontos específicos a percorrer e cada membro da equipe de abordagem costuma conversar com mais de uma pessoa, nesses pontos do percurso. Isso faz com que os atendimentos, mesmo quando prolongados, acabem tendo um tempo limitado. É comum a equipe do alimento finalizar o seu trabalho de distribuição dos itens alimentícios e ficar aguardando o social acabar seus atendimentos. Com isso, mesmo que haja alguma condução propositiva/oferta em curso, em algum momento, será preciso encerrar a interação e fazer uma recapitulação das ações a serem feitas. Outro fator que evidencia que o fechamento dessas interações parece mais delicado do que ocorre, de modo geral, nas conversas cotidianas, é o fato de que os/as assistidos/as não têm muitas oportunidades de serem ouvidos. Logo, é preciso ter cuidado para que o/a 
assistido/a não se sinta "invisível", sem a atenção merecida, caso ainda tenha coisas que considere relevantes a serem ditas.

Dessa forma, uma das primeiras constatações é de que o tamanho do fechamento da abordagem pode variar bastante, podendo ser pequeno, nas situações em que se trata de um reencontro ou conversa sem que haja uma demanda específica, ou maiores, com movimentos de suspensão do fechamento até o fecho, de fato. Tanto nos casos de fechamentos em que haja demanda específica quanto naqueles de manutenção de vínculo, eles são iniciados com elementos de préfechamento. Mas, como nos mostra Schegloff e Sacks (1974), o pré-fechamento, além de ser um convite ao encerramento, pode realizar diferentes ações.

Nos casos de abordagens sociais que visam apenas à manutenção do vínculo com os/as assistidos/as, seria mais um encerramento preocupado com isso, somente, de manutenção de vínculos, visto que não há nada de imediato a ser feito. Logo, antes do fechamento, pode haver a ação de verificação de necessidade de algo que costuma ser entregue pela equipe do social, por meio de pares de perguntasrespostas, seguido de pares de elementos de fechamento e componentes de tipificação da interação, como pode ser observado no excerto 17, da interação entre as voluntárias Meire e Laura e a assistida Alice com o assistido João:

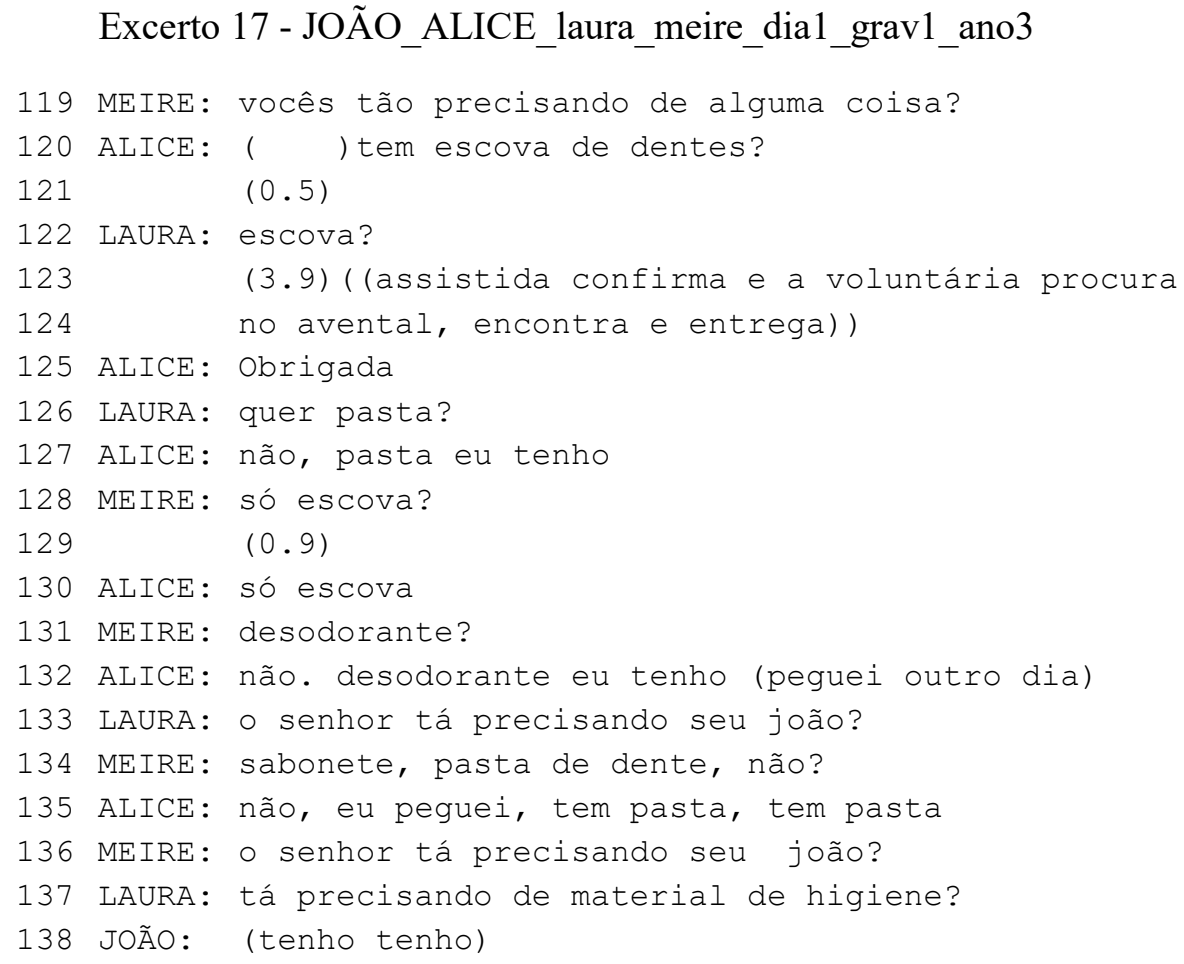




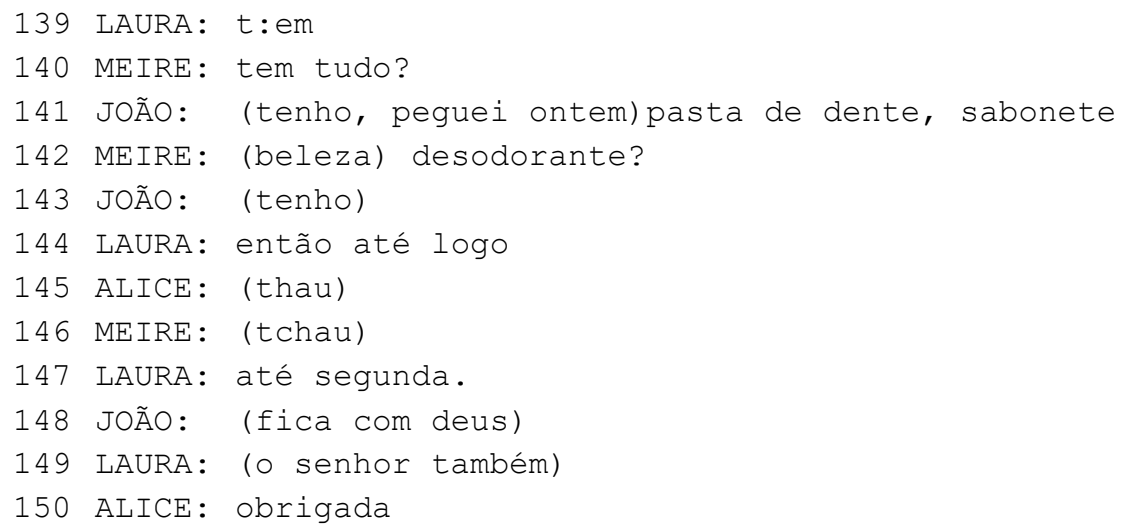

Quando se trata de assistidos/as que já são acompanhados/as e não há nenhuma demanda ou ajuste novo, costuma ocorrer essa verificação de necessidade de itens de básicos, que pode ser feita de forma resumida, apenas com uma verificação mais ampla (1.119) seguida de entrega dos itens de necessidade que a equipe possa oferecer, ou de maneira detalhada, no formato lista, com uma sequência de oferta-aceite/recusa de produtos disponíveis para serem entregues às pessoas atendidas (1.119-143), seguida de elementos de fechamento (1.144-150). Apesar do detalhamento dos itens e da repetição de ofertas, por se tratar de 2 pessoas atendidas, podemos notar que se trata de um encerramento breve, característico dessa abordagem mais simples, em que, após uma conversa, verifica-se se há necessidades não atendidas antes de finalizar a abordagem. Dessa forma, no excerto apresentado, o fechamento é iniciado pela voluntária Laura, por meio do "então até logo" (1.144), seguido da referência ao próximo dia de encontro com a TSN, segunda-feira (1.147), e aceitos pelos seus interagentes que responderam com diferentes elementos (implicativos) de encerramento $(1.145,146,148)$ e de agradecimento por parte de uma das pessoas atendidas (1.150).

Algumas vezes, porém, quando todos estão à espera da equipe de abordagem finalizar os atendimentos e não tem nenhum tópico delicado em curso, é preciso fornecer um account sobre a necessidade de encerramento da interação, projetando o próximo encontro, para demonstrar que aquela conversa poderá ter uma continuidade, como no fragmento a seguir de encerramento da conversa entre a voluntária Merida e a assistida Alice. 


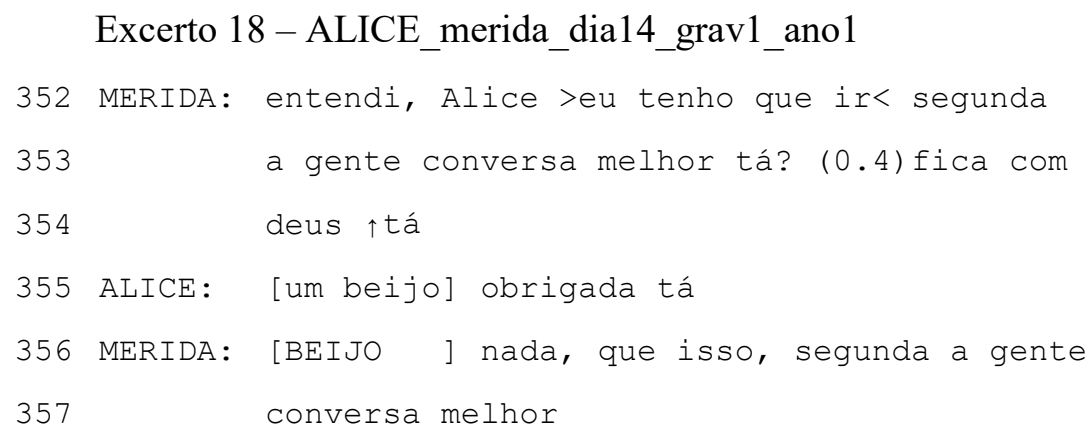

O encerramento apresentado é ainda menor, mas também possui os elementos descritos por Schegloffe Sacks (1974): pré-fechamento por meio do account de que a voluntária precisa ir embora, como forma de mitigar a ação de encerramento (">eu tenho que ir<" 1.352), seguido de troca de elementos de fechamento (1.353-356). Embora esse fechamento se mostre apressado na fala da voluntária, pois fazia alguns minutos que todos a estavam aguardando, ela repete, por duas vezes, a disponibilidade futura de dar prosseguimento à conversa na qual estavam engajadas, fazendo referência ao próximo dia de entrega da TSN (352-353, 356357), na tentativa de manutenção do vínculo.

Por sua vez, nas interações em que há qualquer tipo de marcação ou acordo com o/a assistido/a, há uma recapitulação das ações a serem realizadas, como pode ser visto a seguir, no qual o assistido Hugo é atendido por Merida e Léo, em uma abordagem de formalização de ajustes para retorno à terra natal.

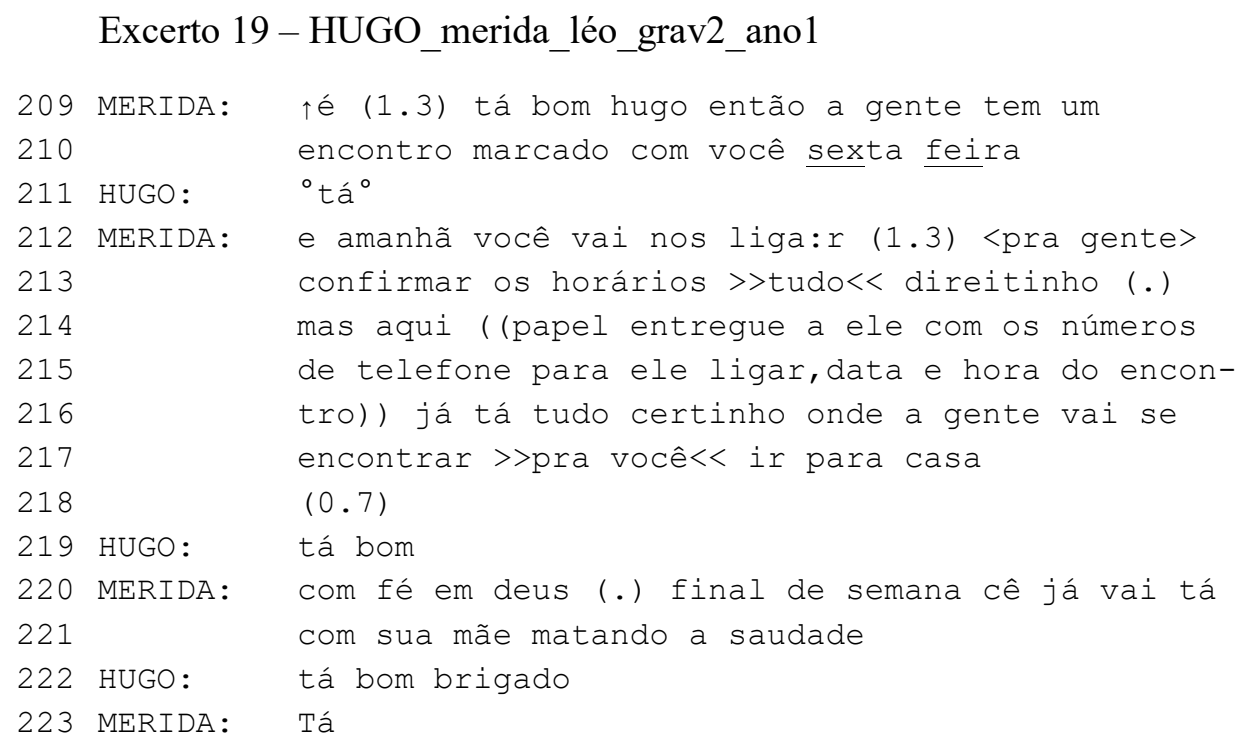




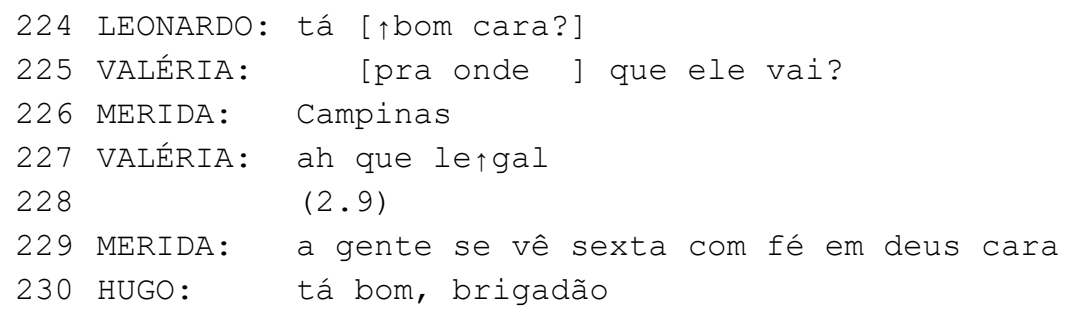

O excerto apresentado mostra que, ao fazer o fechamento da abordagem ao Hugo, Merida retoma os ajustes da marcação de encontro, introduzidos pelo préfechamento "tá bom hugo então" (1.209) e seguido do resumo do acerto (1.210, 212-214), que é aceito por Hugo com marcadores de recebimento (1. 211, 219). Vemos que há um tópico implicativo de fechamento pela formulação das informações acertadas, com expressões típicas de fechamento e das ações futuras (1.220-221), aceito com agradecimento pelo assistido (1. 222), repetido (1.230) após o elemento de fechamento usado pela voluntária, ao se despedir (1.229).

No decorrer desta pesquisa, houve uma mudança nos procedimentos de fechamento envolvendo arranjos de ações futuras do/a assistido/a, já como uma das contribuições da tese: em vez de serem repetidos os pontos do arranjo, passou-se a checar o entendimento do/a assistido/a por meio de perguntas, que têm como função um pedido de um resumo do que foi combinado. Após a checagem de entendimento, pode haver suspensão temporária do encerramento, para deixar claros os ajustes e, só depois de prolongamentos da conversa, haver a retomada do fechamento, como pode ser visto no excerto da interação entre as voluntárias Meire e Merida e o assistido Cláudio.

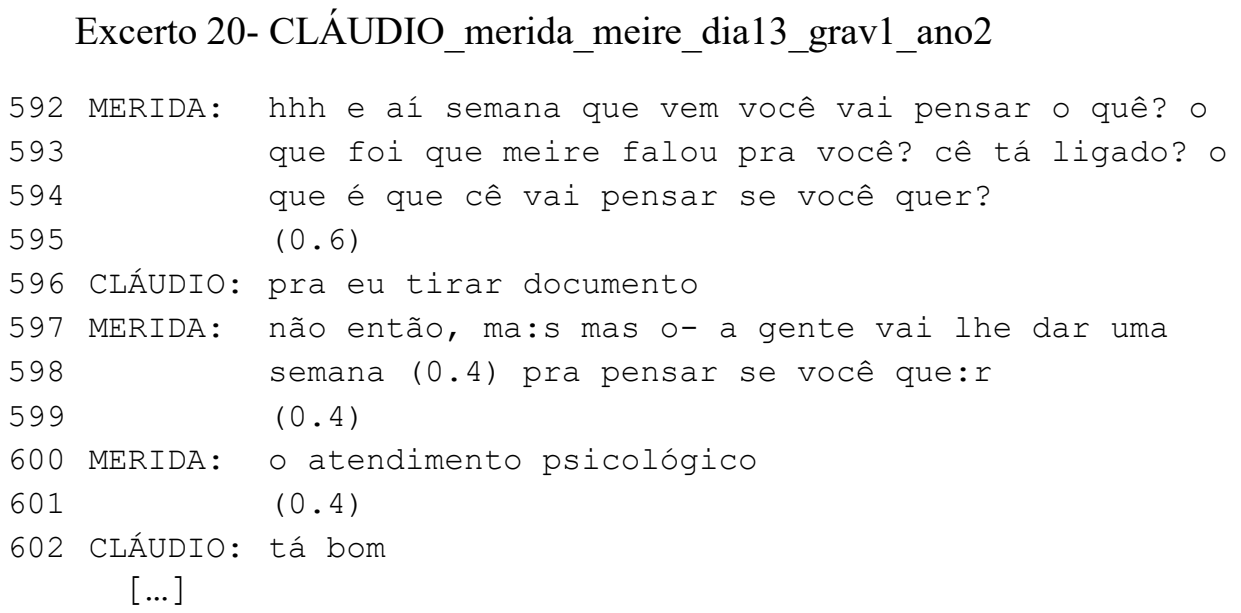




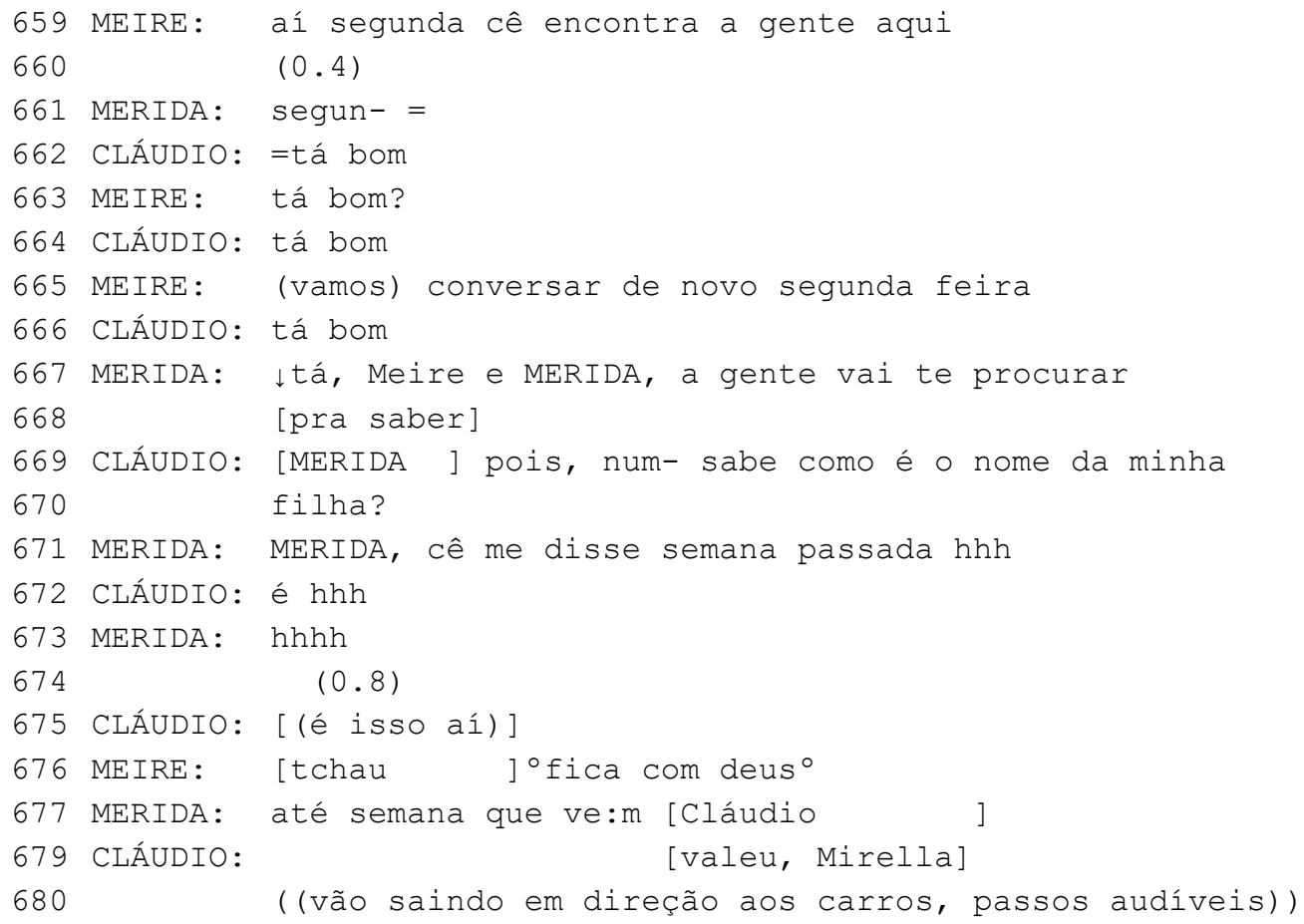

O excerto apresentado é um dos que mostram a importância da checagem de informações sobre arranjos futuros, no encerramento, quando se acerta algo com os/as assistidos/as. Isto porque, muitas vezes, surgem vários assuntos em uma única abordagem, o que pode causar alguma confusão para os assistidos e gerar problemas de intersubjetividade (Heritage, 1984) quanto aos arranjos ou orientações para ações futuras. Tanto que, após Merida solicitar ao Cláudio a informação do que foi acertado (1.592-594), ele responde com uma das questões abordadas na interação, mas que não teria relação com a proposta de pensar por uma semana (“pra eu tirar documento", 1.596). Diante do entendimento apresentado pelo assistido, tornou-se possível fazer um reparo relembrando a proposta, antes de finalizar a conversa $(1.597-598,600)$, o qual é aceito por ele (1.602). Depois disso, há uma suspensão da seção de fechamento nas linhas omitidas no excerto (1.603-658), em que o/as interagentes falam sobre o atendimento psicológico, sobre o local de retirada de documentos e ouve-se a movimentação de voluntários e a convocação para que retornem ao encerramento, por parte da fala de uma das voluntárias em volume mais alto "VAMOS LÁ GENTE? PARTIU ((chamando para irem embora)". O tópico implicativo de fechamento é o reforço do reencontro para a semana 
seguinte (1.659), mediante vários pares de pré-fechamento (1.62-667), que levam aos elementos de fechamento (1.676-679).

Da mesma maneira que o tamanho do encerramento pode variar bastante, a sua suspensão também pode, pois, ainda que haja a pressa do tempo limitado em cada ponto de parada, há sempre a preocupação com a manutenção da relação com a pessoa atendida, criação de vínculos e o registro da disponibilidade para continuarem a conversa na semana seguinte, o que leva, algumas vezes, a mais de um movimento de abandono do tópico de fechamento até que os/as interagentes consigam voltar ao encerramento. Nota-se, pois, que essa preocupação do estabelecimento de vínculos é um dos pontos centrais nos fechamentos das abordagens, juntamente com a retomada/checagem dos ajustes, em caso de conduções propositivas que tenham como fim algum tipo de acordo com os/as assistidos/as que envolva ações futuras.

Assim sendo, encontramos os elementos de fechamento de conversas cotidianas (Schegloff e Sacks, 1974), como também similaridade com interações institucionais que envolvem o serviço social (Baldock e Prior, 1981; Monteiro, 2011) ou o Centro Feminista de Intervenção na Violência contra a mulher (Ostermann, 2002), que possuem um fechamento mais elaborado, negociado e, consequentemente, mutuamente realizado pelos/as interagentes. A natureza do fechamento nesses contextos tem um ponto comum: o uso da conversa/abordagem para construção de algum tipo de vínculo, daí as similaridades com os estudos citados.

A checagem da compreensão do/a assistido/a em relação aos ajustes das ações futuras pode ser considerada o que a literatura da Análise da Conversa chama de pré-arranjos, embora não tenhamos encontrado exemplos desse tipo: o pedir ao/à outro/a o resumo do que foi arranjado. Logo se trata de um ponto novo.

Além disso, há um fator a mais: para quem costuma ser tratado como invisível, o fechamento abrupto pode ser interpretado como marca de insensibilidade, não à interação, mas ao/à próprio/a assistido/a. Por isso, a preocupação constante em reforçar a disponibilidade para continuação das conversas na semana seguinte.

Dessa forma, a delicadeza maior de fechamentos nesse contexto, é que por mais que cause estranhamento o corte abrupto em conversas cotidianas, sem 
nenhuma sensibilidade para o corte, não é comum que a pessoa se sinta invisível.

Isso impede a dispensa de um fechamento mais elaborado, pelo contexto da interação e pelos próprios objetivos da abordagem social. 


\section{Ofertas com estrutura preferida}

Como apresentado no capítulo 3, seção 3.2, a organização de preferência (Pomerantz, 1984; Pomerantz e Heritage, 2013; Shegloff, 2007) também pode ser observada em Primeiras Partes do Par. Neste capítulo, abordaremos as ofertas com estrutura preferida, no nosso corpus, que podem ser ilustradas ${ }^{53}$ mediante as gravações de abordagens que tiveram oferta de participação em um curso gerador de renda, de chocolates ${ }^{54}$, em 2016 , e um caso de oferta de cartão de visitas, ocorrida no início de 2017.

\section{1.}

\section{Ofertas de participação em curso de chocolates}

O curso de chocolates foi criado em 2016 e despertou muito interesse das assistidas em situação de vulnerabilidade social. Elas receberiam, após o curso, o material para suas primeiras produções, podendo conseguir lucro para comprar mais materiais, sem precisar ter o dinheiro do primeiro investimento. Para a escolha das gravações, obedecemos a uma ordem cronológica dessas ofertas, dentre as quais estão apenas 3 ofertas para participações da segunda edição do curso, que aconteceria na semana antecedente à Páscoa, e de 1 oferta para quando houvesse o curso, sem previsão exata de data. Essas ofertas foram feitas pela mesma voluntária, Merida, a assistidas diferentes. Seguem os fragmentos das respectivas ofertas:

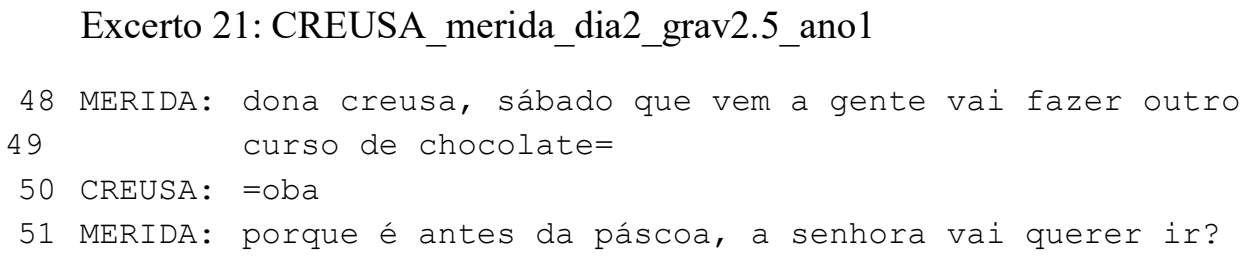

${ }^{53}$ Os tipos de ofertas de ajuda apresentados aqui são meramente ilustrativos, no sentido de que há outros tipos com formato preferido. Em trabalhos posteriores, poderemos aprofundar mais o estudo desse formato, conforme organizarmos outros grupos de diferentes tipos de oferta de ajuda presentes no corpus.

${ }^{54}$ Em 2017, ocorreram outros cursos na sede, mas não houve gravações das ofertas para que assistidos/as pudessem participar. Por isso, analisamos aqui apenas as ofertas para o curso de chocolates. 


\section{Excerto 22: ALICE_merida_dia2_grav2.4_ano1}

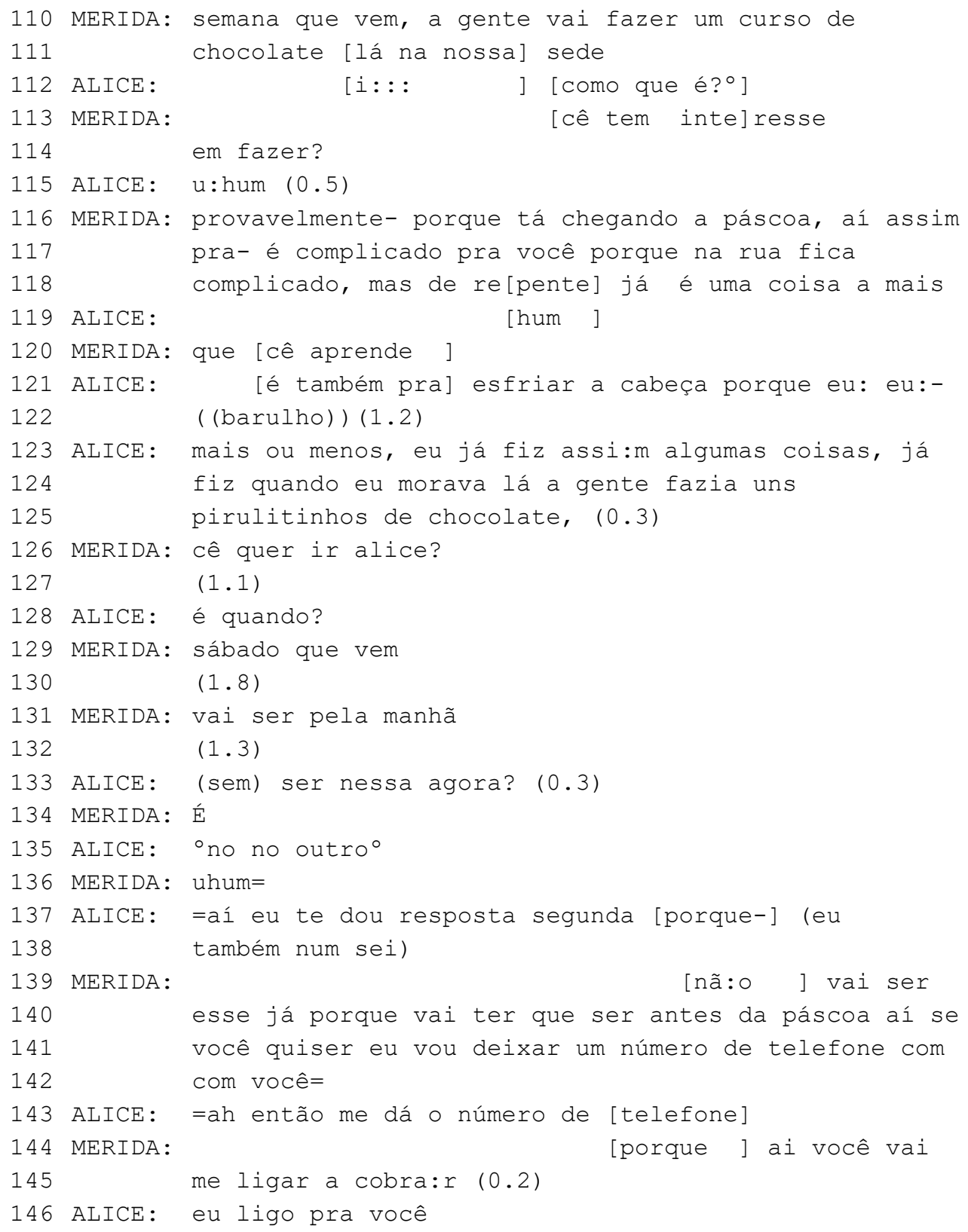

\section{Excerto 23: JULIA_merida_dia2_grav2.3_ano1}

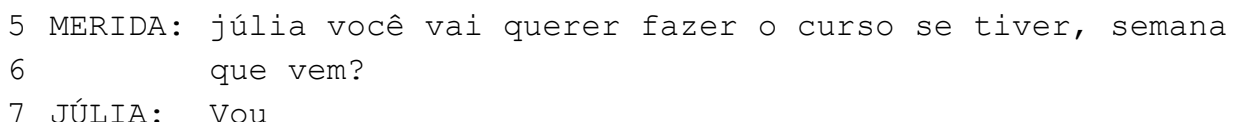

\section{Excerto 24: LUIZA_merida_dia18_grav1_ano1}




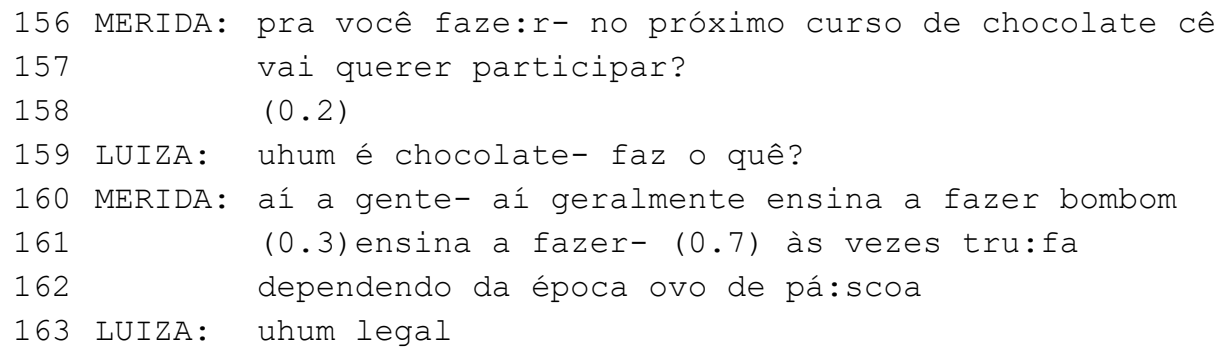

A primeira questão relevante a destacar é que as assistidas dos excertos 21 e 23 participaram da primeira edição do curso, tornando dispensáveis mais explicações acerca do mesmo ou dúvidas mediante sequências inseridas.

As assistidas Creusa e Alice tiveram uma pré-oferta ao serem informadas sobre o próximo curso, respectivamente nas linhas 48-49 e 110-111, dos excertos 21 e 22. Como resposta, forneceram o aceite, recorrendo a marcadores de recebimento entusiasmados, que já demonstravam interesse no curso: "=oba" (1.50) e "[i:::] [como que é $\left.{ }^{\circ}\right]$ " (1.112), o que possibilitou o desenvolvimento da oferta.

É interessante notar que o formato das ofertas acima é praticamente o mesmo, elas ocorrem pela verificação do desejo do outro, pois, embora a participação no curso seja entendida como um benefício pelos/as voluntários/as, a pessoa pode julgar se é do seu interesse ou não. Essa verificação da vontade do outro é feita por intermédio de uma oferta no formato preferido, direta, sem demora, sem pausas ou accounts, em um primeiro momento: "[cê tem inte]resse em fazer?" (1.113-114), no excerto 24, e do seguinte formato gramatical: nome e/ou forma de tratamento (você/cê/senhora) + verbo querer na terceira pessoa do presente (quer) ou do futuro do presente do indicativo (vai querer) + complemento verbal que faz referência ao curso de chocolates ou verbo ir, que retoma a ideia de ida ao curso. Isso pode ser constatado nas linhas 51 ("a senhora vai querer ir?") do excerto 21, na linha 5 ("você vai querer fazer o curso") do excerto 23, na repetição da oferta à Júlia, e nas linhas 156-157 (“cê vai querer participar?") do excerto 24. Assim sendo, em todas essas ofertas, as assistidas eram colocadas em uma posição de agente de um “querer", em que a voluntária propõe algo que possa ser desejado por elas: a participação no curso de chocolates, condicionando-as a fornecer uma resposta, preferencialmente, o aceite ou a recusa, em turno subsequente. Trata-se de um formato do tipo de oferta que Curl (2006) 
descreveu como participantes do grupo de ofertas geradas interacionalmente na conversa, do tipo: "Você quer (que eu) X?".

Praticamente todas as assistidas aceitaram de imediato, embora com respostas diferentes, com ação responsiva no formato preferido: a Creusa, além de responder de modo afirmativo "vou", incrementou o aceite com "claro" (1.51), a Júlia confirmou "vou", enquanto a Alice e a Luiza responderam com "u:hum" (1.115) "uhum" (1.159), que podem ser considerados aceites, com recibo fraco de concordância (Couper-Kuhlen, 2009; Gardner, 1997). Na situação da Luiza, como ainda não havia uma data certa para o curso, não houve repetição da oferta para confirmação de sua resposta ou recusa.

No caso da Alice, porém, o curso já tinha data e, por isso, a voluntária traz um account, antes de repetir a oferta, ao ressaltar o fato de ser complicado, já que ela está em situação de rua $(1.117,119$ do excerto 22$)$ e provavelmente não teria como colocar em prática, de imediato, o que aprendesse no curso, mas a assistida minimiza a preocupação levantada pela voluntária $(1.121,123-125)$ ressaltando que é uma boa possibilidade para "esfriar a cabeça" e que já até fez pirulitos de chocolate, o que estimula a repetição: "cê quer ir alice?".

As próximas respostas de Alice, porém, vêm no formato despreferido, com atraso, sequências inseridas e incerteza do aceite ou recusa: depois de um LRT (1.127), em sua ação responsiva, Alice traz uma sequência inserida de perguntas e respostas com pedidos de informação sobre o curso (1.128-134), que leva a um problema de intersubjetividade (Heritage, 1984) quanto ao dia do curso e a informação de adiamento da confirmação do aceite ou recusa acompanhado de justificativa: "=aí eu te dou resposta segunda [porque-] (eu também num sei)" (1.137-138). Merida, por sua vez, faz um reparo informando que o curso já seria no sábado seguinte, dando a possibilidade de ela ligar, já que não poderia dar a resposta naquele momento, por meio da oferta na condicional: "se você quiser eu vou deixar um número de telefone com você=", entendida como aceita após o pedido: "=ah então me dá o número de [telefone]", por meio das instruções no imperativo: "[porque] ai você vai me ligar a cobrar", seguidas da confirmação de aceite "eu ligo pra você" (1.141-147) e da continuação de negociações sobre como fazer, que foram omitidas do excerto. Nas 
continuações das interações, omitidas em todos os fragmentos apresentados, houve ajustes sobre a execução do curso.

É válido dizer que, embora tenhamos apenas 4 registros desse tipo de oferta gravados, as notas de campo mostram que as respostas a esse tipo de oferta costumam ser aceites, ainda que, por algum motivo, a pessoa não compareça no dia. Nos casos em que há recusa, geralmente, é seguida de um account que justifica a impossibilidade de participação do/a destinatário/a da oferta e, nas poucas situações de adiamento de resposta, como no excerto 22 , a possibilidade de adiamento parte do/a assistido/a.

\section{2.}

\section{Oferta de cartões de visita-aceite}

Segue oferta de cartão de visitas ao assistido Alfredo, que teve a parte que o antecede reproduzida no excerto 12. Ele havia compartilhado, com as voluntárias participantes da interação, informações sobre sua profissão e sobre sua atual situação de desemprego.

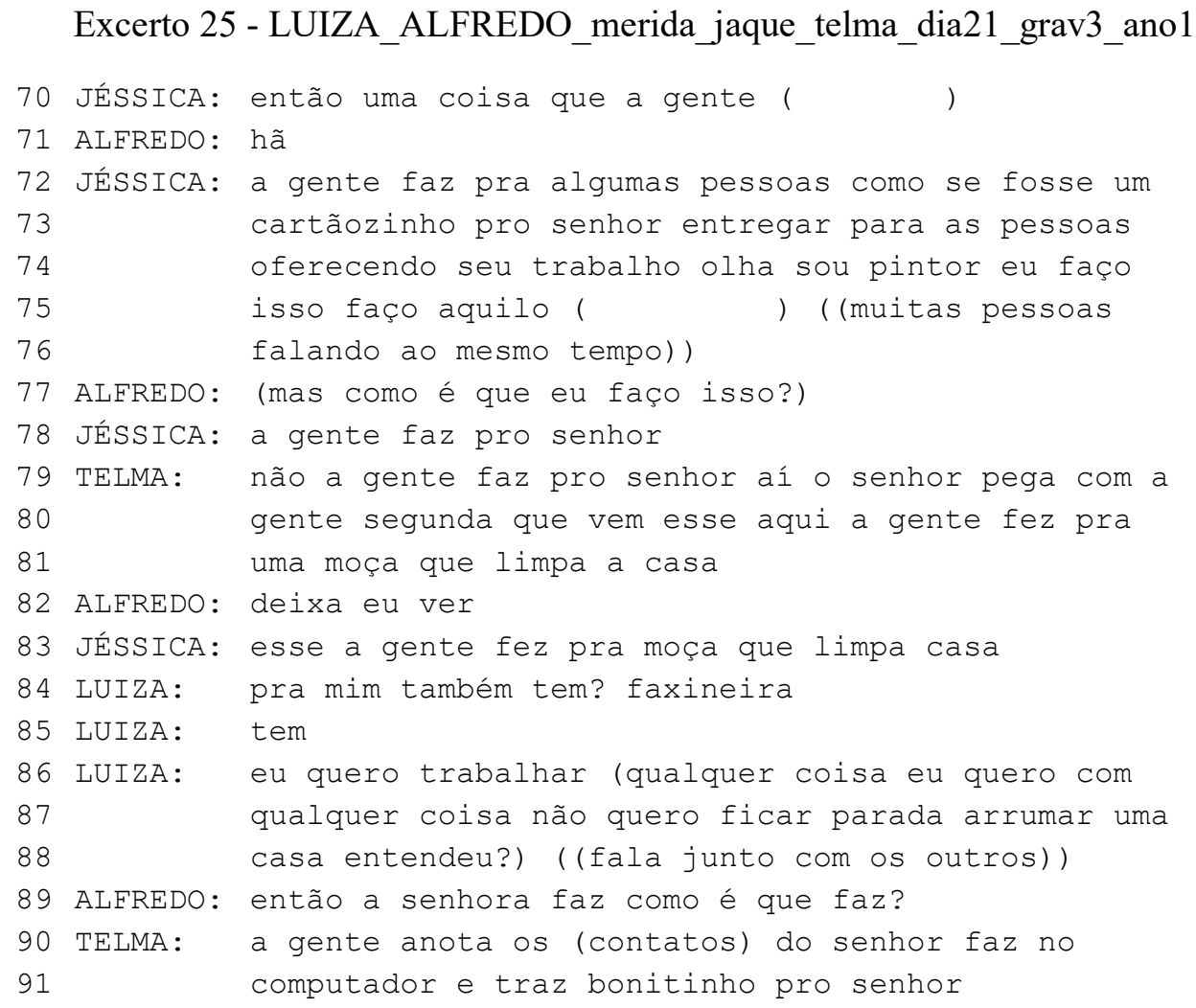


Concretizada a escuta por parte das voluntárias, Jéssica anuncia a disponibilidade de um serviço que pode ser oferecido ao Alfredo (1. 70,72-75), informando a ele o que elas fazem para algumas pessoas: cartõezinhos que também poderiam ser feitos para que ele possa distribuir e tentar conseguir algum trabalho. Esse anúncio pode ser interpretado como tendo a função de uma pré-oferta. A resposta do assistido demonstra interesse no serviço, por meio de um pedido de informação de como fazer "(mas como é que eu faço isso?)" (1.77). Jéssica, por sua vez, ao responder, formaliza a oferta de maneira direta, sem atrasos (1.78), que é complementada por Telma, que mostra um exemplo a ele (1.-79-81). Essa oferta, porém, possui formato declarativo “a gente faz pro senhor" (1.78), não possuindo entonação de pergunta, uma vez que a demonstração de interesse dele já havia sido feita mediante sua resposta anterior, facilitando, assim, o trabalho interacional das voluntárias que estavam dispostas a fazer os cartões profissionais para o senhor Alfredo. Então, após ele ver um modelo de cartão, finalmente confirma o aceite, por meio de uma paráfrase do que havia sido dito por ele mesmo e por elas: "então a senhora faz, como é que faz?" (1. 89) e de sua confirmação "tá bom tá bom” (1.96), após a solicitação ser respondida positivamente, com a descrição dos passos a serem dados (1.90-95). Na sequência dessa interação, os/as interagentes passaram aos ajustes e às anotações das informações do assistido, para que os cartões de visita fossem providenciados.

Nota-se, pois, por meio da oferta apresentada, que não há manifestações de resistência. Quando há algum recuo por parte do/a voluntário/a nesse tipo de oferta, é por conta de algum impasse para a sua execução, por exemplo, em caso de a pessoa não ter número de telefone para colocar em cartões profissionais, etc. Em situações assim, o interesse por parte do/a assistido/a não seria suficiente para que o cartão pudesse ser feito, mas, caso a equipe de abordagem julgue pertinente, pode oferecer o empréstimo de celular para que a pessoa tenha como receber ligações que viabilizem conseguir trabalhos (in)formais. Segue um fragmento em que, na abordagem de Merida à Luiza, constata-se a impossibilidade de fazer cartões para 
ela, por conta da ausência de um número para contato. Essa parte do excerto ocorreu depois de uma sondagem em que Luiza disse que gostaria de trabalhar com qualquer coisa, "até varrer uma rua".

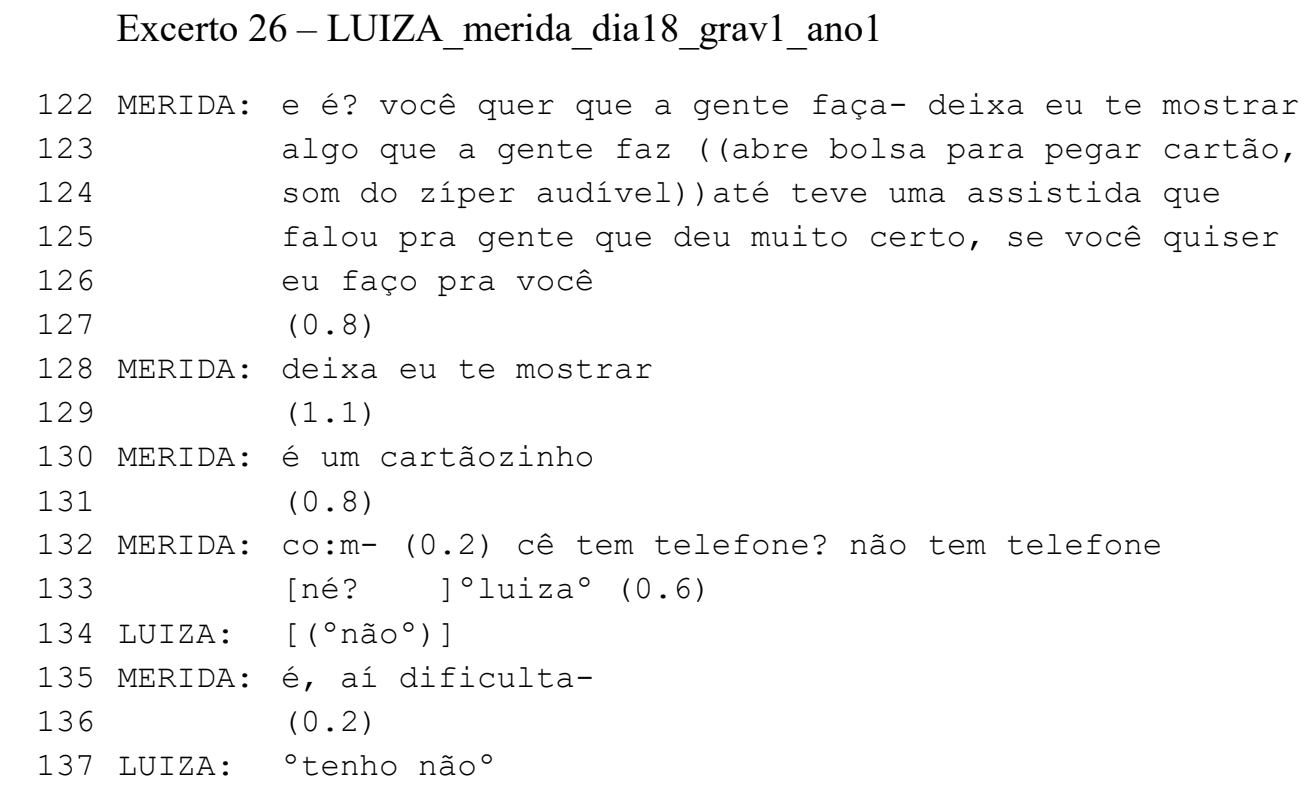

No excerto acima, vemos que a voluntária Merida oferece à assistida cartões produzidos pela TSN ("você quer que a gente faça-"1.122, "se você quiser eu faço pra você" 125-126), a princípio em um formato preferido, colocando a assistida como agente de um querer, por meio da verificação de interesse, tanto pelo formato "você quer" quanto pela condicional "se você quiser", já que ela ainda não havia demonstrado interesse nos cartões. Após a primeira oferta, ela se autointerrompe para mostrar modelos dos cartões, mas isso sem verificar, primeiro, a viabilidade: a assistida possuir algum telefone para contato, o que torna a oferta inadequada, até que ela tenha algum meio de contato para ser posto no cartão. As pausas entre os turnos $(1.27,129,131)$ ocorrem por conta da movimentação de abrir a bolsa para pegar o modelo de cartão para ser mostrado à assistida.

Pelo excerto, percebe-se o desapontamento da voluntária e da assistida por conta dessa impossibilidade, por meio das suas falas em volume de voz mais baixo $(1.133,135,137)$ e da elocução "é: aí dificulta-", que verbaliza a questão da dificuldade e faz uma pequena pausa. Na sequência, ela explica à Luiza do que se 
tratava e informa a necessidade de um aparelho celular para tal, não pegando as informações dela, no momento.

O desenvolver dessa oferta nos mostra que, quando o/a voluntário/a não tiver certeza se o/a assistido/a tem algum telefone para contato, seria mais eficiente verificar isso, antes de fazer a oferta. Dessa forma, caso queira e possa, poderá fazer a oferta do empréstimo do telefone junto à oferta de cartão, desfazendo a inviabilidade para execução da condução propositiva sem que possa gerar algum desconforto ao/à assistido/a por não poder usufruir da oferta recebida.

As ofertas apresentadas com formato preferido são mais simples, no sentido de serem benéficas ao outro, sem que seja necessária uma grande contrapartida do/a assistido/a para concretização da oferta de ajuda. Junto a essa, podem ser somados os oferecimentos de alimento ou itens de higiene, feitos pela equipe de abordagem como meio de aproximação/reforço do vínculo. Consequentemente, as ações responsivas também são mais simples e não demandam muito esforço interacional por parte do/a assistido/a, cabendo um aceite ou uma recusa, que pode ter alguma justificativa apenas por uma questão de polidez. 


\section{8}

\section{Oferta com estrutura despreferida: atendimento psicológico}

Nesta pesquisa, também encontramos a estrutura despreferida na realização de determinadas ofertas, que será apresentada nesse capítulo. Para isso, apresentamos as ofertas de atendimento psicológico ${ }^{55}$, que ilustram esse fenômeno. O estudo de Oliveira (1999) também identificou a ocorrência desse fenômeno em relação à realização de pedidos.

Apesar dos benefícios projetados pela oferta, o que se observou, quanto à segunda parte do par, foi o aceite, a resistência com o adiamento do aceite ou recusa, e a recusa, propriamente dita. Essa variação de respostas à oferta aponta para algumas especificidades dessa ação. Uma delas diz respeito às diferentes interpretações do que está sendo oferecido. Pode parecer que o comportamento de moradores em situação de rua ou vulnerabilidade social já não é sensível ao padrão normativo da sociedade. Mas questões de autorrespeito revelam que crenças de senso comum sobre comportamento ainda orientam suas escolhas.

O modo como a equipe de abordagem social realiza as ofertas de atendimento psicológico revela uma orientação para a delicadeza da ação e do tópico. O conceito de delicadeza, na fala-em-interação, tem sido tratado na literatura especialmente com relação ao tópico. Ostermann e Rosa (2012), ao analisarem consultas ginecológicas e obstétricas, verificam que, nesses momentos delicados, há mudanças na orientação dos participantes - também chamadas de perturbações -, marcadas por hesitação, atrasos na produção de fala e/ou evitação de uso de alguns termos.

Bergmann (1998), por sua vez, faz uma distinção entre tópicos delicados (por exemplo, sexualidade, morte, aborto, etc.) e ações delicadas (como acusação,

\footnotetext{
$55 \mathrm{O}$ atendimento psicológico faz parte do Programa de Atendimento Psicossocial, que foi implementado em 2016, sugerido a partir da análise de uma das interações que constituem o corpus desta tese. Em uma das abordagens sociais, uma assistida afirmou ter casa e condições financeiras para sair da rua. Mas, no desenvolvimento da conversa, informou que não tinha vontade de voltar para casa por conta de um luto vivido pela morte do irmão. A partir daquele acontecimento, contounos que ela passara a desejar ficar longe da casa, bem como a se entregar ao álcool e a outras drogas. Ali ficou claro que um dos serviços que poderiam contribuir para a reinserção social de alguns assistidos era o oferecimento de atendimento psicológico. Como havia duas psicólogas no grupo, houve a implantação do referido Programa.
} 
pedido de desculpas, reclamações, insultos, etc.). O autor (1998) identifica também alguns traços que expressam mitigação das falas, como o riso, gestos, de expressões prosódicas ou expressões faciais, etc.

No caso da oferta de ajuda, foco deste capítulo, ela se diferencia das ações citadas por Bergmann (1998), na medida em aquelas se diferenciam dos exemplos de ações delicadas citadas pelo autor por envolverem custo ou dano para o falante ou para ouvinte. Já as ofertas, diferente também dos pedidos, representam tentativas de que o outro usufrua de uma ação futura que lhe é benéfica.

Se a ação, por si só, não é um exemplo típico de delicadeza, o problema pode estar no tópico, isto é, no que está sendo oferecido. O que define um tópico delicado é o modo como uma cultura associa a determinados tópicos significados que podem trazer consequências interacionais não desejadas ou aceitas. Nesse sentido, tópicos como sexo e aborto podem ser mais vistos como tabus em sociedades conservadoras, mas não em liberais.

$\mathrm{Na}$ sociedade brasileira, por exemplo, ainda se observa, no caso de atendimento psicológico, uma estigmatização daquele/a que procura o serviço. Nesse sentido, entendemos que não apenas o tópico, mas também a ação pode ser delicada. Se alguém oferece a outrem atendimento psicológico, pode ser porque essa pessoa julga a outra, no mínimo, como necessitada de ajuda para enfrentar a vida. Logo, essa pessoa pode ser considerada, ao menos, fraca. Assim como a oferta é delicada, o tópico o é também, pois predomina, no senso comum, o significado de que quem procura atendimento psicológico está doente ou até é maluco. Portanto, nesta pesquisa, optamos por considerar delicado o conjunto, daqui para frente como um tipo de oferta delicada.

Dado que a percepção de delicadeza desse tipo de oferta é subjetiva, o modo como os dados demonstram essa subjetividade está nas possibilidades de ações responsivas à oferta.

Para demonstrar essa variação de percepção, propomos melhor entender como os participantes se orientam para a delicadeza desse tipo de oferta. Para isso, examinamos, em 8.1., o par Anúncio-de-Oferta-Aceite; em 8.2., o par OfertaAceite; em 8.3., Oferta-Resistência, que leva ao adiamento da segunda parte do par; em 8.4., por fim, retomada da oferta dos casos de adiamento da SPP. 


\section{1.}

\section{Anúncio da oferta de atendimento psicológico-aceite}

A decisão de implantação do Programa de Atendimento Psicossocial, ainda sem data exata para começar, levou algumas voluntárias a anunciaram a novidade para alguns assistidos/as, os/as quais elas inferiram que poderiam ter interesse. De um modo geral, esses anúncios foram bem aceitos, ou porque o/a assistido/a reconhecia o potencial daquele serviço ou porque entendiam que a ONG estava sempre buscando forma de ajudar a quem está na rua.

No excerto seguinte, apresentaremos uma conversa entre as voluntárias Merida e Jaque com o assistido Júlio:

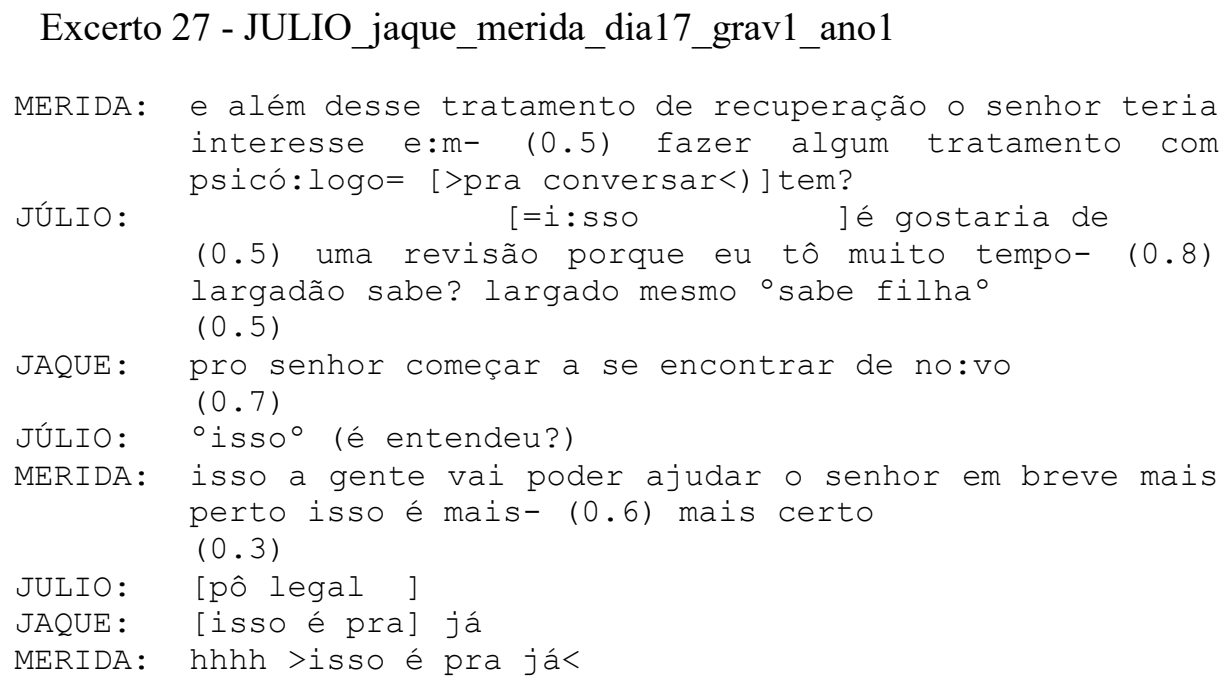

Primeiro, é importante dizer que a oferta só é embalada como anúncio nas linhas 29-30; antes disso, poderíamos dizer que se trata de uma oferta semelhante às demais. Então, é assim que nos referimos a essa ação inicial. Mesmo assim, nomeamos esta seção de anúncio da oferta, por se tratar do anúncio de um serviço que ainda não estava disponível.

$\mathrm{Na}$ oferta do atendimento psicológico ("o senhor teria interesse e:m(0.5) fazer algum tratamento com psicó:logo=", 1.19-21), é possível notar que há marcas de despreferência na primeira parte do par, por meio de hesitação, alongamentos e pausa da voluntária Merida, que revelam orientação para a delicadeza desse tipo de oferta. Essa orientação se manifesta também no reparo 
produzido pela voluntária com uma nova formulação (Heritage e Watson, 1979) “[ ( >pra conversar<) ]" para oferta de tratamento, termo usado geralmente em contextos de doenças/problemas de saúde. Com o reparo, a voluntária traduz o tratamento como a prática de conversar, uma prática coloquial que não é marcada pelo traço doença. Esses recursos estariam sendo usados para gerenciar a delicadeza do tópico e da ação (tipo de oferta).

A segunda parte do par, por sua vez, parece indicar aceite, já que o assistido responde com uma confirmação de interesse "[=i:sso ]" (1.22). Logo em seguida, formula de modo explícito seu interesse, usando o futuro do pretérito "gostaria" $(1.22)$.

Apesar de a primeira parte de sua ação responsiva ter sido dada sem demora, em fala colada e sobreposta à da voluntária, observam-se, na complementação da fala, perturbações que podem revelar orientação para uma ação delicada, por meio de pausas, alongamentos, diferença no volume de voz e a não-repetição dos termos "tratamento" ou "psicológico", ao parafrasear o serviço oferecido por Merida como "revisão" (1.22-24). A escolha do item lexical "revisão" aponta também para uma outra interpretação, esclarecida em outro momento da interação. $\mathrm{O}$ assistido já passara por um atendimento semelhante, o que talvez justifique seu aceite sem resistência, além dos accounts oferecidos.

A voluntária Jaque retoma o account do assistido e o sentido de revisão, para fazer uma formulação mais atenuada "pro senhor começar a se encontrar de no:vo" (1.26). O que é novamente aceito por Julio (“० isso ${ }^{\circ}, 1.28$ ).

Só na linha 29, é realizado o anúncio do tipo de oferta propriamente dito e, mais uma vez, formulado de modo atenuado: "a gente vai poder ajudar o senhor em breve mais perto isso é mais- (0.6) mais certo", (1.29-30). Em resposta, o assistido fornece uma avaliação positiva "[pô legal]" (1.32), mostrando, assim, sua predisposição ao aceite do serviço.

Apesar de o excerto apresentado ilustrar apenas o anúncio da oferta de atendimento psicológico, que, mesmo em caso de aceite, não passaria à fase de ajustes de marcação, as voluntárias já apresentam uma orientação para o desenvolvimento de uma ação do tipo delicada, ao produzirem formulações atenuadoras sobre a oferta e uma fala com pausas, hesitações e alongamentos. $\mathrm{O}$ assistido, por sua vez, também corresponde a essa orientação ao produzir uma fala 
com perturbações semelhantes, embora forneça a primeira resposta sem atrasos. Depois de o serviço de atendimento psicossocial ser empreendido, essa orientação fica ainda mais evidente, como poderemos constatar nas próximas seções.

\section{2.}

\section{O par Oferta-Aceite}

A análise do corpus evidencia que o oferecimento de atendimento psicológico é sempre realizado por uma estrutura despreferida. Já com relação aos/às assistidos/as, a organização de preferência varia de acordo com a ação responsiva. No caso do aceite, ele pode ter uma estrutura direta ou ser alcançado após ter alguma resistência revertida.

$\mathrm{O}$ excerto 28 ilustra um caso de aceite. O encontro com a assistida para oferecer o serviço de atendimento psicológico foi marcado previamente, dado que a mãe dela havia relatado às voluntárias sua preocupação com a depressão da filha. Foi planejada, então, uma conversa com a assistida, o que, à exceção de todos os outros encontros do corpus, não se deu na rua, mas em uma sala de uma ONG parceira. Participaram dessa interação as voluntárias Laura e Merida, a assistida Lorena, e sua mãe, Letícia, presente na cena.

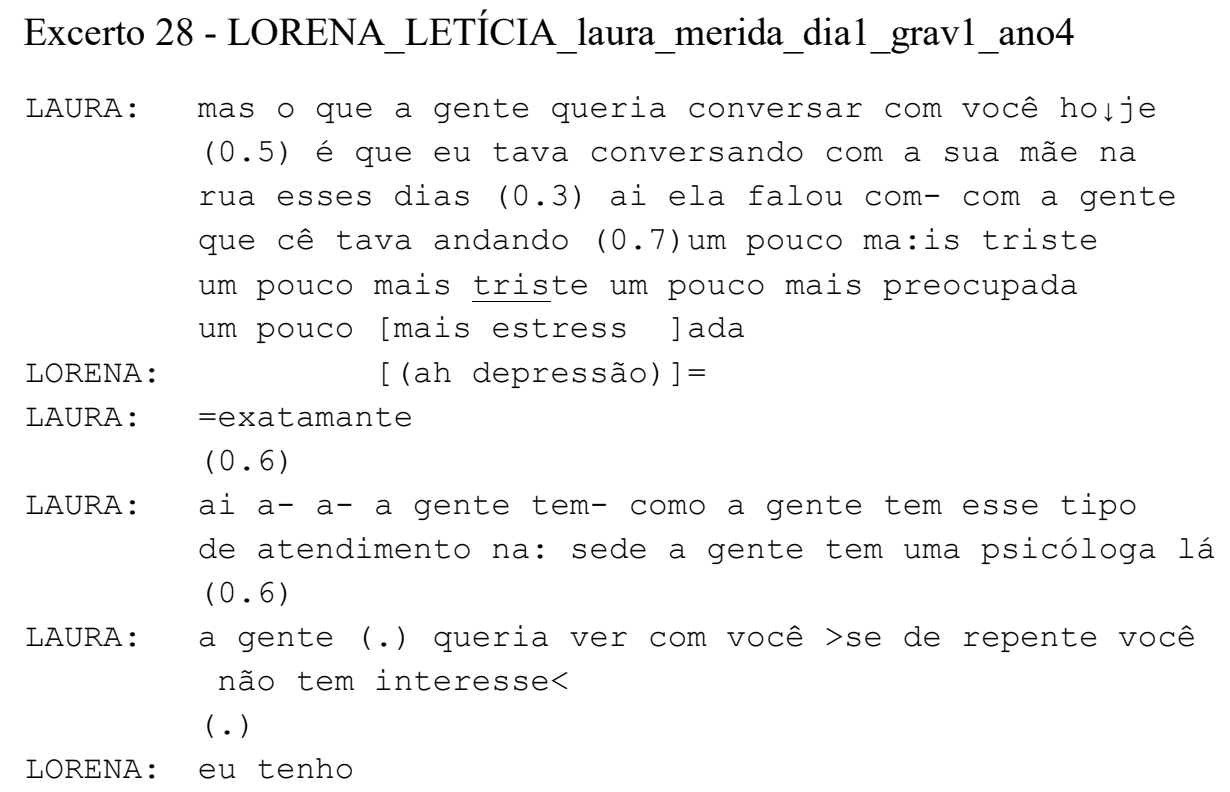


A conversa é iniciada com a exposição do motivo do encontro (1.1-6) que, por sua vez, justifica também a ação de oferecer atendimento psicológico. Mais uma vez, observa-se que a voluntária se orienta para a delicadeza do tópico depressão, modo como a mãe descreveu o estado da filha. O turno de Laura é marcado por pausas, hesitações e formulações que mostram o cuidado de evitar a palavra “depressão", recorrendo a um sintoma (tristeza) e a uma causa (estresse), ambas reconhecidas socialmente como normais, nos dias de hoje.

O gerenciamento da delicadeza na fala da voluntária é entendido pela assistida, que introduz um reparo, explicitando o que estava sendo tratado como um tabu “[ah depressão]=” (1.7), o que é imediatamente confirmado pela voluntária (“=exatamante", 1. 8).

Mesmo com o caminho aberto para a para a realização da oferta, a voluntária mantém a orientação para a delicadeza da oferta por meio de marcas de despreferência como perturbações de sua fala do tipo hesitação, repetição, fala acelerada e account (a ONG possui esse serviço) (1.11-12). Só depois dessa entrada e de mais um LRT, a voluntária faz a oferta por meio de uma checagem de interesse quase que indireta: "a gente (.) queria ver com você >se de repente se você não tem interesse<" (1.14-15), através de uma pergunta polar negativa, enquanto a assistida responde afirmativamente e diretamente: "eu tenho" (1.17).

Apesar de a literatura descrever aceites como ações de estrutura preferida, isso nem sempre acontece. O excerto 29 ilustra um caso de aceite com traços de despreferência. O ponto da conversa entre a voluntária Merida e o assistido Augusto se inicia após conversarem, entre outras coisas, sobre a dificuldade de conseguir trabalho. Merida, então, informa que a ONG poderia produzir cartões ou panfletos para divulgar os serviços que ele pode fazer, facilitando o seu retorno ao mercado de trabalho. Nesse tipo de suporte de propaganda, não há necessidade de incluir o endereço residencial da pessoa. Basta o nome, informações sobre o serviço e telefone para contato. É, nesse contexto, que Merida, juntamente com Santiago, introduz a oferta de atendimento psicológico:

\footnotetext{
Excerto 29 - AUGUSTO_merida_santiago_dia1_gra1.2_ano2

MERIDA: augusto (0.3) cê tem interesse e:m atendimento psicológico, não? conversar com um profissional da
} 


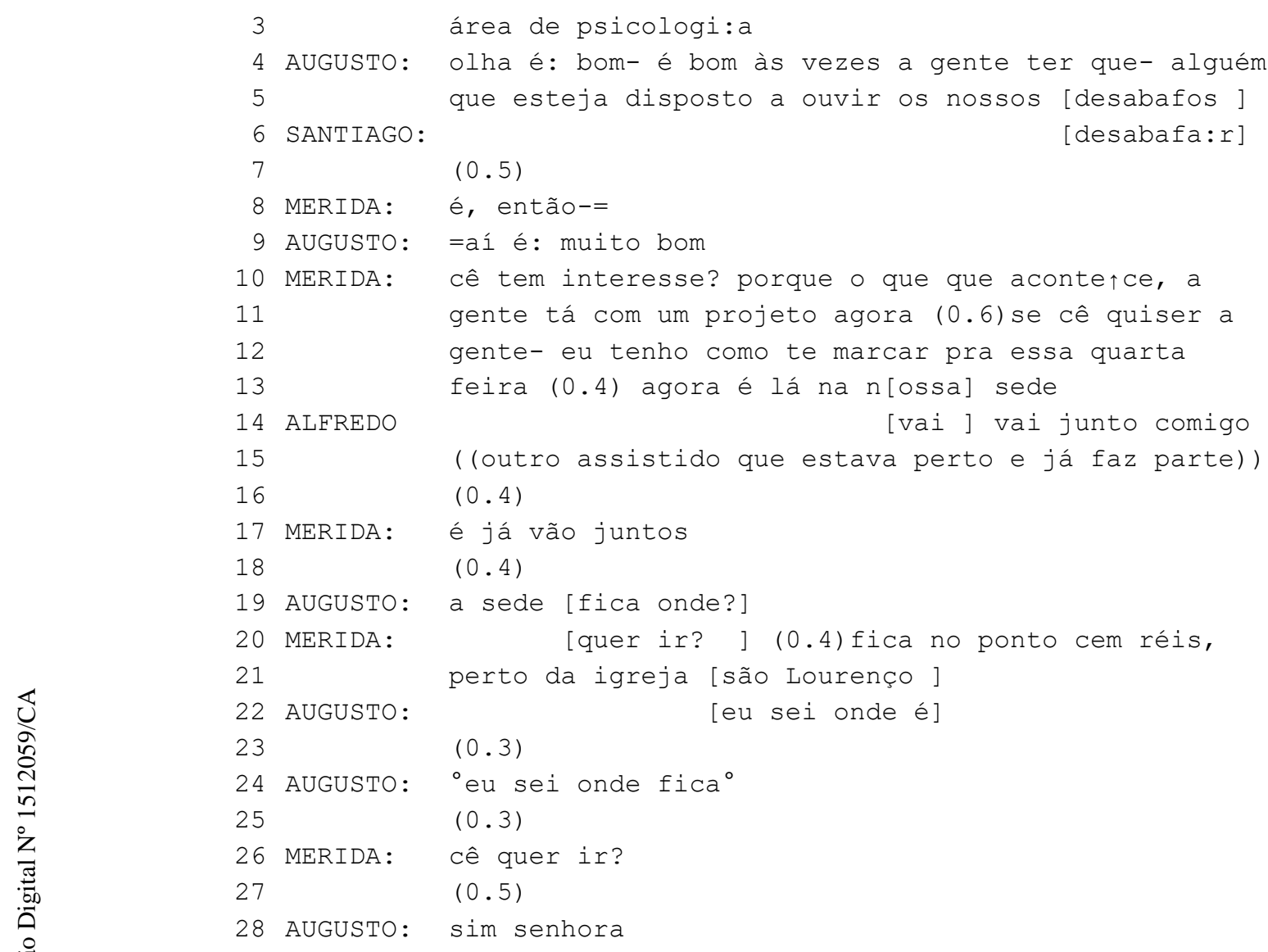

Mais uma vez se observa que a oferta é realizada por uma ação de checagem do interesse do assistido, o que é entendido também como uma oferta convencional: “(você/o senhor/nome), teria/tem interesse em fazer atendimento psicológico" (1.12). A escolha do uso da interrogativa negativa é também significativa aí. De acordo com Heritage (2002), a polaridade da interrogativa negativa é invertida para transmitir uma expectativa de resposta positiva (1. 1-2).

Outro padrão de ofertas desse tipo são as retomadas da oferta em diferentes formulações. A primeira delas se dá de forma atenuada "conversar com um profissional da área de psicologi:a" (1.2-3), evitando, com uma substituição lexical, o que pode ser visto como tabu (atendimento psicológico).

No excerto em exame, a voluntária, valendo-se de um raciocínio lógico do tipo "se/então", parte logo para o oferecimento de marcação do atendimento (se ele tem interesse, ela tem como marcar para esta quarta-feira). Isso leva o assistido a adiar a resposta, inserindo sequências de pedidos de informação sobre o local de atendimento, em sobreposição à repetição da oferta "quer ir?" (1.19-20). Então, a 
voluntária faz uma formulação de lugar (Schegloff, 1972), informando o bairro e um ponto de referência, para que ele pudesse verificar se conhecia o local: "fica no ponto cem réis, perto da igreja [são lourenço]" (1.20-21). Antes mesmo que ela possa dizer o nome da igreja, ponto de referência, ele informa que já sabe a localização: “[eu sei onde é]” (1.24), o que resolveria o problema e responderia ao pedido de informação feito por ele.

Depois de responder aos pedidos de informação do assistido, a voluntária repete a oferta ("quer ir?") (1.20), agora no formato direto. Ainda com relação à orientação da voluntária para a delicadeza do tipo de oferta, observa-se que, em caso de contexto positivo, uma nova formulação aumenta o grau de clareza da oferta “(você/o senhor/nome) quer (X)" (1.20, 26).

Em resposta à primeira vez que a oferta foi feita, Augusto se manifesta receptivo, mas adia uma resposta conformativa que atenda ao que foi perguntado/oferecido. $\mathrm{O}$ atraso na resposta é introduzido pelo marcador (olha), o alongamento da vogal e hesitação (“=olha é: bom-”, 1.4). É, então, com marcas de desprefêrencia que Augusto, alinhando-se à Merida, produz uma avaliação positiva e, com um account, justifica a concordância com a formulação de Merida de que atendimento psicológico é uma conversa com um psicólogo ("é bom às vezes a gente ter alguém que- que esteja disposto a ouvir os nossos [desabafos]", 1.4-5). A fala do assistido aponta também para um reconhecimento impessoal da necessidade de atendimento psicológico, por meio de "a gente" e depois o possessivo "nossos", ambos usados de forma impessoal. Mesmo com esse deslocamento de referência, a resposta de Augusto encoraja a voluntária, como já comentado, a repetir a oferta, em sobreposição à fala de Augusto.

Depois de um pequeno Local Relevante de Transição (1.25), como Augusto atrasa a SPP da oferta, Merida repete a oferta no formato já explicitado: "cê quer ir?” (1.26) -, e, após cinco décimos de segundo, da segunda vez, ele produz o aceite: "sim senhora" (1.28).

Em seguida, trazemos mais um excerto de parte de uma abordagem que envolve esse tipo de oferecimento, dessa vez à assistida Acácia. As voluntárias Merida e Anita fizeram a oferta a ela e receberam como resposta um grande desabafo, em que Acácia expõe sua dificuldade de lidar com os próprios sentimentos e emoções. Nesse ponto, as voluntárias percebem a possibilidade de 
repetirem a oferta, ajustando suas falas à interlocutora. O ajuste da fala ao/à interlocutor/a "diz respeito à multiplicidade de aspectos com que a fala de uma das partes, em uma conversa, é construída ou desenhada, de maneira que demonstre orientação e sensibilidade ao/à outro/a que é o/a coparticipante" ${ }^{\text {56 }}$ (Sacks et al., 1974, p. 727). Além desse ajuste, as voluntárias usam accounts para defender ainda mais que o atendimento poderia ajudá-la, como pode ser visto a seguir.

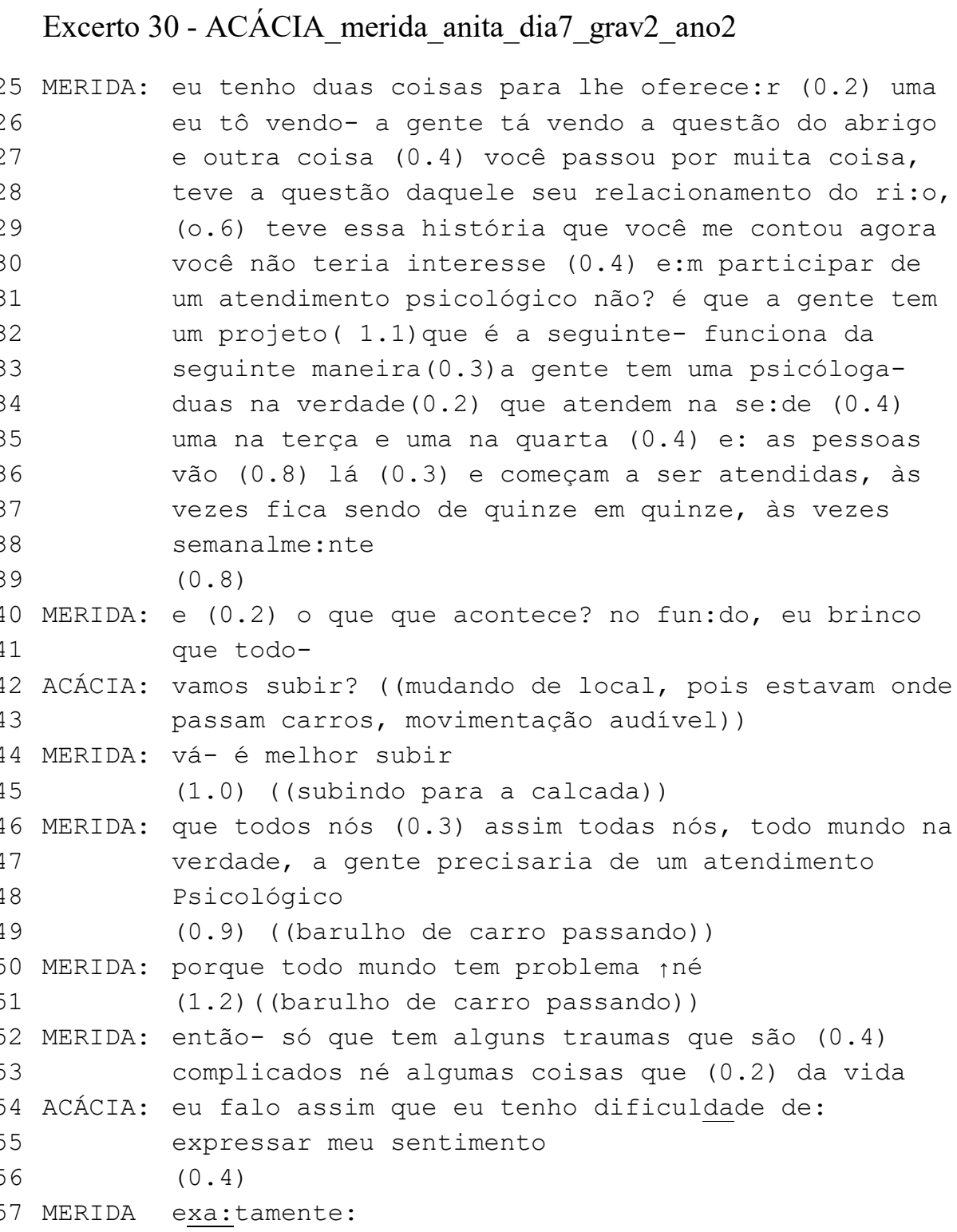

${ }^{56}$ Tradução reproduzida de Andrade, 2016, p. 17. 
A fala de Merida traz uma formulação sobre a ação que ela está prestes a fazer: oferta (1.25). A leitura deste fragmento deixa ver que Merida anuncia duas possíveis ofertas: a de abrigo, sobre a qual ela e a assistida já haviam conversado em outro momento, e que já estaria em análise (1.25-26), e a de atendimento psicológico. Esta última, porém, se estende em uma sequência multiturnos, que se desdobra das linhas 27-39,44-48, e não é anunciada de imediato: antes, a voluntária traz uma account para justificar a oferta, com o co-rememorização (Boldem e Mandelbaum, 2017) de acontecimentos anteriores que levaram a voluntária a pressupor a necessidade e a se apresentar como uma pessoa que a ouviu e pode oferecer algo para ajudar com os problemas compartilhados por ela, embalando a assistida como vítima, sem responsabilizá-la pelo seu sofrimento: "e outra coisa (0.4) você passou por muita coisa, teve a questão daquele seu relacionamento do ri:o, (0.6) teve essa história que você me contou" (1.27-29), para, só depois, por meio de uma interrogativa negativa (Heritage, 2002), que marca a espera pela resposta positiva, formular a oferta, mais uma vez, por verificação de desejo([...] você não teria interesse (0.4) e:m participar de um atendimento psicológico não? [...]”, 1. 29-30). Mas, ao contrário do que de costume, em caso de ofertas, Merida não dá espaço para a resposta imediata de Acácia, uma vez que ela prossegue com possíveis accounts que mostram a disponibilidade do serviço (1.33-34), naturalizam a necessidade desse tipo de atendimento $(1.46-48,50)$ e justificam a oferta $(1.52-53)$, numa tentativa de lidar com uma potencial resistência. Dessa maneira, a PPP é produzida de forma despreferida. A ideia de autoinclusão (1.46-47) minimiza o teor potencial de ameaça em face da assistida, por precisar desse atendimento, segundo a voluntária.

Além disso, Merida acrescenta informações de como o atendimento é feito. Tudo isso pode caracterizar um cuidado e uma atenção da voluntária para uma ação delicada. O primeiro turno de Merida é longo, repleto de alongamentos e pausas, inclusive na oferta, marcando, para sua interlocutora, que se trata de um tópico sensível e, ao mesmo tempo, lidando com a sua emergência na abordagem.

A tentativa de naturalização desse tipo de atendimento foi feita em uma sequência multiturnos, em que houve dois LRTs $(1.49,51)$, mas nenhuma autosseleção por parte de Acácia nem da outra voluntária. A fala de Merida é ajustada à sua interlocutora, pois, além do uso do nome próprio, demonstra-se que 
conversas anteriores estão sendo consideradas, afinal, como vimos, depois de conhecer as necessidades do outro é que se torna possível passar às conduções propositivas e fazer ofertas.

É unicamente depois da afirmação de Merida a respeito do fato de que certas questões são mais complexas que a assistida se autosseleciona e compartilha sua dificuldade de expressar os próprios sentimentos (1.54-55). Recebe como retorno a filiação de Merida (1.57), por meio de um marcador de conclusão que busca conectar o desabafo da assistida à pertinência da oferta e também funciona como possibilitador de continuação das narrativas da assistida, antes do aceite ou recusa, como podemos ver no excerto que segue:

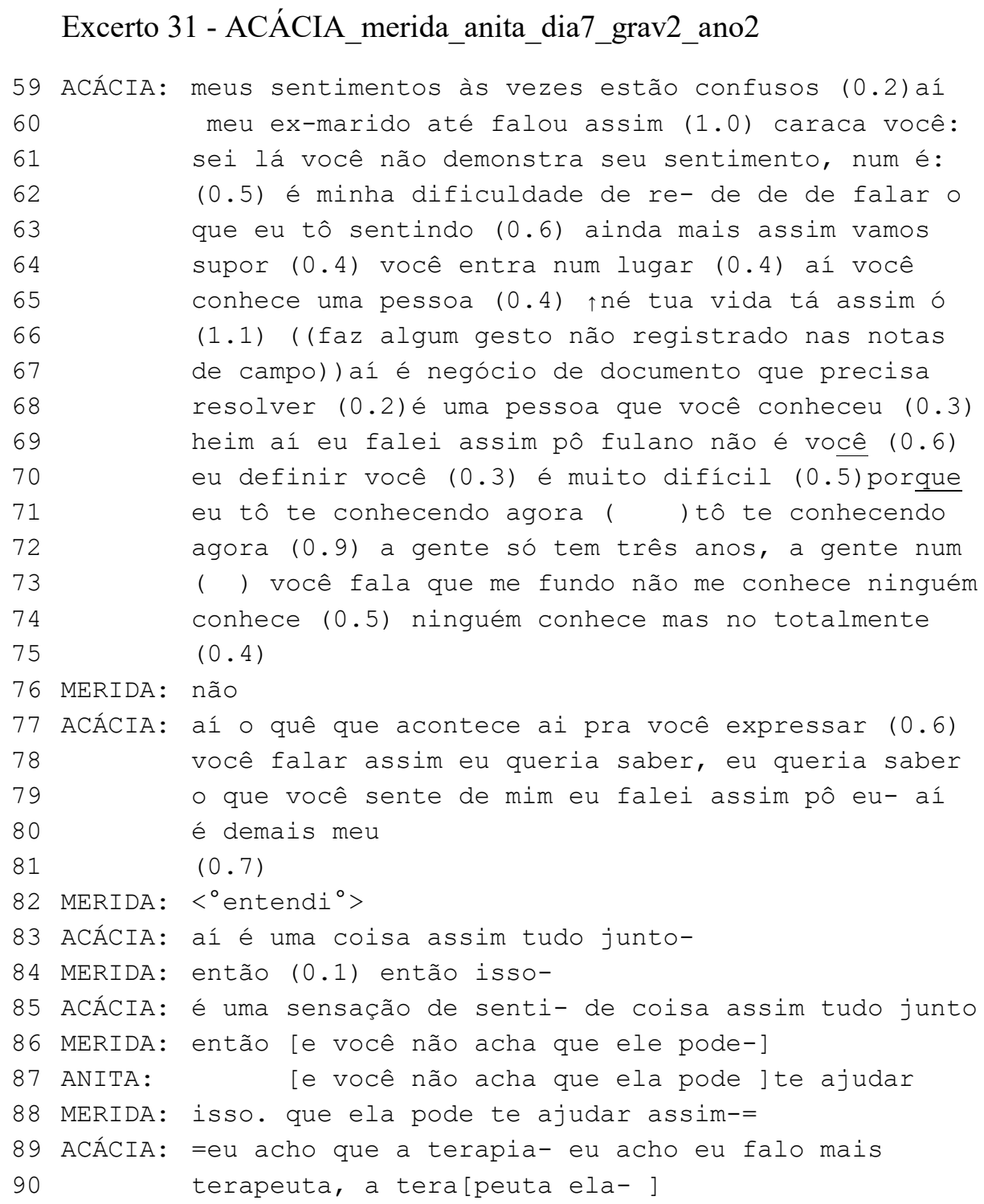




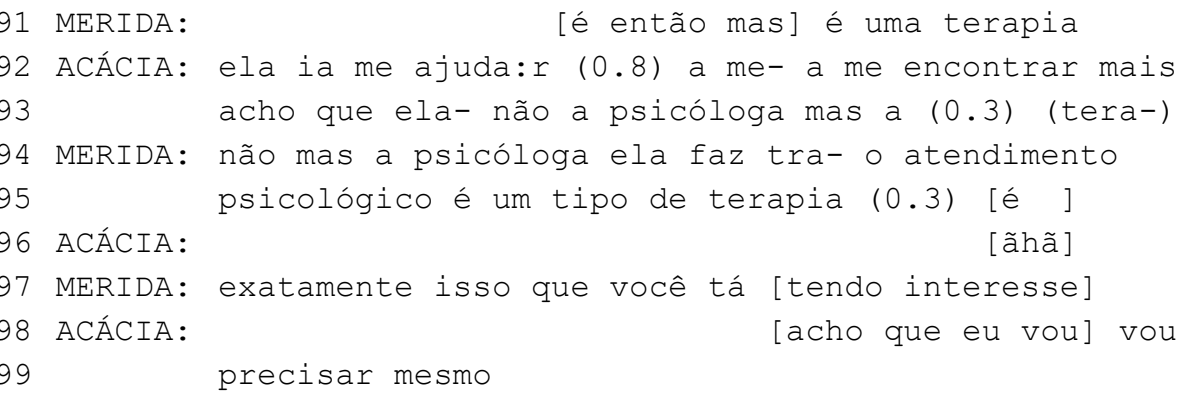

Fez-se necessário desenvolver e aprofundar as explicações, porque a oferta se revelou uma ação delicada, novamente.

Das linhas 54-55, 59 a 74 e 77 a 80, Acácia discorre sobre sua relação confusa com os sentimentos. Após um LRT (1.75), Merida emprega apenas um marcador de concordância minimalista: "não" (1.76), que serve para demonstrar alinhamento com Acácia e encorajá-la a continuar narrando (Mandelbaum, 2013). Esse é o efeito obtido, porque Acácia fica à vontade e prossegue expondo o que sente. Apesar disso, a Acácia não chega a fornecer o aceite ou a recusa à oferta, tendo adiado a segunda parte do par com sequências inseridas. Ela mostra ambiguidade, dada a sua dificuldade de expressar sentimentos, a necessidade de terapia, mas a não compreensão do que seria o atendimento psicológico, fazendo com que ela mostre reserva como sinal de dúvida se valeria à pena.

Um recurso utilizado pelas voluntárias para convencer Acácia foi a de usar os argumentos da assistida para justificar a importância do atendimento psicológico. Mais uma vez, vemos o uso do raciocínio lógico do tipo Se/Então. O modo como as voluntárias respondem ao desabafo de Acácia inicia-se por marcadores de conclusão "então" "então isso-" $(1.84,86)$. No entanto, a assistida as interrompe e não realiza nenhuma ação responsiva com relação a essas conclusões. Com isso, as voluntárias Merida e Anita completam seu sentido, ao coconstruírem uma elocução interrogativa negativa (Heritage, 2002) sobre a possibilidade de o atendimento psicológico ajudar a assistida a lidar com esses sentimentos confusos: "então [e você não acha que ele pode-]" (1.86), "[e você não acha que ela pode]te ajudar" (1.87) "isso. que ela pode te ajudar assim-=" (1.88). A assistida, por sua vez, faz uma interrupção para uma demonstração de dúvida quanto à pertinência da oferta, por meio de discordância em segunda posição (Pomerantz, 1984) tipicamente da forma "Concordo + discordo": "=eu acho que 
a terapia- eu acho eu falo mais terapeuta, a tera[peuta ela- ]" (1.8586), "ela ia me ajuda:r (0.8) a me- a me encontrar mais acho que elanão a psicóloga” (1.88-189).

Ao concordar sobre a ajuda de um terapeuta, mas não a de um psicólogo, Acácia levanta mais uma possível explicação para as dificuldades de realizar aceites desse tipo de oferta: a falta de conhecimento sobre o que é um atendimento psicológico. Ela reconhece que tem problemas em gerenciar seus sentimentos, mas, como acha que só um terapeuta pode ajudá-la, ela discorda que o atendimento psicológico seria útil, no caso dela.

$\mathrm{Na}$ tentativa de desfazer essa dúvida, Merida acrescenta uma informação que a faz mudar de ideia; em sua fala, faz um autoreparo: ela inicia a palavra 'tratamento', mas corrige para definir o atendimento psicológico como um tipo de terapia: "não mas a psicóloga ela faz tra- o atendimento psicológico é um tipo de terapia" (1.91-92). É interessante notar que o termo "tratamento" associado a esse tipo de oferta só foi usado uma vez (excerto 29) e não teve nenhuma recorrência em nossos dados, o que pode ser considerado um gerenciamento da emergência do tópico nas interações.

Essa informação acrescentada por Merida faz com que Acácia aceite a oferta de forma modalizada, isto é, mitigada, enfraquecida pelo "acho" e reforçada no account: "vou precisar mesmo" (1.94-95), que mostra o possível reconhecimento da necessidade. Podemos dizer que se trata de um aceite, ainda que modalizado, pois as voluntárias passam, então, a acertar os detalhes da ida de Acácia, como o dia aprazado, a hora e o apoio com o pagamento da passagem, visto que a assistida não dispunha de meios para arcar com o custo.

Nota-se, pois, que as PPPs indicam que as voluntárias entendem a oferta de atendimento psicológico como uma ação delicada, fazendo uso dos recursos e ações supracitadas para lidar com a emergência dessa oferta e das dúvidas ou desabafos que surgem nas sequências inseridas. É interessante notar, ainda, que, como os casos apresentados não tiveram resistência real por parte das pessoas atendidas, foi possível dar sequência aos ajustes de marcação do atendimento. Por meio da sequência dessas interações, podemos dizer que esses aceites foram facilitados pelo conhecimento prévio do que seja a natureza desse tipo de trabalho, por parte dos/as assistidos/as, uma vez que a maioria deles/as relatou já ter feito algum tipo de 
terapia ou o desejo de fazê-la. Isso também pode ser verificado, por exemplo, ao avaliarmos o modo como se deram as aceitações de Lorena, Augusto, que já tinham recebido atendimento psicológico, e Acácia, que embora não soubesse ao certo do que se tratava o atendimento psicológico, de alguma forma, sabia que estava associado a questões emocionais, pelas suas narrativas, e sentia vontade de fazer terapia.

\section{3.}

\section{O par Oferta-Resistência}

A literatura descreve a Oferta como uma ação que pode ter como segunda parte do par ou o aceite ou a recusa. No entanto, em nossos dados, observamos que muitas vezes a SPP é adiada para futuras interações. Essa suspensão da segunda parte se dá mediante sequências inseridas (Shegloff, 2007), de ações que mostram resistência ou dúvida sobre o que fazer: se aceitar ou recuar a oferta.

Como mostraremos, nessa seção, todas as vezes que as voluntárias encontraram resistência, isto é, ações que inviabilizavam o fechamento do par, elas mostravam uma conduta persuasiva como gestão de receptividade (Humă, Stokoe e Sikveland, 2018) e acabavam propondo o adiamento da resposta, dando um tempo para que o/a assistido/o pudesse pensar um pouco mais, antes de tomar a decisão de aceitar ou recusar a oferta.

As ações de resistência referem-se às ações que vão repudiar as ofertas, ou por força dos estigmas de senso comum ou por falta de conhecimento do que é um atendimento psicológico ou por não reconhecimento da necessidade da ajuda. A resistência diante da oferta revelava também que os assistidos podem morar embaixo de um viaduto, dormir sobre um papelão, pedir esmolas, usar drogas, não seguir regras de higiene, vestir roupas sujas, andar descalços, mas não perderam o autorrespeito, não querem ser vistos como doentes, com problemas de saúde mental.

O excerto a seguir mostra alguns dos padrões de resistência encontrados no corpus. Para apresentar um caso completo, examinamos vários excertos de um caso característico de resistência prolongada, a oferta de atendimento psicológico ao assistido Cláudio, cujas etapas de aproximação e de sondagem da interação foram 
analisadas no capítulo 6. Logo após essa fase inicial da escuta, Merida e Cláudio conversaram sobre o Centro de Atenção Psicossocial (CAPS) do município de Niterói e o uso de bebidas e de drogas ilícitas, entre outras questões. Na sequência, a voluntária introduziu o tópico "atendimento psicológico", cujo fragmento dessa introdução está explicitado nas linhas seguintes:

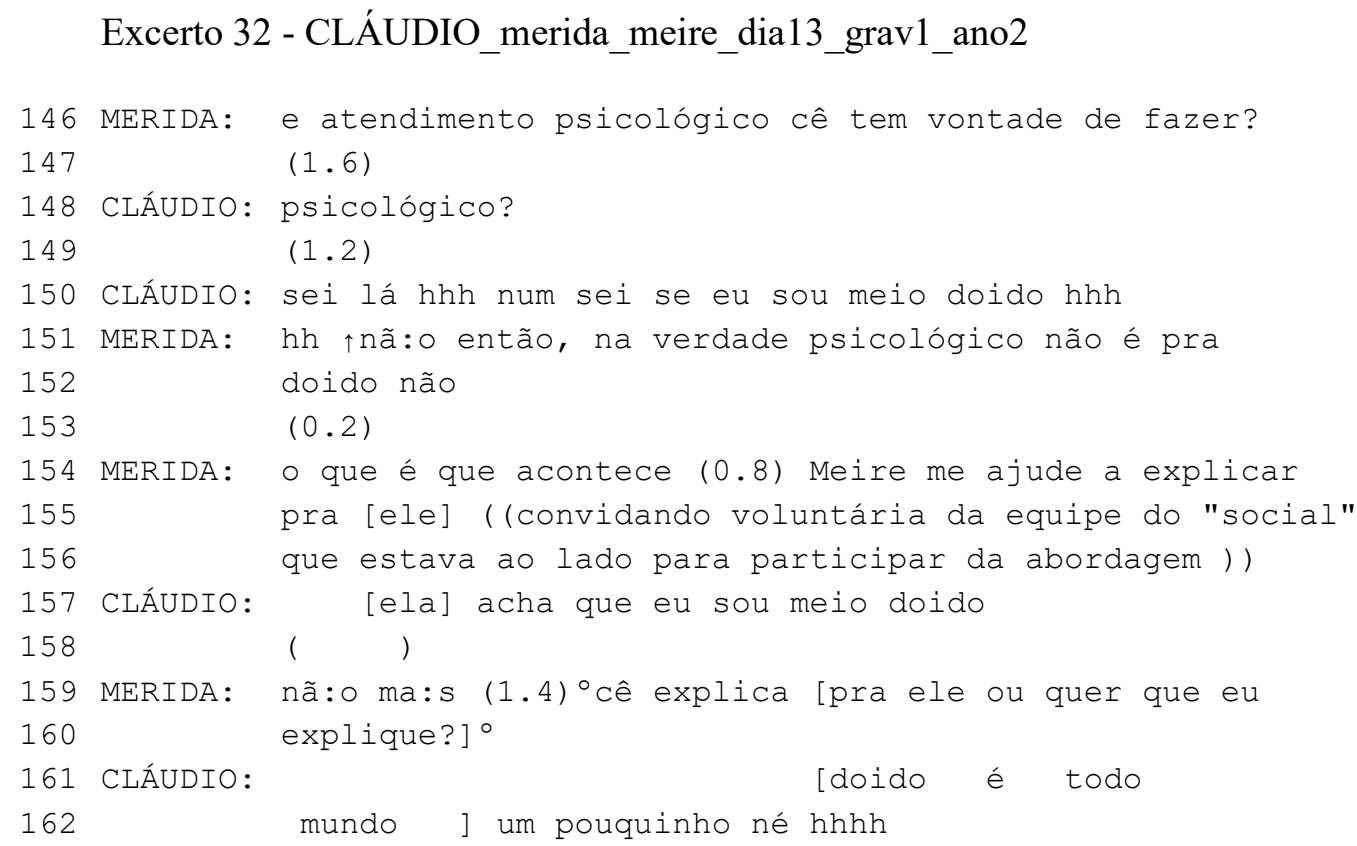

Merida produz a primeira parte do par adjacente por meio de uma oferta indireta convencional, semelhante às já apresentadas, uma verificação de desejo sobre a possibilidade ("e atendimento psicológico cê tem vontade de fazer?", 1.146). Esta oferta tem o objetivo de verificar o interesse de Cláudio em relação ao serviço prestado. A resposta do assistido, porém, apresenta resistência, com marcas de despreferência/tópico delicado, com atraso da resposta: há uma pausa de 1,6 segundo (1.47), que já demonstra um problema com a oferta, mas, como a voluntária não faz nenhum reparo e nem toma o turno, Cláudio responde com uma sequência inserida, que pode ser entendida como um pedido de confirmação do que foi ouvido ("psicológico?"1.148). Mas pelo que se segue a interrogativa aponta para um questionamento sobre a pertinência da oferta feita por Merida.

Após uma pausa de 1,2 segundo (1.149), que marca um Local Relevante de Transição, em que talvez a voluntária tenha fornecido a confirmação, por meio de 
algum gesto ou olhar, Claudio justifica a sua surpresa com o oferecimento, já que não se reconhece com o perfil de alguém que procura atendimento psicológico, o doido: "sei lá hhh num sei se eu sou meio doido hhh"(1.150). Os risos, quase no início e no final do turno (1.150), e as pausas marcam a presença de uma ação delicada (Bergmann, 1998): o fato de o assistido demonstrar entender que o atendimento psicológico se destina a doidos concede à pergunta o potencial ofensivo de compará-lo a um indivíduo mentalmente doente. A fala de Cláudio revela o motivo da resistência; a crença no estigma associado a quem faz atendimento psicológico.

Merida nega enfaticamente a interpretação de Cláudio ("hh $\uparrow$ nã $: \circ, 1.151$ ) mas apenas por meio de uma negativa da afirmação do assistido ("hh $\uparrow$ nã:० então, na verdade psicológico não é pra doido não" (1.151-152). O riso, no caso, marca a afiliação ou não entre as partes (Adelsward,1989). Como gestão da receptividade à resistência de Cláudio, Merida parece fazer uso desse alinhamento seguido de discordância de que psicólogo seja para doido, que assinalaria a tensão e a ambiguidade geradas pelo entendimento de Claudio. Assim, a voluntária tenta corrigir a interpretação de Claudio e, consequentemente, anularia a sua categorização como maluco.

Em seguida, Merida inicia o que parece ser uma explicação ("o que é que acontece" (1.154), mas acaba deixando em suspenso o que teria para dizer ao convidar Meire para explicar o que é atendimento psicológico (1.154-155).

Sem uma explicação, Claudio se dirige à Meire reafirmando o seu entendimento sobre a oferta de Merida: "[ela] acha que eu sou meio doido" (1.157). Mais uma vez, Merida tenta corrigir as consequências interacionais provocadas pela oferta "nã: o ma:s" (1.59), no entanto, novamente suspende uma possível explicação perguntando a colega se ela vai explicar ou se isso fica a cargo de Merida mesmo. Ainda orientado pela crença equivocada, Claudio introduz uma explicação de senso comum: a loucura generalizada ("[doido é todo mundo] um pouquinho né hhhh", 1.161-162), finalizando sua fala com um riso unilateral.

Como revela o estudo de Adelsward (1989), o riso unilateral é usado para modificar expressões verbais ou atitudes e pode ajudar as pessoas a lidar com ambiguidades e tensões, o que parece ter acontecido no caso aqui analisado. Por um lado, ele entende a oferta de Merida como se ela o categorizasse como maluco. Por 
outro, ao se defender reconhecendo a loucura generalizada, ele também categoriza Merida como maluca.

Desta vez, a resistência se prolongou mais do que a dúvida de Acácia e levou a caminhos de negociações que precisaram ser mostradas aqui para vermos de que forma se chegou ao adiamento da segunda parte do par dessa oferta. Por isso, na continuação, há uma negociação do (des)entendimento sobre o atendimento psicológico, como podemos ver no fragmento a seguir.

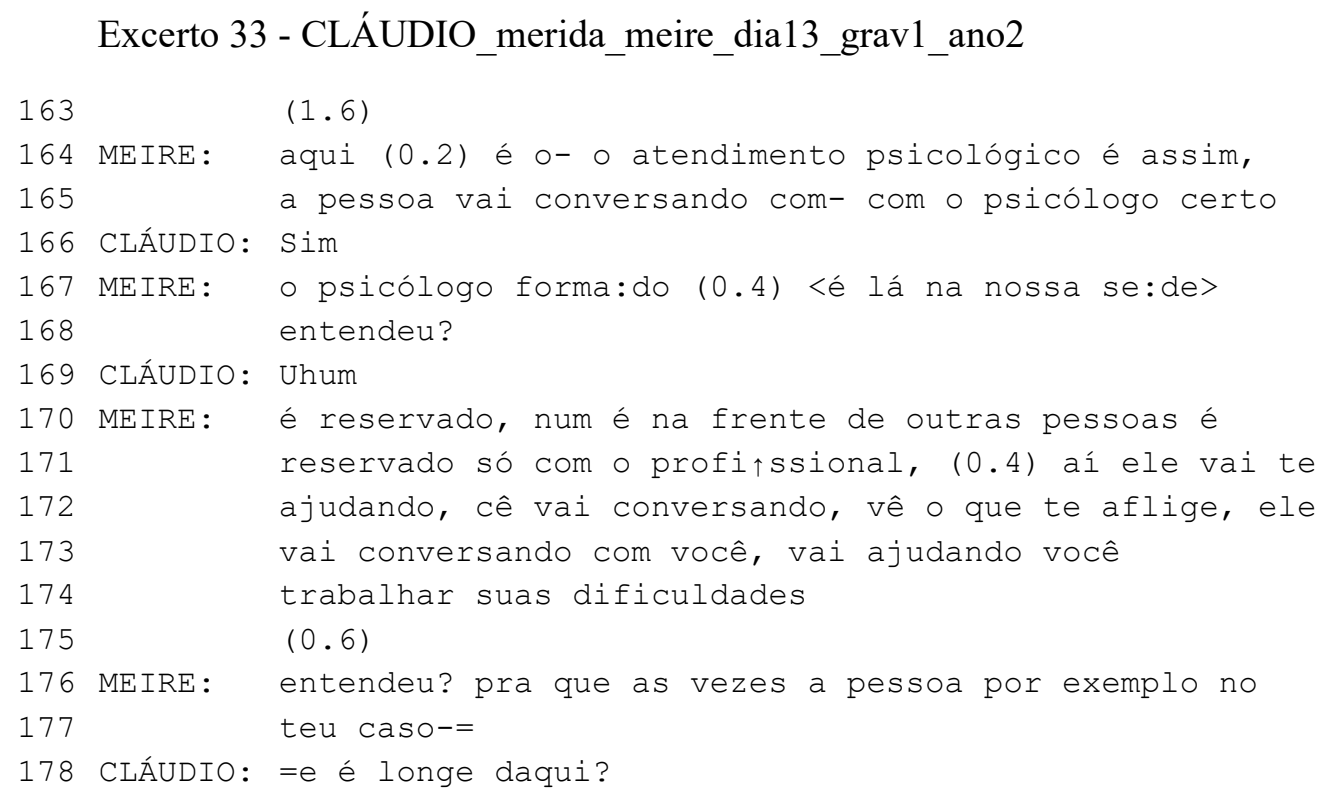

Meire toma o turno já dando início à explicação, fazendo uso do marcador discursivo "aqui", que marca a aceitação ao convite de Merida ("aqui", 1.164). Enquanto Meire explica, Cláudio dá sinais de retorno de que está atento à explicação, por meio dos marcadores de recebimento "sim" (1.166) e "uhum" (1.169). A voluntária faz trabalho de face para não categorizar o outro como louco, ela passa dos exemplos com formas generalizadas ("a pessoa vai conversando com- com o psicólogo certo", 1. 165) às particularizações de sua fala ajustada ao interlocutor numa espécie de segunda tentativa: "reservado, só com o profi个ssional, (0.4) aí ele vai te ajudando, cê vai conversando, vê o que te aflige, ele vai conversando com você, vai ajudando você trabalhar suas dificuldades" (1.171.-174). Tudo isto, no entanto, com pausas em sua fala e hesitação (1.165), marcando sua orientação para a delicadeza da oferta e tentativa de gerenciá-la. 
Na sequência, ocorre um LRT (1.175) em que Cláudio poderia tomar o turno e fazer alguma pergunta, o que ele não faz. Então, Meire segue falando e tentando ajustar sua fala a ele ("por exemplo no teu caso-=", 1.176-177), mas Cláudio a interrompe com uma pergunta a respeito da localização espacial da sede ("=e é longe daqui?") (1.178), interrupção cuja finalidade parece ser buscar detalhes sobre o local onde o atendimento é oferecido, mas que também pode ser interpretado como um pedido de informação para incrementar a sua resistência, já que, na sequência, após negociarem a localização da sede na qual os atendimentos ocorrem e os pontos de referência que facilitam seu reconhecimento, ele diz conhecer pouco Niterói e não saber exatamente onde seria, linhas omitidas aqui.

Depois disso, na primeira oportunidade, Meire retoma o tópico da explicação sobre o atendimento psicológico e continua a desenvolver seu mandato institucional (Drew e Heritage, 1992) do momento, numa terceira tentativa, como consta no fragmento a seguir:

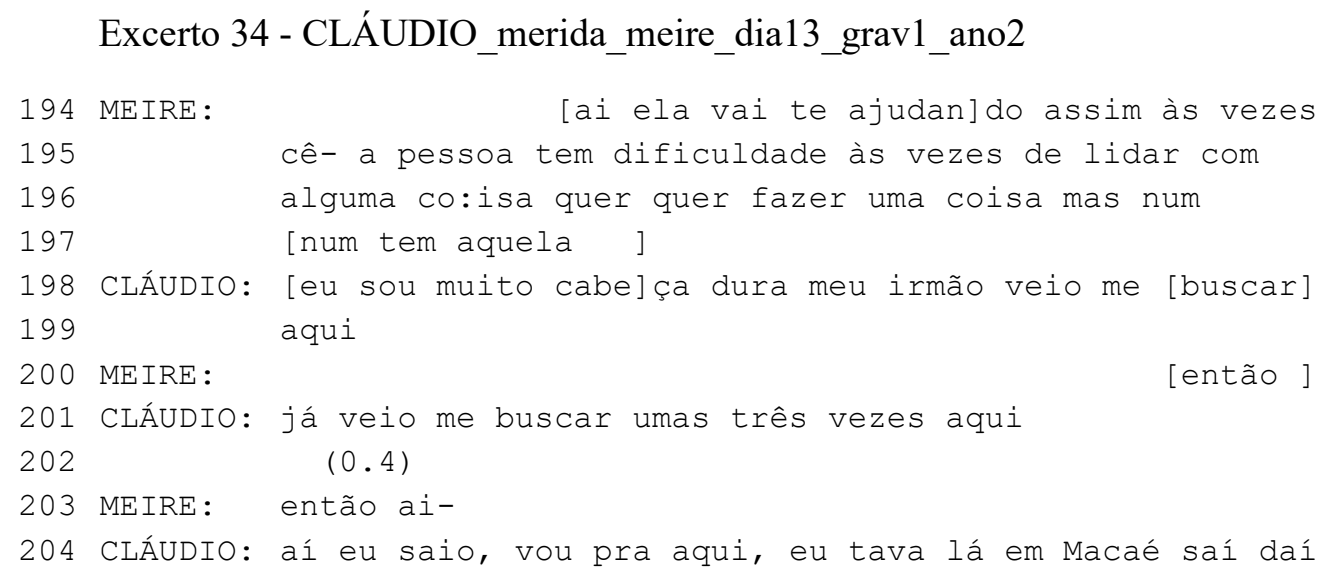

Meire segue dando a explicação a Cláudio (1.194-197), mas ele toma o turno em sobreposição à fala da voluntária e traz um account por meio da pequena narrativa sobre "ser cabeça dura", o que estaria relacionado com o assunto da dificuldade de lidar com algumas situações e de agir. $\mathrm{O}$ assistido também reconhece as questões psicológicas ao associá-las à questão do irmão, que insiste em tirá-lo da rua, sem sucesso (1.198-199). Essa associação pode ser interpretada como uma nova justificativa para uma resistência, acrescida de uma prova/evidência: o irmão já tentou buscá-lo por três vezes, mas ele se recusa a ir com o irmão. 
Como medidas de gestão da receptividade, Meire dá sinais de retorno por marcadores de conclusão "[então]" (1.200), "então ai-" (1.203) tentando responder à narrativa de Cláudio. Mas, como no caso Acácia, anteriormente analisado, o assistido continua sua história sem se orientar para o que a voluntária está dizendo.

Depois disso, nas linhas 204-215, há uma interrupção da conversa, por conta da movimentação da equipe do alimento, que verifica a necessidade de sopa para o Cláudio. Superada essa interrupção, Meire vem como uma quarta tentativa, que pode ser vista no excerto a seguir:

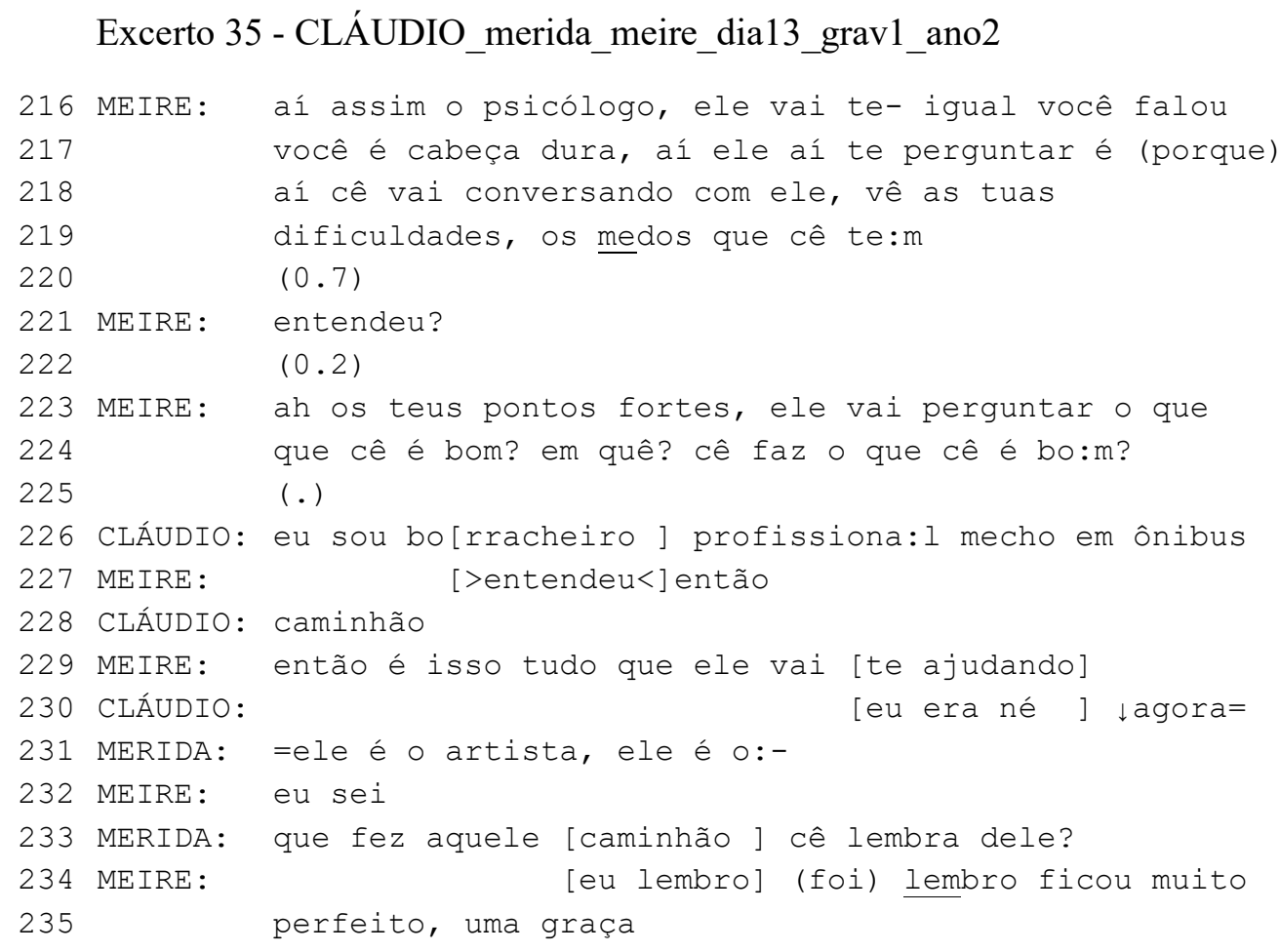

$\mathrm{Na}$ conduta persuasiva de Meire, ela inicia seu turno com um marcador discursivo que opera como indexador de continuidade "aí assim" (1.216) e retoma o account que Cláudio havia usado e poderia justificar a sua não participação no atendimento psicológico, como argumentação de que esse tipo de atendimento o ajudaria a melhorar essa questão (1.216-219), ao ajustar sua fala ao Cláudio ela aproveita algo dito por ele para fortalecer seus argumentos/explicações sobre a oferta. Em vez de exemplos generalizados, Meire continua direcionando sua fala a Cláudio, o que faz com que cada vez mais ele fale sobre si mesmo e acrescente 
informações/narrativas que podem vir a ser importantes para a sua reinserção social embora ele não responda ao marcador discursivo "então" (1.227), que funciona mais uma vez como indexador de conclusão, fazendo com que ela formule uma elocução completa sobre essa conexão e a possibilidade de a terapia poder ajudá-lo (1.229).

Meire faz variar a granularidade da explicação e traz no excerto anterior falas reportadas de perguntas que poderiam ser feitas pelo/a psicólogo/a ao ajudar o assistido na construção do plano de ação para a sua vida (1. 217, 223-224), mostrando que terapia não é só sobre dificuldades, mas também sobre descobertas de pontos fortes. Cláudio, porém, não faz uma ação de concordância ou discordância, parece mais uma tentativa de dizer que ele sabe seus pontos fortes (suas habilidades profissionais), ele também pode ter interpretado essas possíveis perguntas como um pedido de informações sobre si, ao começar a falar sobre suas habilidades profissionais (1.22). Sua ação responsiva deixa claro que ele está acompanhando a explicação. Em sobreposição ao final do turno de Meire, Cláudio faz um reparo do tempo verbal, autocorrigindo-se de "sou" (1.226) para "era" (1.230), fazendo alusão à sua situação de rua do momento seguida de marcador discursivo "né" (1.230), que funciona como intensificador de busca por consentimento.

Em fala colada à de Cláudio, Merida não discorda, mas tenta ressaltar suas habilidades profissionais atuais (1.231). Ambas as voluntárias fazem referência a seu encontro anterior com Cláudio, no qual tiveram a oportunidade de ver um dos caminhões artesanais feitos por ele com materiais recicláveis (latas de refrigerante ou de cerveja) trazendo uma co-rememorização para fortalecer o ponto de vista delas de que se trata de um "artista". Com isso, as voluntárias tentam, juntas, (re)construir uma identidade positiva de Cláudio, retomando a parte de identidade atual que pode ser valorizada. Assim, Merida o caracteriza mais uma vez como "。 artista" (1.231) e Meire usa os adjetivos "perfeito" e "uma graça" (1. 235) para referir-se ao caminhão, atribuindo-lhe um valor extremamente positivo, reforçado pelo advérbio de intensidade "mui to" (1.234). Uma vez que o assunto do artesanato surgiu, Cláudio narra como a arte entrou em sua vida, o que pode ser visto no excerto a seguir: 
Excerto 36 - CLÁUDIO_merida_meire_dia13_grav1_ano2

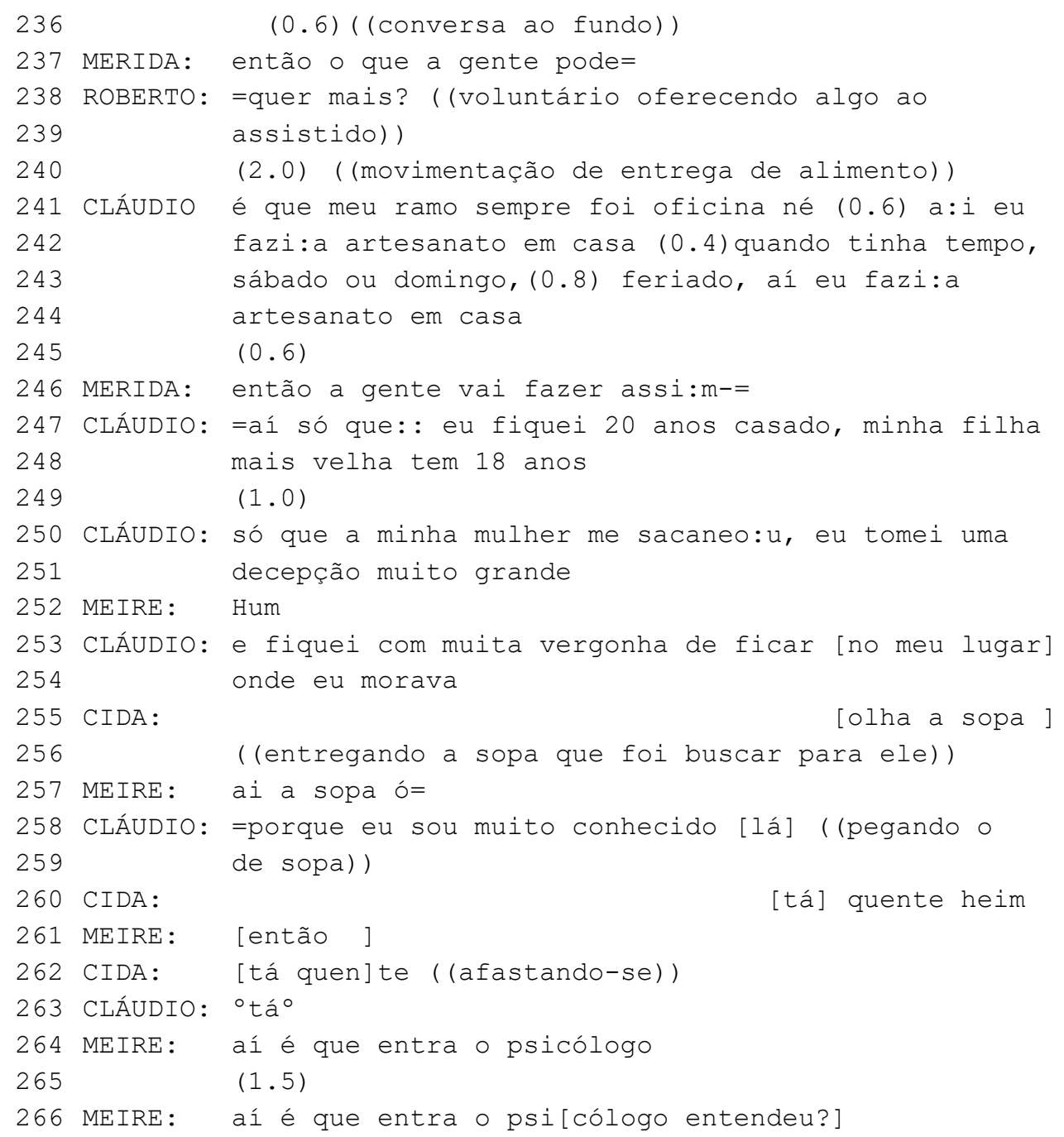

Merida toma o turno, por duas vezes, usando o marcador discursivo "então" e tentando propor algo ("o que a gente pode=", 1.237; "então a gente vai fazer assi:m-=", 1.246), talvez iria finalizar a abordagem, tentar marcar a terapia ou propor o adiamento da resposta, mas, em ambas as vezes, ela é interrompida, primeiro por um voluntário da equipe de alimentos, depois pelo assistido, que demonstra que ainda não havia terminado sua narrativa, ele não parece querer encerrar o tópico naquele momento, ainda quer continuar compartilhando seus problemas/sofrimentos. A pequena narrativa contada por ele era apenas a entrada para a sua narrativa principal, atentamente ouvida pelas voluntárias.

Stivers (2008 apud Mandelbaum, 2013, p.500) observa que os receptores da narrativa podem encenar uma orientação específica de duas maneiras distintas: 
alinhamento e afiliação. Mandelbaum (2013, p. 500) afirma que o alinhamento se refere à orientação que um receptor toma a respeito do estado atual da conversa, tratando-a como uma narrativa, mostrando um entendimento de que houve um ajuste do arranjo para o turno-a-turno de fala, com contribuições mínimas dos/as receptores/as, até que a narração seja possivelmente concluída. Dessa forma, podemos dizer que as voluntárias se alinharam com Cláudio e sua narrativa, tanto que, no LRT seguinte (1.249), nenhuma das duas se autosselecionou para tomar o turno, deixando-o à vontade para que desse mais detalhes de sua história. Além disso, em dado momento, Meire deu apenas uma contribuição mínima, um sinal de retorno de que estava acompanhando a narrativa, ao fazer uso do marcador de recebimento "hum" (1.252). Essa escuta está diretamente relacionada com a principal ação da condição propositiva: a oferta, pois ela traz informações que as voluntárias usam no ajuste à fala do Cláudio.

Meire usa a narrativa de Cláudio, mais uma vez, para dar mais sentido à oferta do atendimento psicológico, sendo enfática ao repetir a elocução duas vezes ("aí é que entra o psicólogo" "aí é que entra o psi[cólogo entendeu? ]") $(1.264,266)$ e sugerir que o/a psicólogo/a poderia ajudá-lo com os seus sentimentos em relação ao fato vivenciado, mas sem formular bem como poderia ser essa ajuda. Na sequência, Cláudio diria algo, mas Merida o interrompe para concordar com Meire, que desenvolve mais esse raciocínio, como consta no fragmento a seguir:

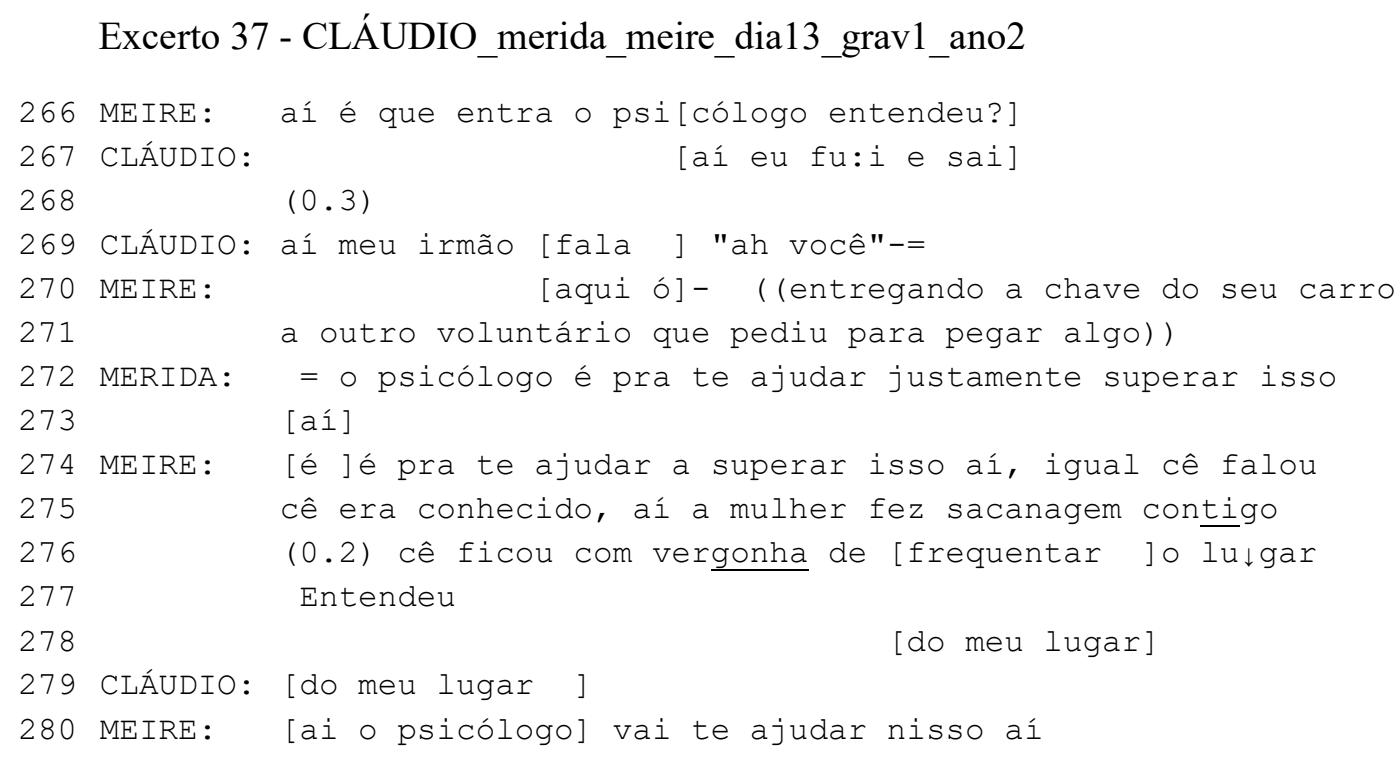




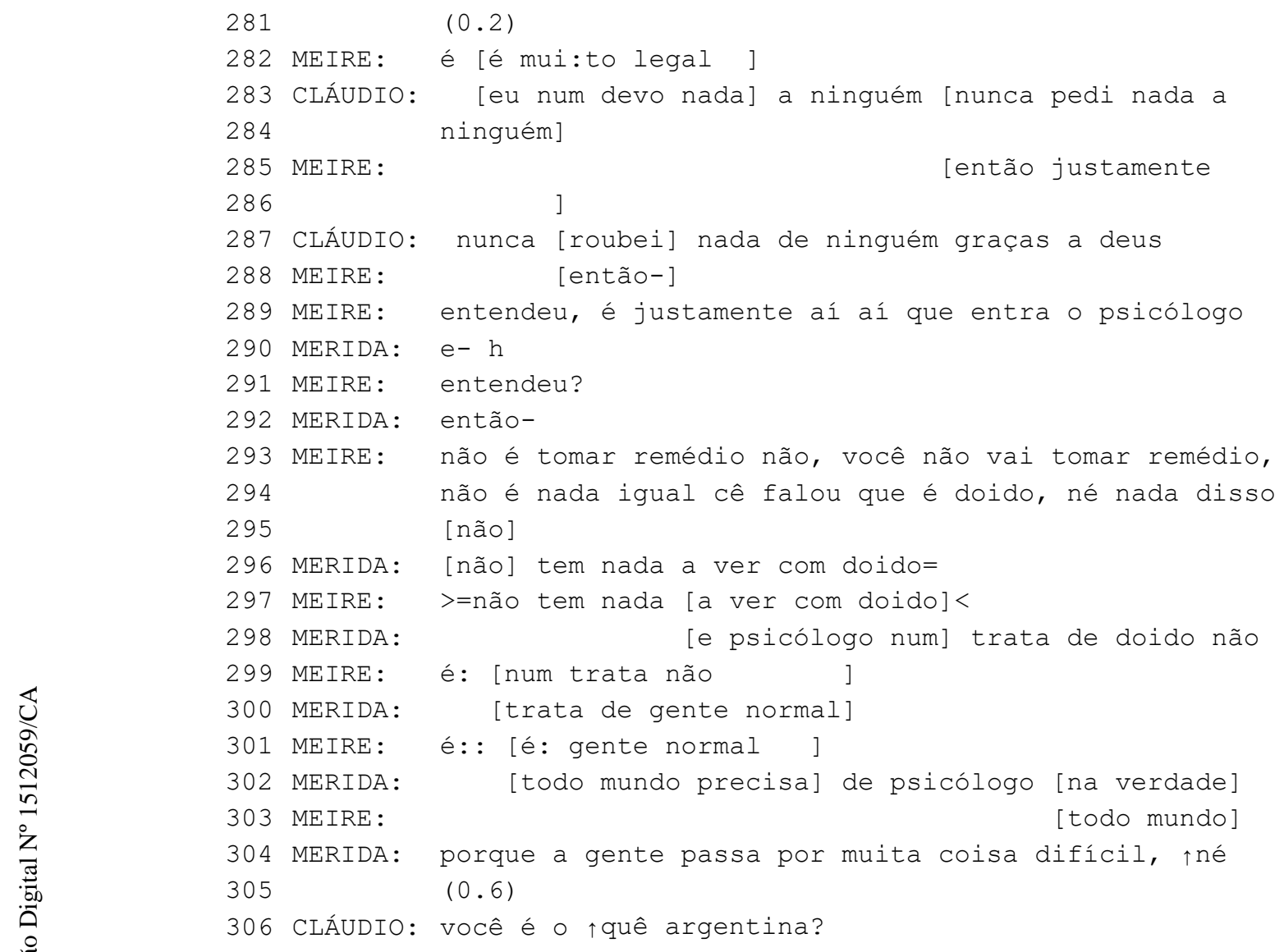

As voluntárias estão empenhadas em usar as informações ouvidas na narrativa de Cláudio para defender a importância da oferta feita, tanto que continuam a usar marcadores de conclusão $(1.285,288,292)$ tentando conectar suas narrativas à necessidade desse atendimento, embora não tenham retorno de Cláudio. Dessa forma, as voluntárias tiram conclusões sobre as informações apresentadas por Claudio, seus sofrimentos e as consequências desses sofrimentos conectandoas à possível ida de Cláudio para a rua e à possibilidade de a psicóloga o ajudar a superar esses sofrimentos, retomando sua autoestima e seus pontos fortes. Meire ainda endossa sua defesa com uma avaliação positiva desse tipo de atendimento (1.282).

Nas sequências argumentativas das voluntárias, vemos accounts e esclarecimentos que fazem parte da conduta persuasiva delas e envolve diferentes ações. Elas retomam a discordância de que o tipo de atendimento oferecido é para maluco (1.293-301), reforçando seus argumentos com a coconstrução da normalização da terapia e de sua necessidade diante dos problemas da vida (1.301- 
304), com o intuito de fechar a tentativa de convencimento na qual as duas voluntárias estavam engajadas desde o início da resposta à oferta. Assim, elas seguem coconstruindo seus turnos, em prol dessa defesa. Tanto é que há várias sobreposições entre as linhas 295-303 - sobreposições essas que não são de discordância nem de disputa pela palavra, mas de coconstrução.

O recurso de normalização do atendimento psicológico e da generalização de sua suposta "necessidade", em uma tentativa também de normalizar as dificuldades humanas, também foi utilizado no caso apresentado de Acácia e aparece em praticamente todas as ofertas de atendimento psicológico que tenha ocorrido resistência real, como nesse caso de Cláudio, ou potencial, situação de dúvida da Acácia.

Após essa tentativa de normalização do atendimento, Merida usa o marcador discursivo “ $\uparrow$ né" (1.304) em tom ascendente, que mobiliza o provimento de uma resposta e expõe a preferência pela concordância de sua defesa: de que as pessoas passam por muitas dificuldades e, por isso, precisam de psicólogo. Não obstante, da mesma forma que ele ignora os marcadores de conclusão que dialogam com essa argumentação, ele ignora essa solicitação de concordância, desta vez, por mudança de tópico (1.306). Essas ações responsivas de Cláudio marcam a sua resistência prolongada.

É interessante notar que, em suas narrativas, o Cláudio se categoriza com uma pessoa de bem, honesto $(1.283-284,287)$, podendo inferir-se que as coisas pelas quais ele passou são injustas. Ele, assim, está orientado para suas histórias, sofrimentos e uma avaliação das injustiças pelas quais passou, enquanto suas interagentes parecem estar orientadas para aproveitar tudo de seus relatos e voltar ao tópico da terapia, embora o Cláudio não corresponda e não emita nenhum tipo de concordância ou discordância dos pontos levantados por elas.

Depois disso, entra-se em diferentes tópicos. A entrada em tópicos diferentes acontece algumas vezes na interação, mas como, de certa forma, as voluntárias estão orientadas para o cumprimento de um mandato institucional (Drew e Heritage, 1992), são elas que conduzem a interação e guiam o assistido à discussão pretendida. 
Dessa forma, elas voltam à oferta feita, no intuito de fechá-la. A ação que marca o encerramento de ofertas que têm resistência prolongada é uma proposta de adiamento do aceite ou recusa, como podemos constatar no fragmento que se segue.

Excerto 38 -CLÁUDIO_merida_meire_dia13_grav1_ano2

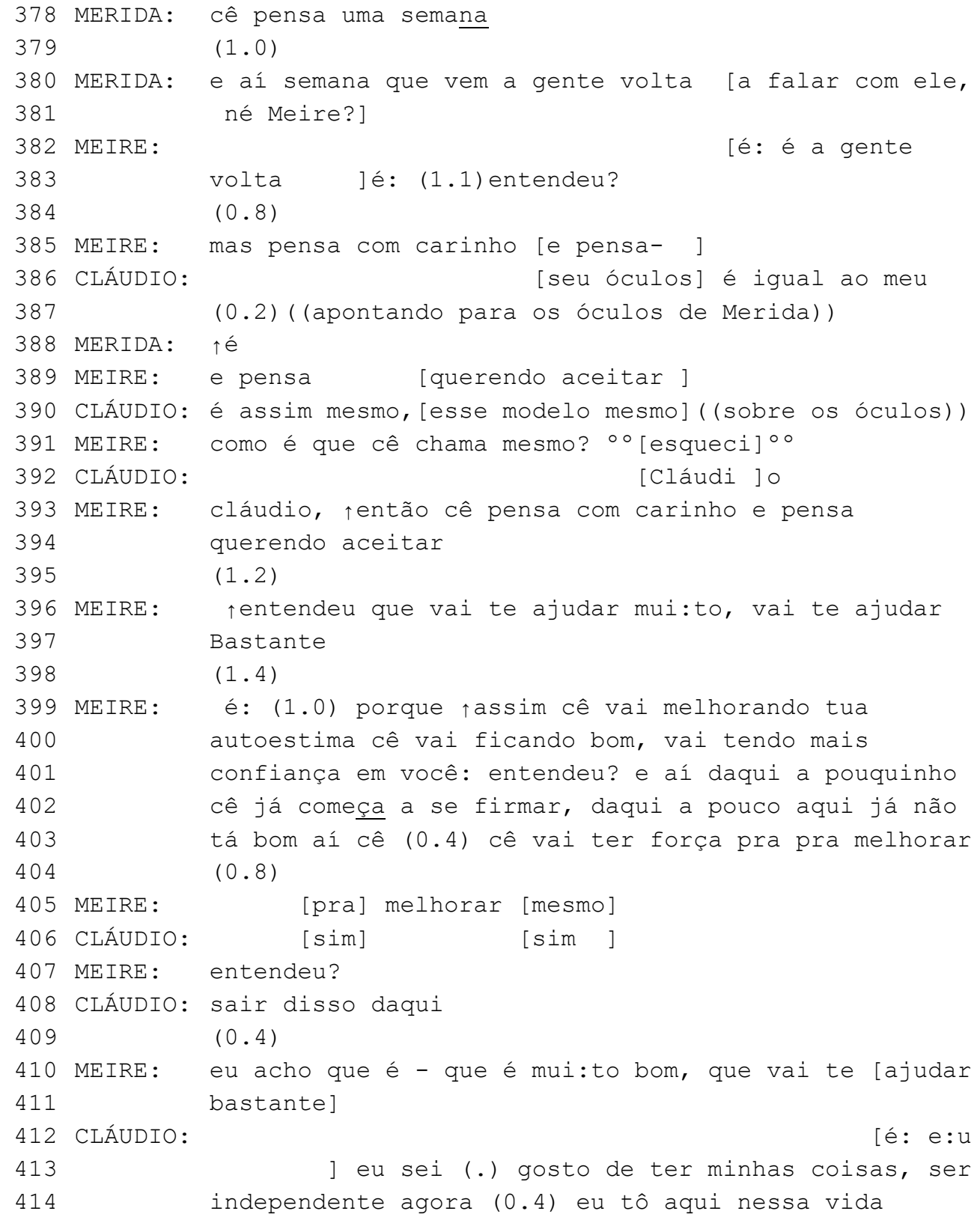

Vemos que há uma proposta coconstruída pelas voluntárias para que Cláudio pense sobre a existência ou não do interesse no acompanhamento psicológico, de modo que ele deveria dar-lhes a resposta no encontro da semana 
seguinte (1.378-385). Como resposta à primeira parte do par, porém, há mais um desvio de tópico (1.386-387), o qual é mantido (1. 390) mesmo com a insistência da proposta (1.389). A ação de Cláudio aponta para a evitação de um aceite ou recusa da proposta, isto é, manutenção da resistência.

Mas, diante da falta de conformidade (Raymond, 2003) por parte de Cláudio em relação à proposta feita, a insistência de Meire em firmar essa proposta permanece ("cláudio, †então cê pensa com carinho e pensa querendo aceitar”, 1.393-394) e é incrementada com avaliações ("vai te ajudar mui: to, vai te ajudar bastante", 1.396-397, "eu acho que é - que é mui:to bom, que vai te [ajudar bastante] ", 1.410-411) sobre a oferta feita, a embalando como uma ajuda para que ele tenha forças e melhore. Isso a leva a fazer um account para justificar o porquê e como o atendimento psicológico pode ajudá-lo, acrescentando projeções de como ele vai ficar, caso aceite ("é: (1.0) porque †assim cê vai melhorando tua autoestima cê vai ficando bom, vai tendo mais confiança em você: entendeu? e aí daqui a pouquinho cê já começa a se firmar, daqui a pouco aqui já não tá bom aí cê (0.4) cê vai ter força pra pra melhorar" (1.399-403), como uma conduta persuasiva.

A princípio, com a insistência, a única ação responsiva de Cláudio é dada por marcadores de recebimento da proposta (“[sim] [sim ]”, 1.406), seguido da sua formulação sobre ter forças para melhorar, resumido como "sair disso daqui" (da rua) (1.408). Depois da avaliação de Meire (1.394-395), ele manifesta sua concordância (“[é: e: u] eu sei”, 1.412-413). Logo em seguida, ele apresenta um account que justifica a concordância e se opõe a estar na rua, nessa vida em que ele não tem as suas coisas e não é independente, como antes (1.414). Assim, houve o adiamento oficial da Segunda Parte do Par, bem como uma insistência para que ele pense sobre a oferta.

O desenvolver dessa oferta sobre a possível inserção de Cláudio no Programa de Atendimento Psicológico se prolongou bastante, devido não apenas à sua percepção do trabalho de um psicólogo, mas também às narrativas que se sucederam e à resistência apresentada. Foi apenas a partir do excerto 37 que as voluntárias introduziram argumentações mais diretas e mais bem fundamentadas sobre a natureza do atendimento psicológico e seu público destinatário. 
É possível dizer que houve uma redução da resistência de Cláudio, porém, apesar de ter diminuído em relação ao início da interação, quando o atendimento psicológico parecia inconcebível, ela ainda continuou alta, pois o assistido sequer respondia aos marcadores de conclusão usados pelas voluntárias. Assim, notamos que, sempre que a resistência persiste, as voluntárias propõem um tempo para que o/a assistido/a pense a respeito, adiando, assim, a resposta e diminuindo as chances de recusa, quando parecem altas.

É interessante notar, ainda, que esse tipo de oferta envolve um tópico que traz problemas de interpretação, seja porque o sentido é de algo destinado aos "malucos" ou por ter seu sentido desconhecido. Ainda que de modo distinto, é interessante notar que o termo "atendimento psicológico" pareceu, no caso de Cláudio e de Acácia, analisados aqui e na seção anterior, não ser familiar a ambos. Suas ações responsivas nos dizem o quanto esse termo parece circular pouco no meio desse grupo social ou como circula de forma preconceituosa, sem que se saiba ao certo do que se trata. Da mesma maneira, nos dois momentos, ele se afigurou de difícil esclarecimento pelas voluntárias, que procuraram descrevê-lo, demonstrando a naturalidade da necessidade de atendimento psicológico e buscando ajustar sua fala ao/à interlocutor/a. Dessa forma, a categoria de atendimento psicológico vem associada a questões negativas e, muitas vezes, a problemas mentais.

Podemos ratificar, ainda, que há uma relação importante entre o conhecimento do/a assistido/a e a ação delicada, tanto que temos um contínuo: Cláudio tem um conhecimento preconcebido, do senso comum; Acácia parece ter um conhecimento maior que ele, associando o termo à necessidade de ajuda para resolver problemas emocionais, embora também tenha preconceito quanto ao léxico "psicológico", enquanto Augusto e Lorena, como já tiveram experiências com esse tipo de atendimento, tratam-no de forma mais natural.

Aqui, apresentamos diferentes ações como maneiras de o assistido apresentar resistência à ação em curso, marcadas por silêncios, uso de accounts para ratificar a inadequação da oferta, afirmação/crença de que o atendimento psicológico é para doido, autocategorização como "cabeça dura" e nãoconformidade (Raymond, 2003) por meio da mudança de tópico, bem como de ignorar marcadores discursivos de conclusão. 


\section{4 .}

\section{A retomada da oferta}

Abordaremos, nessa seção, o caso de Júlio, que teve a oferta anunciada antes de iniciar o funcionamento do Programa de Atendimento Psicossocial, de situações como a de Cláudio, apresentada anteriormente, em que houve um adiamento do aceite ou recusa, ou de remarcações com verificação da manutenção do aceite ou de desistência, em casos que o/a assistido/a possa ter perdido algum atendimento marcado a priori. Mostraremos as regularidades/diferenças de como ocorreu o par oferta-aceite/recusa/novo adiamento, além das sequências inseridas antes da SPP, para entender melhor o caminho interacional percorrido. No caso das retomadas da oferta, tivemos uma ocorrência de resistência prolongada/adiamento, sete aceites e uma recusa velada.

Quando a ação da oferta de atendimento psicológico já foi introduzida em alguma interação anterior, a tendência é que tal oferecimento não apresente (tantas) marcas de delicadeza, pois a ação (mais) delicada já foi feita. Provavelmente, a oferta foi discutida anteriormente com explicações acerca do atendimento e tentativas de justificativas de sua pertinência. Apesar disso, nem sempre essa retomada será menos complexa, no desenvolver da interação, pois, mesmo com a proposta de um tempo para tomada de decisão, no retorno, nem sempre tudo já estará decidido na cabeça do/a assistido/a. Por isso, como mostraremos mediante os dados, ainda ocorre um trabalho de explicação e ações para gerenciar a ação delicada.

$\mathrm{Na}$ ação de recuperar uma oferta, quase sempre, há a atividade de reaver memórias potencialmente compartilhadas para apoiar a oferta e facilitar seu desenvolvimento, numa espécie de reforço argumentativo. Desta forma, uma dos principais recursos de conduta persuasiva encontrados na retomada da oferta de atendimento psicológico é a atividade de co-rememorização ${ }^{57}$, a qual Boldem e Mandelbaum (2017) mostram ser usada por meio de formulações de memória como um método para legitimar ou dar suporte a reivindicações ou ponto de vista em contextos de desafios, objeções, desacordos, ceticismo, resistência e quando

\footnotetext{
${ }^{57}$ activity of co-remembering.
} 
posições alternativas estão em jogo. As autoras indicam que, ao implantar formulações de memória, os/as interagentes confiam no caráter robusto de experiências passadas, em comum, e passíveis de utilização para fornecer uma reivindicação epistêmica atualizada para apoiar uma postura contenciosa em direção a uma posição alternativa.

Assim, nossa análise compartilha de resultado similar ao das análises de Boldem e Mandelbaum (2017), ainda que em contextos diferentes. No sentido de a formulação de uma base de experiência compartilhada usada para uma posição contenciosa, as co-rememorizações atraem os outros para posições particulares e, desta forma, constituem uma colaboração de recursos para administrar as discordâncias/resistências potenciais ou reais.

Como estamos analisando os pares adjacentes, subdividimos esta seção entre a retomada nos casos de anúncio da oferta, 8.4.1; a retomada da proposta nos casos de adiamento, com aceite como SPP, 8.4.2.

\subsection{1.}

\section{Retomada de ofertas anunciadas: aceite e recusa}

Nesta seção, apresentamos duas retomadas de anúncio de ofertas de atendimento psicológico. Quando houve o anúncio, as duas pessoas atendidas se mostraram interessadas na possibilidade de fazer terapia, mas depois só uma delas reafirmou o interesse, que é o primeiro caso mostrado aqui.

O fragmento da interação que segue é com o assistido Júlio, quando a voluntária Merida precisa informá-lo sobre a concretização do Programa de atendimento psicológico e verificar se ele ainda teria interesse, uma vez que, já havia se passado três semanas desde a conversa sobre o assunto e ele poderia ter mudado de ideia.

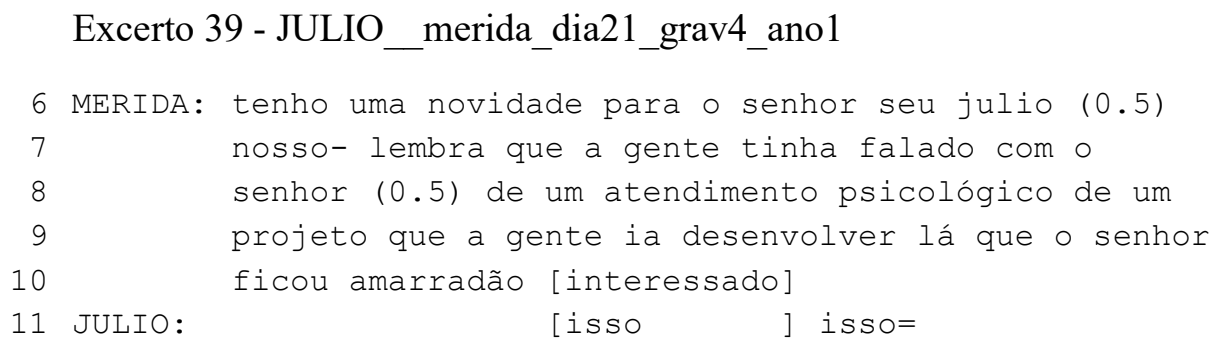




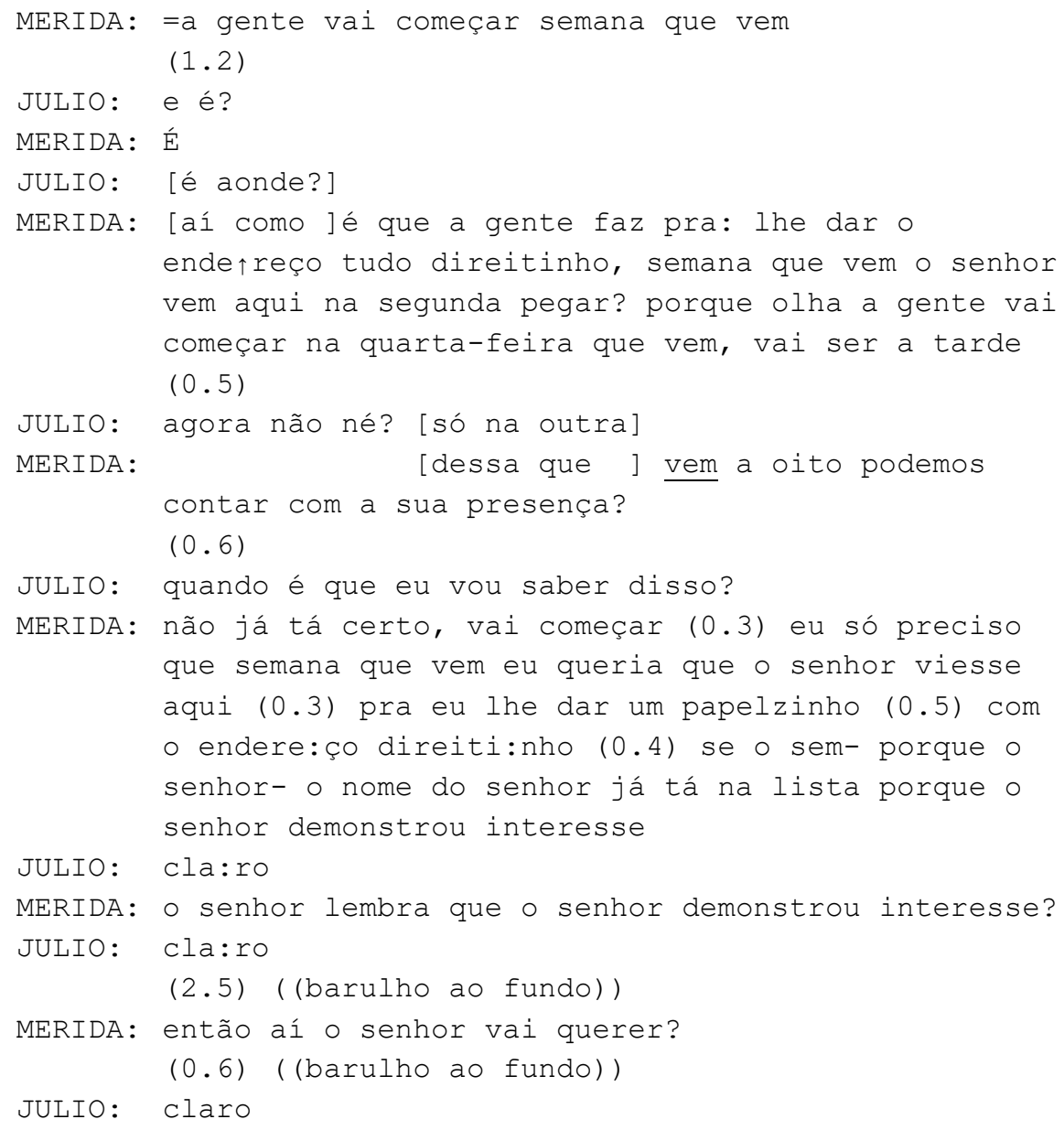

Podemos ver, por meio desse fragmento, como o recurso epistêmico do uso de memórias da experiência compartilhada é usado como conduta persuasiva para introduzir a retomada da oferta de atendimento psicológico.

No caso de Júlio, ele já havia aceitado ir, mas, quando ainda se tratava de algo hipotético, logo seria preciso verificar a permanência do interesse. Para isso, a voluntária começa com o anúncio da oferta "tenho uma novidade para o senhor seu julio", seguido de co-remorizações em formato de pergunta polar para verificar se ele se recorda dessa memória compartilhada, duas vezes: "lembra que a gente tinha falado com o senhor (0.5) de um atendimento psicológico de um projeto que a gente ia desenvolver lá que o senhor ficou amarradão [interessado]" (1.7-10) "O senhor lembra que o senhor demonstrou interesse?" (1.35) e uma vez em formato declarativo ("porque o senhor demonstrou interesse", 1.31-32), como forma de ratificar a pertinência da retomada da oferta e retomar o interesse demonstrado por ele. As ações 
responsivas dele são de concordância com a lembrança ("[isso] isso=", 1.11, "cla:ro", 1.33 e "cla:ro" 1. 36), imediatamente, de forma preferida, com concordância forte e enfática.

Dessa maneira, vemos que a co-rememorização foi usada de forma a tentar garantir a manutenção do aceite de Júlio, trazendo à tona lembranças do seu interesse demonstrado anteriormente, com pedidos de confirmação da lembrança, o que dificultaria a elaboração da recusa por parte do assistido, pois, para isso, ele precisaria de um trabalho interacional maior, como no caso que segue da assistida Alice.

O fragmento a seguir tem apenas a transcrição da parte referente a essa oferta, trata-se da retomada, feita por Merida a Alice, uma das pessoas que demonstrou bastante interesse nesse tipo de atendimento, antes da implementação do Programa, o que estimulou sua concretização, sem que ela soubesse. Depois de iniciado, porém, seu interesse passou a diminuir, pois sempre havia alguma justificativa para a impossibilidade de sua participação, passando a haver uma resistência potencial, como podemos ver a seguir.

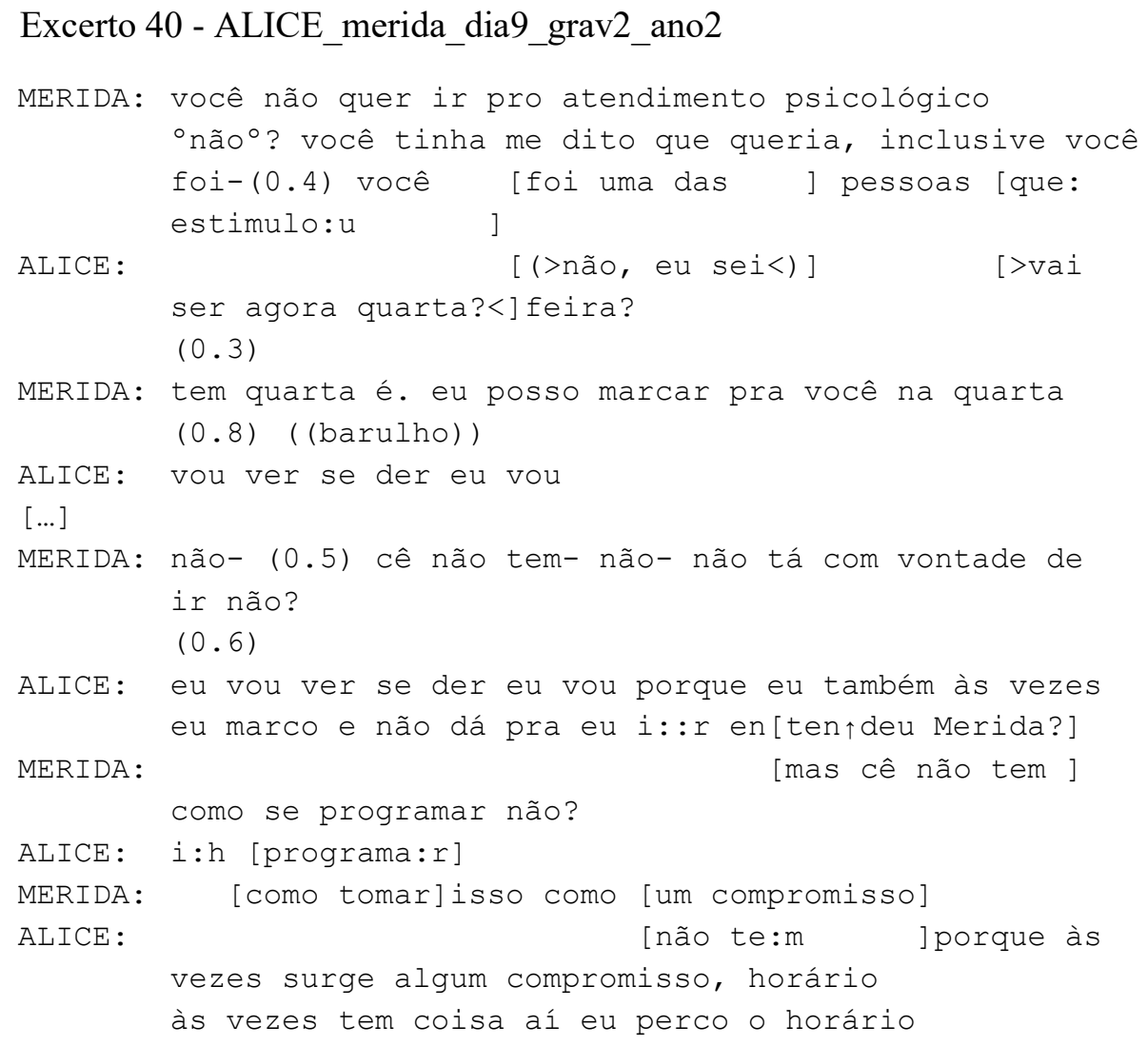


Alice e Merida já haviam conversado algumas vezes sobre o atendimento psicológico, antes de o programa ser empreendido, inclusive havia dito que sentia falta disso, o que estimulou ainda mais a possibilidade do oferecimento desse serviço às pessoas atendidas. Depois de instalado, porém, ela nunca aceitou ou recusou diretamente, sempre adiava a resposta. A transcrição acima foi o único registro de uma dessas tentativas.

É possível observar diferentes condutas persuasivas no fragmento anterior. Primeiro, a oferta é feita por meio de uma interrogativa negativa (1.1-2) e, como já citamos, o estudo de Heritage (2002) defende que esse formato de pergunta transmite uma expectativa de resposta positiva, em que nenhuma das partes interagentes costumam interpretá-la como um simples pedido de informação. Mas não há um espaço imediato para resposta por meio de LRT, a voluntária segue com uma co-rememorização de algum momento que Alice demonstrou que queria ir (1.2) e um account que justificaria o aceite: ela foi uma das pessoas a estimular a implementação do serviço (1.3-4). Essa co-lembrança trazida por Merida não foi das vezes que ela possa ter demonstrado pouco interesse pelo atendimento, mas justamente de quando ela aceitou em algum momento (1.2), como forma de lidar com a resistência potencial da assistida e a ratificar a pertinência da oferta. Assim, a co-rememorização de eventos passados que favoreçam o aceite sempre vem à tona.

Alice, por sua vez, não desfaz da lembrança trazida, pelo contrário, em sobreposição aceita a memória como verdadeira, antes mesmo de a voluntária concluir “[ (>não, eu sei<) ]" (1.5) e traz uma sequência inserida de um pedido de confirmação do dia de atendimento (1.5-6). Merida, por sua vez, interpreta como um possível aceite indireto, fornece a confirmação e informa que já poderia marcála para a quarta seguinte, da mesma forma que fez com Acácia, nas linhas omitidas, após seu aceite indireto. Mas, desta vez, ao invés de passarem aos ajustes, Alice faz um reparo, deixando claro que não se trata de um aceite ainda (1.10).

Depois de uma pequena interrupção para tentativa de entrega de leite (1.1120), linhas omitidas no fragmento, Merida repete a oferta, mais uma vez, pela interrogativa negativa (1.22-23) e Alice repete a sua incerteza com atraso, marca de despreferência, (1.25-26). No entanto, a voluntária insiste com interrogativa 
negativa, questionando a possibilidade de que ela se programe (1. 27-28), e uma formulação a respeito (1.30), que pode ser lida como uma posição retórica da conduta persuasiva para desencorajar a resistência potencial ao curso de ação proposta. Apesar disso, a resposta da assistida continua com marcas de despreferência: alongamentos (1.29) e recusa indireta (Pomerantz, 1984) por meio do account que justifica a sua impossibilidade de assumir compromissos/agendamentos (1.31-33). Trata-se de um fenômeno semelhante ao que Drew (1984) chama atenção na rejeição a convites, em que as pessoas, rotineiramente, afirmam uma incapacidade de fazer algo, em vez de uma falta de vontade de fazê-lo.

Dessa forma, com esse último account, a assistida não fornece uma recusa direta e, implicitamente, ainda chama atenção para o seu cuidado em relação aos compromissos, suas explicações surgem como uma preocupação em não falhar no acerto com a voluntária, o que atenua o peso que teria uma recusa direta e da possível falta de interesse no serviço oferecido para o qual ela havia demonstrado vontade de usufruir, em outro momento.

Essa insistência de deixar algo firmado com a assistida é porque as psicólogas atendem por hora marcada, inexistindo a possibilidade de ela aparecer sem estar agendada para que possa ser atendida. Na sequência da interação, omitida no fragmento, Alice foi informada sobre isso e, mesmo assim, permaneceu com a mesma resposta, o que confirma o fato de se tratar de uma recusa indireta e fez com que a voluntária a informe de que ela poderia falar depois, na semana seguinte ou em outro momento, caso tenha como se programar. Dessa maneira, fica aberta a possibilidade para que a assistida possa solicitar o serviço em outro momento. A pessoa atendida precisa realmente ser agente de sua decisão, pois só ela pode executar a ação em curso. Cabe à equipe de abordagem social gerenciar a delicadeza da ação/tópico, explicar melhor ao/à assistido/a do que se trata, esclarecer todas as dúvidas, como também suspender a oferta, quando a pessoa atendida não quiser se comprometer, como Alice, e deixar que ela exerça sua autonomia na escolha de receber o serviço prestado ou não.

O último excerto apresentado mostra o quanto a ação de recusa é despreferida e, por isso, os/as assistidos/as têm certa dificuldade em fornecer uma recusa direta para esse tipo de oferta, talvez pela relação estabelecida com os/as 
voluntários/as e vergonha de não corresponder às expectativas, afinal ao se oferecer algo que é embalado como "bom" para a pessoa atendida, a recusa torna-se uma resposta difícil. Embora não tenhamos mais dados de recusa gravados, há registro nas notas de campo de recusas indiretas semelhantes, em que os/as assistidos/as atribuem à recusa a impossibilidade de poder comparecer ao atendimento como justificativa para sua não participação e, nunca, a sua falta de vontade.

\subsection{2.}

\section{Retomada de Oferta em que a SPP foi adiada}

Como demonstrado na seção anterior, algumas ofertas de atendimento psicológico podem ter a SPP adiada, em função de ações de negociação da resistência manifestada pelo/a assistido/a. Nesses casos, os/as voluntários/as mostram-se sensíveis à necessidade de dar às pessoas atendidas um tempo para tomarem uma decisão. Esta subseção ilustra a retomada das ofertas tendo como SPP o aceite (8.4.2.1.) ou um novo adiamento (8.4.2.2.).

\subsubsection{1.}

\section{Retomada de oferta-Aceite}

Nesta seção, expomos o excerto de retomada da oferta ao Cláudio, que teve o adiamento exposto na parte anterior desse capítulo. Primeiro, é importante destacar uma limitação dessa análise: a gravação não foi registrada desde o início da abordagem ao Cláudio. Naquela noite, ele estava bastante machucado e iniciou a conversa contando sobre as agressões que sofreu de adolescentes que estavam cheirando thinner, por ele não querer entregar seus produtos artesanais. Só depois de um tempo é que o gravador foi ligado, podendo ter perdido algo da retomada da proposta. As voluntárias participantes da abordagem foram as mesmas da semana anterior: Merida e Meire.

\footnotetext{
Excerto 41 - CLÁUDIO_meire_merida_dia14_grav3e3.1_ano2

15 MERIDA: você já quer ir nessa terça pro atendimento
} 


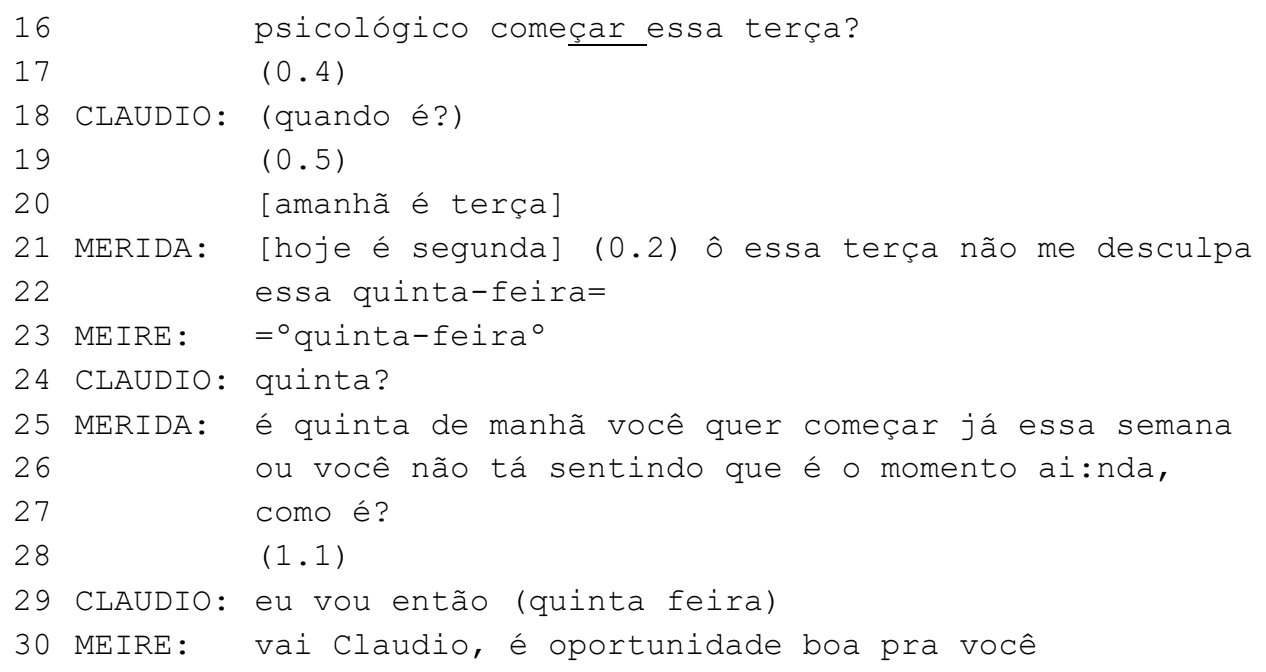

O que aparece nos dados é que, diante do estado de fragilidade emocional de Cláudio, descrita antes da transcrição (e com certeza do que ele falou sobre o que houve), as voluntárias tomam como dado o entendimento de que ele reconhecesse o benefício do atendimento psicológico naquele momento. Tanto isso ocorre que Merida faz uma interrogativa que checa quando ele vai fazer e não se há interesse em fazer, por meio de uma pergunta polar (1.1-2). Mas essa verificação é repetida por meio de uma formulação (1.25-27) que dá mais espaço para que ele não registre o aceite, trazendo a questão da autonomia do assistido, de que ele deve iniciar o atendimento quando julgar ser adequado.

Pode-se dizer que essa retomada iniciou-se com uma imposição do aceite, no entanto, a voluntária dá um passo atrás para ressaltar a autonomia do assistido, com perguntas em cascata (Clayman; Heritage, 2002), isto é, diferentes opções ostensivas do que poderia ser a mesma pergunta: primeiro com uma pergunta alternativa que restringe a opção de ir, mas dá alternativa de quando, seja agora ou no momento que entender ser ideal (1.25-26), e finaliza com uma pergunta aberta (1.27) que cobra alguma resposta ou comentário sobre essa retomada.

Um ponto que confirma esse plano de fundo é que a resposta de Claudio é um pedido de informação sobre o dia do atendimento (quando é). Ele não apresenta mais resistência. Agora é Claudio que conclui que não há mais necessidade de esperar ("eu vou então (quinta feira)"). Em seguida, a voluntária Meire faz uma avaliação de concordância, que formula a ida dele como uma oportunidade (1.30). 


\subsubsection{2.}

\section{A retomada de ofertas e novo adiamento da SPP}

O adiamento da SPP pode ocorrer mais de uma vez, caso a resistência permaneça, podendo ser retomado em interação posterior ou não. Algumas dessas vezes, a equipe de abordagem não retoma a oferta e aguarda que, em caso de interesse do/a assistido/a, a pessoa faça um pedido do atendimento, visto que já tem informações sobre o fornecimento desse serviço pela ONG. Esses pedidos também acabam por ser realizados por outras pessoas que ficam sabendo, por meio de algum/a assistido/a, que a TSN oferece atendimento psicológico. Como é possível imaginar, nesses últimos casos, o trabalho dos/as voluntários/as é bastante facilitado.

Um exemplo que ilustra a resistência prolongada e o segundo adiamento da SPP é o excerto 43, no qual a voluntária Merida tentou apresentar duas colegas voluntárias à assistida Penha, que demonstrou não estar disposta a conhecer outras pessoas da equipe, reação aceita pela voluntária (1.54-58), seguida da retomada do tópico atendimento psicológico com ideia de contraste (1.59), como pode ser visto no fragmento abaixo.

$\mathrm{Na}$ interação anterior a essa, Penha havia desabafado com Merida sobre o seu problema com as drogas, vontade e dificuldade de deixar o vício para poder voltar a sua família em outro estado, além de pedir ajuda para mudar essa situação, pois estava na rua, mas queria sair dela. A conversa foi longa, mas não havia sido gravada, pois Penha ainda não fazia parte da pesquisa, Merida havia dito a ela que teriam como fornecer atendimento psicológico, que ela poderia pensar se gostaria de fazer e, na semana seguinte, retomariam a conversa, da qual o excerto apresentado faz parte.

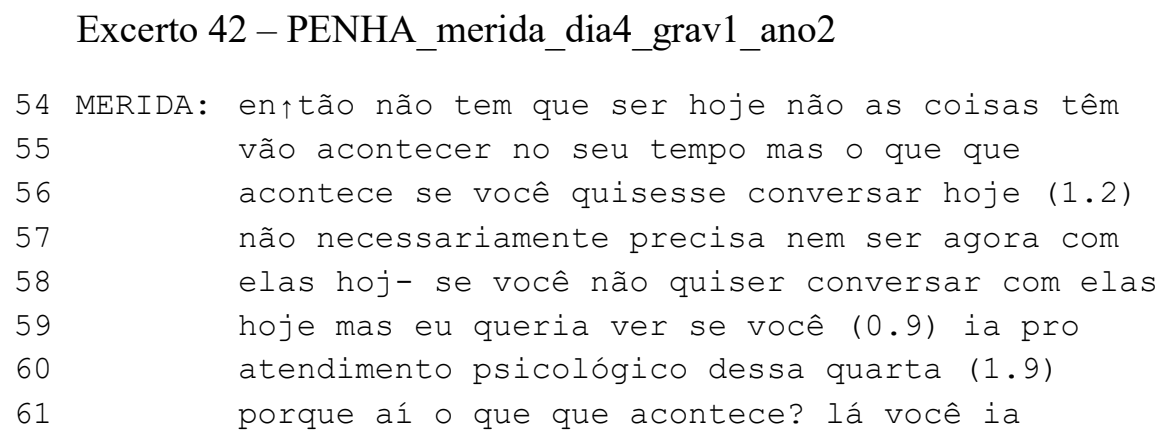




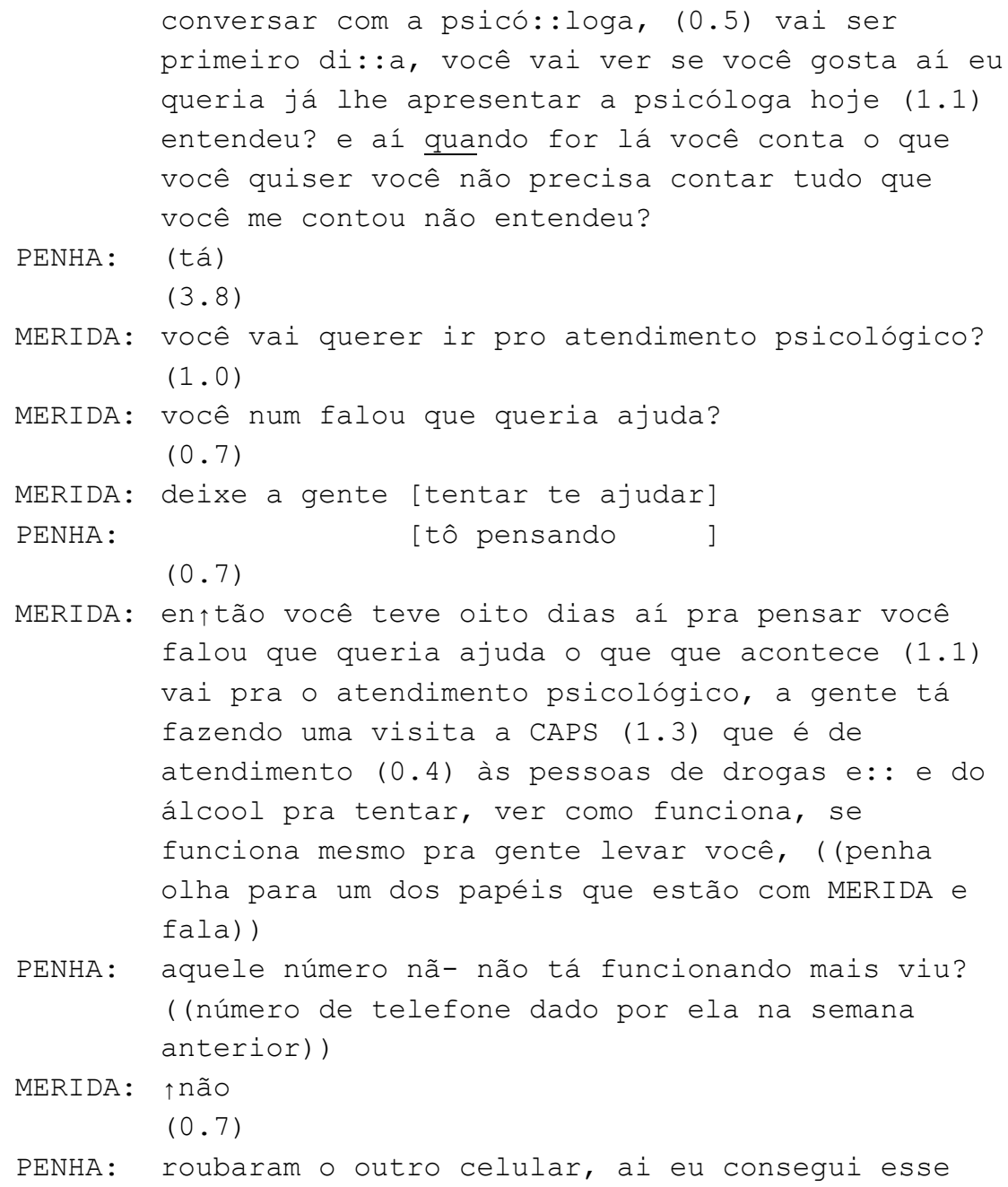

Vemos que o turno da voluntária é longo (1.54-67), cheio de pausas, com alongamentos e hesitações, marcas de despreferência, comuns em ações/tópicos delicados. Antes de repetir a oferta (1.70), verificando a vontade da assistida, ela compartilha a sua vontade de deixar o atendimento marcado (1.59-70), mas seguido de informações e de um account (1.65-67) que enfatiza sua autonomia para falar sobre o que quiser, quando quiser, o que se configuraria em uma conduta persuasiva que minimiza os possíveis motivos de resistência e faz com que Penha manifeste um aceite, ainda que fraco (1.68). Este também pode ser considerado apenas um marcador de recebimento das informações, que parece o caso, como mostra a continuidade da conversa.

As perturbações na fala de Merida, características de tópico delicado podem ser reforçadas por meio do não alinhamento de Penha, com seu silêncio, após a 
formulação da oferta (1.70), que tenta verificar o desejo da assistida conhecer o serviço, formulado como um tipo de ajuda, por meio de uma co-rememorização (Boldem e Mandelbaum, 2017) de algo que a assistida disse no encontro anterior.

A formulação do serviço como "ajuda" pode ser vista como uma conduta persuasiva (Humă, Stokoe e Sikveland, 2018), uma vez que destaca os benefícios para a assistida, o que supõe que diminuirá a possibilidade de uma recusa. No entanto, diante dos silêncios de Penha, Merida retoma a checagem da vontade da assistida para ser atendida. Sem uma ação responsiva da assistida, a voluntária faz uma pergunta retórica que cobra coerência da assistida ("você num falou que queria ajuda?" 1.72), o que é respondido com um novo silêncio. Merida, então, substitui a oferta por um pedido ("deixe a gente [tentar te ajudar]", 1.74). Nesse momento, em sobreposição, Penha apresenta como resposta um account (“[ tô pensando ]", 1.75) que aponta para um novo adiamento da sua decisão (aceite ou recusa).

Merida retoma uma fala de cobrança em relação à indecisão de Penha (1 7778). Mas a assistida parece ignorar a contribuição, propondo, na primeira oportunidade, uma mudança de tópico $(1.86-88,91)$, com uma ação responsiva nãoconformativa, pois não responde a cobrança da voluntária nem com marcador de recebimento. Essa "fuga" do tópico demonstra que a ação persuasiva de Merida é ineficaz.

Após o encerramento do tópico introduzido pela assistida, Merida volta a tentar vencer a resistência de Penha numa sequência multiturnos, agora, porém, dando um passo atrás na ação de cobrar de uma resposta imediata da assistida, como se pode ver no excerto 44 :

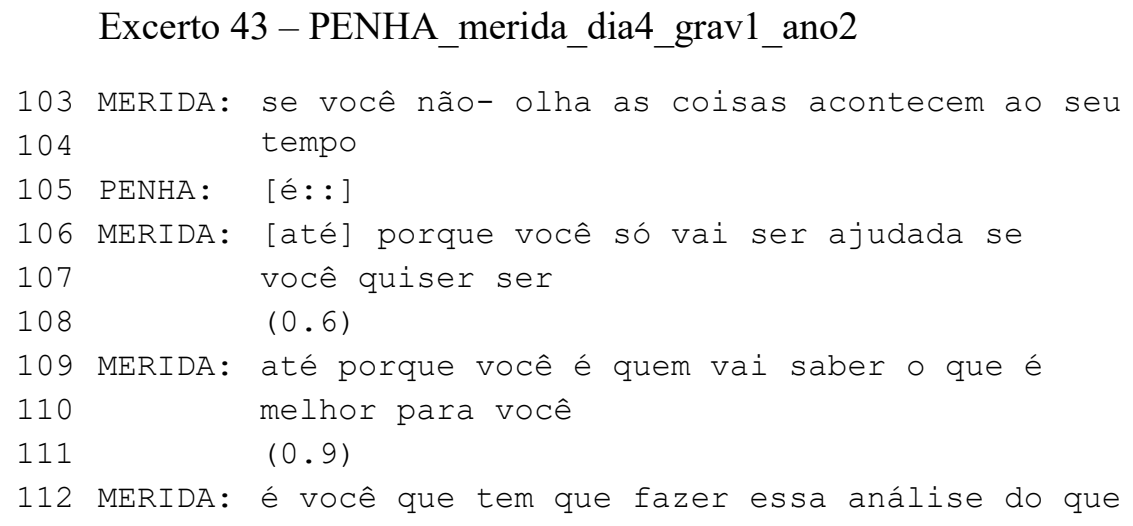




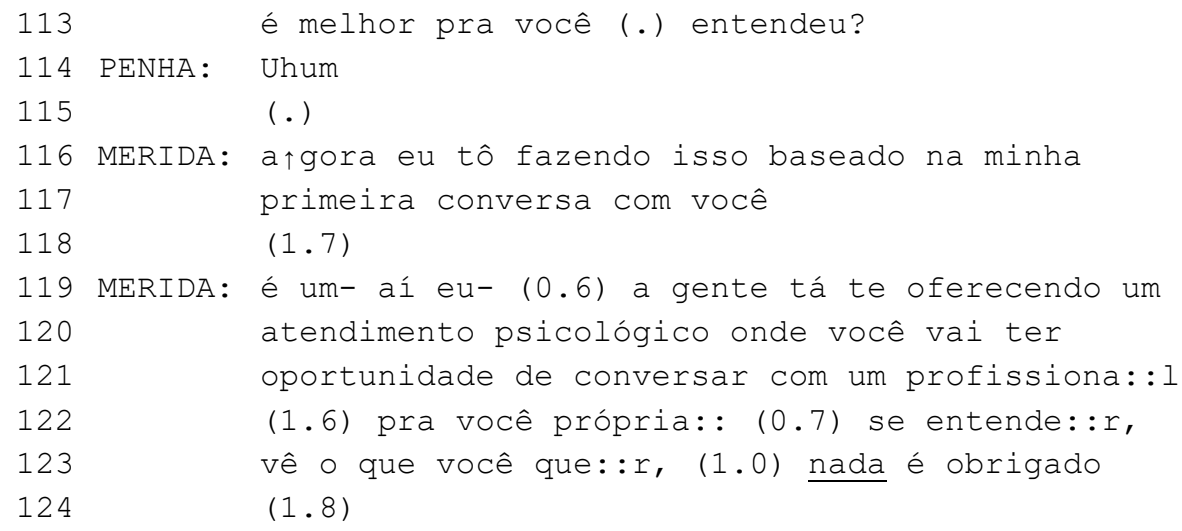

Assim, encontramos, na continuação dessa abordagem, práticas comunicativas que compreendem uma conduta persuasiva (Humă, Stokoe e Sikveland, 2018) por meio do gerenciamento da resistência a partir da minimização da imposição da ida ao atendimento psicológico. Essa conduta acontece com a marcação da agência da assistida em relação a sua decisão, na tentativa de assegurar que ela possui autonomia para ir ou não ao atendimento, pois ela é quem saberia o que é melhor para ela (1.103-104, 112-113), e do account para justificar o porquê da oferta ligado ao atendimento anterior dela (1.116-117). Essa condição é estimulada pela resistência prolongada de Penha que marca o quanto ela não quer fazer diretamente uma recusa, até porque a voluntária insiste em usar a dela sobre a necessidade de ajuda, Penha não toma o turno, após LRTs $(1.108,111,118,120)$, suas únicas ações responsivas são contribuições míninas $(1.105,114)$, depois da formulação da sua autonomia para aceitar ou não. Assim, podemos dizer que a voluntária deu um passo atrás, depois de uma quase imposição, Merida parece expressar respeito ao tempo da assistida.

A voluntária parece fazer uma argumentação em cascata, pois seriam diferentes versões ostensivas do que seria a tentativa de convencimento. $\mathrm{Na}$ sequência, não apresentada aqui, há esclarecimentos sobre como seria em caso de aceite e conversas sobre o vício de Penha, só na linha 203, Merida formula a aceitação da falta de resposta e propõe o adiamento, como pode ser visto no excerto que segue:

Excerto 44 - PENHA_merida_dia4_grav1_ano2 


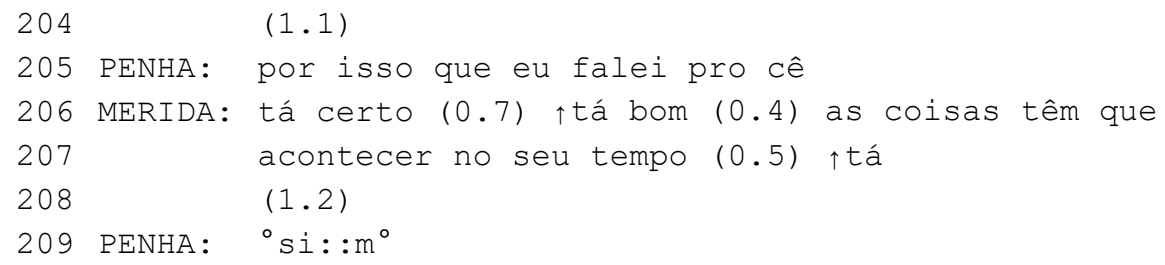

Após a proposta de adiamento seguida de pedido de confirmação por meio do marcador discursivo “ $\uparrow$ né” de forma ascendente (1.203), que convida fortemente ao alinhamento (Stivers, 2006), há mais uma pausa da assistida, mas, como Merida não toma o turno após esse LRT, Penha fornece a confirmação (1.205), que também pode ser interpretada como uma retomada da sua primeira resposta após a insistência da oferta "[ tô pensando ]" (1.75), ratificando, assim, que ainda não está pronta para dar a resposta. A oficialização do adiamento apresentado pode ser visto como o reconhecimento do direito da assistida de que só ela pode determinar o resultado da sequência da oferta e sua consequente ida ou não ao atendimento psicológico, quando e se julgar conveniente (1.206-207), com o qual ela concorda em volume de voz mais baixo e alongamento da vogal (1.209).

Mesmo a resistência prolongada, como a de Penha e de Cláudio, podem ser superadas, mas nossos dados mostram que o que faz essa superação acontecer nem sempre é algo externo, como a conduta persuasiva. Em geral, seria algo interno, inclusive, porque se não for, não vai dar certo. Mas isso ultrapassa os limites da nossa análise proposta para esse capítulo; o principal aspecto relacionado à linguagem e apresentado aqui é que a oferta de atendimento costuma ser uma ação delicada e encontramos marcas disso tanto nas PPP quanto nas SPP. Por isso, apresentamos um quadro sintetizando todas as marcações apresentadas ao longo deste capítulo:

Quadro 4 - Síntese de questões interacionais importantes na análise da oferta de atendimento psicológico

\section{Marcas de despreferência}

- Realizadas pelas voluntárias na PPP:

a) Turnos longos;

b) Hesitação;

c) Pausas;

d) Alongamentos;

e) Formulações atenuadoras por substituição lexical de tabus. 
- Realizadas pelo/a assistido/a na SPP:

a) Silêncios/pausas;

b) Atrasos para fornecer a SPP;

c) Sequências inseridas;

d) Não-conformidade em resposta a algumas ações das voluntárias;

e) Recusa indireta por meio de accounts como falta de tempo, impossibilidade de comprometimento com a ação futura.

- Ações que evidenciam a orientação das voluntárias para uma ação delicada e sua conduta persuasiva:

a) (Co-)rememorizações que justificariam a inferência da necessidade do atendimento e consequente pertinência da oferta;

b) Oferta por meio de interrogativa negativa para aumentar a possibilidade de obter uma resposta positiva;

c) Ajuste de fala ao/à interlocutor/a;

d) Repetição da oferta e de argumentos;

e) Formular a oferta do serviço como ajuda;

f) Accounts para justificar a (pertinência da) oferta;

g) Accounts para normalizar a necessidade de atendimento psicológico;

h) Uso de marcadores de conclusão para conectar os desabafos à pertinência da oferta;

i) Uso de argumentos que poderiam ser contrários tomando-os como favoráveis;

j) Proposta de adiamento da SPP, em caso de resistência prolongada, sugerindo que o assistido pense na oferta;

k) Ressaltar a autonomia do/a assistida/a

Ações dos/as assistidos/as que marcam a resistência/tópico delicado:

a) Silêncios;

b) Uso de accounts para ratificar a inadequação da oferta;

c) Não-conformidade/não alinhamento;

d) Introdução da mudança de tópico;

e) Contribuições mínimas como resposta;

f) Não tomada de turnos após LRTs e falas endereçadas a ele/ela. 


\section{Considerações finais}

A situação de rua é uma das duras consequências da desigualdade social. Com a crise econômica por que passa o país, com os altos índices de desemprego, o número de pessoas em situação de rua tem crescido consideravelmente, inclusive, em Niterói ${ }^{58}$. Diante desse contexto, o trabalho voluntário promovido pela ONG “Turma da Sopa de Niterói” (TSN) vem somar esforços no sentido de atender às necessidades básicas das pessoas em situação de rua e de tentar criar oportunidades para que esses/as moradores/as possam vir a deixar as ruas e ser "reinseridos" na sociedade, embora se tratem de tímidas contribuições diante da drástica realidade e das limitações com as quais a ONG se depara.

Muitas vezes, esbarramos em entraves que dificultam bastante a saída da rua, dentre as quais as principais são: a falta de possibilidades de ofertas de empregos ou de local para moradia digna e problemas de saúde mental. Mas, mesmo nesses casos, a acolhida dada pelos voluntários, por meio do contato e atenção constantes, contribui no que é possível chamar de redução de danos, isto é, conjunto de práticas cuja finalidade é reduzir os danos associados à condição de viver na rua para aquelas pessoas que não podem ou não "querem"59 sair dela.

O trabalho de abordagem social da TSN aqui em foco traz em seu bojo dois problemas. O primeiro diz respeito à centralidade da linguagem na atividade da assistência social. A abordagem, por exemplo, exige conhecimento sobre interação, sobre a organização da conversa, sobre o modo como os significados são coconstruídos,

58 Reportagem já citada, anteriormente, reafirma o crescimento desse segmento social: https://oglobo.globo.com/rio/bairros/abordagens-populacao-de-rua-em-niteroi-mais-que-dobramem-um-ano-23257280> Data de acesso: 10/01/2019

${ }^{59}$ As aspas vêm para problematizar a noção de escolha nesse ambiente, pois acreditamos que escolhas só são realmente possíveis quando se tem acesso a todas as possibilidades e se sabe as consequências positivas e negativas de cada uma delas. Em geral, essas pessoas não têm muitas opções. Muitas das quais conheci, inclusive as que não tinham vontade de ir para abrigo por conta de experiências negativas anteriores, diziam sonhar em ter um cantinho só delas, em que pudessem viver com dignidade e ter seus direitos sociais. Mas não tinham essa opção e acabavam por continuar a viver nas ruas. Dessa forma, não dá para dizer que não aceitar um abrigo ou algo semelhante seja não querer sair da sua condição de rua. O máximo que podemos dizer é que a pessoa escolhe apenas entre as opções que lhe foram disponibilizadas. Dada a heterogeneidade da população em situação de rua, suas vivências e as violências às quais são submetidas (pelo Estado e pela sociedade), é muito difícil falar sobre suas escolhas. 
O segundo diz respeito, especificamente, à capacitação dos voluntários, não só para interagir, mas também para praticar a abordagem social. No caso da TSN, por exemplo, ainda não há um curso de formação específico para os/as novos/as ingressantes, na equipe de abordagem. O processo de aprendizagem é construído na prática. Primeiro pela observação da atuação dos membros mais experientes dessa equipe e, depois, pelo estoque de conhecimentos construídos pela prática, o que nos levou a produzir um arquivo com o registro das principais informações sobre dúvidas dos assistidos. Há reuniões periódicas que contribuem também para o aprendizado, na medida em que não só são discutidas a situação das pessoas atendidas e as possibilidades de ajudá-las, como também há uma busca por reflexão sobre o trabalho desenvolvido e as possibilidades de aperfeiçoamento.

Desta forma, esta pesquisa traz contribuições teóricas e aplicadas, que são apresentadas nas seções a seguir.

\section{1. Contribuições teóricas da tese}

Este estudo traz contribuições tanto relacionadas à dimensão da Organização Estrutural Global da abordagem social, até então não estudada no Brasil, quanto em relação à dimensão de sua organização sequencial. Apesentamos uma primeira descrição, que contém as seguintes etapas da abordagem social: 1) início da abordagem, 2) escuta e/ou sondagens, 3) condução propositiva e 4) fechamento. Esse achado permitiu uma organização da intervenção social, destacando, em suas etapas, o papel da aproximação como o momento interacional que, na abertura, inicia a construção de um vínculo, mas que pode ocorrer em toda a estrutura da abordagem como fortalecedor do vínculo de confiança entre os participantes.

Esta pesquisa revelou não só a centralidade da oferta no trabalho da abordagem social. Os dados revelaram também que o Par Adjacente, Oferta-Aceite/ Recusa também apresentou especificidades no contexto desta pesquisa.

Este estudo também contribui para o entendimento da natureza delicada da ação. Ainda que as ofertas de ajuda tenham como ponto uma ação futura do outro que lhe é benéfica, determinados tipos de oferta podem ser percebidos como delicados, a depender do que esteja sendo oferecido. 
Esse achado foi revelado no modo como os/as voluntários/as formulavam determinados tipos de oferta e como os/as assistidos/as respondiam a essas ofertas. Por exemplo, interações em que as ofertas eram de cursos de chocolate, confecção de cartões ou currículos, orientações para a retirada de documentos, ou serviços como exames oftalmológicos, tratamento dentário, entre outros, eram formuladas no formato preferido, assim como o aceite formulado pelo/a assistido/a.

Já um tipo de oferta como a de atendimento psicológico era sempre formulado pelos voluntários no formato despreferido, mas, em raros casos, tiveram como resposta aceite no formato preferido.

Outro ponto importante diz respeito aos constituintes do par OfertaAceite/Recusa. Nem sempre a Segunda Parte do Par - aceite ou recusa - ocorreu na mesma interação em que a oferta foi produzida. Em muitos casos de tipos de ofertas delicadas, a SPP ficou em suspenso, e ações de resistência ocuparam o seu espaço. As ações de resistência não significaram sempre recusas indiretas, já que a resistência apenas adiava uma tomada de decisão que poderia ser de aceite ou de recusa.

Há, portanto, ainda muito a que ser descoberto sobre o contexto aqui contemplado. Dada a inexistência de estudos da fala-em-interação com foco na ação de voluntários no trabalho de assistência social, esperamos que pesquisas futuras possam vir a aprofundar este estudo com análises constrastivas, seja com relação ao trabalho voluntário promovido por outras ONGs seja com relação ao trabalho de assistência social realizado por profissionais do Serviço Social, bem como que nosso entendimento analítico sobre o corpus gerado seja ainda mais aprofundado.

\section{2.}

\section{Contribuições aplicadas da tese}

Nosso estudo veio a contribuir para uma sistematização do trabalho de abordagem social e para o desenvolvimento de uma metaconsciência interacional, por meio de sessões de análise conjunta dos dados gerados para a tese com membros/as da equipe.

Como mostramos no capítulo das notas de campo, também encontramos e descrevemos as fases da intervenção social, em sentido mais amplo, a saber: 1) 
aproximação, 2) escuta e/ou sondagens e 3) condução propositiva. Elas funcionam como uma engrenagem, ou seja, um conjunto de fases para produzir movimentos rotativos que possibilitem dar visibilidade às pessoas em situação de rua, tratá-las com a dignidade necessária e contribuir para a sua saída da rua, quando for possível, e elas que queiram.

No que se refere às microações interacionais realizadas em cada uma das etapas da abordagem social e aos recursos interacionais mobilizados pelos/as voluntários/as durante a abordagem, foi possível identificar diferentes graus de efetividade.

Destarte, por meio do estudo das interações, foi possível observar que algumas microações se mostraram mais efetivas, a saber: chamar a pessoa pelo seu nome, prática constante e reconhecida pelos/as assistidos/as por meio das notas de campo como algo imprescindível; criar serviços conforme a demanda; realizar ofertas a partir de uma checagem de interesse da pessoa atendida; mostrar sensibilidade para a delicadeza de alguns tipos de oferta, como o atendimento psicológico, marcadas por meio de uma estrutura despreferida; dar um tempo, em casos de resistência, para que a pessoa possa avaliar sua disponibilidade interna para aceitar uma oferta que possa estar associada a significados simbólicos negativos, como a oferta de atendimento psicológico.

Por outro lado, algumas se mostraram menos eficazes. Alguns exemplos foram observados no caso da oferta de atendimento psicológico. Um deles diz respeito ao trabalho persuasivo em caso de resistência em aceitar a oferta. Orientados/as pelo desejo de ajudar, nem sempre os/as voluntários/as são sensíveis, em casos de resistência, ao que está acontecendo na interação, isto é, ao significado das contribuições dos/as assistidos/as. Muitas vezes, eles insistem na oferta de atendimento psicológico, o que pode soar como impositivo, sem observar que contribuições mínimas ou tentativas de mudança de tópico, realizadas pelos assistidos, apontavam para recusa indireta da oferta.

Outras vezes, observou-se que, no esforço de persuadir a pessoa atendida, os/as voluntários/as usavam o marcador conclusivo "então" para estabelecer um nexo entre o problema do/a assistido/a e a 'solução' que seria dada com o atendimento psicológico. Nesses casos, inclusive, observou-se que os/as voluntários/as não perceberam que os/as assistidos/as continuaram falando de suas 
dificuldades, ignorando a fala dos/as voluntários/as. Apesar do nexo criado pelos/as voluntários/as, as falas não representavam um diálogo, com ações responsivas às ações do/a outro/a. A sua escuta só se mostrou ativa, quando foi reconhecida a autonomia do assistido, foi entendida a dificuldade de o assistido aceitar aquela oferta, naquele momento.

Apesar das boas intenções, essas estratégias persuasivas se mostraram ineficazes porque ignoraram que o sucesso da terapia dependerá muito da vontade do/a outro/a fazê-la e do seu comprometimento.

Resistência não se resolve na força argumentativa. É preciso encontrar outros caminhos. É preciso entender mais o/a outro/a, por meio de sondagens/escuta, verificar se há algo que a pessoa queira e que pode ser feito. Caso não haja, é preciso respeitar e focar na redução de danos, dando visibilidade à pessoa mediante tratamento com a dignidade merecida. Essa percepção foi alcançada, ao examinar as respostas aos oferecimentos produzidas pelos/as assistidos/as.

Dessa maneira, os dados apontam também que não basta a equipe de abordagem estar orientada para a delicadeza do tópico, como já ocorre, mas também deve ser mais sensível ao que acontece na interação. Um caso exemplar é o de Penha, em que as ações responsivas da assistida, como os silêncios e as mudanças de tópico, manifestavam, indiretamente, que ela ainda não tinha a resposta, não estava pronta para aceitar ou recusar a oferta.

O crescimento do trabalho voluntário no Brasil vem ocorrendo; o que precisamos, agora, é que a pesquisa sobre trabalho voluntário cresça também. Só assim, o trabalho voluntário pode ser ainda mais transformador. 


\section{Referências bibliográficas}

ADELSWÄRD, V. Laughter and Dialogue: The Social Significance of Laughter in Institucional Discourse. Cambridge: Nordic Journal of Linguistics, 1989, V. 12. p. 107-136.

ANDRADE, D. N. P. Recomendações e prescrições para cuidados de saúde no pós-alta: a investigação de um programa educativo a pacientes cardiopatas sob uma perspectiva interacional. Tese (doutorado) Universidade do Vale do Rio dos Sinos, Programa de Pós-Graduação em Linguística Aplicada, São Leopoldo, RS, 2016.

ANDRADE, D. N. P.; OSTERMANN, A.C.. Formulações (de lugar): Esforço para alcançar a intersubjetividade em audiências de processos penais. Fórum linguistic, Florianópolis, v. 14, n.1, p. 1682 -1698, 2017.

BAGNO, M. Preconceito lingüístico - o que é, como se faz. Edições Loyola: São Paulo, 1999.

BAGNO, M. Gramática pedagógica do português brasileiro, São Paulo, Parábola, 2011.

BALDOCK, J.; PRIOR, D. Social workers talking to clients: a study of verbal behavior. British Journal of Social Work, London, v. II, p. 19-38, 1981.

BASTOS, L. C. Contando estórias em contextos espontâneos e institucionais - uma introdução ao estudo da narrativa. .In: Calidoscópio, vol.3 (2) São Leopoldo: UNISINOS, 2005.

BERGMANN, J. R. Introduction: Morality in Discourse. Research on Language and Social, Interaction, v. 31, p. 279-294, 1998.

BERGSON, H. Le Rire. Essai sur La Signification Du Comique. Paris: Presses Universitaires de France. (1900) 1967.

BINET,M. Microanálise etnográfica de interacções conversacionais: atendimentos em serviços de acção social. Tese de Doutorado em Antropologia, (Especialidade « Produção, Trabalho e Consumo »). Lisboa: FCSH-UNL, 2013.

BOLDEN, G. B.; MANDELBAUM, J. The use of conversational coremembering to corroborate contentious claims. Discourse Studies, v. 19(1) 3-29, 2017.

BOVE, C; FIGUEIREDO, G. População em situação de rua. In. Coleção Caravana de Educação em Direitos Humanos Secretaria de Direitos 
Humanos da Presidência da República - SDH/PR e Faculdade Latinoamericana de Ciências Sociais - Flacso Brasil, Brasília, 2015.

BRASIL. Constituição, 1988. Constituição da República Federativa do Brasil. Disponível em: < www.planalto.gov.br> Acesso em: 23/05/2019.

BRASIL, Lei $\mathbf{N}^{\circ}$ 8.742, de 7 de dezembro de 1993. Disponível em: <https://www2.mppa.mp.br/sistemas/gcsubsites/upload/37/LEl\%208 74293\%20-\%20Assistencia\%20Social.pdf> Data de acesso: 12/05/2017.

BRASIL. Decreto N 7.053, de 23 de Dezembro de 2009. Institui a Política Nacional para a População em Situação de Rua e seu Comitê Intersetorial de Acompanhamento e Monitoramento, e dá outras providências. Disponível em: < http://www.planalto.gov.br/ccivil_03/_ato20072010/2009/decreto/d7053.htm>. Acesso em: 23/05/2019.

BRASIL. Resolução SMDS N. ${ }^{\circ}$ 64, de 12 de Abril de 2016. Cria e Regulamenta

Protocolo do Serviço Especializado em Abordagem Social, no âmbito das ações da Proteção Social Especial de Média Complexidade da Secretaria Municipal de Desenvolvimento Social.

BUARQUE, C. Apresentação: olhar a (da) rua. In BURSZTYN, M.(org.). No meio da rua: nômades, excluídos, viradores. Editora Garamond Ltda: Rio de Janeiro, p. 19-26, 2003.

BURSZTYN, M.(org.). No meio da rua: nômades, excluídos, viradores. Editora Garamond Ltda: Rio de Janeiro, p. 19-26, 2003.

BYRNE, P. S.; LONG, B. E. L. Doctors talking to patients: a study of the verbal behaviours of doctors in the consultation. London: HMSO, 1976.

CARRETEIRO, T. C. Sofrimentos sociais em debate. Psicologia USP, São Paulo ,14(3), p. 57-72,2003.

CARVALHO, J. E. C de. Violência e Sofrimento Social: a resistência feminina na obra de Veena Das. Saúde Soc. São Paulo, v.17, n.3, p.9-18, 2008.

CLAYMAN, S. E.; HERITAGE, J. Questioning presidents: journalistic deference and adversarialness in the Press Conferences of U.S. presidents Einsenhower and Reagan. Journal of Communication, [S.I.], v. 52, n. 4, p. 749-775, 2002.

COGHLAN, D.; BRANNICK, T. Doing Action Research In Your Own Organization. 2nd edn. Thousand Oaks, CA: SAGE, 2005.

CORACINI, M. J. . (Org.). Identidades silenciadas e (in)visíveis: entre a exclusão e a inclusão. Campinas: Pontes, pp. 150-170, 2011.

COUPER-KUHLEN, E. e SELTING, M. Interactional Linguistics: studying languafe in social interation.Cambridge, UK: Cambridge University Press, 2018.

CUNHA, C.; CINTRA, L. Nova Gramática do Português Contemporâneo.

2. ed. Rio de Janeiro, RJ: Nova fronteira, 1985. 
CURL, S.T. Offers of assistance: Constraints on syntactic design. In. Journal of Pragmatics 38, pp. 1257-1280, 2006.

De MONTIGNY, G. Conversation Analysis for Social Work: Talking with Youth in Care. New York: Routledge, 2018.

DEL CORONA, M. O universo do 190 pela perspectiva da fala-eminteração. Tese (doutorado) - Universidade do Vale do Rio dos Sinos, Programa de Pós-Graduação em Linguística Aplicada, São Leopoldo, RS, 2011.

DE OLIVEIRA, M. C.; LISBOA, C. M. Narratives about Displacement and Stigmatization of Identities. RUSSIAN JOURNAL OF LINGUISTICS, v. 21, p. 320-334, 2017.

DREW, E, \& Heritage, J. Analyzing talk at work: An introduction. In P. Drew \& J. F J Heritage (orgs.), Talk atwork: Interaction in institutional settings. Cambridge: Cambridge University Press, 1992.

DREW, P. 'Speakers' Reportings in Invitation Sequences. pp. 152-164 in Structures of Social Acton: Studies in Conversation Analysis, edited by J. M. Atkinson, and J. Heritage. Cambridge: Cambridge University Press, 1984.

ERVIN-TRIPP, S. Is Sybilthere? The structure of American English directives. In: Language in Society, $n^{\circ}$ 5, pp 26-76. 1976.

FOX, B. A.; THOMPSON, S. A. Responses to WH-Questions in English Conversation. Research on Language and Social Interaction, [S.I.], v. 43, n. 2, pp. 133-156, 2010.

GAFARANGA, J.; BRITTEN, N. Talkingan Institutionin to Being: th Opening Sequences in General Practice Consultations. In: RICHARDS, Keith; SEEDHOUSE, Paul. Applying Conversation Analysis. Basingstoke: PalgraveMacmillan. p. 1-15, 2005.

GAGO, P. C. Questões de transcrição em Análise da Conversa. Veredas, v.6, n.2, p.89-113, 2002.

GARCEZ, P. Transcrição como teoria: a identificação dos falantes como atividade analítica plena. In. MOITA LOPES, L. P. e BASTOS, L. C. (orgs.). Identidades: recortes multi e interdisciplinares. Campinas, SP: Mercado das Letras, 2002.

GARCEZ, P. M. A perspectiva da Análise da Conversa Etnometodológica sobre o uso da linguagem em interação social. In: LODER, L. L.; JUNG, N. M. (Org.). Fala-em-interação social: introdução à Análise da Conversa Etnometodológica. Campinas: Mercado de Letras, 2008. p. 17-38.

GARCEZ, P. M.; FRANK, I.; KANITZ, A. Interação social e etnografia: sistematização do conceito de construção conjunta de conhecimento na fala-em-interação de sala de aula. Calidoscópio, v. 10, p. 211-224, 2012.

GARCEZ, P.; SCHULZ, L. Olhares circunstanciados: etnografia da linguagem e pesquisa em Linguística Aplicada no Brasil. DELTA [online], vol.31, n.spe, pp. 1-34, 2015. 
GARCEZ, P; BULLA, G, da S. e LODER, L. L. Práticas de pesquisa microetnográfica: geração, segmentação e transcrição de dados audiovisuais como procedimentos analíticos plenos. DELTA vol.30 no.2 São Paulo jul./dez. 2014.

GARCEZ, P. M. Formas institucionais de fala-em-interação e conversa cotidiana: elementos para a distinção a partir da atividade de argumentar. Revista paLavra, Rio de Janeiro, v. 8, p. 54-73, 2002.

GARDELLA, É., LE MÉNER, E., \& MONDÉMÉ, C. Les funambules du tact: Une analyse des cadres de travail des équipes mobiles d'aide du Samusocial de Paris. Paris: Observatoire du Samusocial de Paris, 2006.

GARFINKEL, H. Studies in ethnomethodology. Engle wood Cliffs: Prentice-Hall, 1967.

GOFFMAN, E. On face work: ananalys is of ritual elements in social interaction. Psychiatry: Journal for the Study of Interpersonal Processes, v. 18, p. 213-231, 1955.

HERITAGE, J.C.; WATSON, D. R. Formulations as conversational objects. In: G. PSATHAS (org.), Everyday Language. New York, Irvington Press, pp. 123-162, 1979.

HERITAGE, J.; ATKINSON, Max. Introduction. In: ATKINSON, J. Maxwell; HERITAGE, J. Structures of Social Action. Cambridge: Cambridge University Press, 1984.

HERITAGE, J. Conversation Analysis and Institutional talk: Analysing Data. In Silverman, D. (2.ed) Qualitatative Research: Theory, Method and Practice. p. 222-245, 1997.

HERITAGE, J. C. Etnometodologia. In. GIDDENS, Anthony; TURNER, Jonathan (Org.) Teoria Social Hoje. Trad. Gilson César C. de Sousa. São Paulo: UNESP, 1999.

HERITAGE, J. The limits of questioning: negative interrogatives and hostile question content. Journal of Pragmatics, [S.I.], v. 34, n. 10-11, p. 1427-1446, 2002.

HERITAGE, J. Questioning in medicine. In: FREED, A. F.; EHRLICH, S. Why do you ask? The function of questions in institutional discourse. New York: Oxford University Press, pp. 42-68, 2010.

HERITAGE, John; ROBINSON, Jeffrey D. "Some" vs "Any" medical issues: encouraging patients to reveal their un met concerns. In: ANTAKI, Charles (ed). Applied Conversation Analysis: Changing Institutional Practices. Basingstoke: PalgraveMacmillan,,p. 15-31, 2011.

HERITAGE, J. Epistemics in action: action formation and territories of knowledge. Research on Language and Social Interaction, v. 45, p. 1-29, 2012.

HUMĂ, B. STOKOE, E. e SIKVELAND, R. O. Persuasive Conduct: Alignment and Resistance in Prospecting 'Cold' Calls. Journal of Language and Social Psichology, 38 (1), pp. 33-60, 2018. 
JAKOBSON, Roman. Lingüística e comunicação. São Paulo, Cultrix, 1969.

JEFFERSON, G. Error correction as an interaction resource. Language in Society, v. 3, n. 2, p. 181-199, 1974.

LODER, L.L.; SALIMEN, P.G. e MÜLLER, M. Noções fundamentais: sequencialidade, adjacência e preferência. In. LODER, L.L E JUNG, N. M. (orgs.) Fala-em-interação social - Introdução à Análise da Conversa Etnometodológica. Campinas, SP: Mercado das letras, 2008.

LYSARDO-DIAS, D. Narrativas de moradores de rua nas mídias sociais. Revista de Estudos da Linguagem, Belo Horizonte, v.26, n.3, p. 989-1013, 2016.

MANDELBAUM, J. Storytelling in conversation. In: SIDNELL, J.; STIVERS, T. (Ed.). The handbook of conversation analysis. Boston: WileyBlackwell, p. 492-507, 2013.

MONTECINO, L.. (Org.). Discurso, pobreza y exclusión en América Latina. Santiago: Editorial Cuarto Propio, 2010, p. 349-364.

MONTEIRO, D. T. A organização sequencial de interacções informais institucionalmente enquadradas. $O$ caso do Atendimento de Acção Social. Dissertação (mestrado) - Universidade Nova de Lisboa. Programa de Pós Graduação em Ciências da Linguagem, Lisboa, 2011.

Monteiro, D. Street-level bureaucracy revisited. Formulating address in social work service encounters. Language and Discourse 6(1), pp. 54-80, 2016.

NATALINO, M. A. C. Estimativa da População em Situação de rua. Texto para discussão. Instituto de Pesquisa Econômica Aplicada: Brasília, 2016.

NONATO, D. do; RAIOL, R. W. G. Invisíveis Sociais: A Negação do Direito à Cidade à População em Situação de Rua. Revista de Direito Urbanístico, Cidade e Alteridade. Curitiba , v. 2 , n. 2 , pp. 81-101, Jul/Dez 2016.

OLIVEIRA, M. C. de. A Organização de Preferência Em Cartas de Pedido de Empresas Estatais Brasileiras. DELTA. Documentação de Estudos em Lingüística Teórica e Aplicada, São Paulo, EDUC, v. 12, n.2, p. 239-254, 1999.

OSTERMANN, A. C. Reifying and defying sisterhood: communities of practice at work at na all-female police station and a feminist crisis intervention center in Brazil. Ann Arbor. 2000. Thesis (Ph.D. Linguistic) Department of Linguistics, University of Michigan, 2000a.

OSTERMANN, A. C. The power of you's: analysis of second-person pronoun variation and alternation in face-to-face interactions in brazilian Portuguese. Paper presented at the NWAV29 - Annual Conference of New Ways of Analyzing Variation in English and other Languages. East Lansing, MI, USA, 2000b. 
OSTERMANN, A. C. A ordem interacional: a organização do fechamento de interações entre profissionais e clientes em instituições de combate à violência contra a mulher. Alfa, São Paulo, 46: 39-54, 2002

OSTERMANN, A. C.; SILVA, C. R. A Formulação em consultas médicas: para além da compreensão mútua entre os interagentes. Caleidoscópio, v. 7, n. 2, p. 97-111, 2009.

OSTERMANN, A. C.; SOUZA, J.. Contribuições da Análise da Conversa para os estudos sobre o cuidado em saúde: reflexões a partir das atribuições feitas por pacientes. Cadernos de Saúde Pública, Rio de Janeiro, v. 25, n. 7, p. 1521-1533, 2009.

OSTERMAN, A. C.; ROSA, D. R. da. Do que não se fala: assuntos tabus e momentos delicados em consultas ginecológicas e obstétricas. In:

OSTERMANN, A. C.; MENEGHEL, S. N. (Org.). Humanização. gênero. poder: contribuições dos estudos de fala em interação para a atenção à saúde. Rio de Janeiro: Fiocruz; Campinas: Mercado de Letras, p. 33-43, 2012.

OSTERMAN, A. C.; ANDRADE, D. N. P; SILVA, J. Análise da Conversa Aplicada em interações entre médicos e pacientes. Veredas atemática, v. 17, n. 2, p 114-135, 2013.

PARDO, M. L. (Org.). El discurso sobre la pobreza en América Latina. 1ed.Santiago: Frasis, 2008, v. , p. 159-174.

POMERANTZ, A. Agreeing and disagreeing with assessments: some features of preferred/dispreferred turn shapes. In: ATKINSON, J. M.; HERITAGE, J. (Org.). Structures of social action. Cambridge: Cambridge University Press, 1984. p.57-101.

POMERANTZ , A.; HERITAGE, J. Preference. In: SIDNELL, J.; STIVERS, $\mathrm{T}$. The handbook of conversation analysis. Boston: Wiley-Blackwell, $\mathrm{p}$. 210-228, 2013.

RAYMOND, G. Grammar and social organization: Yes/no interrogatives and the structure of responding. American Sociological Review, [S.I.], v. 68, n. 6, p. 939-967, 2003.

REED-DANAHAY, D. E. - 'Introduction'. In: REED-DANAHAY, D. E. (ed.) Auto/Ethnography: Rewriting the Self and the Social. Oxford, p. 1-17, 1997.

RESENDE, V. M.; MARCHESE, M. C. São as pessoas pobrezitas de espírito que agudizam a pobreza dos pobres?: análise discursiva crítica de testemunho publicado na revista Cais - o método sincrônico-diacrônico. Cadernos de Linguagem e Sociedade, v. 12, p. 150-178, 2011.

RIBEIRO, B. T. Transcrição e análise: a formatação de entrevistas psiquiátricas. Linguagem, Interação e Cognição, n. 117. Rio de Janeiro: Tempo brasileiro, 1994.

RIZZINI, I.; VALE, J. B. COUTO, R. M. B. Cadernos CIESP - Pesquisa \& Políticas Públicas - Contextos de vulnerabilidade na América Latina, PUC-RIO, n.4. 2017. Disponível em: 
http://www.ciespi.org.br/Publicacoes/Pesquisa-e-politicas-publicas16?from info index=11 Data de acesso: 23/05/2019.

ROBINSON, J. D. Overall structural organization. The handbook of conversation analysis, p. 257-280, 2013.

SACKS, H., "Everyone HastoLie"],. B. Blount\& M. Sanchez (eds), Sociocultural Dimensions of Language Use, New York, Academic Press, 57-79, 1975 [1968].

SACKS, H., SCHEGLOFF, E.; JEFFERSON, G. Sistemática elementar para a organização da tomada de turnos para a conversa. Revista Veredas de Estudos Lingüísticos, v. 7, n. 12, p. 01-67, 2003. Tradução: A Simplest Systematics for the Organization of Turn Taking for Conversation. Language, 50 (4), p. 696-735, 1974. Disponível em: http://www.uffif.br/revistaveredas/files/2009/12/artigo14.pdf

SACKS, H. Lectures on conversation. Oxford: Blackwell, 1992.

SCHNEIDER, B.; REMILLARD, C. Caring about homelessness: how identity work maintains the stigma of homelessness. Text\&Talk; 33(1), pp. 95-112, 2013.

SCHEGLOFF, E. Sequencing in conversational openings. In: GUMPERZ, J.; HYMES, D. (Ed.). Directions in sociolinguistics: the ethnography of communication. New York: Holt, Rinehart and Winston, (1972) 346-404.

SCHEGLOFF, E. A.; SACKS, H. Opening up closings. In: TURNER, R. Ethnomethodology. Harmondsworth: Penguin, p. 233-64, 1974.

SCHEGLOFF, E. A. The routine as achievement. Human Studies, 9, 111 $-151,1986$.

SCHEGLOFF, E. A. Sequencing in conversational openings. American Anthropologist, v.70, n. 6, p. 1075-1095, 1968.

SCHEGLOFF, E. A. Sequence organization in interaction: a primer in conversation analysis. Cambridge: Cambridge University Press, 2007. v. 1.

SEEDHOUSE, P. Classroom interaction: possibilities and impossibilities. ELT Journal, v. 50, n. 1, p. 16-24, 1996.

SEEDHOUSE, $P$. The interactional architecture of the language classroom: a conversation analysis perspective. Malden, MA: Blackwell, 2004.

SEVERINO, J. A. Metodologia do trabalho científico. 23. ed. São Paulo: Cortez, 2007.

SILVA, C. R.; ANDRADE, D. N. P.; OSTERMANN, A. C. Análise da Conversa: Uma breve introdução. ReVEL, [S.I.], v. 11, n. 13, p. 1-21, 2009.

SILVA, M. L. L. da. Trabalho e População em Situações de Rua no Brasil. São Paulo: Cortez, 2009.

SOULET, M. O Trabalho Social Paliativo: entre redução de riscos e integração relativa. Cidades - Comunidades e Territórios, Dez. 2007, n. ${ }^{\circ}$ 15, pp. 11-27. Disponível em: 
http://revistas.rcaap.pt/cct/article/view/9255/6702 Data de acesso: 24/01/2018.

STEENSIG, J.; LARSEN, T. Affiliative and desaffiliative uses of you say questions. Discourse Studies, v. 10, n. 1, p. 113-132, 2008.

STIVERS, T. Participating in decision sabouttreatment: overt parent pressure for antibiotic medication in pediatricen counters. Social Science \& Medicine, v. 54, p. 1111-1130, 2002.

TRUBILHANO, A. G. Rua dos bobos, número zero: as estratégias de sobrevivência de pessoas em situação de rua. São Paulo. 2011. 49f.Trabalho de Conclusão de Curso (Graduação em Psicologia) Centro de ciências biológicas e da saúde. Universidade presbiteriana Mackenzie.

VELHO, G. Observando o familiar. In: Individualismo e cultura: Notas para uma Antropologia da Sociedade Contemporânea. Rio de Janeiro, Zahar Editores, 1981.

VIEIRA, M. A. C.; BEZERRA, E. M. R.; ROSA, C. M. M. População de rua: quem é, como vive, como é vista. 3.ed. São Paulo: Hucitec, 2004.

VINKHUYZEN, E.; SZYMANSKI, M. H. Would You Like to Do it Yourself? Service Requests and Their Non-granting Responses. In: RICHARDS, K; SEEDHOUSE, P. Applying Conversation Analysis. Basingstoke: Palgrave Macmillan, p. 1-15, 2005.

WALKER, E. Making a bid for change: formulations in union/management negotiations. In: FIRTH, Alan (Ed). The discourse of negotiation: studies of language in the work place. Oxford: Pergamon, p. 101-140, 1994. 


\section{ANEXOS}

\section{Convenções de transcrição ${ }^{60}$}

\begin{tabular}{l|l}
\multicolumn{1}{c|}{ CONVENÇÃO } & \\
\hline$(1.8)$ & Pausa (contagem em décimos de segundos) \\
\hline$()$. & $\begin{array}{l}\text { Micropausa (silêncio de menos de 2 décimos de } \\
\text { segundo) }\end{array}$ \\
\hline$=$ & Fala colada \\
\hline$[$ Texto] & Falas sobrepostas \\
\hline, & Entonação contínua \\
\hline$\uparrow$ texto & Entonação ascendente da sílaba \\
\hline$\downarrow$ texto & Entonação descendente da sílaba \\
\hline$\cdot$ & Entonação descendente do turno \\
\hline$?$ & Entonação ascendente do turno \\
\hline- & Marca de interrupção abrupta da fala \\
\hline$:$ & Alongamento de som \\
\hline$>$ Texto< & Fala acelerada \\
\hline$<$ Texto $>$ & Fala mais lenta \\
\hline TEXTO & Fala com volume mais alto \\
\hline${ }^{\circ}$ texto ${ }^{\circ}$ & Fala com volume baixo \\
\hline${ }^{\circ}$ texto ${ }^{\circ \circ}$ & Volume muito baixo \\
\hline Texto & Sílaba, palavra ou som ênfase de som \\
\hline$($ ) & Segmento de fala que não pode ser transcrito \\
\hline (Texto) & Transcrição duvidosa \\
\hline$(($ Texto) $)$ & Comentários da transcritora \\
\hline Hhhh & Riso ou expiração \\
\hline. hhh & Inspiração audível \\
\hline
\end{tabular}

\footnotetext{
${ }^{60}$ Modelo baseado nas propostas de Jefferson (1974).
} 


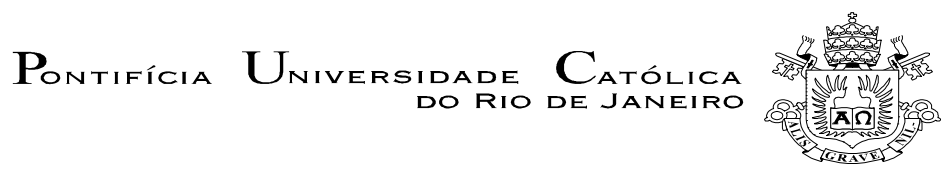

TERMO DE CONSENTIMENTO LIVRE E ESCLARECIDO (TCLE) - ASSISTIDO(A)

Você está sendo convidado (a) para participar, como voluntário (a), do Projeto de Pesquisa sob o título REINSERC̃̃̃O SOCIAL DA POPULAĊ̃̃O EM SITUAÇ̃̃O DE RUA: a atuação da Turma da Sopa de Niterói sob uma perspectiva interacional. Após receber os esclarecimentos e as informações a seguir, no caso de aceitar fazer parte do estudo, este documento deverá ser assinado em duas vias, sendo a primeira via de guarda e confidencialidade da equipe de pesquisa e a segunda via ficará será sua para quaisquer fins. Em caso de recusa, você não será penalizado (a) de forma alguma. Além disso, você poderá interromper sua participação na pesquisa sem sofrer qualquer penalização ou constrangimento.

OBJETIVO DO ESTUDO: Analisar interações entre voluntários da Turma da Sopa de Niterói (TSN) e assistidos. Sendo a comunicação com assistidos realizada pela linguagem, é crucial entendermos como essas interações são construídas pelos participantes da conversa, isto é, como os assistidos recebem atendimento dos membros da TSN e como estes prestam assistência ao morador em situação de rua ou vulnerabilidade social.

PROCEDIMENTO DO ESTUDO: Se você decidir integrar este estudo, algumas interações suas com voluntário(s) da TSN serão gravadas e, caso você queira, participará de uma entrevista com a pesquisadora principal deste estudo.

GRAVAÇÃO EM ÁUDIO: Todas as interações/entrevistas serão gravadas em áudio. As gravações serão utilizadas para estudos acadêmicos, mas serão marcadas com um pseudônimo de identificação, durante a transcrição dos dados, para que seu nome não seja utilizado. Se você não quiser ter sua fala gravada em áudio, você não poderá participar deste estudo.

RISCOS: Você pode achar que determinadas perguntas incomodam a você. Mas, você pode escolher não responder quaisquer perguntas que o façam sentir-se desconfortável.

BENEFÍCIOS: Sua participação será de fundamental importância para o desenvolvimento deste estudo, pois, através da análise da interação entre assistidos e voluntários da TSN, poderemos verificar como tornar essa interação mais eficiente.

CONFIDENCIALIDADE: Os dados gerados por esta pesquisa poderão ser utilizados posteriormente em outras pesquisas que a pesquisadora vier a desenvolver, porém, sempre será mantido o anonimato. Garantimos o sigilo e a confidencialidade para a atual pesquisa.

DÚVIDAS E RECLAMAÇõES: Pesquisadora responsável - Carla Mirelle de O. Matos Lisboa, doutoranda do Programa de Pós-Graduação em Estudos da Linguagem da Pontifícia Universidade Católica do Rio de Janeiro, sob a orientação da professora doutora Maria do Carmo Leite de Oliveira. Você poderá entrar em contato com a equipe de pesquisa através do telefone (omitido aqui), e-mail mirellematos@gmail.com ou por meio do telefone (omitido aqui), e-mail: mcleitedeoliveira@gmail.com. 


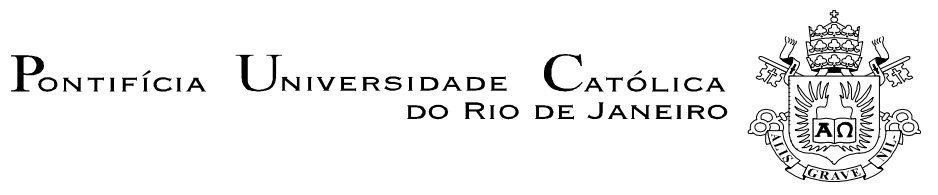

TERMO DE CONSENTIMENTO LIVRE E ESCLARECIDO(TCLE) - VOLUNTÁRIO(A)

Você está sendo convidado (a) para participar, como voluntário (a), do Projeto de Pesquisa sob o título REINSERÇ̃̃O SOCIAL DA POPULAÇ̃̃O EM SITUAČ̃̃O DE RUA: a atuação da Turma da Sopa de Niterói sob uma perspectiva interacional. Após receber os esclarecimentos e as informações a seguir, no caso de aceitar fazer parte do estudo, este documento deverá ser assinado em duas vias, sendo a primeira via de guarda e confidencialidade da equipe de pesquisa e a segunda via ficará será sua para quaisquer fins. Em caso de recusa, você não será penalizado (a) de forma alguma. Além disso, você poderá interromper sua participação na pesquisa sem sofrer qualquer penalização ou constrangimento.

OBJETIVO DO ESTUDO: Analisar interações entre voluntários da Turma da Sopa de Niterói (TSN) e assistidos. Sendo a comunicação com assistidos realizada pela linguagem, é crucial entendermos como essas interações são construídas pelos participantes da conversa, isto é, como os assistidos recebem atendimento dos membros da TSN e como estes prestam assistência ao morador em situação de rua ou vulnerabilidade social.

PROCEDIMENTO DO ESTUDO: Se você decidir integrar este estudo, algumas interações suas com assistido(s) da TSN serão gravadas e, caso você queira, participará de entrevista com a pesquisadora principal deste estudo.

GRAVAÇÃO EM ÁUDIO: Todas as interações/entrevistas serão gravadas em áudio. As gravações serão utilizadas para estudos acadêmicos, mas serão marcadas com um pseudônimo de identificação para que seu nome não seja utilizado. Se você não quiser ter sua fala gravada em áudio, você não poderá participar deste estudo.

RISCOS: Você pode achar que determinadas perguntas incomodam a você. Mas, você pode escolher não responder quaisquer perguntas que o façam sentir-se desconfortável.

BENEFÍCIOS: Sua participação será de fundamental importância para o desenvolvimento deste estudo, pois, através da análise da interação entre assistidos e voluntários da TSN, poderemos verificar como tornar essa interação mais eficiente.

CONFIDENCIALIDADE: Os dados gerados por esta pesquisa poderão ser utilizados posteriormente em outras pesquisas que a pesquisadora vier a desenvolver, porém, sempre será mantido o anonimato. Garantimos o sigilo e a confidencialidade para a atual pesquisa.

DÚVIDAS E RECLAMAÇÕES: Pesquisadora responsável - Carla Mirelle de O. Matos Lisboa, doutoranda do Programa de Pós-Graduação em Estudos da Linguagem da Pontifícia Universidade Católica do Rio de Janeiro, sob a orientação da professora doutora Maria do Carmo Leite de Oliveira. Você poderá entrar em contato com a equipe de pesquisa através do telefone (omitido aqui), e-mail mirellematos@gmail.com ou por meio do telefone (omitido aqui), e-mail: mcleitedeoliveira@gmail.com.

PARTICIPAÇÃO VOLUNTÁRIA: Os participantes não serão remunerados pela participação na pesquisa, portanto sua participação é voluntária.

Eu concordo em participar deste estudo.

Nome: Assinatura:

Data: Assinatura (pesquisadora): 